\title{
East Germans, Refugees, and New Canadians - A Family Migration
}

\author{
by
}

E. Meaghan Harris, B.A.

\author{
A thesis submitted to \\ the Faculty of Graduate Studies and Research \\ in partial fulfilment of \\ the requirements for the degree of
}

Master of Arts

Department of History

Carleton University

Ottawa, Ontario

April 6, 2006

(C) copyright

2006, E. Meaghan Harris 


$\begin{array}{ll}\begin{array}{l}\text { Library and } \\ \text { Archives Canada }\end{array} & \begin{array}{l}\text { Bibliothèque et } \\ \text { Archives Canada }\end{array} \\ \begin{array}{l}\text { Published Heritage } \\ \text { Branch }\end{array} & \begin{array}{l}\text { Direction du } \\ \text { Patrimoine de l'édition }\end{array} \\ \begin{array}{l}\text { 395 Wellington Street } \\ \text { Ottawa ON K1A ON4 }\end{array} & \begin{array}{l}\text { 395, rue Wellington } \\ \text { Ottawa ON K1A ON4 } \\ \text { Canada }\end{array}\end{array}$

Your file Votre référence ISBN: 978-0-494-33735-6 Our file Notre référence ISBN: 978-0-494-33735-6

NOTICE:

The author has granted a nonexclusive license allowing Library and Archives Canada to reproduce, publish, archive, preserve, conserve, communicate to the public by telecommunication or on the Internet, loan, distribute and sell theses worldwide, for commercial or noncommercial purposes, in microform, paper, electronic and/or any other formats.

The author retains copyright ownership and moral rights in this thesis. Neither the thesis nor substantial extracts from it may be printed or otherwise reproduced without the author's permission.
AVIS:

L'auteur a accordé une licence non exclusive permettant à la Bibliothèque et Archives Canada de reproduire, publier, archiver, sauvegarder, conserver, transmettre au public par télécommunication ou par l'Internet, prêter, distribuer et vendre des thèses partout dans le monde, à des fins commerciales ou autres, sur support microforme, papier, électronique et/ou autres formats.

L'auteur conserve la propriété du droit d'auteur et des droits moraux qui protège cette thèse. $\mathrm{Ni}$ la thèse ni des extraits substantiels de celle-ci ne doivent être imprimés ou autrement reproduits sans son autorisation.
In compliance with the Canadian

Privacy Act some supporting forms may have been removed from this thesis.

While these forms may be included in the document page count, their removal does not represent any loss of content from the thesis.
Conformément à la loi canadienne sur la protection de la vie privée, quelques formulaires secondaires ont été enlevés de cette thèse.

Bien que ces formulaires aient inclus dans la pagination, il n'y aura aucun contenu manquant.

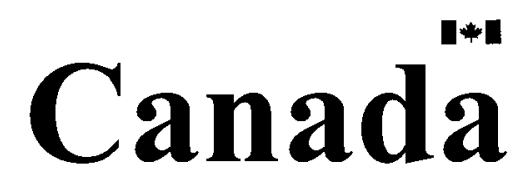




\begin{abstract}
In September 1954, Helma and Reinhard arrived in Canada with their three children in tow, as political refugees. Fourteen months previously, they had fled their home in East Germany due to increasing political pressure, and crossed the border into West Germany where they stayed in refugee camps until they had secured immigration visas. This thesis examines how the migration process impacted this family. Gender, family, and material culture are central themes running throughout this work, as the experiences of the members of this family are considered from the immediate postwar period to their acculturation in Canada in the late 1950s. Paramount to this study is a collection of letters which Helma and Reinhard wrote to their respective families throughout the migration process. This correspondence provides a contemporary account of how migration was experienced, as it was portrayed to loved ones. Furthermore, this study also relies upon the oral testimony of Helma and her daughter Beata. Helma's oral narrative gives this thesis a particularly gendered perspective; moreover, it brings issues of memory and self-identity into discussion. Consistently, the sources emphasize the importance that family played in their lives, as they left their home for a new land, and began again in Canada. This thesis provides an account of postwar East German refugee immigration and it offers insight into the values, anxieties and joys of the postwar immigrant family as they experienced migration first-hand.
\end{abstract}




\section{Acknowledgments}

First and foremost, this thesis is dedicated to 'Shreddie' Harris. As an editor, counselor, friend, but most of all, an unceasing source of motherly support, she is unmatched. Without her, this thesis could not have been completed.

In my 'translators' Onkel Bob and Tante Inge Harris, I found not only inexpensive translation and first hand German-Canadian experience, but much love and encouragement.

With the history crew-Lis, Kristy, Emily, Karen, Mike, Will, and Dr. 'Matt' Anthrax - I found real meaning for my two years at Carleton. In future years I imagine that our friendship (developed over many a night in pubs throughout Ottawa) will be what I remember most about this degree.

Deep thanks go to my supervisor, Marilyn Barber, who patiently helped me revise, revisit, and revise again chapter upon chapter. Despite personal hardship, she gave valuable suggestions, ideas and advice; in moments of poor morale, she encouraged me to persevere while keeping my own standards high. Her limitless experience made this thesis into something important. The mistakes contained in the following manuscript, of course, are mine alone.

I received a great deal of help from faculty in the department not directly involved with this thesis. Jennifer Evans provided an important source of encouragement throughout the writing process. I am ever grateful for her open door and the wisdom and kind words I found in her office. In addition, Joan White, the history graduate secretary, was an invaluable source of knowledge, useful tips, and never-ending patience.

Lastly, I would like to thank Helma Kroll and Beata Myhill. Without their story this thesis would not exist. I hope they find that the trust they placed in me to represent their family history was not misplaced. 


\section{Table of Contents}

\section{Page}

Abstract

ii

Acknowledgements

Table of Contents iv

Chapter One: Uncovering a Story 1

Chapter Two: The War, the Russians, and the Noose 42

Chapter Three: Crowded Waiting Rooms 104

Chapter Four: A House and Home 159

$\begin{array}{ll}\text { Conclusion } & 221\end{array}$

Appendix: Lost in Translation $\quad 230$

$\begin{array}{ll}\text { Bibliography } & 248\end{array}$ 


\section{Chapter One: Uncovering a Story}

Introducing the Krolls

In September 1954, Reinhard and Helma Kroll left their "old homeland behind with scarcely a backward glance."' The Krolls had fled East Germany due to political pressures from the Communist government, and, after a fourteen month wait in a West German refugee camp, they finally gained admission to Canada as political refugees. With their three children in tow, the Krolls' passage across the Atlantic symbolized a rupture between the old life and the new. Leaving behind the austerity and repression emblematic of the German Democratic Republic, the Krolls looked forward to setting up house in the peace and opportunity embodied by postwar Canada.

I first met the Krolls indirectly, through two volumes of letters that Helma and Reinhard had written to their respective parents in Germany. Translated into English, this collection presents letters written primarily between 1953 and 1958. Though these letters constitute the bulk of the collection, there is also a sample of correspondence from Helma to her mother and grandmother during the Soviet occupation, between 1945 and 1946. In addition, a memoir-like summary of Helma and Reinhard's life from 1945 to 1953 is attached, and is joined by a running commentary (throughout the collection) written by Helma-brief notes which help to clarify the subject matter. Altogether, this vast series of letters and its brief memoir entry total 187 typed pages; they provide compelling reading material, and moreover, serve as a rich original source from which to write my Master's thesis.

\footnotetext{
${ }^{1}$ Kroll Collection, 27.9.1954, Centre for Canadian-Russian Relations, Volume II, i.
} 
Twentieth century letter collections such as the Krolls' are a relative rarity for historians. ${ }^{2}$ The dearth has been explained by a diminishment in letter production produced by advances in communication; however, a more likely rationale is given by Alistair Thomson. He states that with the easy accessibility of oral testimony, historians often neglect to seek out written documentation such as letters and memoirs; when they are discovered, it is often by coincidence through the oral interviews. ${ }^{3}$ The unearthing of the Kroll collection and oral testimony is in stark contrast to the latter scenario. It occurred more within the procedure noted by Stephen Fender, who maintains that letters survive and are made 'public' only when a potential donor has sufficient interest in them and realizes their value. ${ }^{4}$ For years, the Kroll collection existed within the private sphere, under the watch of the family's 'female archivist,' who not only kept the letters, but compiled, translated and edited them as well. ${ }^{5}$ Helma Kroll's intention was that the letters should transmit the family history to the next generation. ${ }^{6}$ It was only through the influence of her daughter that the letters were brought forward; Beate Myhill wanted to

\footnotetext{
${ }^{2}$ It should be noted however, that with the passing of time, more twentieth century letter collections are surfacing, and thus so are the publications about them. See for example The First Dutch Settlement in Alberta: Letters from the Pioneer Years, 1903-14. Donald Sinnema, ed. (Calgary: University of Calgary Press, 2005).

${ }^{3}$ Olga Kenyon, 800 Years of Women's Letters. (Boston: Faber and Faber Inc, 1992), p.xvii; Alistair Thomson "Moving Stories: Oral History and Migration Studies" Oral History, 27, no.1 (Spring 1999): 26. ${ }^{4}$ Stephen Fender, Sea Changes: British Emigration \& American Literature (Cambridge: University of Cambridge, 1992), p.19.

${ }^{5}$ Margaret Conrad stresses that women typically take the prescribed role of the family 'archivist,' holding on to personal testimony, such as letters and diaries, sometimes for generations, until their value is realized. Margaret Conrad, "Recording Angels: The Private Chronicles of Women from the Maritime Provinces of Canada, 1750-1950" (Ottawa: CRIA/ICRAF, 1982), p.3.

${ }^{6}$ Though Alistair Thomson cites this as one reason behind oral testimony he states that this also holds true for other forms of personal testimony such as letters. Thomson, Oral History, 27, no. 1(Spring 1999): 26. Thomson also points out that family immigrant stories often become an important part of family memory/identity. Thomson, Oral History, 27, no.1 (Spring 1999): 31.
} 
ensure their safekeeping, and moreover, she was aware of their potential contribution to academic scholarship. ${ }^{7}$

\section{Methodology}

When I expressed a research interest in the letter collection, Mrs. Kroll was asked by Carleton's History Department if she would be willing to be interviewed. She consented. In the spring of 2005, I was warmly invited to Mrs. Kroll's home, where I sat down with her and her daughter, Beate Myhill. Between June and August, I conducted three interviews with these women over cups of coffee and juice, served with fruit and homemade cookies (for which we later exchanged recipes). During this time, I came to very much like my 'research subjects,' and understood the emphasis which oral historians place upon the need to develop a good relationship with their interviewee(s). The resulting interviews were each approximately $1 \frac{1 / 2}{2}$ hours, and produced fifty-five pages of typed transcript. These interviews further developed my interest in the Krolls' story and then cemented the connection which I felt with them. Moreover, the oral testimony produced from our dialogue was an independent document which could accompany the letter collection as a piece of strong, primary source material.

Angela McCarthy asserts that oral history and immigrant letters make an excellent team: their partnership enables "scholars to unravel the experience of migration from the perspective of its participants, thus allowing a more nuanced interpretation of

\footnotetext{
${ }^{7}$ Interview with Beate Myhill, August 9, 2005. p.15 According to Helbich and Kamphoefner, letter donors are often related to the letters' authors, and are vastly overrepresented on the upper end of age, education, and socio-economic status. Wolfgang Helbich and Walter D. Kamphoefner,"Criteria for Survival: Who Wrote Immigrant Letters, Who Kept Them, and How Representative Are They?" Letters Across Borders: The Epistolary Practices of International Migrants, Bruce S. Elliott, David A. Gerber and Suzanne Sinke, eds.(New York: Palgrave, 2006 (forthcoming))
} 
migration." ${ }^{8}$ Oral history can provide insight into questions resulting from things left unsaid or obscured in contemporary documentation; ${ }^{9}$ immigrant letters can be used to both spark the human memory and corroborate oral testimony. ${ }^{10}$ Immigrant letters and Oral History work in a successful tandem - they buttress each other in providing clues to unsolved mysteries, and giving impetus to new lines of questions. Together, the letter collection, its accompanying memoir, and Helma's oral interview combine to form an extraordinarily rich base from which to conduct a historical study.

\section{THE IMMIGRANT LETTER}

In many respects, the Kroll collection conforms to the traditional function of the immigrant letter, which essentially operated on two levels: interpersonal and introspective. During the eighteenth and nineteenth centuries, the decision to emigrate overseas often meant a permanent separation from one's family and homeland, be it for reasons of distance, money, or political danger. ${ }^{11}$ Written correspondence helped to combat the 'ambiguous loss' of loved ones and the resulting disjuncture that accompanied overseas migration. ${ }^{12}$ According to pioneering studies of immigrant letters, their purpose was to "maintain family solidarity. ${ }^{13}$ David Fitzpatrick calls this their 'consolatory

\footnotetext{
${ }^{8}$ Angela McCarthy, "Personal Letters, Oral Testimony and Scottish Migration to New Zealand in the 1950s: The Case of Lorna Carter," Immigrants and Minorities, 23 no.1 (March 2005): 74.

${ }^{9}$ McCarthy, Immigrants and Minorities, 23 no.1 (March 2005): 59

${ }^{10}$ Richards states that "oral testimony is seriously weakened when it is unconnected with contemporaneous evidence," Eric Richards. "Hearing Voices, An Introduction," Speaking to Immigrants: Oral Testimony and the History of Australian Migration, James A. Hammerton and Eric Richards, eds. (Canberra, 2002), p.10, as cited in McCarthy, Immigrants and Minorities, 23 no.1 (March 2005): 61.

"Pauline Grossenbacher Boss. "The Experience of Immigration For the Mother Left Behind: The Use of Qualitative Feminist Strategies to Analyze Letters from My Swiss Grandmother to My Father," Marriage and Family Review, 19 (1993): 366.

${ }^{12}$ Boss. Marriage and Family Review, 19 (1993): 366.

${ }^{13}$ William I. Thomas and Florian Znaniecki. The Polish Peasant in Europe and America. (New York:

Dover Publications, 1958), p.303.
} 
function,' for the letter served to reassure the recipient that the family was still unified. ${ }^{14}$ For the immigrant, where distance was great, letter-writing functioned to maintain close emotional proximity between loved ones, and thus provided a sense of safety and continuance when the surrounding environment was in flux. ${ }^{15}$ As David Gerber states, immigrant letters were "not principally about documenting the world, but instead about reconfiguring a personal relationship rendered vulnerable by long-distance, long-term separation." ${ }^{\prime 16}$ Letter-writing provided an opportunity for relationship growth (or at least prevented its severance), and maintained ties to the greater homeland so long as correspondence continued. ${ }^{17}$ Furthermore, it allowed the immigrant to simultaneously look backwards and forwards, providing the immigrant with a psychological space 'in between' the old home and the new. ${ }^{18}$

The vital connection between self and the immigrant letter is a modern interpretation which has been heavily influenced by the social sciences. ${ }^{19}$ Writtencorrespondence grounded one to the past through old relationships, familiar names and

\footnotetext{
${ }^{14}$ David Fitzpatrick, “'Oceans of Consolation' Letters and Irish Immigration to Australasia," Visible Immigrants, Eric Richards, Richard Reid, David Fitzpatrick, eds. (Canberra: Department of History and the Centre for Immigration and Multicultural Studies, Research School of Social Sciences, Australian National University), 52.

${ }^{15}$ Dirk Hoerder, Creating Societies: Immigrant Lives in Canada. (Montreal: McGill-Queen's University Press, 1999), p.18.

${ }^{16}$ David A. Gerber. "Epistolary Masquerades: Acts of Deceiving and Withholding in Immigrant Letters," Letters Across Borders: The Epistolary Practices of International Migrants, Bruce S. Elliot, David A. Gerber and Suzanne Sinke, eds. (New York: Palgrave, 2006 (forthcoming))

${ }^{17}$ Boss, Marriage and Family Review, 19(1993): 372.

18 "Introduction," Letters Across Borders: The Epistolary Practices of International Migrants. Bruce S. Elliot, David A. Gerber and Suzanne Sinke, eds. (New York: Palgrave, 2006 (forthcoming)). Transnationalism is a recent concept which has been thought mainly to apply to late twentieth century migrants. Gerber challenges this notion, believing that earlier immigrants functioned simultaneously both in the homeland and new world. This can be interpreted both at an emotional and material level. See Gerber's article "Forming A Transnational Perspective." For an interdisciplinary examination of transnationalism in its 'modern context', see the text Towards A Transnational Perspective on Migration: Race, Class, Ethnicity and Nationalism Reconsidered. Vol 645. Nina Glick Schiler, Linda Basch, and Cristina BlancSzanton, eds. (New York: New York Academy of Sciences, 1992)

${ }^{19}$ For an account of immigrant letter historiography, see "Introduction," Letters Across Borders: The Epistolary Practices of International Migrants.
} 
places, thus securing the immigrant's sense of 'true self' through their personal history and old connections. Recent scholarship recognizes that the act of writing played a vital role in the dynamic process of identity construction, or the 'larger identity project. ${ }^{20}$ Over time, letter-writing was a mirror of self-reflection through which one could negotiate an identity that was in constant flux. It changed not only through migration, but also through the big events of life: marriage, childbirth, sickness and death. ${ }^{21}$ In writing to loved ones, the act of composing and creating a narrative helped immigrants make sense of their new life and their place in it. ${ }^{22}$ In this respect, written correspondence can be considered a tool to cope with change: it imparted a degree of continuity both through a connection with others and with one's own self, providing some relief from uncertainty, and facilitate personal growth. ${ }^{23}$

Beyond the emotional plane, immigrant letters were written for more explicit motives: they reassured family of one's well-being, justified the decision to leave home, encouraged or discouraged others' emigration, taught future emigrants how to adapt, and asked for money or material goods. ${ }^{24}$ Modern audiences are often surprised by what is included and excluded in letters' content: "so-called 'important events' are reduced to rumors and abstractions. Wars, revolutions, depressions and elections are sometimes

\footnotetext{
${ }^{20}$ David A. Gerber "Ethnic Identification and the Project of Individual Identity: The Life of Mary Ann Wodrow Archbald (1768-1840) of Little Cumbrae Island, Scotland and Auriesville, New York," Immigrants and Minorities 17 no.2 (July 1998): 12, 17.

${ }^{21}$ Gerber. Immigrants and Minorities 17, no.2 (July 1998): 12 . Gerber's article argues that ethnic identification, though an aspect to one's self-identity, was not its basis. Ethnicity was only one small part of ones self-identity which letters could help maintain.

${ }^{22}$ Kathleen A. Dehaan. "'Wooden Shoes and Mantle Clocks': Letter Writing as a Rhetorical Forum for the Transforming Immigrant Identity," Alternative Rhetorics: Challenges to the Rhetorical Tradition. Laura Gray-Rosendale, Sibylle Gruber, eds. (Albany: State University of New York Press, 2001), p. 55.

${ }^{23}$ David A. Gerber, "Forming a Transnational Narrative: New Perspectives on European Migrations to the United States," The History Teacher 35, no. 1 (2001) 26.

24 McCarthy, Immigrants and Minorities. 23, no.1 (March 2005): 63; David Gerber, "The Immigrant Letter between Positivism and Populism: The Uses of Immigrant Personal Correspondence in TwentiethCentury American Scholarship," The Journal of American Ethnic History. 19, no.4 (Summer 1997): 3.
} 
mentioned but are rarely described as directly related to the lives of our chroniclers." ${ }^{25}$ Besides the big personal events in one's life such as marriage, childbirth, illness and death, letters discuss in detail the stresses of every day life: employment, earnings, purchasing power, prices, leisure activities, food, drink and clothing. ${ }^{26}$ What is said in a letter is dependent upon a variety of factors. The content and tone of correspondence between women, men, siblings, friends, or a parent and child will vary accordingly, and will be affected by an author's personality, gender, education, socio-economic status, relationship with the recipient, and history. ${ }^{27}$ Nevertheless, written correspondence essentially describes the same thing: 'the texture' of daily life. ${ }^{28} \mathrm{~A}$ focus on the 'everyday' is a far departure from what one examines in a more traditional political history. It is this depiction of the often difficult-to-find-'ordinary,' that is one of the most significant contributions of migrant letters-particularly as it relates to women. ${ }^{29}$

According to Lincoln Schuster, "Letters remind us that history was once real life. ${ }^{30}$ Primary sources such as written correspondence "are the human fires that smolder underneath the footnotes," which awaken our senses to the past. ${ }^{31}$ The immigrant letter has been used as a source by historians throughout the twentieth century; however, its utilization has changed. Historians now approach it from different perspectives;

\footnotetext{
25 "Introduction" No Place Like Home: Diaries and letters of Nova Scotia Women 1771-1938. Margaret Conrad, Toni Laidlaw, and Donna Smyth, eds. (Halifax: Formac Publishing Company Limited, 1988 ), 3. ${ }^{26}$ News From the Land of Freedom: German Immigrants Write Home. Walter D. Kamphoefner, Wolfgang Helbich, Ulrike Sommer, eds. Susan Carter Vogel, trans. (Ithaca: Cornell University Press, 1991), p.31.

${ }^{27}$ Hoerder, p.17; Kamphoefner et al., p.30.

${ }^{28}$ Introduction" in No Place Like Home, p.2. Conrad, Laidlaw and Smyth refer particularly to femaleauthored letters in this instance; I would suggest however, though there is a degree of difference between letters authored by the different genders, this remark generally holds true for both.

${ }^{29}$ Here one can see the influence of the 'new' Social history.

${ }^{30}$ M. Lincoln Schuster, ed. A Treasury of the World's Great Letters: From Ancient Days to Our Own Time. (New York: Simon \& Schuster, 1940), p. xli, as cited by Olga Kenyon, in Women's Voices: Their Lives and Loves Through Two Thousand Years of Letters. London: Constable, 1995. (inlay of book)

${ }^{31}$ Lloyd Husvedt, Immigrant Letters and Diaries," The Prairie Frontier, Sandra Looney, Arthur R. Huseboe, nd Geoffrey Hunt, eds. (Sioux Falls: South Dakota, 1984), pp.48, 51, as cited by Gerber, The Journal of American Ethnic History 16, no.4 (Summer 1997), 16.
} 
consequently, its contribution to history has been altered. The most notable example is within migration history; according to David Gerber, the immigrant letter has driven it from a policy and social welfare-based field towards one more inclusive and peopleoriented. ${ }^{32}$ Initially, Historians used letters for statistical purposes, such as immigrant demographics. ${ }^{33}$ This 'reading' was eclipsed by a more qualitative analysis that accrued value from what the letters said; these letters continue to exist in large, edited collections, which form or challenge ideas about the patterns and processes of migration and adaptation through broad themes. ${ }^{34}$ They treat letters as the immigrants' true, unmitigated voices, interpreting through content and editing out that which they might deem 'irrelevant' —-standard greetings, salutations, personal inquiries, condolences, endearments, discussion of food, prices, references to other immigrants and the like. ${ }^{35}$ Though this remains a common approach to immigrant letters, recent trends have taken this analysis further, beyond the concrete to a more ethereal level. The immigrant letter has become the object of study itself, as opposed to simply a source. ${ }^{36}$ Influenced by postmodern literary theory, it is now regarded by some as "a literary genre and a cultural institution," providing both "information and revelation. ${ }^{37}$ Such an approach broadens analysis beyond the narrow confines of content, combining "factual content, revelation of mentality, literary form, cultural significance or family function." ${ }^{, 38}$ Studies using this

\footnotetext{
${ }^{32}$ Gerber, The Journal of American Ethnic History. 16, no.4 (Summer 1997):13.

${ }^{33}$ Niels Peter Stilling "The Significance of the Private Letter in Immigration History" in The Bridge: Journal of the Danish American Heritage Society. 15, no. 2 (1992): 35-50. 35

${ }^{34}$ Stilling, p. 36; Irish Immigrants in the Land of Canaan: Letters and Memoirs from Colonial and Revolutionary America, 1675-1815. Kerby A. Miller, Arnold Schrier, Bruce D. Boling, David N. Doyle, eds. and writers. Oxford: Oxford University Press, 2003. 9.

35 "Introduction," Elliot et al. 10; Fitzpatrick 48; Gerber The Journal of American Ethnic History. 16, no.4 (Summer 1997): 19.

${ }^{36}$ Elliot et al, "Introduction,"Letters Across Borders, p.11.

${ }^{37}$ Fitzpatrick, Visible Migrants, 80.

${ }^{38}$ Fitzpatrick, Visible Migrants, 56.
} 
type of analysis tend to edit out less material, and let the letters speak for themselves. ${ }^{39}$

Recent research, such as that conducted by David Gerber, even examines the significance of what remains unsaid or omitted. Silence is an important aspect of migrant communication, and a historian's role is not to 'fill in' the missing blanks, but to recognize them. ${ }^{40}$

While social historians have used and continue to use letters to make generalizations about immigrants, it is the individual voice contained within the immigrant letter which is most beneficial, for it imparts the ability to observe the individual immigrant as opposed to immigrants en masse. ${ }^{41}$ An examination on a microscale allows one to focus on the personal aspects of migration: motivations, ambitions, challenges and strategies. ${ }^{42}$ As Angela McCarthy states, "the major benefit of emigration correspondence is in illuminating quite vividly and emotionally the varied migration experiences of individuals. ${ }^{, 43}$ It is the subjective, firsthand, contemporary account, which, when compared with other letters, demonstrates the plurality of migration experiences rather than one grand narrative. ${ }^{44}$ Besides diaries, immigrant letters are the only contemporary lens which an audience has to view the individual immigration process as it happened. ${ }^{45}$ Admittedly, the epistolary source has faced criticism on grounds of

\footnotetext{
${ }^{39}$ Conrad et al., No Place Like Home, p. 2.

${ }^{40}$ Gerber, Letters Across Borders: The Epistolary Practices of International Migrants, 10-11. Gerber believes that silence or the omitance of information was often an act of faithfulness towards loved ones. By keeping family ignorant of a migrant's financial, marital, and health woes, they were being protected. ${ }^{41}$ One Family, Two Worlds: An Italian Family's Correspondence Across the Atlantic, 1901-1922. Edited with Introduction by Samuel L. Baily and Franco Ramella. Translated by John Lenaghan. (New Brunswick: Rutgers University Pres, 1988), p.1.

${ }^{42}$ Baily and Ramella, p.2.

${ }^{43}$ McCarthy, Immigrants and Minorities 23, no.1 (March 2005): 69.

${ }^{44}$ Historians such as John Bodnar have stressed "that not everyone faced identical experiences." Bodnar, The Transplanted: A History of Immigrants in Urban America. (Bloomington: Indiana University Press, 1985), p. xvi

${ }^{45}$ Autobiographies or memoirs arguably fit into this category as well, though they are written in retrospect and thus are affected by memory and the passage of time. Kamphoefner et al, p.32.
} 
authenticity, bias, authorship, and representation. ${ }^{46}$ To a large extent, such accusations can be mitigated by supplementary research, statistical data, careful reading, and the validation of other sources. The editing, translation, and presentation of letters can all prove challenging to those using them as a central source. However, given that all historical sources are inherently flawed, such obstacles need not divest the immigrant letter of its value. It simply must be treated within its limits, and used for its advantages.

\section{Relating to the Krolls}

The Kroll letter collection has undergone a series of transitions. Initially, the letters were handwritten in German; in 1991, in order to facilitate her family reading the letters (German script is difficult to decipher), Helma transcribed them, inserting a memoir and commentary in the process. In 2001, Helma further edited the collection and translated it into English. This second edition is the source on which I base my analysis. The challenge in using the Krolls' letters and taking them at 'face value' is compounded by translation and editing. The German and English collections are not identical; however, because of my insufficient German, a complete analysis of their discrepancies is not possible. Nevertheless, Appendix A has been included to offer some discussion of my response to this challenge.

The editing of the letters results in an additional and unforeseen complication, however, for it encroaches upon this thesis'sother central source. Helma's oral testimony is greatly valued-particularly since it offers the rare opportunity for the historian to question and have epistolary content clarified; nonetheless, when one accounts for the

\footnotetext{
${ }^{46}$ See Baily and Ramella, p.3; Elliot et al., "Introduction," Letters Across Borders: The Epistolary Practices of International Migrants; Conrad et al., No Place Like Home, pp. 4, 299; and Wolfgang Helbich and Walter D. Kamphoefner, Letters Across Borders: The Epistolary Practices of International Migrants, for information regarding authenticity, representation and authorship.
} 
importance of memory in a discussion of oral history, Helma's testimony was given a sort of 'false start. ${ }^{47}$ Though oral historians such as Sherna Gluck suggest that objects like papers and photos be used to trigger one's memory, she cautions the historian to be prepared with a tape recorder, for it "could be a lost gem were we not to record it when the memory spontaneously surfaced." 48 By transcribing, translating and editing the letters years prior to her oral interview, Helma's memory was sparked with no verifiable witnesses. She transcribed the letters initially (from German to German) in 1991; at which time she admits that "there were quite a lot of things I didn't remember;" reading the letters decades 'after the fact' attuned her memory to those events about which the letters made mention. ${ }^{49}$ This development is very significant when one considers Helma's testimony, particularly in a discussion of how her memory has negotiated the past. That being said, the stimulus of the letters in no way renders her testimony invalid, for as aforementioned, outside objects can be an advantageous method with which to rouse memories of the past.

\section{ORAL HISTORY}

Oral history is not a source, but a collaborative process which produces source material. ${ }^{50}$ As Paul Thompson states, "Oral evidence, by transforming the 'objects' of study into 'subjects,' makes for a history which is not just richer, more vivid and heartrending, but truer." ${ }^{51}$ Moreover, it not only uncovers new information, but it gives voice to individuals who would likely otherwise remain unheard.

\footnotetext{
${ }^{47}$ Summerfield, p.17;

${ }^{48}$ Sherna Gluck. "What's So Special About Women? Women's Oral History," Frontiers. 2, no. 2 (1977): 9.

${ }^{49}$ Interview with Helma Kroll, August 9, 2005. pp.14-5

${ }^{50}$ Amelia R. Fry, "Suffragist Alice Paul's Memoirs: Pros and Cons of Oral History," Frontiers, 2, no.2, (1977), 85 .

51 Thomson, Oral History. 27, no.1 (Spring 1999), 158.
} 
Oral history is central to many fields, but it is particularly pertinent to migration and women's history. In migration history, it addresses how and why people migrated, family networks, the exchange of information, the building of community institutions, the process of finding work, and experiences of discrimination; it challenges accepted stories within the immigrant community and explores intergenerational relationships; it addresses how the sexes experienced migration differently; and perhaps most importantly, it examines the feelings behind migration: hopes, dreams, fears, and fantasies. ${ }^{52}$ Within women's history, oral history affirms that women's "everyday lives are history," and asks questions of the 'anywoman': queries related to clothing, menstruation, childbirth, sex, birth control, menopause, household work, household economics, women's relationships, the public versus the private, and the like. ${ }^{53}$ Through its ability to focus on the 'ordinary,' oral history listens to the individual voice and thus recognizes the plethora of experiences, moving away from the generalized, collective experience, and unveiling the feelings behind statistics. $^{54}$

Oral history has undergone an evolution. Whereas it was once built upon a strict question-and-answer framework, it now lends itself to a more flexible interview which demands that oral historians "learn to listen." In large part, this challenge for change

\footnotetext{
${ }^{52}$ Paul Thompson, The Voice of the Past: Oral History. (Oxford: Oxford University Press, 1988), 98; Thomson, , Oral History (Spring 1999), 28.; Judy Yung. "Giving Voice to Chinese American Women," Women's Oral History: the Frontiers Reader. Susan H. Armitage, with Patricia Hart and Karen Weathermon, eds. (Lincoln: University of Nebraska Press, 2002); Marilyn Barber. "Hearing Women's Voices: Female Migration to Canada in the Early Twentieth Century," Oral History, 3, no.1 (Spring 2005): 68.

${ }^{53}$ Gluck, Frontiers. 2, no. 2 (1977): 3-4.

${ }^{54}$ McCarthy Immigrants and Minorities. 23, no.1, (March 2005): 71; Thomson, Oral History 27, no. 1 (Spring 1999): 29.

${ }_{55}$ The old framework had a more systematic approach to interviewing; greater numbers of people were interviewed, with less time and detail proportioned to them. More recently, oral historians have started to use fewer testimonies with closer detail. Alistair Thomson cites Francesca Batisti and Alessandro Portelli as example. Thomson, Immigrants and Minorities. 23, no.1 (March 2005), 33; Kathryn Anderson and Dana C.
} 
came from the feminist camp; concerned with issues of power and inequality, it, alongside leading British oral historians, acknowledged that oral history is not a monologue, but rather, a dialogue. ${ }^{56}$ The new frame strongly encourages historians to move away from rigidity within the interview, urging them to embrace - not fearsilence, deviations, and out-of-order narratives. ${ }^{57}$ Interviewers must strive for a fluid interview in which they do not take firm control. This is illustrated with open-ended questions that accord agency to the interviewee in determining the course of the narrative. The result may be a rambling narrative; nonetheless, the interviewer must follow the 'train of memory' until it is concluded, rather than interrupting once an 'adequate' response to the relevant question has been attained. ${ }^{58}$

At the heart of the feminist-inspired frame is a recognition of the relationship between the interviewer and interviewee, an interaction which undoubtedly determines the outcome of the interview. ${ }^{59}$ Irrespective of gender, oral history is not a discourse between two equals: there is clearly a power differential between the two parties. ${ }^{60}$ The interview is a shared experience; the interviewer is a subjective presence, while the interviewee reserves a degree of responsibility. ${ }^{61}$ In essence, such a perspective demands that the interviewer conduct oral history in a different manner: professionalism must be

Jack. "Learning to Listen: Interview Techniques and Analyses," Women's Words: The Feminist Practice of Oral History. Sherna Berger Gluck and Daphne Patai, eds. (New York: Routledge, 1991). 11-26.

${ }^{56}$ Barber, Oral History, 3, no.1 (Spring 2005): 69

${ }^{57}$ Gluck, Frontiers. 2, no. 2 (1977): 9.

${ }^{58}$ Gluck, Frontiers. 2, no. 2 (1977):10.

${ }^{59}$ For example, the interviewee will pick up on verbal and non-verbal cues and adjust their narrative to what they believe interests the interviewer. Gluck, Frontiers. 2, no. 2 (1977), 6; Summerfield, p. 20.

${ }^{60}$ Joan Sangster. "Telling Our Stories: Feminist Debates and the Use of Oral History," Rethinking Canada: The Promise of Women's History. Veronica Strong-Boag, Mona Gleason, Adele Perry, eds. $4^{\text {th }}$ ed. (Toronto: Oxford University Press, 2002), p.226. Because the historian gives the ultimate interpretation of the narrative, she is always in a position of power.

${ }^{61}$ Summerfield, p.24 
maintained, but so must an air of trust and good relations; in order to gain access to personal information, a positive relationship is essential. ${ }^{62}$

Particular concerns arise in relation to women's oral testimony. Feminist historians note that within a male dominated discourse, women have traditionally lacked the ability to frame their stories and thus often remained unheard. ${ }^{63}$ Even when given the opportunity to speak, they were at a loss for language with which to express their intended meaning. ${ }^{64}$ Women's historians have been particularly concerned with providing a frame which allows women 'to speak.' They argue that the 'traditional framework' for oral interviews is intended for male communication, and thus, is not as effective for women. ${ }^{65}$ Men and women communicate differently. Men are assertive, communicate well in a hierarchal atmosphere, and naturally choose to focus on acts, events, and their place in them. On the other hand, women's ideal communicative environment is in a small group, a private setting, and is based upon equality; naturally, they will talk about what they value -feelings and relationships-and will divert attention from themselves. ${ }^{66}$ Moreover, even when women feel comfortable and have the ability to tell their experience, they often doubt the value of their testimony; thus, the interviewer needs to validate the interviewee and affirm that their story is important and worthy of attention. ${ }^{67}$

${ }^{62}$ Gluck, Frontiers. 2, no. 2 (1977):7; Fry Frontiers, 2, no.2 (1977): 86.

${ }^{63}$ Summerfield, p. 28 .

${ }^{64}$ Anderson and Jack, Women's Words: The Feminist Practice of Oral History, 11.

${ }^{65}$ Minister, Women's Words: The Feminist Practice of Oral History, 31. Minister asserts that men and women have been socialized to communicate differently. Joan Sangster refers to Gwen Etter-Lewis, whose research found that women tend to avoid using the first person, understate their own role (and in fact avoid placing themselves in important roles within the narrative), and emphasize family relationships. Sangster, $p$. 223. Men, on the other hand, often use ' $\mathrm{I}$ ', focus on their own agency and initiatives. Isabelle Bertaux-

Wiame as cited by Thompson, Paul 155.

${ }^{66}$ Minister Women's Words: The Feminist Practice of Oral History,30-1.

${ }^{67}$ Gluck, Frontiers. 2, no. 2 (1977):8. 
The interviewee is heavily influenced by the socially constructed variables which surround him or her. ${ }^{68}$ Memories are shaped by class, race, and ethnicity; how we prioritize and perceive past events is framed by the culture in which we exist. ${ }^{69}$ The same holds true for our ability to verbalize experience. Social construction is manifested in both the content and narrative of an oral interview. ${ }^{70}$ Particularly in women's and gender history, it is evident that testimony is guided by the narrator's conceived 'norm. ${ }^{, 71}$ In this respect, it is instructive for historians to observe how interviewees-particularly women-judge themselves against the dominant ideology and 'watch' their own thinking. ${ }^{72}$

The material obtained through oral history is also the subject of debate; yet, its interpretation has progressed, similar to that of the immigrant letter. Initially, oral testimony was taken at face value, i.e.: what fact-oriented information could be gleaned by a 'reliable' witness' account. Increasingly however, oral historians have urged scholars to go beyond content and consider the oral interview a form of literature, in which the narrator's subjectivity, language, and available discourse(s) are addressed. ${ }^{73}$ Moreover, the meaning of language is a cultural construction, and provides the frame for

\footnotetext{
${ }^{68}$ Minister, Women's Words: The Feminist Practice of Oral History,35.

${ }^{69}$ Sangster, p. 223 .

${ }^{70}$ Sangster p. 223.

${ }^{71}$ In a study that examines the self-perception of elderly women about their marriages, Gail Grant points to the social norms of these women's contemporary society against which they judged themselves. She asks are "these the voices of men speaking through women"? ${ }^{71}$ For example, women who had worked with their husbands deemed their marriages as egalitarian, even when in the same breath they also stated that "men always were in charge of the money." In their contemporary culture, it likely did not occur to them that inequality in finances might be interpreted as inequality within the relationship. Gail Grant, "That Was a Woman's Satisfaction: The Significance of Life History for Woman-Centred Research," Canadian Oral History Association, 11 (1991): 33.

${ }^{72}$ Anderson and Jack, Women's Words: The Feminist Practice of Oral History, 21.k defines this process as making meta-statements .

${ }^{73}$ Thompson, p.241.
} 
how we think and act. ${ }^{74}$ The term or phrase used by the narrator might be understood very differently by the interviewer; accordingly, the interviewee should be asked to define and clarify their language in their own words. ${ }^{75}$ (On a very basic level, the same rationale applies to content-a historian can ask for direct clarification about the information provided. ${ }^{76}$ ) Though the subjectivity of oral history is difficult to analyze, it also leads to some of the richest and most meaningful interpretations. ${ }^{77}$ Silences, pauses, reluctance and unwillingness in the narrator are significant and revealing. ${ }^{78}$ Furthermore, when regarded as a whole, the 'narrative logic' of an interview -its formation according to theme, consistency, and contradiction-is informative. ${ }^{79}$

Oral history has had to defend itself from 'traditionalists,' who attacked the human memory, citing its subjectivity and inconsistency as just cause for discarding or minimizing the method's use. ${ }^{80}$ Those who practice oral history recognize its inherent flaws and concede to the ultimate unattainability of 'Experience' or 'Truth'; yet, they maintain that it still must be sought. ${ }^{81}$ Not only does the traditionalist argument ignore the flaws of more traditional sources, but the contestation of memory-about which it is most vocal — has actually produced some of oral history's most meaningful analyses. ${ }^{82}$ Thus,

\footnotetext{
${ }_{75}^{74}$ Summerfield, p.11.

${ }^{75}$ Anderson and Jack, Women's Words: The Feminist Practice of Oral History, 19; Paul Thompson. The Edwardians: The Remaking of British Society. (London: Weidenfeld and Nicolson, 1975), p.6. Thompson asserts that this same issue of language applies all sources, including traditional documentation.

${ }^{76}$ Trevor Lummis, Listening to History, as cited by Valerie Raleigh Yow. Recording Oral History: $A$ Practical Guide for Social Scientists. (London: Sage Publications, 1994), p.10.

${ }^{77}$ Summerfield, p. 17

${ }^{78}$ Jack and Anderson, Women's Words: The Feminist Practice of Oral History, 17.

${ }^{79}$ Anderson and Jack Women's Words: The Feminist Practice of Oral History, 19-22.

${ }^{80}$ These criticisms were particularly strong in the late 1970 s and early $1980 \mathrm{~s}$, before a more literary approach to oral testimony was broached. Thomson, Oral History, 27, no.1 (Spring 1999): 33.

${ }^{81}$ Sangster, Rethinking Canada: The Promise of Women's History, 232. Sangster recognizes it may not be possible to locate women's experience due to language and construct, she urges that historians attempt to do so.

${ }^{82}$ Richard White, Remembering Ahanagran. (New York: Hill and Wang, 1998),p.152 ; Oral history's pioneers acknowledged its weaknesses, but demanded recognition that other historical sources were not free
} 
what was initially cited as a fatal flaw begat what is perhaps oral history's most defining feature, and has largely been proved a fallacious criticism. ${ }^{83}$

The ability to remember is based upon an event's uniqueness, consequentiality (which ties into survival), unexpectedness, and the emotional provocation it produced. ${ }^{84}$ The sharpness of memories is tied to those experiences which were positive or involved conflict or hardship. ${ }^{85}$ Though reminiscence might not follow the historian's ideal chronological form, memory, with all its inconsistencies, must not be discounted. ${ }^{86}$ It has been argued that the elderly, who are often the target of the most criticism, are in reality the most reliable witnesses. The willingness to remember is a key factor in recalling the past. Out of all narrators, the elderly have the least to lose by telling the truth, and their need to be honest increases as they attempt to come to terms with their life. ${ }^{87}$ Just as the composition of 'stories' is a daily practice for every one, the 'life review' is a natural occurrence which comes with old age. ${ }^{88}$ Reminiscence often provides therapeutic

from them either; it is not alone in its construction, bias, and edit-ability. As Thompson points out, traditional written documentation is heavily biased; moreover, in an ironic twist, it is often the case that the 'ideal' archival evidence - censuses, social surveys, birth, marriage and death registrations - is based upon contemporary interviews. Thompson 104. Sangster maintains that because of this, other sources should face the same scrutiny as oral testimony. Sangster 222;

${ }^{83}$ In the early onslaught of criticism, oral historians defended the human memory as best they could. They argued that it is both possible and desirable to verify the information obtained through oral history by crosschecking it with other sources. Fry, Frontiers, 2, no.2 (1977), 3; Judy Yung, "Giving Voice to Chinese American Women," Women's Oral History: The Frontiers Reader. Susan H. Armitage with Patricia Hart and Karen Weathermon, eds. (Lincoln: University of Nebraska Press, 2002), 87, 92; Summerfield, p.230. Supported by psychological studies, they also set to prove that the human memory is not as fallible as one might believe. In fact, though there is a large drop off in human memory after 'the first hour,' there is very little change thereafter, ${ }^{83}$ which is to say that individuals in their sixties would likely have the same memory of an event when they were a young child as would a twenty-year old. Paul Thompson, 111.

${ }^{84}$ Yow, p. 20

${ }^{85}$ Barber, Oral History, 3, no. 1 (Spring 2005):70.

${ }^{86}$ Barber, Oral History, 3, no.1 (Spring 2005):70. Fry, Frontiers, 2, no.2 (1977): 85. Fry points out that where narrators are unable to recalls events, dates, and full names of people, this is a good opportunity to consult written sources.

${ }^{87}$ Yow, pp.18-19

${ }^{88}$ Graham Dawson, [Soldier Heroes, British Adventure Empire and the Imagining of Masculinities. (London: Routledge, 1994)] as cited by Summerfield, p.17. Dawson states that the purpose of the story is to create 'an acceptable self' which one can live with. 
benefits for the elderly who tell their tale; more often than not, the elderly want to tell their story. It is just a case of finding someone who will validate that their experience is worthy of an audience. ${ }^{89}$

Recent scholarship places great emphasis upon the importance of memory in oral history. Alessandro Portelli states that 'untrue statements' can be 'psychologically true;' in other words, a deviation from the 'truth' is sometimes most illuminating. ${ }^{90}$ Issues of identity have become intertwined with those of memory; as White states: "memories are creations; they are a making sense; they are a conscious rewriting in the light of the person who has become and continues to become." ${ }^{91}$ Because memory shapes identity, the reconstruction of the past affects a person's conception of their present self. ${ }^{92}$ In turn, social memory also affects this self-identity. ${ }^{93}$ How one changes their self-perception in order to maintain a positive self-image is important; arguably the memory and its construction is just as worthy of study as the originally sought-out event (or experience) in question. ${ }^{94}$

\footnotetext{
${ }^{89}$ For the elderly, telling their life story can be a gift. It brings self-esteem and pride to a person who feels lost in the present, it can help them mourn those they have lost, it can initiate socialization with others, bring generations together, and help one come to terms with their life, thus easing the aging process. That being said, it can also have negative effects, particularly when recalling painful or traumatic events which had often remained undiscussed. Harriet Wrye and Jacqueline Churilla. "Looking Inward, Looking Backward-Reminiscience and the Life Review," in Women's Oral History: The Frontiers Reader. Susan H. Armitage, with Patricia Hart and Karen Weathermon, eds. (Lincoln: University of Nebraska Press, 2002), 148-150. Also see Summerfeld, pp.17-19,23 Summerfield, p.23.

${ }^{90}$ Alessandro Portelli. "Peculiarities of Oral History," History Workshop Journal 96, no. 12 (Autumn 1981)), 96-107 as cited by Yow, p.22.

${ }^{91}$ White, p.302.

${ }^{92}$ Thomson,, Oral History 27, no.1 (Spring 1999): 35.

${ }^{93}$ Marlene Epp presents an interesting example of social memory and its impact upon oral testimony in her study "The Memory of Violence: Soviet and East European Mennonite Refugees and Rape in the Second World War" in Journal of Women's History 9, no.1 (1997): 62-3. She discusses how social memory shapes narrative; since rape and suffering suggest abandonment by God, this experience is not openly discussed. ${ }^{94}$ Alexander Freund "Immigrants Identities: The Narratives of a German-Canadian Migration" A Chorus of Different Voices: German-Canadian Identities. Angelika E. Sauer and Matthias Zimmer, eds. (New York: Peter Lang, 1998), 204.
} 


\section{Historiography}

Helma and Reinhard Kroll came to Canada bearing a myriad of identities: Germans, East Germans, postwar immigrants, political refugees, worker and dependant, mother and father, husband and wife. This thesis attempts to contextualize the Krolls' experience, particularly from Helma's perspective. The latter half of Chapter One will focus on scholarship pertaining to three general fields: ethnicity, postwar refugee migration, and gender.

\section{Postwar Policy}

The Krolls' immigration experience was predominantly guided by their German identity; however, when one attempts to find literature in which to frame the Krolls' experience as German-Canadians, the stacks are somewhat sparse. Though immigrant groups such as the Ukrainians and Italians have been well-researched, there is a relative shortage of postwar German-Canadian scholarship, which is particularly surprising given that Germans accounted for $15 \%$ of Canadian immigrants during the 1950 's. ${ }^{95}$ This is not to say that German-Canadian scholarship does not exist; nevertheless, in terms of published material, the field is underdeveloped-particularly with regard to postwar East German refugees, and gender.

Much of the existing German-Canadian scholarship treats German immigrants as a homogenous group. As will be further explored, such a broad identification is

\footnotetext{
${ }^{95}$ McLaughlin, K.M. The Germans in Canada.( Ottawa: Canadian Historical Association, 1985), 15. Admittedly, this number does not differentiate between ethnic and national Germans; however, given that the majority of ethnic Germans immigrated during the immediate postwar era, it is relatively safe to assume that this percentage suggests a high concentration of migrants from 'Germany proper.' In particular, Gerhard Bassler, a German-Canadian scholar, has been very vocal about the dearth of German-Canadian scholarship; he theorizes that it is caused by the absence of a strong, unified German-Canadian identity, an identity which was prevented from fully developing due to the postwar Nazi stigma, the strong desire (and ability) of Germans to rapidly assimilate, and Canada's traditional focus on a bi-cultural heritage. Gerhard Bassler. "Problems and Perspectives in German-Canadian Historiography," Annals: German-Canadian Studies. 5 (1985): 1-19.
} 
misleading; although 'German' immigrants may have been treated the same once in Canada, their migration experience varied, mainly by their country of origin. Because 'German' immigrants were treated differently by immigration officials, their demarcation in scholarship is critical. In relation to the Krolls, there are two types of 'classification' which need to be made. The most apparent division is between the ethnic German, or Volksdeutsche -Mennonites, Sudeten Germans, Hutterites, and the Amish— and the German national, or Reichsdeutsche-German-speakers from 'Germany proper." ${ }^{96}$ In postwar Canada, the Volksdeutsche immigrated in large numbers in the late 1940s; in contrast, the Reichsdeutsche were classified as "prohibited enemy aliens" until September 1950, and were therefore barred entry. Many Volksdeutsche arrived in Canada as refugees; for the most part, Reichsdeutsche migration was regarded quite differently, particularly by policy makers. In addition to this larger distinction, an additional line needs to be drawn, which specifically relates to the Krolls. The Reichsdeutsche included Germans from both West and East Germany. Like the Volksdeutsche, those from the East often applied as refugees; they were just refugees of a later time and circumstance.

A fair amount has been written about postwar German immigration, particularly for the years leading up to 1950 , when Germans were removed from the enemy alien list. However, when attempting to contextualize the Krolls' migration story, an impasse is reached: there is virtually nothing which focuses on the East German refugees; in fact, it is a rare occasion that they are even mentioned within longer, more general histories. This holds true for scholarship pertaining to both German-Canadians and Canadian refugee policy. There appears to be a wide gap in this scholarship, between the immediate

\footnotetext{
${ }^{96}$ John C. Walsh. "Re-thinking Ethnic Boundaries: The Negotiation of German-Canadian Ethnic Identities in Ottawa, 1945-75." MA thesis, (University of Ottawa, 1996), 28.
} 
postwar Displaced Persons (DP) crisis and the Hungarian revolution in 1956, both of which led to large waves of immigrants coming to Canada. There is a curious absence regarding the East German refugees, who appeared on the scene in the early 1950s. Though they are prominent in government archival records, they are nearly absent within historical scholarship.

Numerous historians have analyzed Canada's postwar immigration policy and debated the way in which it was formed; within this scholarship, the immediate postwar European refugee crisis has been well-addressed. ${ }^{97}$ Angelika Sauer specifically has focused on DP immigration as it concerned the Volksdeutsche. ${ }^{98}$ The migration of German nationals was officially sanctioned in 1950. Ethnic German immigration began in 1947, aided by various national and international agencies and religious organizations; consequently, it played a large role in opening the door for the Reichsdeutsche. Angelika Sauer has written two articles that place German immigration in the confines of regional affinity, or Volksdeutsche and Reichsdeutsche. In these works, Sauer asks why German nationals (such as the Krolls) were permitted to immigrate. In her attempt to locate an explanation, Sauer addresses different aspects of Canadian policy specifically related to the 'German' case. In “A Matter of Domestic Policy? Canadian Immigration Policy and

\footnotetext{
${ }^{97}$ Michael Marrus, Milda Danys, Gerald Dirks, are only some of the scholars who have focused on the large numbers of Displaced Persons who immigrated to Canada as refugees in the immediate postwar period. Michael Marrus. The Unwanted: European Refugees in the $20^{\text {th }}$ Century. (New York: Oxford University Press, 1985); Milda Danys. DP Lithuanian Immigration to Canada After the Second World War (Toronto: Multicultural History Society of Ontario, 1986); Gerald E. Dirks. Canada's Refugee Policy: Indifference or Opportunism?( Montreal: McGill-Queen's University Press, 1977).

${ }_{98}$ Angelika E. Sauer. "A Matter of Domestic Policy? Canadian Immigration Policy and the Admission of Germans, 1945-50," Canadian Historical Review. 74, no.2 (1993): 226-263; Angelika E. Sauer, "Christian Charity, Government Policy and German Immigration to Canada and Australia, 1947 to 1952," in Immigration and Ethnicity in Canada: selected proceedings of the 22nd Annual Conference of the Association for Canadian Studies held at the Université du Québec à Montréal, 7-9 June 1995. Edited by Anne Laperrière, Varpu Lindström, and Tamara Palmer Seiler (Montréal: Association for Canadian Studies, 1996): 159-180. Also, see her PhD thesis: Angelika Sauer, "The Respectable Course: Canada's Department of External Affairs, the Great Powers, and the 'German Problem,' 1943-1947." PhD thesis. University of Waterloo, 1994.
} 
the Admission of Germans, 1945-50," she examines how policy towards German immigration (primarily Volksdeutche) was affected by international and domestic factors. Although it was generally thought to be dependant upon the domestic sphere, Sauer finds that international pressures - such as the Cold War and calls for humanitarian action-bolstered arguments put forth by the German-Canadian lobby. ${ }^{99}$ Sauer's subsequent work “Christian Charity, Government Policy and German Immigration to Canada and Australia, 1947 to 1952 " continues with this theme; however, its focus is on the “international scramble for labour" amidst relief agencies and religious organizations. ${ }^{100}$ In particular, Sauer looks at the Canadian Christian Council for the Resettlement of Refugees (CCCRR) which facilitated the migration of Volksdeutsche refugees; once such an infrastructure was in place, the CCCRR effectively lobbied and aided the migration of the Reichsdeutsche. ${ }^{101}$ While Sauer acknowledges Canada's economic motivations, she also illustrates how the ethnic community and churches successfully exploited Canada's drive to ensure that Germans were included as immigrants.

\section{Gerald Dirks' text Canada's Refugee Policy: Indifference or Opportunism}

preceded Sauer's article, and provides a broader policy analysis regarding postwar European refugees. ${ }^{102}$ In an effort to discern why Canada chose to accept Displaced Persons, Dirks assesses policy as it was influenced by economic and international

\footnotetext{
${ }^{99}$ Angelika E. Sauer. "A Matter of Domestic Policy? Canadian Immigration Policy and the Admission of Germans, 1945-50," Canadian Historical Review. 74, no.2 (1993): 226-263.

${ }^{100}$ Catherine Panich. Sanctuary? Remembering Postwar Immigration (Sydney: Allen \& Unwin, 1988), 16, as cited in Ibid., 161.

101 Angelika E. Sauer, "Christian Charity, Government Policy and German Immigration to Canada and Australia, 1947 to 1952," in Immigration and Ethnicity in Canada: selected proceedings of the 22nd Annual Conference of the Association for Canadian Studies held at the Université du Québec à Montréal, 7-9 June 1995. Edited by Anne Laperrière, Varpu Lindström, and Tamara Palmer Seiler (Montréal: Association for Canadian Studies, 1996): 159-180.

${ }^{102}$ Gerald E. Dirks. Canada's Refugee Policy: Indifference or Opportunism? (Montreal: McGillQueen's University Press, 1977).
} 
concerns. However, despite Canada's membership in the United Nations Relief and Rehabilitation Administration (UNRRA), the International Refugee Organization (IRO), the United Nations and the Intergovernmental Committee for European Migration (ICEM), Dirks concludes that Canada's acceptance of 'refugees' - as understood by international and Canadian law-was self-serving. Humanitarianism (and even international pressure) came secondary to refugees' economic value. Dirks' analysis of the interdepartmental communications between the Department of Labour, the Department of Citizenship and Immigration, and External Affairs illustrates the competing interests within which the government molded policy. Although not always in conflict with each other, concerns regarding labour, the economy, nation building, international politics and the Canadian reputation, were certainly not aligned.

Donald Avery's Reluctant Host: Canada's Response to Immigrant Workers, 18961994, provides a broader context for Canada's discriminatory policy. ${ }^{103}$ Avery asks a similar question to Dirks — 'What motives shaped Canada's admission of immigrants?'but addresses a broader group. He concludes that economic incentives far out-weighed any humanitarian concerns. Far from being people in need of help, immigrants-refugees included — were regarded as labour fodder. Though there was occasionally a convenient overlap, Canada's actions were opportunistic: beyond meeting an 'acceptable' ethnic and politic standard, immigrants were selected according to their physical health and ability to perform hard labour; their plight, well-being, and overall welfare were by far, secondary.

The Making of the Mosaic: A History of Canadian Immigration Policy by Ninette Kelley and Michael Trebilcock, is a survey text which analyses postwar immigration

\footnotetext{
${ }^{103}$ Donald Avery. Reluctant Host: Canada's Response to Immigrant Workers, 1896-1994. (Toronto: McClelland \& Stewart, 1995).
} 
policy in terms of its economic and political context. While recognizing continued discrimination within policy, it similarly finds that Canada's postwar immigration was primarily determined by economic concerns; big business had great influence upon policy, and immigrants were expected to provide labour and expand upon the existing market. Kelley and Trebilcock assess the various schemes through which postwar refugees and immigrants came, the majority being labour-related. In context of the Krolls' migration, this is helpful for it provides a background to the participation of Church organizations and their contribution to the facilitation of German immigration, both of the refugee Volksdeutsche and the refugee Reichsdeutsche. Moreover, though not with regard to East Germans, this text recognizes the political concerns which were imposed upon immigrants from Eastern Europe. Kelley and Trebilcock portray a policy in motion, but one which had retained its former ideals: refugees were another source of labour with a humanitarian twist; they had to fit within the right demographic - European - and be healthy — able to perform and contribute to the economy - thereby earning membership in Canada's 'community.'

Ronald Schmalz's PhD dissertation, "Former Enemies Come to Canada: Ottawa and the Postwar German Immigration Boom, 1951-1957," is the only scholarship which explicitly focuses on Canadian government policy as it concerned the immigration of 200,000 Germans during the 1950 s. ${ }^{104}$ In approaching German-Canadian migration from the perspective of Ottawa's immigration program and policy, Schmalz concludes that Canada was motivated by economic and political self-interests. Schmalz does not provide an adequate assessment of the East German refugees, but of all scholars, he is the closest

\footnotetext{
${ }^{104}$ Ronald E. Schmalz. "Former Enemies Come to Canada: Ottawa and the Postwar German Immigration Boom, 1951-1957." PhD dissertation. Ottawa: University of Ottawa, 2000, 1.
} 
to doing so. He often lumps the East German refugees with their West German compatriots, which to a degree is logical given Schmalz's deduction that for policy makers, this group of refugees was primarily a source of labor. However, Schmalz misleadingly suggests that East German emigration was relatively unproblematic; though he recognizes security issues, he does not sufficiently incorporate the impact they had upon the immigrant or how this adversely affected immigration. Hence, it is important to address texts which focus on the very real security concerns which existed, and how they were countered (and overcome) by more dominant motives.

In the 1950s, there were substantial complications for those who came to Canada from behind the Iron Curtain. Reg Whitaker and Howard Margolian have analyzed Canadian migration as it relates to the political and security interests of the Canadian government during the Cold War era. In Double Standard: The Secret History of Canadian Immigration, Whitaker finds that during the postwar period, policy was overridden by a new concern: an obsessive Cold War paranoia which permeated the Canadian government. ${ }^{105}$ Whitaker addresses Canada's economic needs but he stresses (international) political motivations--and security. He presents a damning account of Canadian immigration policy; though his argument is rather heavy-handed, it sheds light on officials' concern about those who came (or wanted to come) from behind the Iron Curtain.

Howard Margolian takes a similar, though less critical, approach to policy in his more recent text, Unauthorized entry: The Truth about Nazi War Criminals in Canada,

\footnotetext{
${ }^{105}$ Reg Whitaker. Double Standard: The Secret History of Canadian Immigration. (Toronto: Lester \& Orpen Dennys, 1987).
} 
1946-56. ${ }^{106}$ He approaches Canada's immigration policy-but more specifically, the immigration process - through the security screening which immigrants underwent. Though this focus may seem limiting, it is instructive about the international political climate which permeated the Cold War years. As the threat posed by Communism increased, anxiety regarding former Nazis decreased. Canadian officials attempted to negotiate between these two concerns, the result of which was a very problematic security process; though not explicitly focusing on the East German migrant, Margolian provides the only detailed account of what the screening process was like for refugees such as the Krolls.

\section{German-Canadian Identity}

The 'New History' of the 1960s transformed history, particularly that of immigrants. Previously, the emphasis was placed on policy rather than the migrant experience; immigrants were passive objects rather than active subjects. ${ }^{107}$ The New History' was interested in the experience of immigrants; it gave them agency and recognized that ethnic groups were not one cohesive whole. Influenced by political movements, other disciplines, and new methodologies, it went beyond whiggish lines of immigrant assimilation, and produced a more involved and complex analysis which recognized the importance of ethnicity, class and gender. ${ }^{108}$ Such influence is apparent in the histories of many immigrant groups, but it is reflected little in the available GermanCanadian literature.

\footnotetext{
${ }^{106}$ Howard Margolian. Unauthorized entry: The Truth about Nazi War Criminals in Canada, 1946-56. (Toronto: University of Toronto Press, 2000).

${ }^{107}$ Franca Iacovetta, The Writing of English Canadian Immigrant History. Canada's Ethnic Group Series, Booklet No.22. (Ottawa: The Canadian Historical Association, 1997).

${ }^{108}$ For a discussion of Canadian immigration historiography, see Franca Iacovetta, ibid.; Doug Owram, Canadian History: A Reader's Guide (Toronto: University of Toronto Press, 1994); and Roberto Perin, "Clio as an Ethnic: the Third Force in Canadian Historiography," Canadian Historical Review, 64, no.4 (1983): 441-367.
} 
Most published, German-Canadian scholarship exists in a more traditional formbroad survey texts and community histories which view German immigration and immigrants' contributions idealistically. Although such accounts may be informative, they lack legitimate scholarly analysis. ${ }^{109}$ Such is the case for Fritz Wieden's The TransCanada Alliance of German Canadians: A Study in Culture and Gottlieb Leibbrandt's Little Paradise: The Saga of German Canadians of Waterloo County, Ontario 18001975 - two histories which devote their attention to 'German' immigration on a micro scale. ${ }^{110}$ Though they provide valuable information regarding Germans who settled in Canada during the postwar years, both authors - members of the German-Canadian community - are inclined towards writing positive, laudatory accounts. Significantly, there are very few published texts which address postwar German migration in an academic manner. For the most part, relevant accounts exist in journal articles or unpublished theses. Nonetheless, recent scholarship has begun to reflect some of the changes instituted by the new social history. In particular, the notion of diversity within one ethnic group has become central in discussion of German-Canadians in the postwar era.

Identity is perhaps the most fully explored theme within the recent GermanCanadian historiography. It is recognized even in general histories, such as Bassler's

\footnotetext{
${ }^{109}$ For example, see Wolfgang G. Friedmann, German Immigration into Canada. Contemporary AffairsNo.23. (Toronto: The Ryerson Press, 1951). Dr. Gottlieb Leibbrandt. Little Paradise: The Saga of German Canadians of Waterloo County, Ontario 1800-1975. (Kitchener: Allprint, 1980). K.M. McLaughlin. The Germans in Canada. (Ottawa: Canadian Historical Association, 1985). Rudolph A. Helling, Jack Thiessen, Fritz Wieden, Elizabeth and Kurt Wangenheim, Karl Heeb. A Socio-economic History of GermanCanadians: They, Too, Founded Canada, ed. Bernd Hamm. (Wiesbaden: F. Steiner, 1984). William J.H. Sturhahn. They Came From East and West: A History of Immigration to Canada. (Winnipeg: North American Baptist Immigration and Colonization Society, 1976). Fritz Wieden. The Trans-Canada Alliance of German Canadians: A Study in Culture. (Windsor: Tolle Lege Enterprises, 1985).

${ }^{110}$ Fritz Wieden. The Trans-Canada Alliance of German Canadians: A Study in Culture. Windsor: Tolle Lege Enterprises, 1985 and Dr. Gottlieb Leibbrandt. Little Paradise: The Saga of German Canadians of Waterloo County, Ontario 1800-1975. (Kitchener: Allprint, 1980).
} 
entry on "Germans" in the Encyclopedia of Canada's Peoples. ${ }^{11}$ This competent survey offers an excellent basic understanding of German immigration over a long period of time. Moreover, with specific reference to the postwar era, Bassler crucially recognizes the multiple meanings of 'German'-specifically the distinction between the ethnic German and the German national.

However, the distinction between the ethnic German and German national is only one aspect of identity. A Chorus of Different Voices: German-Canadian Identities, edited by Angelika Sauer and Matthias Zimmer, is dedicated to challenging the singular meaning often assigned to 'German-Canadian.' 112 Likely, this text is in response to older German-Canadian histories which affixed the group with one monolithic identity because of its common language. With thirteen articles by Canada's foremost German-Canadian experts - including Gerhard Bassler, Alexander Freund, Barbara Lorenzkowski and Angelika Sauer - this text recognizes the community's diversity in terms of regional affinity (Volksdeutsche vs. Reichsdeutsche), religion, social background, and gender. It raises important themes with regards to the German-Canadian experience and identity and develops analysis with reference to the state of the current historiography. For example, Sauer's article "The 'Ideal German Canadian': Politics, Academics and the Historiographical Construction of German-Canadian Identity," links the inadequate German-Canadian scholarship to external politics and the identity of the GermanCanadian community. ${ }^{113}$ Whereas during the interwar period there was as an affinity

\footnotetext{
11 "Bassler. "Germans" in Encyclopedia of Canada's Peoples. Edited by Paul Robert Magocsi (Toronto: Published for the Multicultural History Society of Ontario by the University of Toronto Press, 1999): 587612.

${ }^{112}$ A Chorus of Different Voices. Edited by Angelika E. Sauer and Matthias Zimmer. (New York: Peter Lang, 1998).

${ }^{113}$ Angelika E. Sauer, "The 'Ideal German Canadian': Politics, Academics and the Historiographical Construction of German-Canadian Identity” in ibid.: 227-244.
} 
between German politics and the German-Canadian community, in the postwar era a deliberate reconstruction of identity—specifically related to Canada—occurred. Backlash ensuing from the Royal Commission on Bilingualism and Biculturalism in the 1960s (which essentially was the government's assertion of dual national culture) gave credence to immigrant groups other than the French and English, such as the Germans, resulting in a (slow) renewal of German-Canadian scholarship. ${ }^{114}$

Much of the 'new' German-Canadian scholarship exists in unpublished Master's theses and Doctoral dissertations; of these, Ronald Schmalz, John Walsh, Ruth Gumpp and Gisela Forchner are noteworthy. John Walsh's unpublished MA thesis, "Rethinking Ethnic Boundaries: The Negotiation of German-Canadian Ethnic Identities in Ottawa, 1945-75," focuses on the German-Canadian community in the postwar era through a Lutheran church, a fraternal benefit society, and a community newspaper. ${ }^{15}$ Through these institutions Walsh examines how German-Canadian identity was constructed, negotiated, and expressed. This identity was constantly in flux, influenced by the political climate, public opinion, and internal disagreements (for the community consisted of members with different histories and different interests). Primarily, Walsh's work destabilizes the notion of one concrete 'German-Canadian' identity. Community membership was not determined by ethnicity; rather, social interaction and selfidentification with other Germans was required. Nonetheless, the definition and level of

\footnotetext{
${ }^{114}$ Stan Zybala states that it is "a well known fact that Germans are the third strongest ethnic group on the national scene, after French. But not too many people, even experts, are aware of the fact that in four Western provinces Canadians of German origin outnumber by far descendants of French settlers." Zybala also notes the increased German identity in the 1960's, which is reflected in this new multiculturalism, though he is wary of how far it may be taken. Zybala, Stan. "Canadian Germans and their Integration" Working paper given by Stan Zybala at the National Conference of the Canadian Citizenship Branch, October 1963. Ottawa: Department of Citizenship and Immigration, 1963.

115 John C. Walsh. "Rethinking Ethnic Boundaries: The Negotiation of German-Canadian Ethnic Identities in Ottawa, 1945-75." MA thesis. (Ottawa: University of Ottawa, 1996).
} 
active membership varied from one 'German-Canadian' to another. For some, these 'German-Canadian' spaces were a place to meet other Germans, and find aid (emotional and financial) in the settlement process; for others, they provided a loose tie to the homeland, while still helping one keep in touch with their ethno-cultural heritage. Nonetheless, while the community was diverse, Walsh recognizes that it possessed a degree of unity. His chosen locale, with its focus on postwar Ottawa, is particularly serendipitous to the Krolls' analysis. His research supports Helma Krolls' testimony that the community was dispersed, relatively small, and used by 'German-Canadians' to varying degrees; nevertheless, it clearly defines this community's existence, one with which the Krolls had contact, even if very little.

Barbara Lorenzkowski also focuses on Ottawa's German-Canadian community in her article "Making Music - Building Bridges: German-Canadian Identities in the Nation's Capital, 1958-1999;" her focus is a musical choir: Concordia Ottawa. ${ }^{116}$ Though Lorenzkowski offers a gendered analysis of this group, her article is most instructive in its observations about how music linked participants to the past--their memories, homeland, family - and helped them cope with change. Moreover, her study supports the findings made by Walsh and Ruth Gumpp: that the German-Canadian Ottawa 'village' was a community located in an imagined social sphere, as opposed to a tangible, physical space.

Ruth Gumpp's PhD dissertation "Ethnicity and Assimilation. German Postwar Immigrants in Vancouver, 1945-1970," is a study of assimilation and ethnic identity

\footnotetext{
${ }^{116}$ Barbara Lorenzkowksi, "Making Music - Building Bridges: German-Canadian Identities in the Nation's Capital, 1958-1999," in Construire une capitale Ottawa Making a Capital. Edited by Jeff Keshen and Nicole St.Onge. (Ottawa: University of Ottawa Press, 2001): 307-330.
} 
retention. ${ }^{117}$ Gumpp appears to speak to a work by Beatrice Stadler, Language Maintenance and Assimilation: The Case of Selected German-Speaking Immigrants in Vancouver, Canada. ${ }^{118}$ Stadler regards the loss of the German language as emblematic of greater social assimilation, and correlates the retention of language to interest in 'things German.' According to her, as German language use decreases, so wanes the attraction to facets of German culture, such as the German press and German news. On the contrary, Gumpp argues that despite a high degree of integration and assimilation - illustrated by residential patterns, occupational patterns, and language - "ethnic identity and assimilation were ... not mutually exclusive phenomena." 119 Immigrants chose the degree and manner in which they acted out their ethnic identity, or took part in the German-Canadian community. She examines the role that German-Canadian religious, educational and secular institutions played in efforts to maintain such an identity, and finds that despite periods of low participation, an ethnic self-identity persisted, even if it was not always apparent to outside eyes. Gump challenges an older history which judges the process of assimilation according to the integration of males into the wage economy. By recognizing women, the family and the internal values of both, Gump and like-minded historians (who recognize gender) have moved Canadian-German history into a new era.

At this point, we shall turn to the scarce supply of German-Canadian literature which focuses on the experience of women. Gertrud Jaron Lewis appears to have written the first study of female German immigrants in North America with "The German

\footnotetext{
${ }^{117}$ Ruth Gumpp. "Ethnicity and Assimilation. German Postwar Immigrants in Vancouver, 1945-1970." PhD thesis. (Vancouver: University of British Columbia, 1989).

${ }^{118}$ Beatrice Stadler. Language Maintenance and Assimilation The Case of Selected German-Speaking Immigrants in Vancouver, Canada. (Vancouver: CAUTG, 1983).

${ }^{119}$ Gumpp, 166.
} 
Woman Immigrant in Northeastern Ontario." ${ }^{20}$ Her article examines these women as nineteenth century pioneers, domestic servants, and finally (for interests of this paper), postwar immigrant wives and fiancés. Despite the difficulties presented by the article's occasional lapses into German, it is a valuable piece of scholarship due to its reliance on oral testimony and the subsequent discussion which follows. Lewis finds that the attitudes of female German immigrants towards their immigration varied from very positive to regretful. This is especially relevant when considering a life narrative: the way in which a narrator weaves their personal history draws us to consider how one frames and understands their past. It is particularly significant given that Lewis juxtaposes such testimony with results of similar male-based interviews and the considerable discrepancies between such accounts challenge us again to consider the gravity of gender in both oral history and the immigrant experience, as they work together and independently. Her work is instrumental in its pioneering role; though it explores a different type of settlement (the North as opposed to urban centres) it provokes new ways of thinking about the previously silent shadows who accompanied male German migrants.

Gisela Forchner's PhD thesis, published the same year as Lewis' article, is a sociological examination of the postwar German-Canadian family. "Growing Up Canadian: Twelve Case Studies of German Immigrant Families in Alberta" is based upon her interviews with twelve families. Her thesis includes separate lines of questioning for parents and their Canadian-raised children to measure the generational shifts in perception and experience in acculturation. ${ }^{121}$ These case studies add breadth to her in-

\footnotetext{
${ }^{120}$ Lewis states this explicitly in her introduction. Gertrud Jaron Lewis "The German Woman Immigrant in Northeastern Ontario." Annals: German-Canadian Studies 5 (1983): 143-166.

${ }^{121}$ Gisela Forchner "Growing Up Canadian: Twelve Case Studies of German Immigrant Families in Alberta." PhD thesis. (Edmonton: University of Alberta, 1983).
} 
depth discussion of cultural transition and the challenges which are presented to the immigrant family. Her conclusions support those of other scholars: the German-Canadian experience was multifarious in itself, as well as distinct from other ethnic groups. For immigrant children, identity became a negotiation between their parents and the outside Canadian culture; yet, through ritualized behaviour — such as food and holiday traditions - even when language and a national German culture were lost, some form of ethnic identity was retained.

The most significant contemporary historian who studies gendered postwar German-Canadian history is Alexander Freund, who uses oral history as his central source. His MA paper, "Identity in Immigration: Self-Conceptualization and Myth in the Narratives of German Immigrant Women in Vancouver, BC, 1950-1960," and two articles: "Exploring Myths in Women's Narratives: Italian and German Immigrant Women in Vancouver, 1947-1961," and "Immigrants' Identities: The Narratives of a German-Canadian Migration" utilize the testimony of former domestic workers, in an effort to establish their experience as they remember it. ${ }^{122}$ Freund explores the idea of identity construction and memory in relation to immigration - both in respect of these women's departure and adjustment to Canadian life. However, what is arguably the most pivotal aspect to Freund's work is his explicit recognition of female immigrant agency; even in situations where these women might be deemed victimized, through their personal action, and later through the negotiation of their own memory and identity, they

\footnotetext{
${ }^{122}$ Alexander Freund. "Identity in Immigration: Self-Conceptualization and Myth in the Narratives of German Immigrant Women in Vancouver, BC, 1950-60." MA paper. Vancouver: Simon Fraser University, 1994; Alexander Freund and Laura Quilici "Exploring Myths in Women's Narratives: Italian and German Immigrant Women in Vancouver, 1947-1961," BC Studies, 105-106, (Spring/Summer 1995): 159-182; Alexander Freund. "Immigrants' Identities: The Narratives of a German-Canadian Migration" Alexander Freund, in A Chorus of Different Voices: German-Canadian Identities. Edited by Angelika E. Sauer and Matthias Zimmer (New York: Peter Lang, 1998): 187-208.
} 
played a part in their migrant experience as active agents. Freund's work is thus centered on a dual platform: the migration experience itself and the way in which it is recalled by German immigrant women. Furthermore, his comparison of this narration to Italian women, in the co-written article with Laura Quilici, calls for further studies. Through his work, Freund affirms that 'the' immigration experience of German women was distinct from both German men and women of other ethnicities; as such, it deserves attention in the greater scholarship of gendered immigrant history. Unfortunately, Freund's most recent work, Aufbrüche nach dem Zusammenbruch: Die deutsche NordamerikaAuswanderung nach dem Zweiten Weltkrieg, which specifically focuses on the postwar era of German immigration, is unavailable in English. ${ }^{123}$ However, with Freund's stated interest in gender and oral history, and his position as Chair of German-Canadian Studies at the University of Winnipeg, he has the potential to greatly influence the course taken by the German-Canadian historical community, into a more gender-friendly and analytical direction. ${ }^{124}$

\section{Gender, Family \& Women's History}

Though women's and gender history have made an appearance within German-

Canadian history, as Barabara Loreznkowksi notes, their presence is at best minimal. ${ }^{125}$

\footnotetext{
${ }^{123}$ Alexander Freund. Aufbrüche nach dem Zusammenbruch: Die deutsche Nordamerika-Auswanderung nach dem Zweiten Weltkrieg. Göttingen: Vandenhoeck \& Ruprecht Unipress, 2004. The direct translation of this title is Departures after the collapse: The German North America Emigration after the Second World War. The fact that Freund is writing in German supports Gerhard Bassler's assertion that there is a positive correlation between ethnic identity, and the writing of ethnic historical scholarship; this ties into Beattrice Stadler's claim that the retention of language is emblematic of a stronger ethnic identity. Gerhard Bassler. "Problems and Perspectives in German-Canadian Historiography," Annals: German-Canadian Studies. Vol.5 (1985): 1-19. Stadler. Language Maintenance and Assimilation: The Case of Selected GermanSpeaking Immigrants in Vancouver, Canada. Vancouver: CAUTG, 1983, 2.

${ }_{124}$ See Freund's profile, Humanities and Social Sciences Online. $<$ http://www.h-net.org/people/editors/show.cgi?ID=124397> (April 2, 2006)

${ }^{125}$ I had the opportunity of talking with Dr. Lorenzkowski about my research while she was visiting Carleton on February 10, 2005. Lorenzkowski suggested a similar gap existed in the United States as well. Though Alexander Freund has recently published a book along a gendered-German Canadian immigration theme, it is written in German, and at this time is unavailable in English.
} 
Because of this void, my analysis has been heavily influenced by scholarship outside the realms of German-Canadian history; in particular, themes within women's, family, and gender history have been especially informative with regard to the migrant experience of the Krolls.

Franca Iacovetta is arguably Canada's foremost expert with regard to histories which cross boundaries of immigration, gender, and ethnicity. As an author, she has supplied the greatest theoretical framework for this thesis. Iacovetta's classic text Such Hardworking People: Italian Immigrants in Post-war Toronto, examines the inner dimensions of the immigrant family, deconstructing this unit and bringing to the forefront the constant negotiations and shifting dynamics which occurred within it. ${ }^{126}$ Of particular interest is how she addresses the consequences of immigrant women's work within the family: its necessity, its power in granting women more voice, and how it altered selfidentity - both that of the woman and her husband. Though she also addresses the importance of homeownership, language, community and racism, lacovetta more importantly challenges the assumption that immigrant women had no agency; rather, she shows that they employed unique strategies which gave them power in the present and helped their families work towards Canadian 'success.' Iacovetta's most recent work concerns the interaction between the state, receiving society, and immigrant women in the Cold War climate; nonetheless, she continues to portray immigrant women as independent and subject to their own choices, even in response to strong bureaucratic and institutional pressures. ${ }^{127}$

\footnotetext{
${ }^{126}$ Franca Iacovetta. Such Hardworking People: Italian Immigrants in Postwar Toronto (Montreal : McGill-Queen's University Press, 1992).

${ }^{127}$ Recent work by Franca Iacovetta includes Gatekeepers: Reshaping Immigrant and Refugee Lives in Cold War Canada. (Between the Lines, forthcoming); “Making Model Citizens: Gender; Corrupted
} 
Marlene Epp's text Women without Men: Mennonite Refugees of the Second

World War has also has made significant inroads into gendered immigrant history. ${ }^{128}$ Epp addresses the unique experience of Mennonite women, and recognizes that although Mennonite men also faced persecution, endured starvation, and shared the same enemy and future uncertainty as their female counterparts, within this 'shared' ordeal, Mennonite women had to contend with an additional set of circumstances. They were victimized differently during the war due to the Soviet's systematic removal of their men, the experience of wartime violence, rape (and as a result, illegitimate births), and the burden of children while on the run. Furthermore, once they had reached safety by migrating, Mennonite women, particularly those who were single, were received differently from their male counterparts by the Canadian Mennonite community. Traditional gender roles informed how they were treated, and, because of the independence that these women had developed during the prewar years, and the sexual nature of war time trauma, Mennonite women continued to be victimized, separate from men, in the land of 'freedom,' too.

One can infer certain information about the refugee experience from Epp's text, but other works can provide a more thorough account. ${ }^{129}$ Milda Danys' text $D P$

\footnotetext{
Democracy, and Immigrant and Refugee Reception Work in Cold War Canada," In Whose National Security? Canadian State Surveillance and the Creation of Enemies. Edited by Gary Kinsman, Dieter K. Buse, Mercedes Steedman, eds. (Toronto: Between the Lines, 2000); "Recipes for Democracy? Gender, Family and Making." Canadian Woman Studies, 20(2000):12-21.

${ }_{128}$ Marlene Epp. Women Without Men: Mennonite Refugees of the Second World War. Toronto: U of T Press, 2000. Also see Sisters or strangers? Immigrant, Ethnic and Racialized Women in Canadian History. Edited by Marlene Epp, Franca Iacovetta and Frances Swyripa, (Toronto: University of Toronto Press, 2003).

${ }^{129}$ The following works also recognize the divide between the refugee experience versus that of the migrant. Lubomyr Y. Lucik "“This Should Never Be Spoken or Quoted Publicly': Canada's Ukrainians and Their Encounter with the DPs" in Canada's Ukrainians: Negotiating an Identity. Edited by Stella Hryniuk \& Lubomyr Luciuk (Toronto: University of Toronto Press, 1991), 102-122; Ihor Stebelsky "The Resettlement of Ukrainian Refugees in Canada After the Second World War" in Canada's Ukrainians: Negotiating an Identity. Edited by Stella Hryniuk \& Lubomyr Luciuk (Toronto: University of Toronto Press, 1991), pp.123-155; N.F. Dreisziger "The Refugee Experience in Canada and the Evolution of the Hungarian-
} 
Lithuanian Immigration to Canada After the Second World War focuses on the transit camp experience, along lines of gender and Lithuanian (DP) immigration. ${ }^{130}$ Despite the differences between German 'political refugees' and earlier DP's, Danys's inquiry as to what the DP camps were like - a 'purgatory' where illness and uncertainty ran rampantis very applicable to the East German case. The particular attention Danys pays to the refugee's mindset in such an environment is especially relevant, as it is missing in many other migrant accounts. Mona Oikawa's article "Cartographies of Violence: Women, Memory, and the Subject(s) of the "Internment," presents a similar theme to Danys'. ${ }^{131}$ Although she focuses on Canada's internment of Japanese-Canadians during World War Two, her depiction of women, family, and confined space conforms to the postwar Europe experience. Of particular merit is Oikawa's examination of how space is remembered by interned women in relation to raising children, continuing daily routines, and living in close proximity with others.

Memory has an increasingly prominent place in gendered immigrant studies, and is a strong theme throughout this thesis. Though it has been examined in relation to oral testimony and methodology, it is also significant from a historiographical perspective. Approaching the migration experience through tangible 'material' is particularly instructive when combined with oral testimony. Sisters or Strangers? Immigrant, Ethnic and Racialized Women in Canadian History, edited by Marlene Epp, Franca Iacovetta, and Frances Swyripa, provides an excellent starting point from which to think about the

Canadian Community" in Breaking Ground: The 1956 Hungarian Refugee Movement to Canada. Edited by R.H. Keyserlingk (North York, Ont.: York Lane Press, York University, 1993), pp. 65-86

${ }^{130}$ Milda Danys. DP Lithuanian Immigration to Canada After the Second World War (Toronto: Multicultural History Society of Ontario, 1986).

${ }^{131}$ Mona Oikawa. "Cartographies of Violence: Women, Memory, and the Subject(s) of the 'Internment," Race, Space and the Law: Unmapping a White Settler Society, Edited by Sherene H. Razack, (Toronto: Between the Lines, 2002), 74-6. 
female migrant's experience. It is a collection of articles which explores the experiences of different groups of immigrant women and their on-going negotiation of identity and ethnicity within the receiving society. ${ }^{132}$ Its articles vary in theme, but for the most part recognize diversity, female agency, and often cross ethnic and cultural boundaries. Above all, however, they address experience, and as such, incorporate memory as a general source. Of particular interest to me is how this text addresses the relationship between immigrant women and the 'physical,' such as material goods and food.

Though space can be an important trope in the life narratives of refugee women, food and material goods (including a material culture) are even more central. Epp's article "The Semiotics of Zwieback: Feast and Famine in the Narratives of Mennonite Refugee Women" (located in the previous text), and Michelle Langfield's and Pam Maclean's work "'But Pineapple I'm Still A Bit Wary of': Sensory Memories of Jewish Women who Migrated to Australia as Children, 1938-9," study migrant narratives in which food is pivotal to remembered experience. ${ }^{133}$ Donna Gabbacia points out that food is especially important to immigrants in a foreign environment. ${ }^{134}$ For refugees in particular, the experience of going from poverty to abundance was often best symbolized and remembered by what one ate. Historians who study material culture, such as Valerie Korinek and Iacovetta in "Jello-O Salads, One-Stop Shopping, and Maria the

\footnotetext{
${ }^{132}$ Sisters or Strangers? Immigrant, Ethnic and Racialized Women in Canadian History. Edited by Marlene Epp, Franca lacovetta, and Frances Swyripa. (Toronto: University of Toronto Press, 2003).

${ }_{133}$ Marlene Epp. "The Semiotics of Zwieback: Feast and Famine in the Narratives of Mennonite Refugee Women," in Sisters or strangers? Immigrant, Ethnic and Racialized Women in Canadian History. Edited by Marlene Epp, Franca Iacovetta, Frances Swyripa (Toronto: University of Toronto Press, 2003): 314-340. Michelle Langfield and Pam Maclean, "But Pineapple I'm Still A Bit Wary of': Sensory Memories of Jewish Women who Migrated to Australia as Children, 1938-9," Speaking to Immigrants: Oral Testimony and the History of Australian Migration. A. James Hammerton and Eric Richards, eds. (Canberra: History Program and Centre for Immigration and Multicultural Studies, Research School of Social Sciences, The Australian National University, 2002), 93.

${ }^{134}$ Donna R. Gabbaccia, We Are What We Eat: Ethnic Food and the Making of Americans. Cambridge: Harvard University Press, 1998.
} 
Homemaker: The Gender Politics of Food," in addition to Epp's aforementioned article, have repeatedly stressed the abundance with which European immigrants were confronted upon coming to North America. ${ }^{135}$ The availability and selection of clothing, cosmetics, appliances, and technology left vivid impressions upon migrants; however, food, as the source of life and traditional centre of culture and family, remains a dominant 'material' theme in many life narratives.

Memory and immigrant identity have added an important dimension to gendered immigrant studies. In the context of the refugee experience, historians such as Epp have embarked upon new territory: traumatic memory. In "The Memory of Violence: Soviet and East European Mennonite Refugees and Rape in the Second World War" Epp addresses how Mennonite women dealt with the experience of rape ${ }^{136}$ Her discussion of how memory is negotiated - individually and collectively-in response to the social pressures and stigma which existed in the Canadian Mennonite community is significant, particularly in light of the distance which separated the event from the 'actor.' Retrospect brings new 'explanations' to historical experience, because perspective changes over time. Marilyn Barber's article "Hearing Women's Voices: Female Migration to Canada in the Early Twentieth Century" offers an important analysis of how female immigrants

\footnotetext{
${ }^{135}$ Franca Iacovetta and Valerie J. Korinek. "Jello-O Salads, One-Stop Shopping, and Maria the Homemaker: The Gender Politics of Food." In Sisters or strangers? Immigrant, Ethnic and Racialized Women in Canadian History. Edited by Marlene Epp, Franca lacovetta, Frances Swyripa, 190-230. Toronto: University of Toronto Press, 2003.

${ }^{136}$ Marlene Epp, "The Memory of Violence: Soviet and East European Menonite Refugees and Rape in the Second World War," Journal of Women's History 9, no.1(1997): 58-87. Along similar lines is Paula Draper's article "Surviving Their Survival: Women, Memory and the Holocaust;" although she deals with a different group of women, Draper's observation that traumatic experience continue to shape one's life long after the event is telling. Draper, Paula J. "Surviving Their Survival: Women, Memory, and the Holocaust." In Sisters or strangers? Immigrant, Ethnic and Racialized Women in Canadian History. Edited by Marlene Epp, Franca Iacovetta, Frances Swyripa, 399-414. (Toronto: University of Toronto Press, 2003): 399-414.
} 
experienced migration and how they negotiated life in a new place. ${ }^{137}$ Moreover, she examines the way in which women frame their experience: how they shape their life narrative and what this tells us about both their self-conception and contemporary values. Such an approach addresses both the original experience, and the way in which it has been internalized by the key actor. Within the context of German-Canadian history, Alexander Freund, as mentioned previously, is a pioneer in this respect. The themes of gender, migration, memory and oral testimony considered in these works will be central to this thesis.

The next three chapters examine the impact of migration on the Kroll family. Chapter Two "The War, the Russians, and the Noose," is an account of the Krolls' lives between World War Two and 1953. Setting the stage for the entire thesis, it chronicles Helma's experience in particular, highlighting such themes as gender, family, work, and material culture, in the context of a very tumultuous period of German history.

Chapter Three "Crowded Waiting Rooms," documents the Krolls' fourteen month stay in refugee camps. This chapter will analyze the particular challenges the Krolls faced with regards to housing, material goods, work and migration. It will also continue the trope of family, both as it relates to Helma and Reinhard's small family, and to the connection each had with their parents. The latter relationship becomes particularly important, as it forms the basis for the Kroll letter collection.

Chapter Four "A House and Home," chronicles the Krolls' first three years in Canada. It continues an analysis of gender, work and material culture, and also gives attention to the significance of ethnicity in adapting to the new community and country.

${ }^{137}$ Marilyn Barber. "Hearing Women's Voices: Female Migration to Canada in the Early Twentieth Century." Oral History, 3, no. 1(Spring 2005): 68-76. 
This chapter depicts the Krolls' determination, perseverance, and optimism in creating a 'home;' nonetheless, it also depicts the ongoing tie to the homeland, with which contact continued.

This thesis ends with a brief conclusion which integrates the central themes highlighted by this case study. It is my intention that this work not only add to the existing German-Canadian scholarship, but in addition contribute to the understanding of post-war migration, particularly as experienced along gendered lines. This thesis is not a celebration of Helma Kroll's life, but I hope that it does justice to the experience of a woman who was so gracious as to share her story. 


\section{Chapter Two: The War, the Russians, and the Noose}

"They had it much, much harder than I ever had. Really and truly, I had it good."

As a reflective 83 year-old woman, Helma Kroll looks upon her experience in war-torn Germany with a self-deprecating manner. To many Canadians, her experience seems extraordinary -fraught with danger, instability, and the unknown. Yet, for Helma, "the trouble in the whole thing is you get so used to it; what for you is exceptional, for us was ordinary."2 This chapter will examine the 'ordinary' experience of Helma and her family following World War II. As it retraces the important steps in her journey-her post at a girls' work camp, life under the Soviet occupation, her marriage to Reinhard Kroll, and the political factors which compelled them to flee the GDR - it will also assess how she constructs her experience. This passage through time is critical in setting the stage for the Krolls' (specifically Helma's) future mindset in Canada. ${ }^{3}$ In addition, it will provide a basis for understanding their ability to withstand hardship and be resourceful, as well as explain their future preoccupations with stability, material comfort, and most of all, family —including the need to maintain an ongoing connection with loved ones. That being said, the concurrent exploration of memory and the construction of the life narrative is just as important to this study, for it provides an additional layer of understanding

\footnotetext{
${ }^{\mathrm{I}}$ Interview with Helma Kroll, June 8, 2005, pp.2, 4.

${ }^{2}$ Interview with Helma Kroll, June 20, 2005. p. 1.

3 Steven Vertovec and Robin Cohen, 'Introduction,' Vertovec and Cohen, eds, Migration, Diasporas and Transnationalism, (Cheltenham, UK: E. Elgar, 1999), xviii; as cited by Marlene Epp, "The Semiotics of Zwieback: Feast and Famine in the Narratives of Mennonite Refugee Women," in Sisters or Strangers: Immigrant, Ethnic and Racialized Women in Canadian History, edited by Marlene Epp, Franca lacovetta and Frances Swyripa. (Toronto: University of Toronto Press, 2003), 318; Paul J. Draper, "Surviving Their Survival: Women, Memory, and the Holocaust," in Sisters or Strangers: Immigrant, Ethnic and Racialized Women in Canadian History. Edited by Marlene Epp, Franca Iacovetta and Frances Swyripa (Toronto: University of Toronto Press, 2003), 400.
} 
Helma's experience, how she remembers her history, and how this memory affects the story that is about to unfold.

This chapter primarily develops its analysis from Helma's oral testimony and an accompanying memoir she wrote when transcribing and translating the letters (in 1991 and 2001, respectively). Though Helma's lived experience is an invaluable source of historical evidence, it must be recognized that it is also a construction, dependant upon culture, ideology, social values, and her self-conception in both the past and present. The act of remembering, through oral interviews and memoir writing, is a form of the 'life narrative' in which one scripts life to portray experience in a particular manner. As practitioners of women's oral history have stressed, the information ascertained through oral testimony is not merely that of the explicit facts revealed; rather, the narrative form is a sub-layer through which we are offered additional "insight into the social and material framework within which [women] operated, the perceived choices and cultural patterns they faced, and the complex relationship between individual consciousness and culture."4 What Helma remembers, what she chooses to emphasize, and how she 'spins' her story cannot be isolated from the narrative itself. From the very beginning of her testimony various influences act upon her narrative. Perhaps the most central is Helma's inherent optimism which continually minimizes her hardships, despite periods of evident struggle and pain. This unconscious outlook is the most obvious but by no means the only perspective influencing the construction of her life story.

\footnotetext{
${ }^{4}$ Joan Sangster, acknowledging R. Grele, Envelopes of Sound (Chicago: Precedent Publishing, 1975) in "Telling Our Stories: Feminist Debates and the Use of Oral History," Rethinking Canada: The Promise of Women's History. Veronica Strong-Boag, Mona Gleason, Adele Perry, eds. $4^{\text {th }}$ ed. (Toronto: Oxford UP, 2002), p. 222.
} 
Helma was raised in a two-woman household, consisting of her young mother, Eleonore Schmitt, and her grandmother, Eleonore Schmolz. ${ }^{5}$ Helma's mother worked as a secretary and was the household's primary breadwinner, while her grandmother acted as her caregiver. Like many young Germans, Helma was a faithful citizen of Hitler's Third Reich. She was eleven years old when he came to power in 1933, and through her teen years became indoctrinated into Nazi ideology. ${ }^{6}$ Scholars have emphasized the high rate of Nazi success in molding a young generation in their model. ${ }^{7}$ As Helma states, "They had a good way to engage the young people -they understood how to impress them. Very honestly, it was the same with me." ${ }^{\prime 8}$ Helma clearly minimizes her connection with Nazism and steers clear from any sort of ideological tie, which is understandable given her contemporary conception of self and the dominant ideology that the postwar world endorsed - in which Nazism was a recognized evil and one was ostracized for any link to it. Instead, Helma understands her involvement as one of necessity, career opportunism and individual agency. After attending three years of middle school, Helma attended a business school where she was trained in secretarial work. However, at age eighteen, after having worked in an office for two years, she was sent to an "Arbeitsdienst" or labour camp for girls, in the Sudetenland. This was to fulfill her 'community service' to the Fatherland, which by 1939 was an enforced requirement for young Germans of both sexes. ${ }^{9}$ In 1940, Helma was one of 335,972 young women to perform her Year of Duty in

\footnotetext{
${ }^{5}$ Helma's father died when she was four years old.

${ }^{6}$ Ute Frevert. Women in German History From Bourgeois Emancipation to Sexual Liberation. Trans. Stuart McKinnon-Evans in association with Terry Bond and Barbara Norden. (New York: St. Martin's Press, 1986.), p.243.

${ }^{7}$ For example, Frevert, p. 243

${ }^{8}$ Interview with Helma Kroll, June 8, 2005, p. 1.

${ }^{9}$ For men, labour service was compulsory in 1935. It was not enforced for women (between 17 and 25 who were unemployed, or not working full-time in school, vocational training, or on a family farm) until September 1939 when the war had officially begun. Frevert, p.227.
} 
agriculture. ${ }^{10}$ There, with a group of 48 young women who were clothed, fed, and given 20 cents of pocket money per day by the German Government, ${ }^{11}$ Helma and her fellow 'Maidens' helped the farmer's wife with her daily work in and outside the house. ${ }^{12}$ As Helma states,

We were at war, and many farmers were soldiers and the whole responsibility lay with the wife. It was a very poor land, and most of us were a very good help in this situation. We had to mainly help the farmer from 8 or 9 in the morning till 4 o'clock, because all of the farmers were at war and the women had to do it. ${ }^{13}$

Though members of the foreign press saw such labour service as an opportunity to indoctrinate young minds, exploit women and recruit cheap labour, Helma reflects upon her experience differently; she divorces its meaning from ideology and indoctrination. ${ }^{14}$ She notes "by all means, we got a good portion of political instruction... [but] the goal was to get to know girls from other parts of Germany and their different lifestyles and learn to live together." German solidarity, which manifested itself in strong friendships. In addition, she recognized the utility of agricultural helpers, for indeed, she felt useful. Helma enjoyed her time at the camp much more than the two years she had spent in an office; it was a good personal experience, but also offered gainful employment, responsibility, and

\footnotetext{
${ }^{10}$ Frauenarbeit Winkler, 90, as cited in Frevert, p.229. Domestic service was another option for service. Domestic servants and agricultural labourers were in short supply; this is one reason why Nazi ideology promoted women's work of this sort. Jill Stephenson, Women in Nazi Society (London: Croom Helm, 1975), pp. 104, 191, asserts that although the party was motivated by a need for labour, in some respects, such work helped to mold the ideal Nazi woman: a peasant wife, devoted the land, and her family, physically active and healthy, and not concerned with looks.

1 Helma Kroll, memoir, March 8, 2001. Book 1 p.3.

${ }^{12}$ Helma Kroll, memoir, March 8, 2001. Book 1 p.3.

${ }^{13}$ Interview with Helma Kroll, June 8, 2005. p.1.

${ }^{14}$ Ramona Rose, Position and Treatment of Women in Nazi Germany: As Viewed from the Perspective of the English Language Press-1933-1945. (Vancouver: Tantalus Research Ltd, 1984.)

${ }^{15}$ Helma Kroll, memoir, March 8, 2001. Book 1 p.3
} 
leadership opportunities. ${ }^{16}$ After completing her requisite term, Helma chose to remain with the organization to receive administrative training. At twenty, she "had the responsibility for everything in the camp on the administrative part. This included not only all the garments for forty-eight maidens and about five staff persons, but the complete inventory and the food. Two years later, with some more courses and instructions, [she] was the leader of one of the camps until the end of the war." 17 This work provided Helma with "much pleasure and satisfaction." did not view herself as an exploited labourer; rather, she took advantage of the opportunities that the camp offered, ones which likely would have been unavailable elsewhere.

It is through this lens of personal betterment that Helma is at peace with her role during World War Two. It was a matter of personal resourcefulness and taking advantage of a good opportunity - not a connection to the war effort. Indeed, though Helma was in Czechoslovakia and it seems very apparent that she had no real affiliation with party policy or ideology, it is telling that she makes a conscious effort to detach herself from Germany and the war - until it was lost. Helma emphasizes that although she "saw some airplanes coming and going," she "never had a real connection with the war."19 Geographically, this would make sense; that being said, Helma's retrospective knowledge of what happened during the war - to loved ones and others - would also undoubtedly discourage her from speaking of any personal hardships, and encourage her to recall her

\footnotetext{
${ }^{16}$ Helma Kroll, memoir, March 8, 2001. Book 1 p.3; Frevert argues that opportunities like this were the regime's attempt to curb any real efforts at equality, by giving them positions in which they held little 'real' power. Frevert, p.241.

${ }^{17}$ Helma Kroll, memoir, March 8, 2001.Book 1 p.4.

${ }^{18}$ Helma Kroll, memoir in German, (undated, 1991) German Edition, Book 1,p.1 translated by Bob and Inge Harris.

${ }^{19}$ Interview with Helma Kroll, June 8, 2005, p.2.; Interview with Helma Kroll, June 8, 2005, p.1.
} 
own circumstances with gratitude. She asserts that at the camp, "we had good food in a time where there wasn't much food; we were lucky enough in that. ${ }^{, 20}$ She contrasts her war years with those of her mother, who (towards the end) "was still in Berlin and had poverty all the time," and lived under the constant threat of Allied bombing. ${ }^{21}$ Despite the fact that Helma must have been worried about her loved ones, no such mention is made, or seemingly, remembered. Though this could be conceived as further proof of Helma's ability to cope and remain positive, one must also acknowledge that this period is recalled in contrast to the difficult time she faced following the war-which likely would overshadow any previous difficulties.

1945 was a tumultuous year for Germans. It marked the end of the Second World War, a conflict from which the public had been repeatedly assured they would emerge victorious. In April 1945, Nazi propaganda proved fallacious when millions of Red army soldiers poured into Germany's Eastern region, unleashing a wave of havoc and devastation consistent with ultimate defeat. Up until the very end of the war, Helma did not comprehend Germany's true status: the war "was far away in our minds...it somehow didn't hit us in our corner; there were other corners from Germany who knew how terrible it was."22 Though she knew that the war was getting closer, and therefore sent the young women home from the camp at the beginning of April, Helma was denied a full understanding due to her isolated geographical position, and the lack of direct

\footnotetext{
${ }^{20}$ Interview with Helma Kroll, June 8, 2005, p.1.

${ }^{21}$ Interview with Helma Kroll, June 8, 2005, p.2. Kristina Minister asserts self-depreciation is common in women's oral testimonies. Minister, "A Feminist Frame for the Oral History Review," Women's Words: The Feminist Practice of Oral History. Sherna Berger Gluck and Daphne Patai, eds. (New York: Routledge, 1991),32.

${ }^{22}$ Interview with Helma Kroll, June 8, 2005, p.2.
} 
communication with the outside. ${ }^{23}$ It is instructive that in Helma's testimony she emphasizes her ignorance of the war and its reality. Though at no time does she refer to the Holocaust, it is likely that this denial of knowledge is implicitly related, particularly due to the ingrained connection which North Americans make between World War Two Germany and the Nazi death camps. For example, Helma recounts that towards the end of the war, in an effort to diminish any existing doubts she might have, she was reassured by a visiting leader that Germany was simply regrouping behind the lines and would emerge successful, for Germans "can make so many panzerfausts—-the Russian can never make so many tanks." ${ }^{24}$ Her self-portrayal, likely very accurate, is one of a naive young woman, who did and believed as she was told.

The course of Helma's future changed as the result of Germany's turning tide. German troops were coming through Czechoslovakia in their retreat from the Soviet Union, and Helma, who had remained with one co-worker as a camp "housekeeper," was present to meet several German units who stopped at the camp to use its facilities. In one of these companies was Helma's future husband, Reinhard Kroll. As Helma writes in retrospect,

It was April 11, 1945, a very dirty officer came and asked if he and his men could have a shower in our large bathroom. They could. -Afterwards a completely different looking man came in, good looking, to thank me. -'Peng!' this is what you call love on second sight. ${ }^{25}$

During the next four weeks, Helma and Reinhard "met as much as possible," making "some time for love and getting to know each other." ${ }^{96}$ Reinhard also made it

\footnotetext{
${ }^{23}$ This date is contested between Helma's autobiography and oral testimony (Interview with Helma Kroll, June 8,2005, p.2). In her oral testimony, she states that she thinks it was at the beginning of March. Because more time was put in the construction of the autobiography, and the other dates seem more consistent, I have chosen to use the information provided in the written form.

${ }^{24}$ Interview with Helma Kroll, June 8, 2005, p.2.

${ }^{25}$ Helma Kroll, memoir, March 8, 2001. Book 1 p.4
} 
very clear to her that the war was lost, forcing reality on her. He asked Helma to visit his parents, in order to tell them that he had been alive when she had last seen him. ${ }^{27}$ When the collapse came on May 5, Reinhard moved with his company westwards, in hopes of meeting American, and not Russian forces. ${ }^{28}$ Helma and her colleague left with the men, encased by a company of German soldiers who afforded them 'absolute protection' on their journey home. ${ }^{29}$ Though safe, they quickly lost Reinhard in the moving mass. The people shared their food and slept wherever they could; in "an 'end-of-the-world' atmosphere" there was a sense of a collective group. ${ }^{30}$ Helma and her friend stayed with the group until they parted for Dresden to seek her colleague's family. Following a brief stay there, Helma was on her own. She left to find her mother in Berlin, not knowing "if she was alive or not.",31

Here, Helma's life as a 'refugee' unofficially begins. She was a vulnerable and faceless figure in a mass of chaos, fear, and uncertainty. She recounts, "The whole atmosphere was so completely different on the way from Dresden to Berlin." "T2 "There were far more refugees, many women with children on the road, trying to go home, not knowing if there was still a home. Not knowing if the husbands or other family members were still alive." ${ }^{33}$ Like many, Helma faced the unknown with trepidation; though she traveled with others along the way, the group solidarity which had existed in her trek to

\footnotetext{
${ }^{26}$ Helma Kroll, memoir, March 8, 2001. Book 1 p.4.

${ }^{27}$ Interview with Helma Kroll, June 8, 2005, p.2.

${ }^{28}$ Here too, there is a discrepancy between the oral testimony and autobiography, although it is conceivable that the two might agree with each other. In her oral testimony, Helma states that Reinhard's company left because they wanted to go home together. (Interview with Helma Kroll, June 8, 2005, p.3.)

${ }^{29}$ Interview with Helma Kroll, June 8, 2005, p.3. It is interesting to note that although Helma and her friend were amongst the very few women in the mass of people (estimated by Helma to be 1500), they were not concerned about their safety with the German men. The danger came from outside-the passing Russian soldiers.

${ }^{30}$ Helma Kroll, memoir, March 8, 2001. Book 1p.4.

${ }^{31}$ Interview with Helma Kroll, June 8, 2005. p.3.

${ }^{32}$ Interview with Helma Kroll, June 8, 2005. p.3

${ }^{33}$ Helma Kroll, memoir, March 8, 2001. Book 1. pp.4-5.
} 
Dresden, was absent: "Everyone was only thinking of themselves and their family," which meant "people were reduced to survival of the fittest rather than sharing resources." 34

Food and shelter were in short supply. Those on the roads dug up potatoes in farmers' fields to stave off hunger. Helma recalls one particularly poignant incident which has haunted her throughout the years:

In my picture memory there is still an old woman, no, she was not old, she only looked it; she had two children, maybe four and six years old and also a baby in a pram. We talked and in the meantime the six-year-old snatched a piece of dry bread and ate it, and the woman cried that this was for the baby to suck on. She did not know where to go. She still follows me in my memory. ${ }^{35}$

Such brushes left a deep impression upon Helma, and would undoubtedly influence the memory of her own experiences - like a reference point — particularly as they related to food and family. Food shortages were rampant in postwar Germany, yet Helma makes little reference to them in her own life, likely because she saw so much worse and perceived any suffering she experienced as insignificant in comparison. That she remembered the woman, a single mother with young children, was most certainly related to her own sense of family values, ones which are woven in throughout her narrative.

Even before Germany's defeat was official, such tragic scenes of refugee mothers were not unusual, for hundreds of thousands of refugees had flooded into the gates of German territory. This westward movement, conceivably "the greatest population migration in central Europe for several centuries," was intensified due to the transfer of territory from Germany to Poland, east of the Odor-Neisse line. ${ }^{36}$ In addition, as German

\footnotetext{
${ }^{34}$ Helma Kroll, memoir, March 8, 2001 ..Book 1 p.5;Interview with Beate Myhill, June 8, 2005. p.4.

${ }^{35}$ Helma Kroll, memoir, March 8, 2001. Book 1 p.5.

${ }^{36}$ Mary Fulbrook, "Ossis and Wessis: the Creation of Two German Societies," German History since 1800. Mary Fulbrook, ed. John Breuilly assistant ed. (London: Arnold, 1997), p.411.
} 
armies retreated from the oncoming Red Army, expellees (the majority consisting of ethnic Germans, or Volksdeutche) joined them. From various corners of Eastern Europe, particularly Czechoslovakia, the USSR, and Poland (replete with new borders), these people fled due to fear and/or their physical removal by Soviet forces. Marlene Epp's examination of the Soviet rape of Mennonite women, illustrates the dangerous condition of Eastern Germany's postwar roads. Needless to say Soviet soldiers made the journey of female refugees particularly perilous; as Helma testifies, a curfew prevented civilians from being on the road between dusk and dawn. If no village or barn was found, Helma resorted to staying in the forest, which was far from safe. Though her later experience as a refugee would take a very different form than this one, this trek provides an interesting parallel: with few possessions, Helma was heading into the unknown,hoping for the best. Her refugee journey also sets the stage for the type of hardships with which Helma would have to contend, and her ability to persevere and make do.

Anton Ackermann, a Communist returning from exile at about the same time, describes the scene he found upon crossing the border into Germany from the East:

Hundreds and thousands were moving westwards: everywhere we came there were waves of refugees who had been launched westwards by the Wehrmacht and the SS so as to depopulate the East. Now they were being overtaken by the advancing Soviet troops. We ran into them at the edge of the road, deep in the woods, in village meadows and school yards, in the squares of the larger townshomeless, starving, ill, desperate, aimless and hopeless. Hundreds of thousands! ...We discovered a totally agonized people. That is the truth. They were incapacitated by the poison of despair, a mixture of shellshock from the nights of bombing and war, of deeply ingrained fear of Bolshevism and the gradual awareness of their own guilt at everything that had befallen Germany. ${ }^{37}$

\footnotetext{
${ }^{37}$ Fritz Selbmann, Die Erste Stunde, Verlag Neues Leben, Berlin, 1974, p. 9 quoting from 'Situationsbericht von Anton Ackermann' in Staat and Recht, (XIV, no.5, 1965); as cited by Jonathan Steele, Inside East Germany; the State that Came in from the Cold. (New York: Urizen Books, 1977), pp. 40-1.
} 
It was dangerous for Helma to have expectations about what awaited her in Berlin. The Allies had impelled Germany into an unconditional surrender, which was reinforced by the massive bombing of its major cities in the final year of the war. When Helma reached Dresden, she and her friend encountered the results of such action. Sixty-five percent of housing had been destroyed in Germany's large population centres, and nearly forty percent of the population had lost all of their material possessions. ${ }^{38}$ Basic necessities such as food, housing, and clothing were all desperately in short supply, particularly in the urban centres. Wolfgang Leonard, a Communist returning from exile, described his homecoming:

The scene was like a picture of hell-flaming ruins and starving people shambling about in tattered clothing. Dazed German soldiers who seemed to have lost all idea of what was going on, Red Army soldiers singing exultantly and often drunk; groups of women clearing the streets under the supervision of Red Army soldiers; long queues standing patiently waiting to get a bucketful of water from the pumps; and all of them terribly tired, hungry, tense and demoralized. ${ }^{39}$

Cold, hunger, want, and fear, characterized the immediate post-war period. Already dismal conditions (particularly in the cities) were exacerbated by the arrival of masses of dislocated people who had found themselves homeless at the end of the war. Helma's mother was in the American sector, which was much more favourable than being in the East. ${ }^{40}$ However, circumstances were anything but pleasant. When Helma reached Berlin she did not know if her mother's apartment would even be standing. She soon found that it was; however, her mother was no longer in it - the apartment had been occupied by

\footnotetext{
${ }^{38}$ Kirsten Poutros, "Von den Massenvergewaltigungen zum Mutterschutzgesetz. Abtreibungspolitik and Abtreibungspraxis in Ostdeutschland, 1945-1950," Bessel and Jessen, Die Grenzen, p.174; as cited by Bruce, Resistance with the People: Repression and Resistance in Eastern Germany, 1945-55. (New York: Rowman \& Littlefield Publishers, 2003), p. 46.

${ }^{39}$ William Leonhard. Child of the Revolution. (London: Collins, 1957), p. 298. As cited by Jonathan Steele, Inside East Germany; the State that Came in from the Cold. (New York: Urizen Books, 1977), p. 40.

${ }^{40}$ As a result of the Yalta Conference (January 1945) and the Potsdamn Conference (July-August 1945), Germany was a divided nation, split into four occupational zones: American, British, French and Soviet. Berlin was in the Eastern Region of Germany, but the city was split four ways.
} 
American soldiers. Instead, Helma found her mother living with friends in a stranger's apartment. ${ }^{41}$ Such was typical; housing was in tremendously short supply, thus several families cohabited apartments intended for one, sharing single rooms, kitchens, and very limited supplies. The make-shift 'war family' continued to exist as women anticipated their husbands' homecoming, or if word had already been received of their death, waited for the return of some kind of normalcy. ${ }^{42}$ Many Germans had to make room for refugees; Helma's mother was required to 'accommodate' (ie: vacate her apartment for) Allied troops. ${ }^{43}$ In essence, Helma and her mother were homeless, even though their home had not physically been destroyed. There was no authority that had the ability or responsibility to house them, and Helma felt like a burden on family friends. Had she remained, she "would have been one more problem to feed."44 The lack of housing, combined with a sheer lack of opportunity, fuelled Helma's resolve to leave Berlin. She did not know where her ultimate destination would be, but left with few alternatives, Helma decided to deliver the note to Reinhard's parents.

It is interesting that in relation to this decision, Helma does not emphasize her agency or bravery directly. Instead, she stresses her trepidation, as a "very well raised girl with a lot of principles." This statement tells her audience both that she was not 'loose' by the standards of the day, and indirectly informs them that this was a risky move for her,

\footnotetext{
${ }^{41}$ Helma Kroll, memoir, March 8, 2001. Book 1 p.5. Though Helma and her mother shared "a very happy reunion," they still did not know the whereabouts of Helma's grandmother, who had been evacuated from Berlin when the bombing started. Helma's grandmother was retumed to Berlin in September 1946; she had spent the end of the war in Silesia and then Poland.

${ }^{42}$ Anne Marie Tröger, "Between Rape and Prostitution: Survival Strategies and Chances of Emancipation for Berlin Women After World War II," translated by Joan Reutershan, Women in Culture and Politics: A Century for Change, ed. Judith Friedlander et al. (Bloomington: Indiana University Press, 1986), p.101. ${ }^{43}$ Maria Ritter offers an excellent account of being an unwanted refugee, and sharing others' homes and resources. Maria Ritter, Return to Dresden. (Jackson: University of Mississippi, 2004), pp. 89, 164-5, 1978; Military authorities got first priority, Displaced Persons second, and Germans last. They were often forced out of their homes. Milda Danys, DP Lithuanian Immigration to Canada After the Second World War. (Toronto: Multicultural History Society of Ontario, 1986), p.45.

${ }^{44}$ Helma Kroll, memoir, March 8, 2001. Book 1 p.5.
} 
which required both desperation (lack of other alternatives) and courage. Helma went to seek the family of a man whom she had known for only four short weeks. She "walked on with a much lighter knapsack in the direction toward Neu Glienicke," $250 \mathrm{~km}$ away, on a much emptier road than the one she had walked before. ${ }^{45}$ Though she was able to stay with friends along the way, the masses that had been on the road previously were absent. Again, the journey was dangerous for a young woman traveling in the Soviet zone. Whereas men had been the most directly afflicted during the war, the postwar experience left its greatest mark upon women, leaving them vulnerable and physically endangered; thus, on her travels, Helma left the road whenever Soviet troops were near. Nevertheless, despite her obvious fear of physical danger, one gets the impression that perhaps Helma's anxiety about her reception served as a potential distraction from the physical danger. Her last day of walking was the most difficult because she had to walk alone; yet, in one respect this was positive: it gave Helma time to practice "many, many approaches as to how [she] would introduce herself," to the perfect strangers who in one year's time would be her in-laws. ${ }^{46}$

The Krolls lived in a small village called Neu Glienicke, which consisted of five or six houses in the woods. Reinhard Kroll came from a family of foresters, who were steeped in tradition, pride, and a thorough education. Most forester families went back at least two or three generations, some as many as ten. ${ }^{47}$ The Krolls were no exception: Reinhard's two grandfathers had both been Forest Masters, as was his father; on his mother's side of the family, they were five generations. Though the forester's goal was

\footnotetext{
${ }^{45}$ Helma Kroll, memoir, March 8, 2001. Book 1 p.5.

${ }^{46}$ Helma Scholz (Kroll) to Eleonore Scholz. June 12, 1945. Book 1, Appendix p.2

${ }^{47}$ Michael Imort. "Forestopia: The use of the forest landscape in naturalizing National Socialist ideologies of Volk, race, and Lebensraum, 1918-1945." Dissertation. (Kingston: Queens University, 2000), p.137
} 
"preserving the forest and being a good game keeper," he was also a 'Respektsperson' or 'person in authority,' who socialized with important people in the community: other foresters, the doctor, teachers, lawyers, and pharmacists. ${ }^{48}$ He was an elite member of the civil service, and his family held a high social status. Helma later observed that foresters "very often married within their own circles" and that for them, "Nothing was more important than tradition. ${ }^{.49}$ Helma stresses this notion of exclusivity from the very beginning of her narrative, particularly her memoir. Perhaps this status contributed to the subsequent pull that Reinhard's parents had on the couple in later years. Undoubtedly, the more immediate arrangement that Helma reached with them would also colour their relationship.

The Krolls' home was the largest in the village. Though Helma recognized it from Reinhard's description, she approached it with trepidation. No one initially answered the front door, and as she pushed it open, 'through a still intact glass door [she] saw into a big room, with broken and upset chairs, pulled out drawers, part of a dining table, broken dishes: it was a frightening picture." ${ }^{50}$ Nonetheless, she soon met Reinhard's parents, and his aunt and uncle who were staying there. They were delighted to hear her message because it gave them hope; they had lost two sons in the war, and waited word of the remaining two. ${ }^{51}$ When Helma told them that she had no further plans, she was invited to stay as the "Girl Friday for Everything, with Family Ties." 52 The Krolls no longer had

\footnotetext{
${ }^{48}$ Helma Kroll, memoir, March 8, 2001.Book 1 p.1; Imort, p. 275.

${ }^{49}$ Helma Kroll, memoir, March 8, 2001, p.1 This element of tradition and class is an interesting one to bear in mind. Withholding circumstances from the war, Helma likely would not have been the Krolls' ideal daughter in law based on her background, as she did not come from a similar tradition or 'upper-class' background.

${ }^{50}$ Helma Scholz (Kroll) to Eleonore Scholz. June 12, 1945. Book 1, Appendix p.2.

${ }^{51}$ Helma Kroll, memoir, March 8, 2001.Book 1 p.5. Likely, the senior Krolls' need for contact with Reinhard in later years was fuelled by the loss of two other sons during the war.

${ }^{52}$ Helma Kroll, memoir, March 8, 2001.Book 1 p.6.
} 
any hired help and thus within half an hour, Helma was dressed for work and sweeping the barnyard. ${ }^{53}$

The Krolls were not unanimous in the decision to invite Helma to stay. In retrospect, Helma recognizes that her presence posed "difficulties for the whole family." 54 She states:

Mutti Kroll did not let me leave again even with all the rightful opposition from Vati Kroll and Aunt Gertrud, who thought that the Russian soldiers might have 'interest' in me. But I also was in denial and refused to believe in this danger. ${ }^{55}$

The Soviet Military Administration in Germany (SVAG) was formally established in the Eastern zone on 6 June 1945. From the onset it was disorganized and uncoordinated. ${ }^{56}$ While Stalin was evidently concerned with keeping a tight command over the Eastern zone, his primary concerns towards the region between 1945 and 1947 can be characterized as denazification, punishment, and reunification. ${ }^{57}$ Though a contentious issue amongst historians, Soviet actions taken during this period support the notion that little thought was given to constructing a viable long-term East German state; thus, the well-being of both the Eastern Zone's economy, and the living conditions endured by her citizenship, were of little importance to Soviet officials. ${ }^{58}$ This is apparent in the experience of ordinary Germans, whose trials under the Soviet occupation included rape, looting (both on a personal level and soon on a national, economic one), 'police' action, or simply hunger, as a result of their victors' occupation.

\footnotetext{
${ }^{53}$ Helma Kroll, memoir, March 8, 2001.Book 1 p.6.

${ }^{54}$ Helma Kroll, memoir, March 8, 2001.Book 1 p.6.

${ }^{55}$ Helma Scholz (Kroll) to Eleonore Scholz. June 12, 1945. Book 1, Appendix p.3.

${ }^{56}$ Norman N. Naimark, The Russians in Germany: A History of the Soviet Zone of Occupation, 1945-9. (Cambridge: The Belknap Press of Harvard University Press, 1995), p.12.

${ }^{57}$ Jonathan Steele, Inside East Germany; the State that Came in from the Cold. (New York: Urizen Books, 1977), p.36; Katherine Pence, "The Myth of a Suspended Present: Prosperity's Painful Shadow in 1950s East Germany." Pain and Prosperity: Reconsidering Twentieth Century German History. Paul Betts and Greg Eghigian, eds. (Stanford: Stanford University Press, 2003), p.140.

${ }^{58}$ Steele, p.36.
} 
The last Soviet offensive, launched from the East 16 April 1945, was comprised of 2.5 million Red Army soldiers under Marshall Zhukov. By 1 May, Soviet troops had emerged victorious from the battle for Berlin; their behaviour towards German civilians made the defeat of Germany apparent, and would harvest nation-wide feelings of resentment and victimization amongst the population. ${ }^{59}$ The state of the house which Helma first encountered was the bi-product of the Soviet victory. In the last days of the war, the Krolls had left their home, hoping to find protection in the nearest city. At this point, the house was looted by Polish, German and Russian soldiers; however, it was only the Russian soldiers who repeatedly returned to pillage. "The Krolls tried to get back some order" after the first invasion,

with the result that they gave the Russians, who invaded at any hour day or night, better oversight as to what to take. Nearly every day, two or three trucks stopped, found things they wanted, or just broke them. Many items were found later on, broken in the woods. ${ }^{60}$

The Krolls were left with nearly nothing: in a letter to her mother, Helma notes that "Mutti Kroll has only the underwear which she was wearing" during the raids. ${ }^{61}$ Helma explains

The Russians still had their men just getting loose. I believe that they never had so much before. They just took their little jeep or whatever they had, and stopped at a nice looking house... They took everything...just to disturb...just for the sake of damaging... In the woods, there were so many chairs. They took them out of the house, put them in the truck, and threw them away. They didn't need them. ${ }^{62}$

Despite the Krolls' victimization by looters, Helma manages to find light in such experiences. She recalls a humorous incident, in which the family was tricked:

\footnotetext{
${ }^{59}$ Atina Grossman, "A Question of Silence: The Rape of German Women by Occupation Soldiers." October, "Liberators Take Liberties" 72 (Spring, 1995): 62.

${ }^{60}$ Helma Scholz (Kroll) to Eleonore Scholz. June 12, 1945. Book 1, Appendix p.3.

${ }^{61}$ Helma Scholz (Kroll) to Eleonore Scholz. June 12, 1945. Book 1, Appendix p.3.

${ }^{62}$ Interview with Helma Kroll, June 20, 2005. pp.1-2.
} 
A sergeant came up for a coffee visit, how this happened I don't know anymore. Well Mikael (I even still remember his name) was sitting with us, had his coffee and tried to make a conversation in German. Later, after he left, we commented that he was really a nice guy. But then we got down into the kitchen: Surprise! His companions had cleaned out the kitchen and Mikael was only with us so that we would not disturb his friends... ${ }^{63}$ [Mikael] was diverting, but this was at least not dangerous. [But] we were so pleased with [Mikael], how nice he was. [laughs] Never will forget this! ${ }^{64}$

In contrast to this incident, Helma has much more difficulty discussing a more personal form of assault. Though the plundering was widespread, the most insidious crime which the Soviet troops imposed upon the German citizens was gendered. When Reinhard's aunt and uncle had opposed Helma's lodging, they stated it was "not safe for a young woman, or for them." ${ }^{65}$ Unfortunately for Helma and the Krolls, these fears were to be realized.

The Red Army's systematic rape of German women, from pre-pubescent girls to women in their eighties, is well-documented. ${ }^{66}$ The estimates of German women raped during the Soviet occupation vary widely: from 20,000 to 500,000 , to $2,000,000{ }^{67}$ Soviet propaganda had worked effectively in its efforts to create hostility towards the German people; on the eve of the last great offensives, they sent out a directive stating:

...on German soil there is only one master - the Soviet soldier, that he is both the judge and the punisher for the torments of his fathers and mothers, for the destroyed cities and villages... Remember your friends are not there, there is the next of kin of the killers and oppressors. ${ }^{68}$

\footnotetext{
${ }^{63}$ Helma Kroll, memoir, Book 1 p. 9.

${ }^{64}$ Interview with Helma Kroll, June 20, 2005. p.4. Note there was some confusion regarding his name, in her oral testimony, Helma referred to the name as Ivan, in her memoir, Mikhael.

${ }^{65}$ Interview with Helma Kroll, June 8, 2005, p. 5.

${ }^{66}$ Naimark, p.80.

${ }^{67}$ Marlene Epp citing Annemarie Tröeger and Barbara Johr in "The Memory of Violence: Soviet and East European Menonite Refugees and Rape in the Second World War," Journal of Women's History 9, no.1 (1997): 60.

${ }^{68}$ P.A. Pirogov, "Vospominanii o sluzhbe v armii I o begsve..."manuscript, p.9 HIA, Nicolaevsky, box 249-9, Series 193 cited by Naimark, p. 72.
} 
Such messages were typical of those given to Soviet soldiers throughout the war, and were devastatingly successful in their efforts. ${ }^{69}$ Wartime propaganda had held that German women were as responsible as German men for wartime atrocities, and cited them as fat bourgeoisie, greedy and spoiled. ${ }^{70}$ The use of war time propaganda combined with a high degree of alcohol consumption, the shock of German wealth, the violent atmosphere of the Red Army itself, and the Soviet soldier's own personal experience (for example, the knowledge of atrocities committed against one's own family by German troops), created the conditions under which rape became a justified act of gendered war time violence. ${ }^{71}$ The 'taking' of women was the appropriation of another man's property and it symbolized a way of dishonoring the enemy; in this respect, the 'defeat' of women substituted for the defeat of men. ${ }^{72}$

Like many women, Helma is reluctant to discuss her rape, obviously a traumatic and emotional experience. She states only in a hasty manner that "my mother in law and I had the experience of quite a lot of...Russian soldiers..."73 Within the letter collection, Helma included a modest selection of letters which refer to the rape and its aftermath. In her commentary, she refers to the box containing these powerful letters as the "Pandora Box," for "reading [them] brought back many memories."74 Marlene Epp, in her study of

\footnotetext{
${ }^{69}$ It should be noted that the attitude of the Soviet officials changed re: rape of civilians. While initially Red Army officials practically endorsed the rape of defeated civilians. Stalin could "...understand it if a soldier who had crossed thousands of kilometers through blood and fire and death ha[d] fun with a woman or $\mathrm{t}$ [ook] some trifle" Naimark, p. 71. However, by the time Soviet troops actually reached Germany's borders, Stalin, Zhukhov, and Aleksandrov had all issued directives to not seek revenge, in the interest of forging positive relationships with Germans, particularly those of the proletariat. Unfortunately, these directives were not heeded, as there was not enough time to undo the years of anti-German education. Naimark, p.77.

${ }^{70}$ Naimark, p.108.

${ }^{71}$ Naimark, pp.108-115; Epp, Journal of Women's History, 9, no.1 (1997): p.61.

72 J. Glenn Gray., The Warriors: Reflections on Men in Battle. (New York: Harper, 1959), pp.66-7, as cited by Naimark, p.70.

${ }^{73}$ Interview with Helma Kroll, June 8, 2005, p. 6

${ }^{74}$ Memoir, January 1996. Book 1 Appendix p.1.
} 
Mennonite rape victims, observed that for many, rape is a subject 'too painful' to delve into; consequently, because of its sensitive and painful nature, the tendency of many who record or write life histories (both interviewer and interviewee) is to create a 'clean' narrative. ${ }^{75}$ Helma's inclusion of such an event in the collection must have required a great deal of courage, and indeed, in her oral testimony she has difficulty speaking of it; instead, she lets the letters speak for her. Beate remarks that initially, Helma was not even "going to include the stuff about what happened at the end of the war ... [it] was going to be just for [her] and [her younger sister.]"76 However, though Helma is understandably still scarred by the assault and wishes to avoid it as the topic of conversation, as time passed, she chose to include references to the incident, and thus demonstrated her willingness to recognize and share it. In her commentary she attempts to explain her decision to at least include her letters as follows: "In a way I doubt that you will understand our situation at all, but I feel, you should be given the chance." ${ }^{77}$ In all likelihood, she is referring to the feeling of betrayal and defeat which swept through the German population, symbolized by the violent pillaging of both material and women.

Our window into Helma's rape is provided by a series of letters which Helma wrote while in hiding (away from the Krolls in order to be sheltered from further assaults). These letters are some of the little surviving correspondence written shortly after the war, and are primarily written between Helma and her mother, although there is also correspondence to her grandmother and Reinhard's mother. This short series reaffirms Margaret Conrad's observation that letter writing was an important method with which women communicated and built upon existing support networks, whether the

\footnotetext{
${ }^{75}$ Epp, Journal of Women's History, 9, no.1(1997):.60-61.

${ }^{76}$ Interview with Beate Kroll, Aug 20, 2006, p.14.

${ }^{77}$ Memoir, January 1996. Book 1 Appendix p.1.
} 
distance be transatlantic or interregional. ${ }^{78}$ Letters provided a source of comfort and support, which Conrad points out was particularly significant to sisters; Helma did not have any siblings and lacked close friends from her childhood in Berlin; it is within such a context that we place the relationship between her and her mother. ${ }^{79}$ In the sequence of letters written during this period one senses that Helma is coming to terms with the trauma she experienced. She needs the comfort of (absent) female loved ones, even if 'only' through correspondence.

To her mother, Helma describes the rape which occurred within the week of her arrival, at the beginning of June 1945. The entire household, including Helma, was aware of the dangers which Helma's presence posed, so they took precautions and hid Helma every time Russian soldiers were nearby. However, one evening, Russian soldiers entered the home without warning; she did not get into her 'usual hiding place' on time and was noticed. Though "[the soldiers] did not take much at that time," they were to return.

Helma tells her mother of the violence with which she was attacked.

It was terrible to be under the mercy of those animals. Mutti Kroll, who tried to get some help, was caught and one of those beasts raped her too. They had blocked off Mr. Kroll, and Kuno and Gerturd could not have done anything. Five men raped me, one after the other. ${ }^{80}$

Like many German women, Helma portrays her attackers as 'beasts,' 'animals,' and 'monsters'; they are estranged from any 'human' descriptors, which is understandable

\footnotetext{
${ }^{78}$ Margaret Conrad. "Recording Angels: The Private Chronicles of Women From the Maritime Provinces of Canada, 1750-1950.” (Ottawa: CRIAW/ICRAF, 1982), p.14.

${ }^{79}$ Margaret Conrad, “'Sundays Always Make Me Think of Home': Time and Place in Canadian Women's History," Not Just Pin Money: Selected Essays On The History Of Women's Work in British Columbia. Barbara K. Latham and Robert J. Pazdro, eds. (Victoria: Camosun College, 1984), 13.

${ }^{80}$ Helma Kroll to Eleonore Scholz. June 12, 1945. Appendix p.4. Kuno and Gertrud were Reinhard's uncle and aunt.
} 
given the brutal violence with which many of the assaults were committed. ${ }^{81}$ The prolonged threat of rape contributed to an environment of fear amongst female German civilians in the East. ${ }^{82}$ Germans had feared the arrival of the Soviets due to effective Nazi propaganda; ${ }^{83}$ however, even they were taken aback by the extended period of disorganization and plunder that accompanied war and defeat: it seemed illogical. ${ }^{84}$ In addition to the rampant looting and pillaging of German civilian homes, it created a very uneasy relationship between Eastern Germans and their Soviet 'liberators. ${ }^{85}$ The mass rapes, the horror stories of returning POWs, Russian plunder, and food shortages created a memory of common victimization: a 'new national community of suffering' amongst East Germans, one which did not inspire confidence in the new regime. ${ }^{86}$ Even in cases when suffering was not acute or so apparent, this underlying current often surfaced. Victimization by Russians was compounded by the emotional devastation of many citizens, who had been tied to Hitler's Reich. They were at a loss due to the abandonment by their Fuhrer, but moreover, by the crimes he had committed, in which they as citizens were now implicated. Hence, a sort of self-pity combined with widespread disillusionment appeared. In retrospect, Helma writes of her grandmother "that she, as so many of us, was convinced of the correctness and honesty of the Hitler regime, and didn't

\footnotetext{
${ }^{81}$ Grossman, "Liberators Take Liberties" October 72(Spring 1995): 42-63, 59-60. Also see Epp, Journal of Women's History,9, no.1 (1997):,66. Grossman testifies there was a sort of split perception: the animalistic Russian vs. the civilized one. The 'savage' portrayal was in part exacerbated by the Asiatic appearance of some Soviet soldiers, who were of Mongolian descent.

82 Naimark, p.112.

${ }^{83}$ German propaganda stressed the dangerous and violence nature of Soviet troops. Grossman,,.p. 49.

${ }^{84}$ Rape was a regular act committed against East German women by Soviet soldiers through until at least 1947. Naimark, pp.86-8.

${ }^{85} \mathrm{Or}$, as Susan Brownmiller contests, many German citizens came to see the Soviets as conquerors. Brownmiller,_Against Our Will, (New York: Simon and Schuster, 1975), p.64 as cited by Naimark, p. 107.

${ }^{86}$ Though women talked openly about the rapes during the initial stages of occupation, by 1946, with the incoming elections, the Soviet Military Administration blocked German Communists (the KPD) from discussing them. Women were therefore barred the right to really seek justice for their victimization. Grossman, October 72 (Spring 1995): 49-50, 61-2.
} 
know anything of the atrocities, which we were all blamed for after the war." ${ }^{97}$ In reference to a friend, Helma writes to her mother that

She was very kind but very upset, and was crying a lot. I can't understand it, she has her husband and a very nice boy at home, which did not get damaged during the war. But I think right now everybody feels more or less sorry for themselves. ${ }^{88}$

German soldiers were also very aware of the revenge which awaited them. Reinhard eventually chose where to be discharged based upon his knowledge that some Russian camps "were really horrible, some of them were absolute, where thousands and thousands of German soldiers died. It was revenge. ${ }^{, 89}$ Ordinary civilians, such as Mr. Kroll, had been the victim of interrogations. When Helma first arrived at the Krolls, she comments that Herr Kroll was "trying to grow a beard to look older than his 62 years. The Russians had interrogated him for eight days, and he has not yet recuperated from this ordeal. $" 90$ Not everyone was so lucky; his brother was also arrested, but would die in a concentration camp that summer. Even though Herr Kroll (and presumably his brother, who came from the same educated and socially elite background) was a prime target as a 'wealthy' man, his suffering was shared by many of his fellow citizens, elite or not.

Considering her personal trials, it is understandable that Helma frames this period as one of victimization. During the war Helma had little contact with the fighting: her 'war years' truly started when the fighting had ceased. Following her rape, she wrote, "I start to question God and all the fairness and mainly the right of freedom, how helpless we are." 91 The morning following the assault, Mr. Kroll took Helma to Rheinsberg and lodged her with a former colleague in an old castle, where she would be safe (and thus so

\footnotetext{
${ }^{87}$ Helma Kroll memoir, January 1996. Book 1, Appendix p.9

${ }^{88}$ Helma Scholz (Kroll) to Eleonore Scholz. June 12, 1945. Book1, Appendix p.2.

${ }^{89}$ Interview with Helma Kroll, June 8, 2005, p. 6.

${ }^{90}$ Helma Scholz (Kroll) to Eleonore Scholz. June 12, 1945. Book 1, Appendix p.3.

${ }^{91}$ Helma Scholz (Kroll) to Eleonore Scholz. June 16, 1945. Book 1, Appendix pp.5-6.
} 
would the rest of the family). ${ }^{92}$ It was a wise idea, for the day after her rape, the Russian soldiers returned, looking for her. Here, in writings to her mother, we see the bonds of female solidarity, which occurred between daughter and mother, sisters, friends, and neighbours. This system of comfort was used by many German women to recover from their ordeal. ${ }^{93}$

Women separated their bodies from themselves, and emphasized that although perhaps physically 'defiled' or sullied, their spirits remained intact. ${ }^{94}$ Helma was grateful that her body seemed to have suffered no lasting aftereffects; still, she places emphasize on her sexual mores. To her mother, she wrote "Mentally, it was terrible, but as a healthy person I can't carry this ballast with me. Until now I have lived a clean life and I promise you, I will do so again."95 Mrs. Kroll uses similar language, and writes to Helma, "Dearest, you will get over it. You are such a clear, clean and brave woman." 96 Here one notes the emphasis on cleanliness; such sexual activity not only put women at risk for STD's and pregnancy, ${ }^{97}$ but it also challenged the position of a 'good,' wholesome

\footnotetext{
${ }^{92}$ Helma Kroll, memoir, March 8, 2001, Book 1, p.6.

${ }^{93}$ Grossman, "Liberators Take Liberties," October 72 (Spring 1995):50; Tröger, Women in Culture and Politics: A Century for Change, p.103. As Tröger asserts however, many German women chose to kill themselves over such a loss. Nevertheless, for the most part, German women did not feel the sense of shame which would have occurred in other less extraordinary times. This created gender relation problems with German men, who were perceived as doing nothing to protect their women, and thus often felt emasculated. (Grossman, October, p.62, Tröger, Women in Culture and Politics: A Century for Change, p. 105)

${ }_{94}$ Tröger, Women in Culture and Politics: A Century for Change, p.111 states that this form of female agency allowed for a continuation of a positive self-identity and thus survival.

${ }^{95}$ Helma Scholz (Kroll)to Eleonore Scholz. June 12, 1945. Book 1, Appendix p.4.

${ }^{96}$ Elfriede Kroll to Helma Scholz (Kroll). June 7, 1945. Book 1, Appendix p.5.

${ }^{97}$ During the postwar period, there were 20 million women of childbearing age, and 2 million abortions performed, most dangerous and illegal. Diewelt, Aug 171948 in SAPMO-BA, ZPA, IV, 2/17/29 6.112 as cited by Naimark, p.123. One nurse described the postwar situation at an East German hospital: "After a while, [for] the expectant mothers who were raped, pregnant women and girls, there were no more normal births anymore. Only abortions, abortions, abortions. From morning till late." Interview 2, Epp Journal of Women's History, 9, no.1 (1997):74.
} 
woman. ${ }^{98}$ Again, the solace provided from other women was invaluable in this respect; between Mrs. Kroll and Helma, it came from shared experience.

Despite the danger on the outside, Helma soon grew frustrated with her isolation at the castle. She wrote to her mother:

I can't go out, must not go near a window, (to give the Russian soldiers no idea that I am in the house) and am protected like a raw egg. It is very kind, but I have enough of it and would like to escape. ${ }^{99}$

After five weeks, Helma was tired of her confinement and walked back to Berlin, where her mother had regained her apartment - though only for a short period. ${ }^{100}$ However, once in Berlin Helma realized that the situation had not ameliorated substantially: she still had "no future there." ${ }^{101}$ Mrs. Kroll subsequently wrote to Helma telling her that order had been somewhat restored; Helma found this to be true, and returned to Neu Glienicke where "the situation had improved, with fewer Russians around and a stricter command." 102

When Helma returned in August, she found the household had received other help. She wrote to her mother that although she would have liked to continue working alone, “friendly" neighbours did not like this new arrangement" and shortly thereafter, she was drafted for work at a sawmill. ${ }^{103}$ Here, one can read between the lines, and perhaps see aspects of a class-based, Soviet-styled, socialist ideology encroach upon the

\footnotetext{
${ }^{98}$ Some German men, upon returning to Germany abused the experience of rape and took advantage of "loose' women. "May I offer you a little abuse?" was a sort of acceptable pick-up line for German men to use. Tröger p.112 Epp comments that some German women committed suicide rather than face rejection by their own men. Epp, Journal of Women's History, 9, no.1 (1997):.73.

${ }_{99}$ Helma Scholz (Kroll) to Eleonore Scholz. June 12, 1945. Book 1,Appendix p.4

${ }^{100}$ Interview with Helma Kroll, June 8, 2005, p. 6.

${ }^{101}$ Interview with Helma Kroll, June 8, 2005, p. 6.

${ }^{102}$ Helma Kroll, memoir, March 8, 2001, p.6 Again, a discrepancy exists b/w oral testimony the autobiography. In the autobiography, Helma suggests she returned to pick up her things, and ended up staying. In her oral testimony, Helma suggests that when she left Berlin, she left to return to the Krolls for a more definite period. (Helma Kroll, memoir, March 8, 2001, Book 1, p.6; Interview with Helma Kroll, June 8,2005 , p. 6.)

${ }^{103}$ Helma Scholz (Kroll) to Eleonore Scholz. September 1, 1945. Book 1, Appendix p.8.
} 
Soviet Zone in Eastern Germany. Helma was soon relieved of her duties by a Soviet commander because of the 'temptation' she posed to Russian soldiers who dropped off and picked up lumber. ${ }^{104}$ Though order had been partially restored, it was not yet fully realized. Nevertheless, this turn of events seems to foreshadow the 'informing' on friends and neighbours that became a crucial part of Volkspolizei (later known as the Stasi) intelligence; this in turn would be a key to German communist control, and furthermore, a motivating factor of the Krolls' flight. ${ }^{105}$

In November 1945, Helma received "a wonderful surprise" when Reinhard returned to his parents' home. He had made the dangerous journey back through the woods, for as a German officer, he would have faced arrest by the Russians. He stayed for only a brief period, but when he left, Helma was engaged. They traveled to Berlin to meet her mother, before he continued his 'work' which took him into the American zone.

As will be further discussed, much of Reinhard's work was on the black market, and involved trade in food. Particularly during the initial postwar period, food was a crucial concern to German citizens, and the ability to obtain it, especially in urban areas, was strongly dependent upon the black market economy. In the countryside, farmers grew their food. Throughout Germany, money was of little value, but for farmers, food was

\footnotetext{
${ }^{104}$ Interview with Helma Kroll, June 20, 2005. p.2.

105 Mary Fulbrook, The Two Germanys, 1945-1990 Problems of Interpretation. (London, MacMillan, 1992), p.38. In addition, one might also read this as indicative of socialist notions towards women and work. However, I find this interpretation problematic; it was German neighbours who were 'troubled' by Helma's lack of work; I see this as pointing more to issues of class and jealousy, conflict which the Soviet leaders would have been happy to accommodate; Thomas Lindenberger, p.126. Bruce, p.69 comments how the SED made use to rid the Soviet Zone of its political opposition.
} 
available and could be used to trade for other goods. ${ }^{106}$ For example, Mrs. Kroll would pick wild blueberries and trade them for whatever was needed. As Helma states:

This was the way I got a very nice skirt made from good blue military material. Later I needed a winter coat, which was made from an old coach coat, but the dressmaker's work was paid with some things we had, eggs or butter. At this time you only could get anything in a trade. ${ }^{107}$

Though food was rationed and the surplus was often requisitioned by Soviet forces, farmers, such as the Krolls, generally "had enough." 108 Helma makes a conscious effort in her testimony to convey her material subsistence during the post war years as entirely adequate. Unfortunately, her letters during this period are unavailable; however, how she now remembers this time is equally important. Helma continues to minimize her suffering, likely due to her knowledge of what others experienced: hardship was relative.

The reality for those in the city was very different from that of rural residents, especially (but not exclusively) in the Eastern Zone. For example, in overcrowded cities such as Berlin, some Germans received only 800 calories per day between 1945 and 1948; many (and quite likely most) consumed drastically less than the League of Nations' 1936 daily caloric minimum of 1,800 (for those not working). ${ }^{109}$ Materially, the Soviet Occupation further devastated a bleak economy. "I can't afford to work -I have to feed my family," was a joke that hit home for many East German urban residents during the

\footnotetext{
${ }^{106}$ Mary Fulbrook, The Divided Nation: A History Of Germany 1918-1990. (New York: Oxford University Press, 1992 ), p.152; Danys states that in the West, the blackmarket was run between American GI's and farmers. Danys, p.48.

${ }^{107}$ Helma Kroll, memoir, March 8, 2001. Book 1, p.7.

${ }^{108}$ Interview with Helma Kroll, June 20, 2005. p. 2. However, enforced collectivization would change this circumstance.

${ }^{109}$ Danys, p.44. Displaced Persons received priority for food because they had often been forced labourers, and thus the Allied Occupation considered the German population responsible for their welfare. Mark Wyman. DP Europe's Displaced Persons, 1945-51. (Toronto: Associated University Press, 1989), p.52.
} 
initial years of Soviet Occupation. ${ }^{110}$ Russian-imposed reparation payments crippled the economy and resulted in paid wages which held little real value, leaving workers on the brink of starvation if they depended upon their wages alone during the first year following the war. ${ }^{111}$ In order to survive, large numbers of the population actively participated in a thriving black market economy. ${ }^{112}$ Workers had greater incentive to participate in the potentially-lucrative black market than attend to their factory work. This led to a high rate of worker absenteeism, creating a direct cause and effect relationship between black market participation and the futile effort of rebuilding the economy. ${ }^{113}$ Foodstuffs produced by farmers (meat, vegetables, butter, etc), industrially produced foods and semiluxury items (alcohol, cigarettes, sugar, etc), manufactured items (medicine, women's stockings, etc), and human services (such as prostitution) were amongst those commodities in high demand. ${ }^{114}$ Reinhard had had "tremendous luck" following the war,

\footnotetext{
${ }^{110}$ Thurnwald, Gegenwartsproblem, 18, "Stenographische Niederschrift über die Frauenkonferenz am4. November 1946,"IV 2/1.01/22 folio 32, SAPM-DDR-BA; as cited by Elizabeth D. Heineman, What Difference does a Husband Make? Women and Marital Status in Nazi and Postwar Germany. (Berkeley: University of California Press, 1999), p.86.

11 Arvid Robert Nelson, "Acid rain and romanticism: East German forestry, 1945-89" PhD thesis, (Yale University, 1998), pp.17, 39; Jeffrey Kopstein, The Politics of Economic Decline in East Germany, 19451989 (Chapel Hill: University of North Carolina Press, 1997), p.21.

${ }^{112}$ In Berlin alone, an estimated $85 \%$ of the population participated in the black market in 1947. Heineman, p. 84. Roesler states that almost the entire population participated in the black market. Despite SED campaigns to halt it, by the end of 1947 most families openly engaged in illicit practice, as it had become a necessity to acquiring basic goods, particularly in cities. Jörg Roesler, "The Black Market in Post-war Berlin and the Methods Used to Counteract it," German History, (7(1) 1989), 92-107.

${ }^{113}$ Roesler, German History, (7(1) 1989), .94. The 'black market problem' was not adequately resolved until workers had some degree of purchasing powers. In the late 1940 s, low wages were compounded by an egalitarian type of sentiment which permeated factory life and prevented any sort of motivation to increase individual productivity. Police raids, the opening of 'free markets' and the addition of one or two warm meals to workers were ineffective against the problem of illicit trading, it was not until the Trade Organization (HO) under the SED were set up in Fall 1948, and began to drop their prices in 1949 that the steam was taken out of the back market as a "social phenomenon of politico-economic importance." Roseler, German History 7, no.1 (1989):107.

${ }^{114}$ Roesler, German History 7, no.(1 (1989): 92; Tröger in particular has written a great deal about the fine line between rape and prostitution during the initial period of Soviet Occupation. In recent discussions, prostitution has been viewed as an act of agency in an otherwise victimized role. Women could 'choose' to become attached to "one wolf' (or Soviet Officer) in order to both protect themselves from rapes by other Red Army members, and provide themselves and their families with adequate provisions in a time of deprivation. A more traditional form of prostitution was also an act of agency, a survival strategy in a time
} 
and made his way to West Germany. There he immediately became 'employed' in the black market system "dealing cigarette paper for sugar, flints for cigarette papers, and so on..." ${ }^{115}$ He was quite successful. Helma recounts the meeting between Reinhard and her mother: "he did not ask in carefully chosen words for my hand: He said 'Mrs. Scholz can I get your daughter for two packs of tobacco?"" She further exclaims, "There you see how much tobacco was worth!!" ${ }^{116}$ Clearly, material goods were on the mind of everyone, and held great value--explaining why this preoccupation would continue for some years to come. Even after Reinhard resumed work as a forester at the beginning of 1946, he continued to smuggle goods across the border. ${ }^{117}$ As Helma puts it:

It was a mercenary life and many people, including [Reinhard] had a hard time to adjust to a normal life again. [But] a shock therapy helped... he had just gotten employment in the Forestry. In the second week, for one reason or another, he had to go on a short business trip. We expected him back two days later; instead his boss got a phone call from the police in Potsdam that he had been caught trading flints for something. That was the last of it. ${ }^{118}$

Although Helma refers to this as the last venture, further in the same memoir passage, she refers to a last minute 'business trip' for more flints several months later. Perhaps this trip was an anomaly; nevertheless, she states that she "understood and could not have changed much anyways." 119 Where poverty was widespread and real wages scarce, the black market was an essential source of income to many citizens, including Reinhard.

\footnotetext{
where options were limited, and "...the boundaries between legal and illegal activity were so fleeting." Heineman, p.85.

${ }^{115}$ Helma Kroll, memoir, March 8, 2001. Book 1 p.8.

${ }^{116}$ Helma Kroll, memoir, March 8, 2001. Book 1 p.8.

${ }^{117}$ Helma explains to her modern audience: "You don't know this expression, but at this time we called, what later on was the 'Zonen Grenze' the green border. Nobody was allowed to cross it without a 'pass document', which was very difficult to get. So we went 'black' over the 'green' border. Helma Kroll, memoir, March 8, 2001. Book 1 p.8.

${ }_{118}$ Helma Kroll, memoir, March 8, 2001. Book 1 p.8.

${ }^{119}$ Helma Kroll, memoir, March 8, 2001. Book 1 p.9.
} 
Helma and Reinhard were married 1 March 1946, with a ceremony and celebration which reflected the times. Helma's outfit was makeshift: borrowed, left-over, found, and stolen. Yet, despite its humble nature, when recalling the event Helma's face physically lights up and her voice becomes animated as she recounts her special day. The tropes with which she frames her wedding are revealing, and revolve around loved ones, happy coincidences, and most of all, making do with little by way of material things. The latter is illustrated by the detail with which Helma remembers the clothing and food present during her wedding ceremony and festivities. She states "... all together, while I may not have looked like a stunning bride, I was a very happy one." Her day was the product of a cooperative effort. Because Helma had spent the war at the Arbeitsdienst, she had only her standard uniform dress and shoes, and no civilian clothing. The parents of a friend loaned her a blue dress and coat, which she wore with her everyday-shoes. Her head was adorned with a hat which Reinhard had found on his travels at a train station, but which her mother and friend later 'rejuvenated. ${ }^{120}$ For flowers, two of Helma's friends 'organized'-ie: stole — two bouquets. ${ }^{121}$ The wedding thus was pieced together with the help of loved ones. The ceremony was small, with only five people present. However, in a strange twist of fate, for the civil ceremony, the justice of the peace had decorated his office with two boughs. ${ }^{122}$ Afterwards, the man asked Reinhard "You are wondering about the green, yes? I know you; I know your father." Evidently, the justice of the peace had fought with Reinhard's father in World War One, and hence knew

\footnotetext{
${ }^{120}$ Helma Kroll, memoir, March 8, 2001. Book 1 p.9.

${ }^{121}$ Helma Kroll, memoir, March 8, 2001 . Book 1 p.9; Interview with Helma Kroll, June 20, 2005. p.4.

${ }^{122}$ There was also a religious ceremony, which was performed by a Lutheran minister, who Helma had known since she was young. In Germany, the civil service was mandatory, and the subsequent religious ceremony was optional.
} 
Reinhard's forester background. Helma recalls "for me, and also for my husband, this piece of the whole wedding was the best one."123

The 'reception' was similarly small, and again illustrated material shortages. Her mother had saved meat stamps in order to have five small rouladen for the 'feast.' "There was a cake made out of slices of bread [white - which had been gotten from the American side] and jam...and perhaps some vanilla sauce..." ${ }^{24}$ it was in celebration for both the wedding and the birth of a friends' baby. The gift was a white bed sheet which Helma's mother had managed to retain, with a metal, gold ribbon. Though not the typical wedding of bridal magazines, it is apparent in Helma's oral testimony that despite the dearth of material wealth, this was a very happy time.

The couple's honeymoon was also "not quite what a bride is dreaming of, but at this time, [the couple] accepted everything," a comment which both further helps to explain the Krolls' subsequent ability to manage in difficult circumstances, and also illustrates Helma's perpetually positive attitude. ${ }^{125}$ The newlyweds spent time both in the East and West; the voyage West being 'exciting' for Helma in its illegal nature. They were in the West for twenty-four days, of which only seven nights were in a 'proper bed.' As Helma recalls, "Most nights we were sitting in overcrowded halls on our knapsacks waiting for another connection....at that time most of the German people were still uprooted and looking for a new future. ${ }^{\prime 26}$ Her testimony both contextualizes the Krolls' place in time, and helps to remind the reader that during spring 1946, both Eastern and Western Germany were still largely in a state of disrepair. All occupying powers had been

\footnotetext{
${ }^{123}$ Interview with Helma Kroll, June 20, 2005. p.4.

${ }^{124}$ Interview with Helma Kroll, June 20, 2005. p.5.

${ }^{125}$ Helma Kroll, memoir, March 8, 2001.Book 1 p. 10.

${ }^{126}$ Helma Kroll, memoir, March 8, 2001. Book 1 p. 10.
} 
concerned with Germany's total defeat, and her ability to start another war. However, whereas in the West, British and American authorities recognized that Germany needed to be rebuilt, and would soon fund such an initiative through the Marshall Plan (1946), Soviet policy showed little such interest. In the beginning of their occupation, the Soviet government treated East Germany as a conquered state, not a future satellite. ${ }^{127}$ This approach was illustrated by the dismantling of German industry: it was an action that suggested a total disregard for Germany's long-term well-being (and thus suggests that Stalin's initial intention was not to make Germany's separation permanent), and reinforced the idea of revenge -taking for themselves what the Germans had taken from them during the course of the war. ${ }^{128}$ As Helma illustrates through her testimony, her honeymoon was not isolated from the occupation. She and Reinhard witnessed the result of such Soviet policy on their train ride back to Neu Glinicke: their train was missing windows, and the track was missing rails. ${ }^{129}$

Life as a forester's wife began for Helma in May 1946, when Reinhard was given a post in Colbitz. Helma's narration (in both her memoir and oral testimony) of her time as a forester's wife is based upon family and home; however, political pressures would compel their departure and intrude upon the private sphere. To a large extent, Helma's oral testimony is determined by the interview questions; nonetheless, the extensive overlap between Helma's memoirs and her oral testimony suggests that the interview's frame was not so remote from how Helma independently imagined her past. Although

\footnotetext{
${ }^{127}$ Fulbrook, The Two Germanys, p.13.

${ }^{128}$ Many assert that Stalin's intentions were that Germany would be reunited, and not continue to exist as a separate state. Fulbrook cites the turning point (or final proof otherwise) came in 1952. Fulbrook, The Two Germanys, p.17.Unofficially however, indications of a different policy, present. For example, in 1948, Stalin was reported to have said "The West will make West Germany their own state, and we shall turn East Germany into our own." Milovan Dijilas, Conversations with Stalin. (London: Hart Davies, 1962), p.119; as cited by Steele, p. 69 .

${ }^{129}$ Helma Kroll, memoir, March 8, 2001, Book 1, p.9.
} 
Helma's narrative explores many themes during this period, each operates within the scope of family; its growth, daily life, position in the community, and the way in which it was impacted by political tensions. Through this multi-layered account, the scene is set for understanding both why the Krolls left the East and what made migration particularly challenging for them. Above all, however, the narrative's reoccurring focus on family highlights Helma's past and present values: that her family was, and continues to be, a priority for her.

In Colbitz, Reinhard and Helma were installed in an apartment which was close to where the party boss lived. Yet they were still wary of the Russian soldiers: Reinhard protected the couple with a homemade security system which would electrically shock intruders. Their apartment contained furniture likely stolen by Russian soldiers, and even had mattresses -about which Helma says "we were lucky." ${ }^{130}$ The shortage of goods was very apparent: potatoes in numerous forms provided the main source of nourishment. In Colbitz, the district forester "was one of the remaining real Forest Masters, a wonderful man and boss;" this statement is significant because as the Krolls discovered, many skilled foresters came to be purged or demoted. ${ }^{131}$ Foresters were civil servants, and under the Communists, forest policy was increasingly ruled by politics, as opposed to skill or long-term 'green' policies. ${ }^{132}$ There was another forester under their boss's supervision, who was "lots of trouble" but "held the position for a long time and was not dismissed because for one or another reason he never was in the Nazi party." ${ }^{133} \mathrm{He}$

\footnotetext{
${ }^{130}$ Helma Kroll, memoir, March 8, 2001. Book 1 p. 10.

${ }^{131}$ Helma Kroll, memoir, March 8, 2001. Book 1 p. 10.

${ }^{132}$ Nelson, pp. 44-45. The USSR over-harvested East German forests dramatically during the occupation; this was part of their 'reparation payments.' Nelson, p.39.

${ }^{133}$ Helma Kroll, memoir, March 8, 2001. Book 1 p.11.
} 
needed to be replaced (he was subsequently shifted to another position within the district) and Reinhard became the forester of Forstamt Altenplatow, close to Genthnin.

At Reinhard's new post, the family lived in a large home with farmland and an orchard, which belonged to the Government. ${ }^{134}$ Though there was much more food due to the orchard and farm animals, Helma suffered the effects of the previous months' poor nutrition. In the summer of 1947 , she gave birth to "a very tiny little girl." Both she and her daughter were very sick. "Pregnancy was a great strain on whatever was available, so a baby wouldn't be healthy either."135 Though Helma survived with eight weeks of hospitalization, "poor nutrition during the pregnancy did not give [her daughter] a chance" and she died at six weeks. It would not be unusual for Helma, as a woman, to have sacrificed her own nutritional needs for other family members. This is a powerful example of inadequate nutrition; yet, significantly, it is only in relation to her daughter that Helma reveals her own want of food.

Because the Krolls lived in a large house, it had to be shared with others, including three refugee families from further east. Food continued to be central to Helma's memory of this period; its presence is in part framed by the resourcefulness with which the Krolls used it, in conditions of general food shortages. Helma and Kroll traded food for household goods, benefiting from the animals they (with the help of the coachman) tended and the crops they grew: a cow, pig, and potatoes, hay and rye. Nonetheless, one constant source of grief for farmers, which "hung like the sword of Damocles over [them]"—was the "Soll." ${ }^{\text {"136 }}$ Helma compares the Soll to a 'tithe.' Under the Soviet authorities a requisitioning and quota system was imposed upon workers and

\footnotetext{
${ }^{134}$ Helma Kroll, memoir, March 8, 2001. Book 1 p.11.

${ }^{135}$ Interview with Beate Myhill, June 20, 2005, p.3.

${ }^{136}$ Helma Kroll, memoir, March 8, 2001. Book 1 p.12.
} 
farmers alike. Producers had to give so much of their 'profit' to the state; if they did notfor whatever reason - they were liable to face 'draconian' fines. ${ }^{137}$ In this manner, many like the Krolls found that the State consistently encroached upon their efforts for success. When they purchased a cow, not only did they lose food stamps for milk and butter, but they also had to give the state its share. This could be difficult, as Helma writes

From the cow ' $x$ ' quarts of milk had to be delivered to the state for a very low price and also ' $x$ ' pounds of meat, which sometimes was difficult, if the cow did not produce a calf in that year. Same problems with a pig. Potatoes, wheat, went in a quota the same way. Even the labourers had a 'Soll' in hourly, daily or weekly production. If you could not make it, there was always a place in the jail or labour camp for you. The pressure under the Russian occupation was much tougher than ever under Hitler. ${ }^{138}$

Yet, there were some ways to avoid paying the 'Soll' which the Krolls utilized. For example, when in 1948 the cow did not have a calf, and thus failed to meet her 'Soll,' Reinhard traded in the cow for four goats, whose milk the state did not want. These goats went on to produce kids, who became "good trade subjects." Not all farmers in the Eastern Zone were so lucky; the harsh quotas that Helma alludes to could not be met by many, and moreover, the nationalization of farmland, would provide the impetus for a mass exodus of farmers in the future.

The quotas pertained not only to livestock but also to the workforce. Such human quotas would also contribute to Helma's growing household. The importance of family permeates Helma's oral testimony. In essence Helma's family was formed during these years, and it was really the only 'thing' she brought with her to Canada. The Krolls' lives revolved around each other. Helma stresses that family was her and Reinhard's priority from early on-and likely, as Helma aged, it became only more so. During this period,

\footnotetext{
${ }^{137}$ Naimark, pp. 158-161.

${ }^{138}$ Helma Kroll, memoir, March 8, 2001. Book 1, p.12.
} 
the Krolls built their family by both conventional and unconventional means. The Russians sent many East Prussian orphans to East Germany; and when she realized that she was pregnant again, Helma and Reinhard decided to adopt an older child to help Helma with the baby. They chose Erna, who "really was fourteen but looked like twelve, with a terrible little potato tummy."139 Erna and her brother (who would subsequently become a 'guest' at the Krolls') had lost their parents through the course of the war. Under the Soviet system, Erna had had to earn food stamps at a "Volksgut" (farm collective); because she and her little brother were considered a 'family,' she had to do the full labour of a man and wife. ${ }^{140}$

The family's second addition, Beate, was born in November 1948. Helma says of this period, "Even with all the work that was waiting, we four were a very happy family." Farm work was very demanding, but Helma had the help (and wisdom) of a nurse after the birth. She and her husband also socialized with other foresters, such as their 'neighbours,' Hubert Hundrieser and his wife Annelotte. At a distance of thirty kilometres, their relationship required some effort due to the short supply of gasoline, but it would prove to be a fateful friendship for both-as the Hundriesers later assisted the Krolls to migrate to Canada. However, even though "it was a very happy time, [it] was always shadowed by political hiccups."141 Helma explains: "The mayor and district director of Genthin both got their position because during the Nazi time they were in a concentration camp."142 Being against the Nazi regime during the war put them in better graces with the Communist Party. Political affiliation was a powerful springboard (or

\footnotetext{
${ }^{139}$ Interview with Helma Kroll, June 20, 2005. p.12.

${ }^{140}$ Helma Kroll, memoir, March 8, 2001. Book 1, p.13.

${ }^{141}$ Helma Kroll, memoir, March 8, 2001. Book 1 p.13.

${ }^{142}$ Helma Kroll, memoir, March 8, 2001. Book 1 p.13.
} 
barrier) to one's career, and party membership provided advancement and job protection. When the spring came "the political situation got wors[e]" for the Krolls; as Helma puts it, Reinhard "had quite a lot of trouble with the Communist party." ${ }^{143}$ Her daughter translates: "He refused to join the Communist Party which is not a good thing to do if you're working for the government." 144 Candidates for administrative positions were heavily screened with regard for their ideological beliefs, and employees who disagreed or dissented from the government risked the loss of their current employment, as well as future opportunities. ${ }^{145}$ If one was deemed connected to a dissenting voice then options to advancement were blocked. Political conformity was the key to personal and familial success; opposition, on the other hand, could prove detrimental to one's physical, economic, and social well-being. ${ }^{146}$ Reinhard therefore took a substantial risk by refusing to join the Party, one which would make his position, and his safety, increasingly tenuous. At this point, however, he was perceivably lucky: Reinhard was able to obtain a position in Schweinitz, "a different forest district which was a little bit sidelined and not mainstream." ${ }^{147}$ Presumably, Reinhard and his unauthorized views would be safer there, or at least, less noticed. However, this relief would be temporary. The party, its discrimination, and its demand for conformity would encroach more and more upon the Krolls' daily life. Though Helma's recollection of this period centres on family life,

\footnotetext{
${ }^{143}$ Interview with Helma Kroll, June 8, 2005, p.7.

${ }^{144}$ Interview with Helma Kroll, June 8, 2005, p.7.

${ }^{57}$ Henry Ashby Turner, Jr. The Two Germanies Since 1945 (New Haven: Yale University Press, 1987), p. 47.

${ }^{146}$ Dorothee Wierling states "The Party saw professional education and political training as a unit." Party membership was needed for even low career aspirations; for example, foreman on a shop floor. Wierling, "The Hitler Youth Generation in the GDR, Insecurities, Ambitions and Dilemnmas," In Konrad H. Jarausch, ed. Dictatorship as Experience Towards a Socio-Cultural History of the GDR.(New York: Berghahn Books, 1999), 317.

${ }^{147}$ Interview with Helma Kroll, June 8, 2005, p.7.
} 
political pressures repeatedly intrude upon the private sphere, interrupting an otherwise happy existence in the GDR.

The move to Schweinitz was tempered by Party restrictions, or, what also seems very likely, personal politics between Reinhard and the mayor. Moving the farm animals to another district was very difficult; Reinhard received inside knowledge that the mayor intended for his animals to be confiscated. Here, the family showed a great deal of courage: they hired a farmer to move the animals one hour earlier than the scheduled expropriation of their livestock. The mayor appeared at the scheduled time with policemen, but despite "some very tense moments...nothing happened."148 Evidently, the Krolls had 'tricked' the system, but as Helma would later say, 'the noose' was getting tighter.

After the move, the Krolls passed "nearly four very happy family years as forest people in Germany." 149 This period exemplifies some of the traditional aspects of both farm and forester life in Germany; it also contributes to an understanding of postwar German society under the Communist Party. The house at Schweinitz, was a 'gentlemen farm' with "a big garden and lots of poultry, chicken, geese, ducks and of course [their] goats and pig." 150 When Helma states that she did not 'work' during this period, she defines 'work' as outside, paid labour. ${ }^{151}$ However, Helma does recognize that she made a significant contribution to the household. As the housewife on a farm and the wife of the district forester, she had many responsibilities. In her memoir, this explanation comes as an introduction to Reinhard's family; however, in her oral testimony she also stresses the

\footnotetext{
${ }^{148}$ Helma Kroll, memoir, March 8, 2001. Book 1, p.14.

${ }^{149}$ Helma Kroll, memoir, March 8, 2001. Book 1 p.15.

${ }^{150}$ Interview with Helma Kroll, June 8, 2005, p.10; Helma Kroll, memoir, March 8, 2001. Book 1 p.15.

${ }^{151}$ Interview with Helma Kroll, June 8, 2005, p.10.
} 
status held by the forester and his spouse. Likely, this is due to Helma's realization that such a social structure does not exist in Canada to the same degree; as well, it helps us to understand part of the sacrifice entailed by migration to Canada. Traditionally, the forester's wife

had to know everything. She had to be a good housekeeper, a competent farmer's wife, a witty, well-educated hostess, and mostly a good wife and mother. Their circle of friends was only the colleagues in other districts and the neighbourly owners of estates. The critical eyes of the village were always watching as to how her flower and vegetable garden looked, and when somebody in the village was sick or injured, she was often the first one who was asked for help. ${ }^{152}$

Helma's household chores included 'everything' from laundry to the rendering of farm animals. ${ }^{153}$ The work was very time consuming, and the lack of technology likely made it more so. Helma was lucky that her husband was inventive - he created a hot water heater which was very convenient on the family's weekly bathing day. Nevertheless, events such as the 'gross Waesche' or big laundry, illustrate both the nature of hard work for which Helma was responsible, and the traditional gendered division of labour. Helma describes the 'event':

Came the day, women put their full energy in, and all the other family members tried to disappear. [Reinhard] mostly had business at the farthest forestry station. In the basement was a room with a stove, which had a [built]-in copper tub. It was damp and cold summer and winter. The day before the big day, all the laundry was separated -white and coloured and soaked in wooden tubs in cold water with washing soda. On the next day a fire had to be made early in the morning to warm up the water in the copper tub. [Then] the laundry had to be wrung out of the cold water and put into the copper kettle with soap and boiled for a longer time. In the meantime the worker got a good hardy breakfast. [Then] the work began. Laundry out of the kettle into the wooden tub and well scrubbed on the washboard... The room was full of steam and it was hard work. The whole procedure was repeated a second time. Afterward everything was well rinsed, wrung out and in the afternoon you would hang your clean laundry outside on the clothesline: everything well sorted, socks in pairs with the toes looking all to one side. A housewife or washerwoman was valued on how white the wash was and how

${ }_{152}^{152}$ Helma Kroll, memoir, March 8, 2001. Book 1 p.1.

${ }^{153}$ Interview with Helma Kroll, June 20, 2005. p.8. 
properly it was hung. Between all this work, you gave your help a good hardy lunch or they would not come back the next time. If the housewife had to do the laundry...the family knew, pea soup for supper. Later on everything but the socks had to be ironed. With the help of another member of the family, bed sheets (made from cotton or linen) would be pulled corner to corner to restore them to squared shape. This was done according to a system handed down from generation to generation, before they were ironed. ${ }^{154}$

Numerous inferences from this passage can be drawn. Practically speaking, laundry day was both physically exhaustive and time consuming, which is why clothing was worn for one week, and bedding was changed every four. Laundry was clearly within the female domain; though other family members are alluded to in this passage, they would likely be children -not the male head of the household. As Helma points out, the clothing's whiteness and laundry's neatness was symbolic of her success as a housewife. One has the impression that there was an expected standard which women were to meet, perhaps one in which they took a degree of pride. Moreover, though Helma worked throughout the day, her other duties did not cease: she still was responsible for feeding her family. There is also a sense of tradition within laundry day - the same, efficient routine was followed, "handed down from generation to generation." Socks lined up in a certain manner, clothing folded like so. Likely, a lack of technology was a contributing factor to the practiced-tried, tested and true-status quo.

Helma's account of laundry day also alludes to aspects of 'togetherness' in village and farm life. Even though Helma had a quasi-elite status as the forester's wife- as described in the previous passage--she was not spared from such manual work. Her recollection suggests a large degree of comradery and cooperation with the other women beside whom she worked. One speculates whether this memory is affected by her subsequent position in Canada as domestic help, in what became an inversed reality. A

\footnotetext{
${ }^{154}$ Helma Kroll, memoir, March 8, 2001. Book 1 p.17.
} 
more likely explanation, however, is that the women who worked for Helma in Germany were 'hired help' rather than domestics. ${ }^{155}$ Traditionally-especially in the rural economy, hired help assisted in household production, working on a more flexible basis in a mutually cooperative environment. ${ }^{156}$ In the context of late eighteenth (or early nineteenth century) American 'help' Christine Stansell's explains that "the middling housewife...worked alongside her servants in a relationship approximating that of masters and apprentices." 157 This is in stark contrast to urban accounts of domestic service, in which the 'domestic' was not only used to perform household duties (on her own), but her mere presence (and distance from her employer) was a status symbol as well. ${ }^{158}$ Helma's relationship with her workers seems void of this latter mistress/employee mentality, in which power inequalities are clearly manifested. Helma laundered the clothing alongside her help. She was the 'host' - the recognized head of the household operations on laundry day, but gave her helpers respect and recognized their agency. For example, she knew that her ability to feed her help would determine the quality of the help she would receive in the future; therefore, she had to treat them well.

It is curious that in many respects traditional life continued, even though Germany was in the midst of such tremendous change. Perhaps postwar Germany's most definable feature was its immense population of refugees. At the end of the war there were 3.5 million refugees in the Soviet Zone alone, in some cases constituting fifty percent of the local population. ${ }^{159}$ The refugees placed additional burdens upon the East German

\footnotetext{
${ }^{155}$ Faye E. Dudden, Serving Women: Household Service in Nineteenth-Century America (Middleton: Wesleyan University Press, 1983), p.7.

${ }_{156}$ Dudden, p. 12.

${ }^{157}$ Christine Stansell, City of Women: Sex and Class in New York, 1789-1860. (New York: Alfred A. Knopf, 1986), p.163.

${ }^{158}$ Stansell, p.159.

${ }^{159}$ Steele, p.55; Fulbrook, The Divided Nation, p.151.
} 
population; they exacerbated the housing shortage to a great degree, forcing many Germans to share the little available space. ${ }^{160}$ Shared accommodation occurred extensively throughout postwar Germany, particularly under the Communists, who had practiced requisitioning for decades in the Soviet Union. It was a hindrance for many Germans: a scarcity of resources (space and facilities in particular), and differences in culture, religion, and lifestyle could create strong tensions and aggravate existing prejudices between native Germans and refugees. ${ }^{161}$ The Krolls shared their large home with three refugee families, who had lost their homes due to their expulsion from the Soviet Union. This is somewhat ironic, given the experience the Krolls would later have as refugees themselves. However, Helma remembers shared living in Schweinitz as a very good experience, in what was a 'friendly' and 'dependable' atmosphere. Helma's testimony portrays a sense of family-like cooperation amongst the women who lived in the Kroll household, which could be equated with a sort of female community. In exchange for the help of one young woman (who lived with her parents upstairs), Helma taught her typing and shorthand in their spare time, which helped the young woman qualify for an office job. ${ }^{162}$ Indeed, Helma received more than physical help with tasks such as laundry day. These women served as a sort of substitute family; they were quite a bit older than Helma, and for the Kroll children, "replaced the grandparents they did not see too often." From them, Helma could also "get advice and help and sometimes [she] could give it." ${ }^{, 163}$ Even if the women were 'simple,' Helma's testimony indicates that they

\footnotetext{
${ }^{160}$ In 1946, there were $14,000,000$ households and 8,000,000 dwellings. C. Kleßmann, Diedoppelte Staatsgründung. Deutsche Geschichte 1945-55. (Gottingen 1982), pp. 39, ff. 52; J Kocka "1945: Neubeginn oder Restauration?" In C. Stern and H.A. Winkler, eds. Wendepunktedeutscher Geschichte 1848-1945. (Frankfurt 1979), pp.143-4, as cited by Frevert, p.256.

${ }^{161}$ Fulbrook, The Divided Nation, pp.151-2.

${ }^{162}$ Helma Kroll, memoir, March 8, 2001. Book 1 p.17.

${ }^{163}$ Helma Kroll, memoir, March 8, 2001. Book 1 p.16.
} 
were an important part of her daily life in Schweinitz. They "were good friends and helped each other," creating a close knit 'community' in one large home.

For the Krolls, these years "circled around the family," and included two more additions. The first was a byproduct of the war that Helma lightly refers to as Reinhard's 'war mistake.' 164 Gerd was a young boy from the Western Zone, whose single mother was having difficulty. Just before he came to spend his summer vacation with the Krolls (the last before he started school), he had been in an orphanage. Helma states "he had a much nicer childhood at our place than in the West." At the end of the summer, she suggested to her husband that they keep him, an offer which gave his mother substantial relief. ${ }^{165}$ This occurrence was typical of the pieced-together wartime family, which the Krolls had already experienced through the fostering of Erna. It speaks to the widespread poverty throughout postwar Germany, (including the Western zone-though conditions were improving there), and also points to the single German mother who, though not an aberration by any means, had a very 'tough time' given the return of family values and the male workforce following the war. ${ }^{166}$ It also points to acceptance, and corroborates the weight that Helma placed upon family. It is interesting that in her memoir Helma does not discuss forthrightly how Gerd came to be a Kroll. Though perhaps it is existing knowledge for the letter collection's intended readers, one is given the impressionperhaps for a reason - that he fit into the family immediately and seamlessly. Through her

\footnotetext{
${ }^{164}$ Interview with Helma Kroll, June 20, 2005. p.7.

165 Interview with Helma Kroll, June 20, 2005. p.7.

${ }^{166}$ Besides the obvious - the many women widowed with children as a result of the war--illegitimate pregnancies were very common particularly following the war. Between rapes by Russian soldiers, and the sexual relations of American troops [which for some women was for fun or frivolous material benefit, but for others was a survival mechanism- or an "extension of housework" to get food, money, protection (Heineman p.85)], there were numerous unplanned pregnancies. Though abortion rates were exceedingly high during this period, illegitimate children were common. Interestingly enough, single mothers in the FRG faced much more discrimination than those in the GDR. Heineman, p.236; Tröger, Women in Culture and Politics: A Century for Change, p.115.
} 
letters and oral testimony, there is little doubt that Helma thinks of Gerd as her own; only through direct questioning does she volunteer his 'origins.' The Krolls' second acquisition was garnered through more conventional means, and his arrival has much less vagueness surrounding it. Hartmuth was born December 30, 1949; just before his birth, Erna had left the family during the week to work in the village, and only returned 'home' on weekends. Thus, the Kroll family now consisted of five full-time members.

Schweinitz was a small village with traditional values. It was the Germany of old-holding superstitious beliefs and following time-honoured social conventions. Despite changing conditions under the Communist government, the Krolls were still accorded a high place of importance in the long-established social order:

The forest master in any sort of social setting in the village was the village leader. It was not only a position that was respected, but there were expectations made of the forest master's wife-you were a social icon. ${ }^{167}$

Though the Kroll children played with those of the coachman, the Kroll adults socialized with a more elite group. Reinhard was an important individual in the village: he was an employer, a man with education and relative means (even if officially owned by the state), and his position was traditionally very privileged. For the Krolls, socializing generally consisted of visits with friends - colleagues, or other foresters and their wives, and involved such activities as playing cards, drinking coffee and eating cake. ${ }^{168}$ Reinhard also hunted; the "Jagdschein" or hunting permit was a traditional form of privilege unique to foresters, one which he took advantage of with colleagues and in some instances, even Russian officers. ${ }^{169}$ One mark of the Krolls' station was their telephone. In 1950, twentynine percent of the population lived in communities less than 2000 ; only the political elite

\footnotetext{
${ }^{167}$ Interview with Helma Kroll, June 8, 2005, p.10.

${ }^{168}$ Interview with Helma Kroll, June 8, 2005, p.11; Helma Kroll, memoir, March 8, 2001. Book 1 p.16.

${ }^{169}$ Helma Kroll, memoir, March 8, 2001. Book 1 pp. 2,16.
} 
had phones. ${ }^{170}$ Because of Reinhard's position, the Kroll's house (or rather, Reinhard's office) was one of the three or four houses in Schweinitz with a telephone. The phone increased their importance and role in the community, particularly Helma's. In her testimony she stresses the elevated status she held in the village, perhaps to provide an understanding of the identity she and her husband lost through migration—as refugees and new immigrants. While Reinhard lost his high-ranked profession, as a new immigrant, Helma not only had to work, but she was also no longer a community elite. She uses her relationship with the doctor to emphasize this stature. Because the doctor of the district lived thirty kilometres away and "gasoline was very, very tight," he called her on several occasions to see if his expertise was really required. Helma had basic first aid training from her camp experience, and thus could be of service for minor medical emergencies. She was a judge of medical emergencies, recalling one instance, for example, when a refugee child was unconscious with what they later discovered to be meningitis. In this case, Helma told the doctor: "Yes, you have to come, you have to come." 171

Not withstanding that these years were relatively incident-free, "even here, [there] were off and on political stumbling wires." ${ }^{172}$ It is important not to divorce the Krolls' years in Schweinitz from the greater picture, for politics was ever a constant presence even if not acutely felt on a day to day basis. Helma recognizes that her readers might overlook this aspect of their life, and reminds them: "Remember, we still were in the

\footnotetext{
${ }^{170}$ In 1980 , this amounted to only $9 \%$ of the population-figures are not available for the 1950 s. Fulbrook, German History Since 1800, p. 423.

${ }^{171}$ Interview with Helma Kroll, June 8, 2005, p.11.

${ }^{172}$ Helma Kroll, memoir, March 8, 2001. Book 1 p.16.
} 
Russian Zone." ${ }^{173}$ In order to understand the series of events which were to govern the Krolls' future, it is helpful to have a more panoptic view of the GDR's political climate. This will require a brief tracing of the postwar political developments in East Germany from the occupation onwards.

Within the first year of the Soviet occupation, changes in the Soviet zone such as reforms to land, school, judicial, and police systems, had largely been the result of a denazification policy. ${ }^{174}$ During the initial occupation, although the Soviet administration appeared to slowly hand power over to the German Communist Party (SED), the reality was that the SED was akin to a puppet government, subject to the whims and dictates of its powerful neighbour to the East. ${ }^{175}$ As the hostility between the East and the West grew - through such events as the economic union between the British and American zones (1946), the Truman Doctrine (1947), the Stalin-Tito rift (1948), ${ }^{176}$ and the Berlin Blockade (1948-9)-the SED increasingly took on a Soviet character, and moved away from a 'German road to Socialism."' 77 Between 1946 and 1947, large numbers of former Nazis, members of the economic elite and bourgeoisie parties (such as the CDU and LDP) were arrested, and denazification camps were constructed. ${ }^{178}$ With the increasing East/West divide, a progressive paranoia emerged at the top, and changes imposed upon the GDR's population began to closely resemble a Soviet-styled ideological

\footnotetext{
${ }^{173}$ Helma Kroll, memoir, March 8, 2001. Book 1 p. 17.

${ }^{174}$ Henry Krisch, The German Democratic Republic Boulder: Westview Press, 1985), p. 7.

${ }^{175}$ Martin McCauley, The German Democratic Republic Since 1945 (New York: St. Martin's Press, 1983), p.12.

${ }_{176}$ Krisch, p.6.

${ }^{177}$ This was Anton Ackermann's phrase, declared in December 1945. It was endorsed at the German Communist Party's congress 19 April 1946. David Childs, The GDR: Moscow's German Ally. (London: University of Nottingham, 1983, 1988), p.18.

${ }^{178}$ Naimark, p.386; McCauley, p.22. Camp inmates were disproportionably bourgeoisie. In existence until 1950 , these camps held up to 200,000 prisoners, some of whom were deported to the USSR. It is unclear to what extent these camps genuinely served to denazify Germans, rather than serve an ideological, socialist purpose.
} 
indoctrination. In 1948, the SED itself was 'cleansed' of 'Titoists' and 'Zionists,' along with those who had spent the war years in the West. ${ }^{179}$ Though the initial targets of such campaigns were more elite, this paranoia began to infiltrate the general population. Enforced coercion and compliance within the SED coincided with the government's (in essence the party's) increasingly prominent role in the 'private' lives of its citizens: education, sports, media, leisure, church, and even trade unions towed the party line. ${ }^{180}$ Though discrimination had existed throughout the late 1940s, policy was crystallized in 1949 when the German Democratic Republic was officially formed. ${ }^{181}$ It was accompanied by a democratic constitution which closely resembled that of the FRG: ensuring the freedom of assembly, press, speech, religion, and the freedom to strike, emigrate, own and inherit private property. On paper, the institutional framework mirrored that of the Federal Republic's; however, practice was a much different matter the constitution's democratic appearance was only an illusion. ${ }^{182}$ The rampant discrimination which affected various sectors of society was just one confirmation of the GDR's true nature. For many, like the Krolls, discriminatory socialist policies took several years to have a serious impact on their daily lives; however, in combination with political persecution-which provided the immediate impetus to flee-prejudice with

\footnotetext{
${ }^{179}$ Krisch, p.9. The result of the purges was a $10 \%$ loss to SED membership, Scharf, p.9. Yet, as Fulbrook points out, these individuals were notably expelled and not murdered, as many of their counterparts were in other Eastern bloc countries. Fulbrook, Anatomy of A Dictatorship, p.33.

${ }^{180}$ Fulbrook. Anatomy of A Dictatorship, p.19.

${ }^{181}$ Fulbrook, The Two Germanys, p.12; The announcement was accompanied with a caveat that the state's establishment was simply an interim stage until Germany's reunification was realized; however, the Communist rhetoric which surrounded the proclamation suggested that the GDR's presence was intended to be more than short term. Turner, p.50. It is telling that in neither the announcement nor the minds of many GDR citizens (let alone Western nations) was the GDR viewed as a legitimate, permanent state. Krisch ,p.86.

${ }_{182}$ Tumer, pp. $51-2$. The only real difference in the GDR was that national resources were to be socialized right away.
} 
regard to employment and education came to be two important factors in their decision. ${ }^{183}$ It is important to recognize how interconnected discrimination was with political persecution; in some respects, they were so interrelated they could be regarded as the same. $^{184}$

As the GDR's separate identity was realized, the state proceeded with its ambition to create the 'new man' through the alteration of 'social consciousness. ${ }^{185}$ The school provided an essential training ground for good socialist citizens. This was reflected in new subject material-'Leninism' became an integral part of the curriculum at every level of schooling, from kindergarten to university. ${ }^{186}$ However, not everyone was entitled to education; just as the relationship between job security and political adherence was absolute, prejudice in education was also systematic. Teachers were hired based upon their political adherence; students, on the other hand, were assessed according to their parents' backgrounds. ${ }^{187}$ In a memoir, Maria Ritter states, "I overheard my family talk about not being wanted by the Communist regime in power since Father had not been a farmer or a valued factory worker. Their children would be sent to the university instead." 188 The state's goal was to equalize opportunities, yet, the GDR would never be a classless or egalitarian society. ${ }^{189}$ Education and high profile jobs were opened up to the

\footnotetext{
${ }^{183}$ Particularly in the first few years of the occupation, though party members certainly had an advantage in work appointments, many non-Communists were employed as technical experts and managers simply because they were needed and there were not enough loyal experts to meet the demand. Krisch, p. 8 .

${ }^{184}$ Discrimination was often entirely political or ideological. As has been also noted by historians, the blur between economic and political pressures was typical of the Communist system. Dornberg, p. 98.

${ }^{185}$ Fulbrook, Anatomy of A Dictatorship, p. 130

${ }^{186}$ Turner, p.47. Coinciding with Leninism was the squeezing out of religious training in schools which eventually led to Jugendweihe, the State's answer to religious confirmation, in 1954. Fulbrook, Anatomy of A Dictatorship, p.95.

${ }^{187}$ Fulbrook, Anatomy of A Dictatorship, p.131.

${ }^{188}$ Ritter, p.25. I have added the italics.

${ }^{189}$ Fulbrook, The Divided Nation, p.190. That being said, the GDR did successfully open up postsecondary education so that the working class was proportionately represented. In the mid $1950 \mathrm{~s}, 53 \%$ of University students were from the working class, in a population where $69 \%$ were of the same background. That is
} 
proletariat, but at the expense of the middle class and formerly-privileged. State-run universities discriminated against those who were not children of workers or farmers, and it became advantageous to have come from a "previously disadvantageous social background." ${ }^{190}$ For the Krolls, the East German government

was helping the working poor, but anyone who had a high school education and maybe university, got work as a ditch digger. [Reinhard] was an educated man, with [the equivalent of] a masters degree. It would be impossible for the children to go to highschool or to university. ${ }^{191}$

Gerd was ten when the Krolls left East Germany, and therefore nearing high school age. In her oral testimony, Helma cites the lack of educational opportunity as a major reason why the Krolls left. Given that observation, it is particularly conspicuous that in her written memoir, Helma scarcely mentions the educational concerns; instead, her focus is upon the political pressures. Perhaps this discrepancy is in part due to her audience: she is interviewed by a university student who obviously values education, and might be perceived as somewhat unaware of the political danger in Germany at that time. Alternatively, Helma could have felt that her memoirs' intended readers - her childrenwere sufficiently aware of their parents' stance on education but needed to know more of their birthplace. Evidently, both factors played an important role. The memoirs suggest that the Kroll children's future education was not the Krolls' primary motivation for leaving; however, in light of Helma's oral testimony, it was undoubtedly a factor. Political pressures determined the Krolls' date of flight; however, if such immediate pressure had not been present, it is likely that education would have later been a deciding factor in the decision to leave.

compared to the FRG, whose respective numbers were $4 \%$ in a population of $57 \%$ workers. Fulbrook, The Divided Nation, p.231; Fulbrook, The Two Germanys, p.61

${ }_{190}$ Ritter, p.25; Turner, p.102; Fulbrook, German History Since 1800, p.418.

${ }^{191}$ Interview with Helma Kroll, June 8, 2005, p.7. 
Political pressure and persecution coincided with open discrimination (illustrated above to a 'minor' degree through education). The trend in the 'Democratic' Republic was certainly clear: rights of the individual were overridden by those of the state and society in an increasingly determined manner. Propaganda of the 'Western threat,' the use of informers, and the loose definition of crime created an atmosphere of distrust and anxiety.

When the Krolls arrived in Schweinitz, they shared their home with three refugee families with whom they had amicable relations; however, after a few years of relative comfort, the Krolls "had to give up two more rooms" for a new family. Although they had "a good relationship with them...it was not too comfortable" - their new neighbour was a member of the People's Police. ${ }^{192}$ The notion of physical space, in terms of both physical and mental comfort, is evident here. In this instance, the theory that power can be exercised by control over space is applicable, as the Krolls' had little agency in defining their place which became an instrument of control. ${ }^{193}$ The state security police, or Volkspolizei, had been formed in the summer of 1945 in order to "install a durable link between the power center and the individuals" in "building a socialist state."194 The police were a type of 'mediator' between the government and the people, enforcing laws dictated from above. ${ }^{195}$ The definition of crime had been markedly expanded under the Communists. In a heightened political climate where slaughtering a pig or not registering

\footnotetext{
${ }^{192}$ Helma Kroll, memoir, March 8, 2001.Book 1 p.17.

${ }^{193}$ Michel Foucault, "Space, Power, Knowledge," interview with Paul Rabinow, trans. Christian Hubert, The Foucault Reader, Paul Rabinow ed. (New York: Pantheon, 1984), p.252 as cited by Sherene H. Razack, "Introduction," Race, Space, and the Law: Unmapping a White Settler Society. Sherene H. Razack, ed. (Toronto: Between the Lines, 2002), 10.

194 Thomas Lindenberger, "Creating State Socialist Governance: The Case of the Deutsche Volkspolizei," Dictatorship as Experience Towards a Socio-Cultural History of the GDR. Jarausch, Konrad H. ed. (New York: Berghahn Books, 1999), 126-7.

${ }^{195}$ Bessel, German History, 10 (1992), 293.
} 
a cow was now deemed a 'political' offence and could justify imprisonment, the Volkspolizei's daily duties made them a heavily politicized force. ${ }^{196}$ Moreover, it was not only the laws and their enforcement, but also the pursuit of 'criminals' which was destructive to the population's morale. "Paranoia became the modus vivendi of the Volkspolicizei...the 'class enemy' was at work everywhere!"197 The Volkspolizei intensified the suspicion and fear which pervaded society, and only increased it over time; their high degree of surveillance and their recruitment of spies from the general population created a fear of talking, even amongst the very young. ${ }^{198}$ Maria Ritter recalls that as a child, she was "often told not to say anything to anybody out of fear of being overheard and spied on by the Volkspolizei, the state police. People were arrested and sent to jail for saying something bad about the government." 199 One's future and even personal safety was increasingly precarious if not an open supporter of the SED.

Although the Krolls "got along very well" with their police-neighbour, his arrival was one in a series of events which made the Krolls feel like the noose was slowly closing in on them. ${ }^{200}$ As Helma explains, it felt as if "everything [got] tighter and tighter and tighter." ${ }^{201}$ For the Krolls, 'the beginning of the end' seems to have occurred when Reinhard reported the 'wrong' crime. ${ }^{202}$ At a nearby Russian military camp, the soldiers "were very poorly paid... and some clever ones found the wood which was for sale and they took it overnight and then sold it. [Reinhard] got into some trouble because they did it with their army wagons. [He] got the license and went to the commander, and reported

\footnotetext{
${ }^{196}$ Bessel, German History 10 (1992), 297.

${ }^{197}$ Bessel, German History 10 (1992), 299.

${ }^{198}$ Fulbrook. German History Since 1800, p.429.

${ }^{199}$ Ritter, p. 24.

${ }^{200}$ Interview with Helma Kroll, June 8, 2005 , p.9.

${ }^{201}$ Interview with Helma Kroll, June 8, 2005, p.9.

${ }^{202}$ Helma Kroll, memoir, March 8, 2001. Book 1 p. 18
} 
the theft." Protected by the safety of hindsight, Helma is able to laugh: "You d[id]n't do things like this." 203

The sequence of events which followed is somewhat unclear in both Helma's written memoir and the oral testimony of Helma and her daughter. Perhaps the murkiness is caused by the close temporal proximity of the events in question; in any event, I would argue that the importance of their order pales in comparison to the women's concurring opinion with regard to the decisive factors which spurred the Krolls' flight. If, however, an effort needs to be made for chronological accuracy, what likely provides us with the closest account of events is a written report of Reinhard's testimony at a refugee claim centre. This was the Krolls' application for status as political refugees, taken in September 1953 in West Berlin. Although it might be held suspect due to the obvious motives under which Reinhard testified, it was signed by Reinhard, and accepted by the Refugee board; it also is consistent with the testimony of his wife and daughter, and as such, it seems to provide us with a trustworthy account of events (in their correct sequence). The examiner recorded that Reinhard:

always refused to give into the pressures of the communist system. Despite the continuing pressure, he never joined the SED. His refusal resulted in transferals and demotion. He had to go through serious interrogations and warnings. At the end of 1952, during an interrogation, he was forced to make a commitment to agree to give political information on other persons. At that time he was not able to escape and attended some of the ordered meetings. By giving only general public views he avoided all possible personal information on persons and colleagues. The SED voiced their dissatisfaction with his reports, and since April 1953 he was not asked for new reports. Instead he was discharged from his position. New work-contracts, with not very favourable conditions, but which he had accepted, were cancelled in short order, and verbal agreements were later reneged upon with written refusals. ${ }^{204}$

\footnotetext{
${ }^{203}$ Interview with Helma Kroll, June 8, 2005, p.8.

204 "Political Refugee Claim and Acceptance," (no name given),Berlin, September 16, 1953. Translated by Helma Kroll, Book 1 p.65. The translation was reviewed by Bob Harris (January 2006), and found to be fairly accurate, although a paragraph was omitted.
} 
Reinhard's daughter states that her father "was not giving the information that [the authorities] were looking for when he was told to report on the activities of other people. [When it] was discovered that he was not telling [the authorities] what they really wanted to know, there were some interrogations at the house, with locked doors and guns fired, for 12 hours."205 Helma, who remembers the interrogations as having occurred "some days later' after Reinhard's report, states "The [Russian] commander came with an interpreter to our house. It was the evening, I had to close the window-shutters in the room and had to leave. These kinds of visits in 1952 and 1953 were dangerous."206 The officer left without Reinhard, but Helma recalls: "we knew that there was an end coming to it - that this can't go on."207 Though there was an extensive interrogation at this point, Helma is not certain about what was said. It was only much later when they were out of East Germany - perhaps in an effort to keep his wife safe - that Reinhard told her what was said at the second visit: he "had been 'recruited' to the Sicherheitsdienst, an organization to spy on other people, his colleagues, and report." 208

The use of informers was an important tool of the state in its conduct of population surveillance and pursuit of political dissenters. ${ }^{209}$ This method was a crucial component to the air of suspicion and paranoia which had infiltrated East German society. Reinhard was implicated in this system, however, he did not provide the authorities with the information they were looking for: "By giving only general public views he avoided

\footnotetext{
${ }^{205}$ Interview with Helma Kroll, June 8, 2005, pp. 8-9.

${ }^{206}$ Helma Kroll, memoir, March 8, 2001. Book 1 p.18.

${ }^{207}$ Interview with Helma Kroll, June 8, 2005, p.9.

${ }^{208}$ Helma Kroll, memoir, March 8, 2001. Book 1 p.18.

209 Though the Stasi was established in 1950 (Fulbrook, Anatomy of a Dictatorship, p.47), it only came to be connected with the state machinery in the 1970s and 80s. Lindenberge, Dictatorship as Experience Towards a Socio-Cultural History of the GDR., p.126.
} 
all personal information on persons and colleagues. ${ }^{, 210}$ For the time being, Reinhard continued his passive resistance in a climate which became only more dangerous for those like him. People would 'be taken' in the middle of the night, with no arrest warrant or explanation given to family. ${ }^{211}$ Often times, they just suddenly went missing. Helma recalls that "neighbours were disappearing. [One neighbour] was a blabbermouth, a complainer. He went to the post office to pick up the mail and he didn't come back. It was three years before his wife found out that he was in Siberia, and then, he was sentenced to ten years of hard labour in the Gulags. ${ }^{, 212}$ It was clear the government was cracking down at an increased pace, with severe punishment that echoed that of the Soviet Union.

Reinhard's persecution was not straight forward; it came mainly in the form of dwindling employment opportunities. He was not alone in his experience. The party expected foresters to conform to its ideology; when they did not meet expectations, many foresters would find themselves demoted or dismissed from their posts, at the expense of forest health (and in effect the rural economy). ${ }^{213}$ Once in the West, Reinhard would meet fellow foresters who had had similar experiences. ${ }^{214}$ The closing of Forstamt Schweinitz roughly coincided with Reinhard's run-ins with the authorities. Reinhard was a skilled forester; in the summer of 1952 he created a "very great invention" - a pump through

\footnotetext{
210 "Political Refugee Claim and Acceptance," (no name given) Berlin, September 16, 1953. translated by Helma Kroll, Book 1 p.65.

${ }^{211}$ Childs, p.28.

${ }^{212}$ Interview with Helma Kroll, June 8, 2005, p.12.

${ }^{213}$ Nelson, p.45. There were several factors to this: the Nazis had been very active in forestry, and promoted the image of the forester; foresters were seen to have a connection with Göring in particular. In addition, professional foresters were independent: they "implied an alternative authority in the rural economy and thus threatened the party's control." Nelson, p.44.

${ }^{214}$ Over 600 Prussian senior district foresters left for the British zone, where they would be unable to find work. Nelson is unclear as to what time period this is; however, given that the British zone had merged with the American zone by 1947, this would be in a period of less than 2 years. VEB Forstprojektierun, Der Waldfonds in der Deutsche Demokratischen Republik Ausgewählte Informationen, (Ausgabe 1986. Fruchtbarkeitszieffern, Sch.3.3, 1989) as cited by Nelson, p.45..
} 
which to administer pesticide. ${ }^{215}$ Therefore, despite his transgression "he still got a job...But it was reducing...tightening the noose." Though not expressly dismissed, Reinhard's new post in Torgau was a demotion. Soon thereafter, he was on the ministry's list for layoffs. Reinhard appealed and was sent to another district, which coincidentally his former employer had just left, to flee west. ${ }^{216}$ But at this point, Helma says "we realized that our stay in the East was limited." Given his skill as forester, Reinhard "could weather the professional pressure, but politically it got very difficult. We had no plan, but we knew we would have to be ready and prepared."217 Although Helma does not expand upon such discussions, because she employs the term 'we,' it suggests that in her memory this important decision was at least quasi-collaborative, one that had the family's interests at heart. Inevitably, the way she frames this story resembles an adventure novel, as it leads to a climactic decision which was both dangerous and life-altering.

Reinhard's political 'gaff' coincided with big changes which were occurring on a macro-level within the GDR. In July 1952, the $2^{\text {nd }}$ Party Congress of the SED declared that "the political and economic conditions, as well as the consciousness of the working class and the majority of workers, have sufficiently developed, so that the building of socialism has become the main task of the German Democratic Republic."218 The 'building of socialism' shattered hopes of German reunification and the GDR now fell directly in line with Soviet policy. ${ }^{219}$ Heavy industrial expansion took precedence over

\footnotetext{
${ }^{215}$ Reinhard's invention won him 3,000 DM.

${ }^{216}$ Helma Kroll, memoir, March 8, 2001. Book 1 p. 19.

${ }^{217}$ Helma Kroll, memoir, March 8, 2001. Book 1 pp.19-20.

${ }^{218}$ Resolution of the Second Party Conference, printed in Dokumente der Sozialistischen Einheitspartei Deutschlands (Vol. IV) (Berlin [East]: Dietz Verlag, 1954), p.73; as cited by Bruce, p.159.

${ }^{219}$ Despite Stalin's final overture for German reunification in 1952 (which was subsequently rejected by the West), the GDR had taken steps towards becoming a fully-fledged member of the Eastern bloc, complete with all the expected accouterments. This inclusion was cemented as time wore on with the Western-based creation of NATO in 1949 , the war in Korea, the rejection of the $2^{\text {nd }}$ 'Germany note' in 1952, and the
} 
the production of consumer goods, agricultural collectivization was to be fully enforced, the campaign against the church and Christians was resumed, and the few private companies who remained became the targets of discriminatory taxation. ${ }^{220}$ The effect was a further erosion in living conditions which only increased the discrepancy between those in the East and the West. The increase in political repression coincided with the new policy. The lasting remnants of 'democracy' waned as the judiciary was brought in closer alignment with the communist system. ${ }^{221}$ Attempts to combat the omnipresent threat of the 'enemy' resulted in more informants, and a set of laws which were extremely liberal in their application. ${ }^{222}$ Increasingly, any infraction could be construed as criminal activity, given the appropriate manipulation. In industry, 'criminal' trials ensued in which not meeting one's target was equated to sabotage The attack against 'class enemies' was waged both at ground level and in the public eye when show trials of party officials, other parties' members, farmers and intellectuals were held during the winter of $1952-3 .{ }^{223}$ In May 1953, the party under Ulbricht turned against one of its respected members, as the war against 'saboteurs, parasites, and traitors' escalated. ${ }^{224}$

Materially, the new policy was very hard on the population. Enforced collectivization created food shortages, in both the country and city. ${ }^{225}$ Even for Communist supporters, in 1950 the estimated worker's wage was only between 50 and $75 \%$ of pre-war levels. ${ }^{226}$ The population was asked to be patient, and have faith that signing of the European Defense Community Treaty by the Federal Republic's President Adenauer. Kopstein, p.35.

${ }^{220}$ Kopstein, p.35

${ }^{221}$ Bruce, p. 160.

${ }^{222}$ Bruce, p. 162.

${ }^{223}$ Bruce, pp. 163, 168; Fulbrook, Anatomy of a Dictatorship, p. 176.

224 Steele, p.84.

${ }^{225}$ Childs, p. 28.

${ }^{226}$ Turner, p.112. 
prosperity would come in the near future as a reward for the hard work they put forth in the moment. ${ }^{227}$ However, belief in the system waned, particularly in light of conditions in the GDR's very successful neighbour to the west, the FRG. Though most East Germans could not visit the FRG, they wrote and talked to Westerners, and heard Western broadcasts over the radio. ${ }^{228}$ As GDR rationing continued, FRG citizens enjoyed all the comforts of a booming economy due in large part to Western aid: new technology, consumer goods, purchasing power, an abundance of food (including the availability of such GDR rarities like citrus fruit and chocolate), a high personal income, and, of course, personal freedom. ${ }^{229}$ This was in stark contrast to the living conditions which pervaded the GDR. With opportunities severely limited, political repression undeniable, a weak economy, and little indication of future improvement, conditions in the GDR were not encouraging. There were thousands who thought like the Krolls: "West Germany was a heaven for us." 230

It is important to understand that the Krolls were not an isolated case. Large scale (illegal) emigration from the GDR had been occurring for some time, though it was not always regarded as harmful by the SED. Between 1949 and 1952, over 675,000 East Germans fled to the West and registered as refugees, constituting 3.5\% of the GDR's population in $1949 .^{231}$ At first, the Soviets viewed this emigration positively: it offered a

\footnotetext{
${ }^{227}$ Katherine Pence, Pain and Prosperity: Reconsidering Twentieth Century German History, p.137.

${ }^{228}$ In $1951,78 \%$ of a group of Eastern Zone refugees reported they had listened mainly to radio in the American sector while in the GDR. In 1954, 31\% mainly listened to this radio station, while $33 \%$ listened sometimes. In 1954 however, Northwest German radio captured the ears of $37 \%$ of the listener's radio time, whereas in 1951 it had been the main station of $6 \%$. Only $23 \%$ mainly listened to East German radio, with $58 \%$ listening sometimes. That said, before their flight, $62 \%$ of these refugees reported having listened to the Voice of America at some point, and stopped listening due to problems with reception. "East Zone Refugees Report on Their Radio Listening Habits," Public Opinion in Semisovereign Germany: the HICOG Surveys. Anna J. Merritt and Richard L. Merritt, eds. (Chicago: University of Illinois, 1980), 203.

${ }^{229}$ Turner, p.113.

${ }^{230}$ Interview with Helma Kroll, June 8, 2005, p.14.

${ }^{231}$ Turner, p.110.
} 
reprieve from high unemployment, housing and consumer goods shortages, while ridding the state of socialism's opponents. ${ }^{232}$ However, as emigrant numbers increased because of rising political and economic pressures, the Soviets and SED leadership became alarmed by the sheer number of emigrants and the high composition of young and able workers, which the GDR's economy desperately needed. ${ }^{233}$ In May 1952, responding to this flight, the SED 'secured' the border with West Germany using barbed wire, guard dogs, a border patrol, and a three mile deep 'no-man' zone, otherwise known as Sperrzone. ${ }^{234}$ In September 1952, a special commission was created by the SED to solve the emigration problem. It tried a multi-faceted solution: propaganda was used to highlight difficult living conditions in the West (refugee camps and unemployment) and to portray emigrants as villains and traitors, thus attempting to dissuade prospective emigrants. In addition, police were to analyze each case of Republikflucht including the emigrant's background and their possible reasons for leaving. ${ }^{235}$ Nevertheless, these efforts proved futile as Berlin remained a gateway through which to escape to the affluent (and free) West. Emigration continued as the economic effects of the 'building of socialism' were realized, culminating in March 1953 with the highest number of emigrants to date, despite Soviet and SED efforts to the contrary.

For the Krolls, the winter of 1952 was spent in preparation for the move west. They did not know when they would leave, but they knew the time was fast approaching. Reinhard was working in the North, and his family was separated from him. It was a

\footnotetext{
${ }^{232}$ Although the loss of scientists, technical experts, and police was never seen favourably. Corey Ross, Constructing Socialism at the Grass-Roots: The Transformation of East Germany, 1945-65 (New York: St. Martin's Press, 2000), p.83.

${ }^{233}$ Turner, p.110.

${ }^{234}$ In order to create this zone, residents were forcibly removed from their homes. Ross, p. 84. In some places, villages were actually split into two. Childs, p.29; Fulbrook, Anatomy of a Dictatorship, p.179. ${ }^{235}$ Ross, pp. 84-5.
} 
dangerous time, and it was crucial that neither Helma nor her husband give any indications of their plans, for it would not only endanger them, but those they loved. Very few people knew of the Krolls' intentions-only their respective parents and a pair of family friends - and even they did not know when the escape was to occur. Helma's memory about the period leading up to their desertion is foggy, perhaps because of the high-profile nature of the event, and all the stress and fear which surrounded it. Nevertheless, she remembers that she spent months packing clothing, pictures, and items of sentimental value, waiting for the final word to leave. These goods were smuggled to the West slowly: parcels were sent to Helma's mother via their family friend, who mailed them from various postal stations. Reinhard would write to Helma (from his post in the South), under the guise of needing such items as bed sheets or pictures; on her visits to him, she would take suitcases, and stop in Berlin, along the way. However, they had to use extreme caution in all these exercises, and still could not take too much out of the home: their foster daughter Erna still came home every weekend, nothing could look awry for if she knew about the flight "it could later put her safety in jeopardy.",236 The spring of 1953 brought what Helma calls 'the turning point' in the decision to go west. Their timing coincided with that of many other East German Flüchtlinge.

The westward flight of numerous East Germans was a strong indication of the populace's dissatisfaction with the Communist Regime. Though the exodus reached a peak in March, three months later an unprecedented display of social unrest was witnessed by Reinhard. He happened to be in Berlin during what is today regarded by historians as one of the two most important events in GDR history, that which became

${ }^{236}$ Helma Kroll, memoir, March 8, 2001. Book 1 p.20. 
known as 'the June 17 Uprising. ${ }^{237}$ Reinhard's report of the event would serve as the impetus for the Krolls' departure - since the uprising was an outward protest of the people's objections to the state government, its acknowledgment was a threat to the government's preeminence and therefore, its recognition was politically dangerous.

In brief, the causes of June 17 stemmed from the SED's new economic policy, particularly as it related to workers. As the party aimed to be more productive in industry, workers' norms were increased by $10 \%$. This coincided with an increased cost of living due to inflation. ${ }^{238}$ In May 1953, the Soviet leadership watched conditions in the GDR disintegrate as a result of the SED's 1952 policy. A combination of economic and political factors-intensified by the economic policy-compelled large sectors of the population, both urban and rural, to show their disapproval of the regime through mass emigration. In the first half of 1953, 225,174 GDR citizens emigrated to the West; in April alone, approximately 1000 refugees left East Berlin per day. ${ }^{239}$ The Soviet leadership told Ulbricht and the SED to pull the plug on the 'building of socialism' and to rescind the majority of measures. ${ }^{240}$ When the SED launched its 'New Course' on 9 June

\footnotetext{
${ }^{237}$ The other seminal event was the destruction of the Berlin wall in 1989. Fulbrook, Anatomy of a Dictatorship, p.171

${ }^{238}$ Food shortages became a reality as farmers abandoned their farms in droves due to collectivization-- By April $1953,40 \%$ of wealthier farmers had fled the GDR, abandoning 500,000 hectares of quality farmland in the process (SAMPO-BA, SED, NL 182/1077 as cited by Kopstein p.35). Food, health care, and public transportation costs increased, which essentially reduced the workers' wage by $33 \%$. Kopstein, p.36.; Inflation rose in part due to increased spending on defense and a lack of productivity in agriculture and industry.

${ }^{239}$ Ross, p.183; 11 April 1953. From Canadian Embassy in Bonn to Secretary of State Eternal Affairs. RG 76 Vol 821 File 552-1-51 part I.

${ }^{240}$ The New Course included a decreased investment in heavy industry with an increase in consumer goods production, the lifting of discriminatory taxes, the reopening of private businesses, the partial allowance of travel to the West for intellectuals' conferences, the granting of visitor visas to West Germans, the return of previously expelled students (who had been expelled based on religious discrimination), the removal of the anti-church campaign, the return of ration cards to the middle class, and the invitation (and incentives) of GDR emigrants to return, particularly farmers. Steele, pp.86-7.
} 
1953 , it veritably revoked a number of contentious statutes of the old policy; however, it made a fatal error when it neglected to remove the raised workers' norms. ${ }^{241}$

The population was bewildered by the SED's sudden change in policy and rumors about the Americans, the GDR borders to the west, and the state of the SED ran rampant. ${ }^{242}$ The workers, plausibly the group whose support was most needed by the GDR, were perhaps the most confused by this reversal; they, who had been successfully indoctrinated into socialist ideology — particularly as it pertained to the GDR's economy - now wondered what was truly valid. Ironically, the 'authentic' proletariat was essentially the only section of the population to whom no real concessions of any sort were made in the New Course. They voiced their discontent through job action. Though small scale protests and strikes appeared on 12 June, by 17 June mass demonstrations were widespread. ${ }^{243}$ What started out as isolated groups of workers protesting workers' norms, turned into a massive series of strikes and protests that involved large portions of the population which questioned the legitimacy of the regime in 272 cities. $^{244}$ By June 17 , workers had been joined by other segments of the population, and demands shifted from economic to political: demonstrators called for the removal of the workers' norms, reduced prices in state stores, the removal of agricultural quotas, the release of prisoners, free elections, the government's resignation, and the removal of zonal boundaries (ie: reunification). ${ }^{245}$ Worker dissatisfaction over a relatively small point had opened a

\footnotetext{
${ }^{241}$ Bruce, p. 171 .

${ }^{242}$ Fulbrook, Anatomy of a Dictatorship p. 181.

243 Bruce, p. 172.

${ }^{244}$ Christian F. Ostermann, Uprising in East Germany $1953:$ the Cold War, the German question, and the first major upheaval behind the Iron Curtain compiled, edited and introduced by Christian F. Ostermann ; editorial coordination by Malcolm Byrne. Produced in collaboration with The Cold War International History Project at the Woodrow Wilson International Center for Scholars. (New York: Central European University Press, 2001), p.xv. Kopstein, p.36.

${ }^{245}$ BA-P, DO $111 / 45,12$. as cited in Bruce, p. 199.
} 
Pandora's Box which the SED could not politically or physically close. On the morning of the $17^{\text {th }}$, East Berlin protesters numbered $25,000 .{ }^{246}$ Banners of 'we demand lower quotas' now read 'we are not slaves' and 'we want free elections. ${ }^{247}$ Both the SED and Soviet leadership were frightened as SED headquarters, party and army officials were physically attacked by angry crowds. ${ }^{248}$ It was at this point, 13:00 on 17 June, that the Soviets declared a state of emergency in Berlin. Not trusting the reliability of the GDR's own police force, Soviet troops and tanks were brought in. ${ }^{249}$ Martial law was imposed for disobedience, cars were overturned and set on fire, and bullets flared. ${ }^{250}$ However, by the evening, the Red Army had control over East Berlin streets; it was only through their presence that the uprising was dismantled. ${ }^{251}$

Reinhard had been in Berlin at the time of the uprising. When he returned to his post, "he described what he had seen [which] tightened the noose because he was seen as a political dissident." ${ }^{, 252}$ According to the Refugee Claim and Acceptance in Berlin, Reinhard refused to identify specific participants in the uprising, for whom the authorities searched. One can only speculate as to what else Reinhard reported; if he conveyed the scene of mass discontent and violence which he had witnessed to others, this testimony would have only been more damning to the SED, for it was recognition and proof of a rift between the government and the people: what at first had been an isolated economic

\footnotetext{
${ }^{246}$ Mike Dennis. The Rise and Fall of the German Democratic Republic 1945-1990.(Harlow: Pearson Education, 2000), p.66.

247 Steele, p.90.

${ }^{248}$ Kopstein, p.36.

${ }^{249}$ Fulbrook, Anatomy of a dictatorship, p. 184.

${ }^{250}$ Dennis, p.66.

251 Though Soviet troops had control of East Berlin on June 18, it took the Red Army 10 days to fully regain control in the mining regions. Cajo Brendl, The Working Class Uprising in East Germany June 1953 (Eschanges et Mouvement, 1982)p.25 as cited by Bruce Allen, Germany East Dissent and Opposition (Montreal: Black Rose, 1991), pp.28-29.

${ }^{252}$ Interview with Helma Kroll, June 8, 2005, p. 12.
} 
grievance became popular anti-Communist political resistance quelled only through Soviet force. ${ }^{253}$ Reinhard now warranted a close watch, and he was soon after approached by an employee, who told him "Mr. Kroll, I only want to tell you that I have to report about you." To this, Reinhard, who had already been 'recruited' (unsuccessfully) could honestly reply "Yes, and I have been ordered to report on your weekly activities.",254 Reinhard had seemingly been protected for some time by those around him, for he had retained a position of sorts. However, this was "another piece of writing on the wall" that indicated that the end was near. ${ }^{255}$ The final turning point came when the same defiant 'informer' delivered Reinhard the cryptic message: "I think it's time." 256

\footnotetext{
${ }^{253}$ Bruce, p. 199.

${ }^{254}$ Interview with Helma Kroll, June 8, 2005, p.8.

${ }^{255}$ Interview with Helma Kroll, June 8, 2005, p.13.

${ }^{256}$ Helma notes 'thank goodness [this individual] got sick and he wasn't there at the time we left." Likely, he would have been held responsible as an accomplice in the Krolls' escape. Interview with Helma Kroll, June 8,2005 , p.11.
} 


\section{Chapter Three: Crowded Waiting Rooms}

Between East Germany and Canada, the Krolls would spend fourteen months in transit' as refugees. Though brief in terms of the Krolls' chronological history, the refugee experience left deep and lasting impressions upon both Helma and her daughter, likely due to the sharp rupture it formed with their previous lives and the difficulties which it posed. When the Krolls closed their door in East Germany, they left their standing as social elites, abandoned their material wealth, and parted from the life they knew and people they loved. They gained physical safety through this process, but also made significant sacrifices. They became residents at two refugee camps: the first for a short time in the Western Zone of Berlin, the second, for a year, in West Germany. As refugees, the Krolls confronted a new reality; this experience would test them on numerous fronts. Their loss of status challenged their self-identity and was exemplified by a lack of material wealth, permanent employment and security. Their roles as husband and wife, man and woman, parents and children, were altered by their change in circumstance. Where before they had lived in large comfortable housing with domestic help, they now inhabited cramped quarters which deprived them of both space and privacy; they existed in a state of limbo in which they could only hope for the best because a return to the East was not an option. Their letters and oral testimony speak to the adversity endured; however, above all, they illustrate that the Krolls were resourceful and that they adjusted. Faced with the unknown, Helma and Reinhard made a determined effort to stay in contact with their past; moreover, despite lengthy delays and unexpected obstacles, the Krolls remained hopeful as they looked forward to starting again, as a complete family unit, in Canada. 
The Krolls' departure did not occur without a great deal of forethought and they prepared for their move over the course of several months. Nonetheless, in order to stay 'safe' and avoid suspicion, the Krolls' flight to the West was "very quick." Reinhard came to join the family for a "vacation," and the family left Schweinitz on August 23, 1953, "to visit the Grandparents in Joachimsthal;" however, rather than switching trains in Berlin and continuing North East, they went to the Western zone of Berlin instead. ' Helma writes:

this all sounds simple, but it was very hard for us to leave the house, friends and everything for the last time, and not to show any emotion. Until we were in West Berlin, we were in great danger. Somebody could have been suspicious, and we would have been taken from the train and arrested. If that had happened, we would have been sentenced to jail, and the children would have been placed in an orphanage or adopted out. $^{2}$

It was a very risky move, and although months of deliberation had preceded it, Helma states "We were mentally prepared, but you are never $100 \%$ mentally prepared." ${ }^{3}$ Berlin was essentially the "only gateway" through which Easterners could escape since the GDR's creation of the Sperrzone in 1952; and, this route was taken by nine out of ten East German refugees. ${ }^{4}$ Pedestrians did not need to pass through the same controls as vehicles and used the underground subway, which allowed them to bypass Russian soldiers. ${ }^{5}$ Nonetheless, it was dangerous. There was the very real threat of German

\footnotetext{
' The Krolls' escape was rather typical. A contemporary observer reported "the average escapee makes no spectacular escape. He simply packs a few belongings in a valise, tells his neighbour he is going to visit friends in or near the Soviet Sector of Berlin and travels to Berlin. Once in East Berlin he can travel to West Berlin and asylum about as easy as a New Yorker can travel from Times Square to Columbus Circle." Joseph Felming. European Edition of the Stars and Stripes, Wednesday, March 4, 1953. p.2..

${ }^{2}$ Helma Kroll, memoir, March 8, 2001. Book 1, p.20.

${ }^{3}$ Interview with Helma Kroll, June 8, 2005, p.11.

${ }^{4}$ Harold J. Grant, ICEM, "Report on Berlin," April 22, 1953.RG 26 Vol 127 3-33-13. The Sperrzone refers to the armed border which separated East Germany from West Germany; it contained only two checkpoints through which citizens could pass through. Henry Ashby Turner Jr. The Two Germanies Since 1945 (New Haven: Yale University Press, 1987), p. 108.Richard Lehm, "Settling The East Zone Refugee The Task Of A West German Reception Camp," The Times, Thursday, Aug 20, 1953; pg. 7; Issue 52705; col F.

${ }^{5}$ Felming, Stars and Stripes.
} 
informers - fellow passengers on the train who would take notice of anyone with too much baggage. In order to dispel such suspicion, each of the Krolls carried only a small handbag or knapsack; however, as Helma comments "until we were in [West] Berlin we were always in fear that someone smelled something and we would be removed from the train." 6

The Krolls were officially 'safe' once they reached West Berlin; nevertheless, their journey had only just begun. They spent the night at a friend of Helma's before registering as refugees the following day. Presumably, the Krolls went to No. 8 KunoFischer Street, referred to by a contemporary observer as "the best known address in Germany."7 This was the location of the West Berlin Registration Centre, where representatives of the Bonn government granted or withheld refugee status.

The Krolls were amongst many other refugees. In 1953, 331,000 people fled the GDR for the FRG; August was the 'slowest' month with 'only' 10, 857 admitted to West Berlin. ${ }^{8}$ The mass emigration included people from various strata of society who left for a diverse set of reasons; yet, all who were with the Krolls at the reception centre were attempting to receive recognition as refugees. ${ }^{9}$ Using World War Two as a reference point, the international definition of 'refugee' had undergone several changes by the time

\footnotetext{
${ }^{6}$ Maria Ritter's account also illustrates the extreme caution with which flight was executed. The children escaped in turns, carrying small bags, and using 'summer vacation' permits as their cover. Maria Ritter, Return to Dresden (Jackson: University of Mississippi, 2004), p.167.Helma Kroll, memoir (undated, 1999.) German Edition, Book 1, p 3 Translated by Bob and Inge Harris.

${ }^{7}$ RG $76801547-5-551$ pt. 1. Joseph Felming. European Edition of the Stars and Stripes, Wednesday, March 4, 1953.p.2.

${ }^{8}$ Martin McCauley, The German Democratic Republic Since 1945 (New York: St. Martin's Press, 1983), p.69; Turner, p.117. This number is based only on those who reported in W. Germany. RG 76821 File 5521-551 part 1.December 21, 1953 to Undersecretary of State for External Affairs, Ottawa; from the Canadian Embassy, Bonn, Germany. The year's total was 276, 644, according to this source. It is in conflict with McCauley's source, withholding the fact that he cites his numbers to West Germany and not Berlin. It is also imperative to note that only $90 \%$ of refugees sought refugee status with the West German number; therefore, numbers are bound to be skewed. The remaining $10 \%$ often went directly to friends or family. [RG26 VO1. 127 File 3-33-13. 22 April 1955 Robillard to Ritchie.]

${ }^{9}$ Admittedly, the educated middle class, and wealthy farmers were disproportionately high.
} 
of the Krolls' emigration. ${ }^{10}$ In 1943, the United Nations Relief and Rehabilitation

Administration (UNRRA) defined 'refugees' as those it would assist. That included:

those who had been obliged to leave their homes by reason of the war and are found in liberated or conquered territory; those displaced within their own liberated countries; those who are exiles in other countries because of the war and are found in liberated or conquered territory; those displaced within their own liberated countries; those who are exiles in other countries because of war and whose return to their homes in liberated countries is regarded as a matter of urgency; [and] those stateless persons who have been driven as a result of war from their places of settled residence in countries in which they are not nationals to return to those places..."

For the most part, this definition was in reference to the Displaced Persons which the UNNRA expected to materialize in large numbers following the war. In 1951, when the DP crisis had essentially drawn to a close, the definition of 'refugee' was again revamped, both for those who remained, and the increasing contingency of Iron Curtain refugees, such as the East Germans. After much debate, the 1951 Convention Relating to the Status of Refugees found a new, workable definition. ${ }^{12}$ Here, a refugee was classified as a person who:

...owing to well-founded fear of being persecuted for reasons of race, religion, nationality, membership of a particular social group or political opinion, is outside the country of his nationality and is unable or owing to such fear, is unwilling to avail himself of the protection of that country, or who, not having a nationality and being outside the country of his former habitual residence as a result of such events, is unable or, owing to such fear, is unwilling to return to it. ${ }^{13}$

For East German emigrants, proving oneself a legitimate refugee-according to given definitions - was extremely important. As will be examined below, the Krolls were

\footnotetext{
${ }^{10}$ Gerald E. Dirks, Canada's Refugee Policy: Indifference or Opportunism? (Montreal: McGill-Queen's University Press, 1977), p.3.

"UNRRA, Journal of the First General Council (1945), "Report of the Sub-Committee on Refugees and Displaced Persons," paragraph 5, as cited by Dirks, p.102.

${ }^{12}$ Note, Canada did not agree to this definition until 1969. Canadian officials felt that it would hinder their ability to deport refugees who were a threat to national security. Dirks, pp. 180-182.

${ }^{13}$ Originally, this definition applied to refugees who "As a result of events occurring before 1 January 1951 ..." were in the above stated position. United Nations High Commissioner for Refugees (Geneva, Switzerland), no.3 (June 1974): p.1, as cited by Dirks, p.4.
} 
able to prove that they were in sufficient danger to warrant classification as 'political refugees;' nevertheless, this was difficult. As Helma observed, the motivations of those at the receiving camp were not uniform. Gerald Dirks asserts that the essential difference between the economic migrant and political refugee is the reason for which they leave: the first to improve financial circumstances, and the second due to fear. ${ }^{14}$ In respect to East German refugees, historians, government officials, and contemporary witnesses alike, confirm that the line between economic and political motives was ambiguous. Wrote one Canadian official: "only a minority of refugees are able to show that they fled because they were suffering or threatened with, exceptional political persecution;" that being said, "under a regime such as exists in East Germany, it is not always easy to distinguish between political and economic discrimination." ${ }^{\prime 5}$ Refugees' reasons for flight were numerous: in response to the GDR's struggling economy, some individuals were attracted to the FRG's 'economic miracle,' in contrast to those who opposed the Communist system, feared the GDR's increasing repression (including the fall out from the June $17^{\text {th }}$ rebellion) or "long[ed] to save their children from being corrupted by Communist teaching. ${ }^{" 16}$ Others feared permanent separation from family and friends due to the perceived hopelessness of reunification, or were afraid of the prospect of future war (the Korean War began in 1950). ${ }^{17}$ Even amongst those who left for reasons of economic

\footnotetext{
${ }^{14}$ Nonetheless, Dirks points out that despite these differences, political refugees often shared "a desire for economic improvement." Dirks, p.6.

${ }^{15}$ RG 76821 File 552-1-551 part 1 November 24, $1955 \mathrm{f} / \mathrm{Cdn}$ Embassy .

${ }^{16}$ RG 76821 File 552-1-551 part 1. November 24, 1955 f/ Cdn Embassy; RG 76821 File 552-1-551 part 1.December 21, 1953 to Undersecretary of State for External Affairs, Ottawa; from Davis, the Canadian Embassy, Bonn, Germany; .Dr. Goedhart as cited by O.M. Green “Germany's Human Flood That Never Stops" in The Globe and Mail, Monday, March 9, 1953, p.6.

${ }^{17}$ John Domberg, The Other Germany (New York: Doubleday \& Co. 1968), p.95; RG 76821 File 552-1551 part 1.December 21, 1953 to Undersecretary of State for External Affairs, Ottawa; from Davis, the Canadian Embassy, Bonn, Germany. Mary Fulbrook, Anatomy of A Dictatorship: Inside the GDR 19491989 (New York: Oxford University Press, 1995), p.135.
} 
opportunity, most emigrants' motivations were coloured with political overtones. As one East German refugee stated, "No man whose forefathers have been sitting on a farm for hundreds of years will abandon it without urgent need."18

Regardless of the reasons for their flight, the new refugees (as opposed to the 'original' East European refugees who arrived immediately following the war) all shared the danger and risk which escape entailed. One Western observer commented that "Fear appears to cling to the shabby clothes of the escapees who fill the street before the building and every inch of space inside the building's narrow, white washed halls." The refugees at the centre had much at stake, having essentially "left everything behind except what fit into a small bag." ${ }^{19}$ Return to the Soviet Zone would be dangerous for many as they were now considered traitors to the state through their desertion; and, with their money valued at only one fifth of the West German Mark, they generally were in need of the rights which refugee status afforded them. ${ }^{20}$

\footnotetext{
${ }^{18}$ Richard Lehm, "Settling The East Zone Refugee The Task Of A West German Reception Camp," The Times, Thursday, Aug 20, 1953; pg. 7; Issue 52705; col F.

${ }^{19}$ Joseph Felming, "Fear Clings to Refugees from East" in the European Edition of Stars and Stripes, Wednesday, March 4, 1953. p.2 RG 76801 547-5-551 pt.1.

${ }^{20}$ It is interesting to note that the GDR welcomed East German refugees back; yet, there is some confusion as to whether or not these refugees were actually safe if they returned. Certainly, there was a minor movement Eastwards of Germans who moved back to the GDR, due to family obligations, threats against family, or failure on the Westem Eastern side and the like; however, it was minor in comparison to the Westward migration. In the five years preceding 1955 , approximately 100,000 Germans went to the GDR, but in the same time period, 1,300,000 went the other direction. (RG76 Vol 821 552-1-551-pt.1.) These returnees, particularly in 1955, were encouraged by a 'softening' of GDR propaganda. (Eugene Lyons. In AFRF News Bulletin, New York. "They Chose Freedom." Display Ad 5, New York Times. Aug 8, 1955. p. 6). Nevertheless, Helma and Reinhard were very afraid of being caught in their escape, and returning. I am inclined to believe that Reinhard and Helma's fear was justified. Perhaps this can be explained by the difference between political refugees and others. Political refugees status was accorded when there was "an immediate danger of life and limb or for the freedom of the person." (RG26 Vol 127 File 3-33-13. (FRG) Expellee and Refugee Law (From Davis at the Canadian Embassy to External Affairs) March 26, 1953 (Law read March 25, 1953)). In addition, given the Communist Party's track record in the USSR (particularly the repatriation of DPs), the GDR's message is suspect. (Walter Sullivan. "Drifters Among East Zone Refugees Pose Security Problem for Berlin; Some Are Known Communist Agents and Others Fled in Panic -- Political Fugitives Are Being Flown to West Germany," The New York Times. Jan 30, 1953. p. 5) This is further supported by reports of Communist propaganda which stated that "refugees are all thieves and misfits." (No author. "German Refugees Set New Record; 2,600 Registered in Berlin in One
} 
Upon first arrival at the receiving centre, the refugee underwent a medical examination and registration, $\mathrm{x}$-rays, and then an "investigation of the applicant's right to the emergency reception procedure." ${ }^{21}$ This was followed by "assignment to the emergency refugee camp," after which time the long process of investigation began. Police investigation, document consultation, political screening, and hearings were used as tools by the West German authorities to classify refugees under one the following categories: "Bona fide political refugees," "Bona fide refugees," "Unrecognized refugees," or "Prominent members of the Eastern Communist Party or government officials. ${ }^{22}$ Such classification presents an interesting contrast to those delineated previously by the UNNRA and the Refugee Convention. All German refugees were received as West German citizens; however, the Federal State government imparted different privileges dependant upon one's status. Less than ten percent of refugees were granted status as "Bona fide political refugees" or those "who are able to substantiate their claim that they had to flee owing to danger to their life or personal safety;" however, about sixty percent qualified as "Bona fide refugees," or those who "fled for valid reasons other than immediate danger to their life or personal safety." ${ }^{23}$ Those who received bona fide refugee status were entitled to greater assistance than unrecognized refugees, including free transportation to West Germany, housing, a work permit, a passport, and recognition as a Western German Citizen. A "bona fide political refugee" was also

Day, With Many More Awaiting Final Approval." Special to The New York Times, Feb 3, 1953. p.

6); Felming, Stars and Stripes.

${ }^{21}$ RG 26 VOl 127 3-33-13 April 22, 1953 Grant.

${ }^{22}$ RG 26 Vol 127 3-33-13. To Chief Operations Division, Ottawa from Chief CGIM Karlsruhe, Germany. February 5, 1953.

${ }^{23}$ RG 26 Vol 127 3-33-13. To Chief Operations Division, Ottawa from Chief CGIM Karlsnuhe, Germany. February 5, 1953. This figure is contested by Otto Bach, chief of West Berlin's social affairs, who stated that admission boards at camps were advised to accept $85 \%$ of East German refugees as bona fide, whereas before it had been $70 \%$. No author, "Curtain Flood Overflows 85 Berlin Camps" in European Edition of The Stars and Strips Wednesday, March 4, 1953. pp.1,16. 
entitled to benefits under the public civil service, insurance, pensions, and was given special priority for housing and employment; obviously, this was the ideal classification to attain. ${ }^{24}$ Yet, the process was lengthy and took weeks. While refugees spent their days jumping through bureaucratic hoops—attending interviews, subjected to background checks, and scurrying to find supporting documents and witness testimony —-they resided at one of West Berlin's overcrowded reception camps.

On the evening that they registered, Helma and Reinhard went to a receiving camp where they were to stay while the German authorities assessed their case. Refugee camps had originally been created for the seven to eight million displaced foreigners (Lithuanians, Balts, Ukrainians, Jews, etc) at the end of the War by the Allied authorities, through the UNRRA until 1947, and then the International Refugee Organization (IRO). ${ }^{25}$ By 1951, the IRO's mandate had finished and camps were run by the West German government that funded eighty-five percent of their maintenance, with help from international organizations such as the Red Cross, and private organizations such as the Ford Foundation, World Council of Churches, Lutheran World Federation, Young Men's Christian Association, American Friends Service Committee, all in addition to Swiss and Norwegian Aid. ${ }^{26}$ Though the camps had improved drastically since the immediate postwar years, in 1953 conditions were still less than ideal and received criticism from the press and foreign authorities. ${ }^{27}$ In April 1953, West Berlin had 88 refugee camps housing

\footnotetext{
${ }^{24}$ RG 26 Vol 127 3-33-13. February 5, 1953. To Chief Operations Division, Ottawa from Chief CGIM Karlsnuhe, Germany.

${ }^{25}$ Milda Danys, Danys, DP Lithuanian Immigration to Canada After the Second World War (Toronto: Multicultural History Society of Ontario, 1986), p. 42.

${ }^{26}$ RG 26 Vol 127 3-33-13: April 22, 1953 Grant; UN Pres Release "UN High Commissioner for Refugees calls for International Action to Help Berlin Refugees" Jan 30, 1953; Press Release from the UN Feb.25, 1953.

${ }^{27}$ It is important to distinguish between the previous DPS and the East German refugees, for circumstances were different, particularly because a conscious decision had been made to flee the homeland permanently.
} 
45,000 refugees, with plans to build more. ${ }^{28}$ They were vastly overcrowded, often consisting of former army barracks or old factories which had never been intended for such use. ${ }^{29}$ At one conference, the Director of the German Red Cross gave observers "an outline of the magnitude of the problem - thousands of refugees sleeping on the floornot enough clothes - not enough facilities to take care of sick children —not knowing from day to day how many refugees would have to be sheltered and fed, etc." ${ }^{30}$ Those recognized as bona fide refugees qualified for camp residence and free transportation to the FRG. The difficulty arose in transporting them out: by March 1953 authorities were able to airlift 1000 refugees on a daily basis, yet there was still a large backlog of recognized refugees plus new arrivals, whose numbers remained excessively high. ${ }^{31}$ It seems that when Helma and Reinhard arrived, conditions at the camp were moderately better, likely due to the fact that new arrivals had begun to dwindle after June. ${ }^{32}$ Helma remembers vividly how 'terribly tight' housing was, fraught with "misery, noise, dust and tension." 33 Though food was "good and plenty," conditions were very difficult. ${ }^{34}$ The

\footnotetext{
However, due to lack of secondary source material, a similar infrastructure and morale (particularly in terms of space), they are helpful comparison with which to compare the Krolls' experience.

${ }^{28}$ RG 26 Vol 127 3-33-13 Grant, April 22, 1953; RG 76 Vol 801 547-5-551 pt.1 no author, from the European Edition of The Stars and Stripes, Wednesday March 4, 1953, p.1

${ }^{29}$ In Danys' description of the DP camps, she states that in addition to military barracks, buildings which had been intended for military industry workers or even prisoners of war were also used, often halfdestroyed by bombs. Danys, p.43. No description of such buildings exist however, for this particular group of refugees; No author. "Eastern Refugees Pour Into Berlin; Western Officials Report Total Has Now Reached 200,000 -- Soviet Zone Curbs Travel" Special to Tram, The New York Times Jul 30, 1952. p. 1,4 (4).

${ }^{30}$ RG 26 Vol 127 File 3-33-13. Robillard to Chief Operations Ottawa. Re: Conference on Refugees held at Berlin City Hall, 3 February 1953, February 101953.

${ }^{31}$ Geographically, Berlin was surrounded by the GDR. According to Helma "because it was still at time where it was very dangerous to travel from Berlin to West Germany. The only safe way was to travel by air." (Interview with Helma Kroll, June 8, 2005, p.16.); RG 76 Vol 801 547-5-551 pt.1. Nathan J. Margolin. "Refugees Flood Berlin as Reds Tighten Grip" in Stars and Stripes. No date visible, but sent to Ottawa March 23, 1953.

${ }^{32}$ RG 76821 File 552-1-551 part 1. The Canadian Embassy, Bonn, Germany. to Undersecretary of State for External Affairs, Ottawa. December 21, 1953. In May 1953, 41,988 refugees were admitted to Berlin, compared to 10,857 in August.

${ }^{33}$ Helma Kroll to Richard and Elfriede Kroll, September 11, 1953, Book 1, p.22.
} 
sexes were segregated-"Only in exceptional cases [could] families be accommodated under one roof" - and for the first week, Helma was with the two younger children in a room with ten bunk beds, while Reinhard and Gerd were in a room for men. ${ }^{35}$ Although her mother's home offered a temporary and welcome reprieve when they were overwhelmed by the crowded environment, Helma and Reinhard took such a respite rarely: they were at the camp for a purpose, to get out. ${ }^{36}$

Initially, Reinhard and Helma spent a great deal of time "running from one office to another." They underwent numerous interviews and completed a substantial amount of paperwork while simultaneously trying to look after the children. Shortly after their arrival, in order to spare both parties stress, the Krolls moved their children to a Red Cross Kinderheim, a type of orphanage where parents paid to board their children. ${ }^{37}$ It is noteworthy that in her oral interview, Helma does not remember the separation well, particularly in comparison to her daughter. This presents an interesting contrast to Helma's contemporary writing, in which the weight of the decision is illustrated in a letter to Helma's parents-in-law. She expresses the pain it caused her, in an apparent attempt to justify it to them and perhaps herself, as well:

We are very lucky that all three are now in a beautiful Red Cross Kinderheim. There they will have fresh air, good food and a more regulated day and they don't need to feel the stress in which their parents are living in the moment... The house mother keeps a strict but loving atmosphere, and her helpers are very kind. We feel it can't be any worse than in our housing. We prepared the children before and they were all for it.... They will adjust well and they are out of the whole camp misery, noise, dust and tension. I thought it would be easier for us too-but I miss the children. ${ }^{38}$

\footnotetext{
${ }^{34}$ Reinhard Kroll to Richard and Elfriede Kroll August 29, 1953, Book 1, p.21.

${ }^{35}$ Richard Lehm, "Settling The East Zone Refugee The Task Of A West German Reception Camp," The Times, Thursday, Aug 20, 1953; pg. 7; Issue 52705; col F.

${ }^{36}$ Helma Kroll to Richard and Elfriede Kroll. October 20, 1953, Book 1, p.26.

${ }^{37}$ Helma remarks that "after the war, it was not uncommon for people to have to place their children." (Interview with Helma Kroll, June 8, 2005 p. 15.)

${ }^{38}$ Helma Kroll to Richard and Elfriede Kroll. September 11, 1953, Book 1, p.22.
} 
Though expressed as a mutual decision, one wonders how the decision to send away the children was decided within the marriage. Seemingly, Helma saw the kinderheim as a way to let her and Reinhard focus on the task at hand-obtaining recognized refugee status - while providing the children with an environment free from such worries and stress. Despite the practicalities, the choice evidently was not easy for her at the time. However, in her oral interview, she dismisses the decision as practical and done out of necessity. She has largely forgotten the pain it caused both herself and her children -in fact, it is only because of her daughter that the Kinderheim is brought up. ${ }^{39}$ For Beate the memory is still vivid; as a child, the separation was very distressing and she likely did not comprehend her parents' line of reasoning. Beate was separated from her older brother Gerd, who was kept in a home for older children. The one visit they had together made her and Hartmouth 'crazy' because of the absence and subsequent re-separation. Compared to Helma, who thought the kinderheim was "very good for all three" children, Beate's memories are much less pleasant. ${ }^{40}$ Food often serves an important function in 'life writing,' linking one to past experiences, particularly those painful. ${ }^{41}$ As Marlene Epp demonstrates, food's power as a motif is accentuated by cultural values and extreme deprivation. Its traditional connection to the family and its customary role in providing daily structure make it a prevalent theme throughout the memoirs and oral testimonies of

\footnotetext{
${ }^{39}$ Within the interview, it is interesting to note that Helma nearly skips over this entire period. However, Beate makes a point of discussing it. Interview with Helma Kroll and Beate Myhill, June 8, 2005, p.14. One could make the conjecture that the time spent in the Kinderheim is still a sensitive subject between Helma and her daughter. Evidently for Beate, the separation was very painful and frightening.

${ }^{40}$ Helma Kroll to Eleonore Scholz. October 23, 1953, Book 1, p. 27.

${ }^{41}$ Evelyn J. Hinz, "Introduction," Mosaic 24,nos. 3-4 (Summer-Fall 1991), vii, as cited by Epp, "The Semiotics of Zwieback: Feasast and Famine in the Narratives of Mennonite Refugee Women," in Sisters or Strangers: Immigrant, Ethnic and Racialized Women in Canadian History. Edited by Marlene Epp, Franca Iacovetta and Frances Swyripa, (Toronto: University of Toronto Press, 2003), p.316.
} 
immigrants. ${ }^{42}$ As Michelle Langfield and Pam Maclean have demonstrated in their study of Jewish child migrants, 'body memories' including taste, are often used to retrieve the past. ${ }^{43}$ In this context, that Beate links the kinderheim with food is very appropriate. She recalls

[The kinderheim had] cream of wheat pudding and rice pudding, you know, made with milk. My whole childhood I think after that, I could not eat those things. I still will not willingly eat cream of wheat or rice pudding. And everything was seasoned; the only seasoning available was cinnamon. So I refused to eat cinnamon for years. That was sort of my little traumatic result. When we were in the [other] refugee camp afterwards, as a five year old, I reverted to drinking milk out of a baby bottle. ${ }^{44}$

Separation from her family was traumatic and clearly Beate wanted to return to the safety and comfort of her infancy, which is illustrated by her switch back to the bottle. The kinderheim disrupted Beate's her sense of security, depriving her of those things 'familiar': home, family, and by extension, food.

The Krolls spent eight weeks in the camp at Berlin. During this period, Helma and Reinhard had to prove their refugee claim and officially adopt Gerd. Gerd's adoption was only blocked by bureaucratic entanglements. His biological mother consented to it, and once the Krolls were able to find a sympathetic official, Gerd became "a real Kroll." However, proving oneself a legitimate political refugee was much more involved. Primarily, the task was within Reinhard's sphere rather than Helma's; as the persecuted party, he was responsible "to get all facts on the table with recommendations, etc. from

\footnotetext{
${ }^{42}$ Epp, Sisters or Strangers, p.324.

${ }^{43}$ Michelle Langfield and Pam Maclean, "“But Pineapple I'm Still A Bit Way of': Sensory Memories of Jewish Women who Migrated to Australia as Children, 1938-9," in Speaking to Immigrants: Oral Testimony and the History of Australian Migration. Edited by A. James Hammerton and Eric Richards (Canberra: History Program and Centre for Immigration and Multicultural Studies, Research School of Social Sciences, The Australian National University, 2002), p.93.

${ }^{44}$ Interview with Beate Myhill, June 8, 2005 p. 15.
} 
the Western side. ${ }^{, 45}$ It is telling that there is a significant difference in how the letter collection presents this process, in contrast to how Helma conveys it in her oral testimony. In the latter, she sees its purpose as

to somehow verify that you were not a member of the SS, you were not Gestapo, and you were not a war criminal. Since you leave without all your documentation, it's difficult. You have to find people who knew you during the war, who are people of authority, who will testify on your behalf, who will verify what your role was. It was a matter of finding those people and making contact. ${ }^{46}$

Though in memory, Helma certainly recognizes the impact of Communist affiliation (and the necessary lack thereof) during the exam, it is significant that for her, the officials' central concern was the individual's affiliation to Nazism. This understanding is challenged by other evidence, such as a contemporary letter from her husband, the statement from Reinhard's testimony, and the process outlined in government recordsall of which stress an examination which investigated the individual's relationship to the Communist Party. However, Helma's conception is not entirely misplaced, for documents by a contemporary Canadian official state that the "political views or leanings of an applicant has nothing to do with his recognition as a refugee under the German laws. For example, a lesser Communist or follower could be granted refugee status under category two." ${ }^{, 47}$ One can deduce from this evidence that although German officials were ultimately concerned with what danger the German Communist Party posed to an individual's safety (ie: a genuine refugee), they were also interested in one's Nazi past. Helma's memory suggests that the interviews consisted of numerous inquiries into Reinhard's war history, which certainly would have impacted the degree of importance

\footnotetext{
${ }^{45}$ Helma Kroll to Richard and Elfriede Kroll. September 11, 1953, Book 1, p.22.

${ }^{46}$ Interview with Helma Kroll, June 20, 2005. pp.7-8. It is interesting to note that here, Canadian officials believe it relatively easy to prove oneself a bona fide refugee "from evidence already in the hands of the West German authorities or through supporting documents or information from other refugees, church leaders, etc." RG 26 Vol 127 File 3-33-13. Robillard to Chief Operations. 10 February 1953.

${ }^{47}$ RG 26 Vol 127 File 3-33-13., Robillard to Chief Operations, 10 February 1953.
} 
that she placed upon the Nazi connection within this process. It also provides an interesting foil to Canadian immigration clearance, whose primary purpose was to weed out Communists and other such 'subversives." 48

In a letter to his parents, Reinhard describes the process with the German authorities as "nerve-racking;" he explains that he and Helma "had many interviews with different bureaucrats, who had to do the footwork for the main committee, which will, after the final interview decide if we were really in danger and are political refugees." 49 As will be further discussed, it is noteworthy that Helma was involved in the interviews, given that it was her husband who was the object of interrogation. Both Helma's testimony and Reinhard's written records document her involvement. ${ }^{50}$ She explains that the investigation "sometimes made [them] feel like criminals;" "51 they underwent

around five different interviews, with only one person always. They were very negative against you: 'Do you really say the truth?' or 'What do you have behind it'? We weren't used to this. I think after the fourth interview, we complained to the person who interviewed us and said 'Why is there so much mistrust?

Though Helma states that things changed after their complaint, they still had to go to another board and testify again. Behind the scenes, it is likely that their story was "crosschecked with persons from the same locality or town," "correlated with reports already in the possession of local German authorities" or perhaps even "referred back to the central bureau for further information from the East Zone. ${ }^{, 53}$ Finally, on September 16, after a

\footnotetext{
${ }^{48}$ For example, see Reg Whitaker, Double Standard: The Secret History of Canadian Immigration (Toronto: Lester \& Orpen Dennys, 1987).

${ }^{49}$ Reinhard Kroll to Richard and Elfriede Kroll August 29, 1953, Book 1, p.21.

${ }^{50}$ Again, this is an interesting foil to interviews with the Canadian officials, who initially interviewed Reinhard alone.

${ }^{51}$ Helma Kroll, memoir. March 8, 2001, Book 1, p.22.

${ }^{52}$ Interview with Helma Kroll, June 20, 2005. p.8.

${ }^{53}$ In an unofficial "Report on Berlin," written by Canadian Immigration official Harold J. Grant, Grant continues by stating "It is well to remember that the German authorities in Berlin have overall information
} 
lengthy interrogation by a three-person refugee commission, supported by "witnesses and certificates of good conduct as a foundation" to the interview, the Acceptance Delegation found that "with all the disadvantages in his duties and despite political pressure, [Reinhard] stayed true to his beliefs and protected his colleagues and friends. Remaining in the [GDR] would have brought danger to him and his family." ${ }^{, 54}$ He was thus deemed to have "serious reasons to ask for acceptance as a political refugee" and was accepted as such. For Reinhard and Helma, this recognition was the necessary ticket for their new life. $^{55}$

Though they would have liked to stay in West Germany, job prospects in Reinhard's field were extremely limited. Despite preferential treatment as a recognized political refugee, the wait was eight years long, for most of the educated foresters had already left the GDR. ${ }^{56}$ Many were in the Western zone looking for work, and like Reinhard's former supervisor, were "not in a very satisfying position." 57

Like many other postwar immigrants, the Krolls applied to numerous countries for visas. As Helma explains "we wanted to build a new home... We tried Guyana, and thank goodness we didn't get it!" ${ }^{58}$ From the beginning though, the Krolls already had Canada in mind as their destination. Throughout the period at the receiving camp, they were in touch with Reinhard's former colleague and friend, Hubert Hundreiser. Hubert had

\footnotetext{
on events in the Eastern Zone, are in daily contact with informants for the West and can generally break an applicant's story if strong doubt exists." RG 26 Vol 127 3-33-13 Grant, April 22, 1953.

${ }^{54}$ RG 26 Vol 127 3-33-13. Magistrat of Greater Berlin. "Law on the Recognition of Political Refugees of September 30 1950" (anonymous translation); "Political Refugee Claim and Acceptance," (no name given) Berlin, September 16, 1953. translated by Helma Kroll, Book 1, p.65 (translation verified by Bob Harris).

55 "Political Refugee Claim and Acceptance," (no name given) Berlin, September 16, 1953. translated by Helma Kroll, Book 1, p.65 (translation verified by Bob Harris).

${ }^{56}$ Interview with Helma Kroll, June 20, 2005. Book 1, p.8 Nelson uses the term 'many' with respect to this group's departure. Arvid Robert Nelson. "Acid rain and romanticism: East German forestry, 1945-1989" (Yale University, 1998), p.45.

${ }^{57}$ Reinhard Kroll to Richard and Elfriede Kroll August 29, 1953, Book 1, p.21.

${ }^{58}$ Interview with Helma Kroll, June 20, 2005 p.11.
} 
previously immigrated to Canada, and encouraged the Krolls' immigration. In this respect, he acted as their link in a chain migration; and had in fact, aided the immigration of other German friends before the Krolls. During the 1950s, although many immigrants gained entrance through contract-labour schemes, the majority came through some form of sponsorship. ${ }^{59}$ Sponsorship was usually intended for immediate family members, however, for refugees, sponsorship guidelines were expanded. ${ }^{60}$ So long as the individual was of 'good character' and had the potential to succeed in Canada, they could be sponsored by a friend, relative, or agency in Canada. ${ }^{61}$ Between 1946 and 1962, approximately one quarter of a million refugees arrived in Canada. ${ }^{62}$ Whether as immigrants or refugees, the Germans used sponsorship much less than some ethnic groups, especially the Italians. ${ }^{63}$ As Ronald Schmalz states, despite large waves of German immigrants during the 1950s, a large-scale German 'chain migration' did not occur; only thirty-five percent were sponsored, and most Germans arrived as 'independent immigrants.' ${ }^{64}$ The Krolls were among the minority who were sponsored. Their friend, Hubert Hundreiser, filed paperwork in Canada on their behalf and made the necessary financial guarantees. Given that the Krolls' fare was loaned to them by a Canadian church (the name of which remains allusive in both the letters and Helma's oral testimony), it also appears likely that the Krolls benefited from Canada's Approved

\footnotetext{
${ }^{59}$ Avery, p.175.

${ }^{60}$ This is specific reference to Milda Danys' example of Lithuanian DPs; she uses her own family as an example. Her relatives were financially-guaranteed by a fellow Lithuanian couple, though unrelated. Danys, pp. 218-221.

${ }^{61}$ The Immigration Program: A Report of the Canadian Immigration and Population Study. Canada: Department of Manpower and Immigration, 1974.

${ }^{62}$ Kelley, Ninette and Michael Trebilcock. The Making of the Mosaic: A History of Canadian Immigration Policy. (Toronto: University of Toronto, 1998), p.337

${ }^{63}$ Franca Iacovetta, Such Hardworking People: Italian immigrants in postwar Toronto. (Montreal: McGillQueen's University Press, 1992), p.48; Ronald E. Schmalz. "Former Enemies Come to Canada: Ottawa and the Postwar German Immigration Boom, 1951-1957," PhD dissertation. (Ottawa: University of Ottawa, 2000), 121 .

${ }^{64}$ Schmalz, p. 123
} 
Church Program (ACP) which was set up in $1953 .^{65}$ This program allowed certain church organizations to place specific immigrants at the top of the long Canadian Immigration waiting list. Conceivably, with the help of Hubert Hundreiser, the Krolls' immigration was made a priority through such an operation; nevertheless, the immigration process was still lengthy. Reinhard and Helma did not leave Berlin for West Germany right away; Reinhard had applied for a Canadian visa and his first interview with the Canadians was in Berlin on September 28, 1953. The family hoped to be on the last ship of the year, set to sail October $25,1953$.

That immigration to Canada was even an option for the Krolls was the result of the restoration of German migrants to preferred status in Canadian immigration policy. As of September 14, 1950, Canada's gates were once again open to German nationals when an Order-in-Council (P.C. 4364) removed them from the list of prohibited enemy aliens, ${ }^{66}$ and placed them "in a favourable position as compared with the citizens of any other countries except France, the United Kingdom and other Dominions, and the United States. ${ }^{, 67}$ Both in practice and policy, Canadian immigration was traditionally discriminatory, with an established bias against those who were perceivably different in terms of ethnicity and cultural customs. Though some exceptions had applied in order to

\footnotetext{
${ }^{65}$ Kelley and Trebilcock, p.338.

${ }^{66}$ It should be noted however that ethnic Germans were brought to Canada before this time beginning in 1947, as part of Canada's need to meet its labour shortage as well as address the humanitarian refugee crisis in postwar Europe.[Note, Whitaker, p.189, stresses that the Canadian government's efforts to help towards the refugees were overwhelmingly motivated by economics and politics.] This was in large part due to efforts by the CCCRR, an organization which would be instrumental in the immigration of German nationals a few years later. [Schmalz , p.57; Leibbrandt, p. 280]. It should also be noted that here, 'German nationals' applied to West Germans, rather than those in the Eastern Zone; This Order-in-Council revoked PC1606 (March 28, 1950) which had allowed for very limited German migration, but still had "the effect of depriving Canada of substantial numbers of German immigrants whose professional, technical or industrial skills would be a valuable asset to the national economy." RG 26 Vol 127, File 3-33-13. Memorandum to Cabinet, August 181950.

${ }^{67}$ RG 76 Vol 948 SF-C-1-1 (part 1) "Memorandum to the Cabinet Committee on Immigration Policy." 26 April 1949.
} 
facilitate large scale agricultural settlement, policy was geared towards those of Anglo-

Saxon and North European descent. ${ }^{68}$ Such discrimination was confirmed by a speech by

Prime Minister McKenzie King in 1947, which outlined an immigration policy that

would:

foster the growth of Canada by encouraging the admission of suitable and desirable immigrants in such numbers as can be readily absorbed into the Canadian economy without altering the fundamental composition of the Canadian population. $^{69}$

Canada's postwar immigration policy continued to abide by King's principles and was

fuelled by Canada's recent economic boom. Canada's insatiable need for labour attracted approximately two million immigrants in the fifteen years following the war. ${ }^{70}$ Canada joined in the "international scramble for labour; however, whereas during the immediate postwar years the DP camps had offered a rich labour source, by the early 50 's, "the days of pick and choose under too severe a criteria [were] gone." ${ }^{.71}$ Initially, German immigrants were banned given that they were a former enemy. Nonetheless, they fit the government's ethnic profile and could help meet Canada's labour needs. Germans had a long tradition as successful immigrants and in previous years, had been a preferred

\footnotetext{
${ }^{68}$ During the interwar period significant numbers of ethnic Germans settled as formers in large blocks in Western Canada. Rudolph A Helling, Jack Thiessen, Fritz Wieden, Elizabeth and Kurt Wangenheim, Karl Heeb. A Socio-economic History of German-Canadians: They, Too, Founded Canada. Edited by Bernd Hamm. (Wiesbaden: F. Steiner, 1984), p.58.

${ }^{69}$ RG76 Vol. 821, File 552-1-551 part 1. Fortier to Chapdelaine. March 31, 1955.

${ }^{70}$ M.C. Urquhart and K.A.H. Buckley, eds. Historical Statistics of Canada (Toronto: MacMillan, 1965, 1971), p.23.

Between 1939 and 1962, the nation's gross national product grew from $\$ 5.7$ to $\$ 36$ billion; ${ }^{70}$ between 1946 and 1955 alone, the real gross national product had increased by $41 \%$. Ninette Kelley and Michael Trebilcock. The Making of the Mosaic: A History of Canadian Immigration Policy (Toronto: University of Toronto, 1998), p.i; RG 76, Vol. 821.Press Release (FRG), 1 February 1956.

${ }^{71}$ Catherine Panich, Sanctuary? Remembering Postwar Immigration (Sydney: Allen \& Unwin, 1988) p. 16 as cited in Sauer, Immigration and Ethnicity in Canada: selected proceedings of the 22nd Annual Conference of the Association for Canadian Studies held at the Université du Québec à Montréal, 7-9 June 1995, p.161.RG76 Vol. 821, File 552-1-551 part 1.From Robillard (CGIM Karlsruhe) to Chief Operations Division, Ottawa. December 9, 1952.
} 
immigrant group. ${ }^{72}$ The new 'Cold War psychology' also became an important influence upon immigration policy and helped to displace enmity. ${ }^{73}$ With the intensification of antagonism between the East and the West, Communism replaced Nazism as the primary threat, and hostility towards Germans, both official and unofficial, markedly diminished. ${ }^{74}$ Aided by lobby groups who had successfully facilitated the immigration of Volksdeutche in the immediate postwar period, these reasons compelled the Canadian government to remove German nationals from the enemy alien list in 1950. In the following decade, more than a quarter million German nationals immigrated to Canada, comprising eighteen percent of Canadian immigrants during that decade. ${ }^{75}$ Though Canadian government records do not statistically discriminate between East German refugees and West German residents, we can presume that a number of such refugees, like the Krolls, found their way to Canada. ${ }^{76}$

Originally, the Bonn government had been receptive to an all-encompassing German emigration; however, by the mid-1950's, it veered away from a broad emigration (particularly of young men) and directed Canadian officials towards the available surplus

\footnotetext{
${ }^{72}$ In the early 1950s, Germany had an abundance of unemployed workers, particularly amongst the East German refugees. RG26 Vol. 127 File 3-33-13. T.C. Davis, Canadian Mission to Deputy Minister of Citizenship and Immigration, regarding meeting with Oberdürgermeister Reuter. Although this was changing with regard to the general population by the end of 1952, T.C. Davis October 31, 1952. RG76 Vol 948 SF-C-1-1 p1.1 Walter Harris, Memorandum to Cabinet. February 21, 1952 ${ }^{73}$ See Whitaker, Double Standard and Hawkins Canada and Immigration, p.29.

${ }^{74}$ Here it is also important to remember Canada's Gouzenko affair of 1946; this spy ring affected Canada directly and aroused fears and anxiety of the Red Threat. Kelley and Trebilcock, p.342. Howard Margolian, Unauthorized Entry: The Truth About Nazi War Criminals in Canada, 1946-56 (Toronto: University of Toronto Press, 2000) Margolian cites the crushing of the Czech Independence (March 1948), the Berlin Blockade (1948-9), the Korean War (June 1950) and the Communist take over of China (Fall 1949) as key events leading up to the shift. This also coincided with the FRG's rehabilitation of war criminals. Margolian, pp. 161-2. That being said, Canada's doors were in practice really open to those Germans in the FRG, for that was where Canadian immigration offices were located.

${ }^{75}$ Gerhard Bassler, "Germans," Encyclopedia of Canada's Peoples. Paul Robert Magocsi, editor. (Toronto: Published for the Multicultural History Society of Ontario by the University of Toronto Press, 1999), 597.

${ }^{76}$ Nor does the Canadian government differentiate between ethnic Germans and German nationals. Bassler, Encyclopedia of Canada's Peoples, p. 597.
} 
found in the refugee camps. The reality was that the government had appealed to Canadian authorities for some time to consider this group, and often used West Germans as enticements for the arranged immigration of the refugees. ${ }^{77}$ Following a meeting with German officials, Robillard, Chief at the Canadian Government Immigration Mission in Karlsruhe, summarized that "The German authorities are quite willing to do everything possible to give us farm workers but it is unlikely they will play ball with us unless we accept Eastern Zone refugees." 78 As the refugees increased in number and the FRG's economy picked up alongside its new military body, the Bonn Government became ever less willing to facilitate the emigration of West Germans; however, they were all too eager to be rid of the burdensome refugee contingent - both recognized and unrecognized. ${ }^{79}$ The presence of the refugees was very hard on the FRG, particularly in the early 1950 s. ${ }^{80}$ Though the Bonn government accepted them and looked after their welfare, the neo-refugees exacerbated the existing housing shortage, so much so that even when they found work they often couldn't stay because they had nowhere to live. ${ }^{81}$ The

\footnotetext{
${ }^{77}$ RG76 Vol. 821, File 552-1-551 part 1. February 27 1953; March 16, 1953, Robillard to Chief Operations, Davison; December 16, 1954. This is particularly true as the German economy began to boom. In a meeting with Von Schmoller, Robillard observed that "It is clear that German authorities will not want any action taken by us which will create the impression that they are actively engaged in recruiting migrants for Canada; excluding the refugee farm families whose migration they are interested in facilitating." October 4, 1955. From Chief CGIM Karlsruhe to Chief Ottawa. RG76 Vol. 821, File 552-1-551 part 1. Canadian officials were aware of this trend by 1952. February 21, 1952 Walter E. Harris, Memorandum to the Cabinet. RG76 Vol.948 Sf-C-1-1-p1.1

${ }^{78}$ RG76 Vol. 821, File 552-1-551 part 1 Robillard to Chief Operations, Davison. February 27 1953. It should be noted that the German government was also very concerned about Canada allowing the migration of married farm workers and their families, not just single labourers. RG 76 Vol 821 File 552-1-551 part 1. President of Landesarbeitsamtes Niedersachsen to Canadian Government Immigration Mission May 7 , 1952.

${ }^{79}$ RG76 Vol. 821, File 552-1-551 part 1. From Robillard to Chief Operations Canada re: meeting with Von Schmoller and Vesseym. April 41955.

${ }^{80}$ Some officials believed that this was part of a Russian effort to "impose additional burdens on the Federal Republic." RG 76 Vol 821 File 552-1-551 part 1.1 Canadian Embassy in Bonn to Secretary of State External Affairs. Regarding conversation with Dr. Von Schmoller, officer in the Political division. April 1 1953.

${ }^{81}$ RG 76 Vol 821 File 552-1-551 part 1.1Canadian Embassy in Bonn to Secretary of State External Affairs. Regarding conversation with Dr. Von Schmoller, officer in the Political division. 1 April 1953.
} 
FRG was overcrowded: in June 1953, it had 199 inhabitants $/ \mathrm{km}^{2}$ in comparison to 159 inhabitants in $1938 .^{82}$ Unemployment amongst refugees was particularly high, and the financial burden continued to increase as more East Germans came through Berlin to stay in the West. Following a conversation with Berlin senator Dr. Hertz, Canadian official W.F. Stone observed that Hertz opposed German emigration (specifically from Berlin) because "Canada wants only Berlin's best people - -the people [Berliners] don't want to lose...these objections don't apply, however, to the emigration from Berlin of Soviet Zone residents." 83 In particular, this included "thousands of bona fide farm workers" who could meet Canada's agricultural needs. ${ }^{84}$ Canada became willing to accept these refugees likely due to the unavailability of others. ${ }^{85}$ In addition, some Canadian officials, particularly those in External Affairs, had already urged "speedy action" towards them, lest the Canadian Government "lose the best immigrants available [in Europe] for years." $" 86$

Although refugees from Eastern Europe made a positive contribution to the Canadian labour force, their immigration was problematic for some within the government. They were subject to much suspicion; within their ranks, Soviet spies could slip through the authorities under the guise of a political refugee and threaten the nation's

\footnotetext{
${ }^{82}$ RG 76 Vol 821 File 552-1-551 part 1. speech by Mr. Storch, Minister of Labour of the FRG at the $36^{\text {th }}$ General Conference of the International Labour Organization. Translated. 18 June 1953.

${ }^{83}$ RG76 Vol. 821, File 552-1-551 part 1 W.F. Stone regarding a 1955 conversation with Dr. Hertz, a Senator of Berlin. As such, by the mid to late 1950s, the Canadian Government was prohibited from directly advertising; only indirect advertising such as newspaper articles, films, lectures to students, and interviews were prohibited. "Summary of Immigration Policies and Procedures for Info of New Minister of Citizenship and Immigration" by Administration Division. June 301957.

${ }^{84}$ RG76 Vol. 821, File 552-1-551 part 1. Robillard to Chief Operations, Davison. February 271953.

${ }^{85}$ What most be noted here is the competition for immigrants which Canada faced with Australia. Also, Canada was seemingly two-faced about its attitude towards German refugees. RG26 Vol 127 File 3-33-13. J.A. Sharrer to R. Lamarre. December 4, 1950.

${ }^{86}$ RG76 Vol 801 547-5-551 pt.1. Canadian Ambassador to Secretary of State External Affairs, February 12,1953
} 
sovereignty. ${ }^{87}$ In the immediate postwar period, although Canada played an active role in the UNRRA and the IRO, Canadian immigration officials were reluctant to open their gates to Eastern Europeans for these reasons. In fact, in 1951 the Canadian Government chose not to adopt the UN's International Convention Relating to the Status of Refugees because the RCMP deemed it might interfere with Canada's ability to deport refugees for reasons of security. ${ }^{88}$ Canada's postwar immigration practices were shaped by a combination of economic and security interests. This was reflected in officials' treatment of (and reluctance towards) Iron Curtain refugees, including the East Germans. Although the tide turned so that by 1955 , Robillard could state to German officials that

Refugees from the East Zone of Germany who have been granted full refugee status by your government are immediately eligible for migration to Canada. Those who are recognized merely are also eligible if they have been in the Western Sector of Berlin or West Zone of Germany for at least two years ${ }^{89}$

— such a statement did not come about overnight, and was the result of much interdepartmental dispute (and a continued need for labour). The East German refugees were considered a problematic contingent in terms of immigration security, and thus, before they could enter Canada on an equivalent footing to other potential immigrants, agreement on how to adequately address this security risk had to be reached.

Reinhard's immigration experience gives some insight into the security procedure which East German refugees had to undergo; however, because Helma most often wrote the letters, they do not provide much detail. It is therefore helpful to survey the official immigration process as it occurred between the East German refugee and the Canadian

\footnotetext{
${ }^{87}$ RG26 Vol 127 File 3-33-13 Ritchie to Fortier March 25, 1953. "...the Communists, who are no fools, and would soon know that it is impossible to properly screen this group, might take advantage of this open channel to send their agents to Canada. This risk, you will appreciate, is a very serious one."

${ }^{88}$ Kelley and Trebilcock, p.339.

${ }^{89}$ RG76 Vol. 821, File 552-1-551 part 1. Robillard to Von Schmoller. April 71955.
} 
bureaucracy. The Stage B screening needs to be specifically emphasized, for its explicit purpose was to sift out those immigrants who would "be inimical to the democratic way of life and government as such is generally understood in Canada"-in other words, Communists. ${ }^{90}$

The involved process of Canadian acceptance required a great deal of time, paperwork, interviews, and patience. It included three sections: Stage A, Stage B, and Stage C, although in practice such an order was generally not followed. Before even being presented at the Canadian Mission, a potential immigrant had to have applied for a visa at least seven to eight weeks beforehand in order to have the given security checks accomplished. $^{91}$ The application form (Form 55) included a questionnaire that demanded basic biographical information, which was thereupon transferred to a Stage B (RCMP) officer who performed the necessary background checks. ${ }^{92}$ Upon completion of such 'research,' the candidate was called up to the immigration post where he or she was interviewed by the Stage B officer, who afterwards, verified the information obtained through the interview. If any serious doubts arose, he would find "in favour of Canada" and the applicant would fail Stage B. ${ }^{93}$ Due to a backlog of applicants, there was often a considerable delay to receive Stage B results; however, because the subsequent step,

\footnotetext{
${ }^{90}$ RG76 Vol 935 Binder \#10 "Instructions for the Guidance of Immigration and Visa Officers Vol. II" Section 7.01; Though there was certainly an element of keeping Nazi War Criminals out of Canada, both Whitaker and Margolian suggest that Cold War anxieties regarding Communists and Socialists took precedence.

${ }^{91}$ RG76 Vol 801 547-5-551 pt.1. G.R. Benoit (Chief Operations Division) to Inspector K.W.N. Hall, (Ottawa RCMP) March 1, 1952.

${ }_{92}$ Margolian suggests that in Germany, this form was filled out by an overseas sponsor. However, it appears that by 1953 , because restrictions had been lifted by 1953 , I would suggest that although Hundreiser did fill out paperwork, the Krolls applied with their own Form 55. Margolian, pp.101-2; RCMP officers who conducted Security B screenings were not to be referred to as such, for Canada was not to have the reputation of having police officers working abroad. RG26 Vol 127 File 3-33-13. Nicholson to Ritchie, April 4, 1953; RG76 Vol 801 547-5-551 pt.1. G.R. Benoit (Chief Operations Division) to Inspector K.W.N. Hall, (Ottawa RCMP) March 1, 1952.

${ }^{93}$ Margolian, p.104.
} 
Stage C-an interview with a visa officer-relied heavily upon the Stage B screening, such waits were necessary. ${ }^{94}$ After a successful Stage $C$, the process generally proceeded smoothly. ${ }^{95}$ It was only at this point that the applicant actually underwent Stage A-a medical exam which screened out those with chronic health problems or communicable disease. Following this last step, Stage A, the applicant was then moved towards visa and travel arrangements. ${ }^{96}$ Thus, arrangements all hinged upon a successful Stage B screening, a rather tricky and time consuming process.

A Stage B security clearance was mandatory to obtain a Canadian visa. Canadian Immigration required that all residents coming from behind the Iron Curtain meet a two year residency rule, in which they remained in the country (where the Canadian visa office to which they had applied was located) in order to allow the RCMP to complete a thorough security check and accrue information regarding their character, political background, and/or criminal history. Refugees from East Germany (but who were residents of West Germany) were considered an exception to the rule. ${ }^{97}$ According to the Director of Immigration they should be

excluded from the two year residence rule in view of the extremely hazardous circumstances in which they some times succeed to gain access to a country of which they are not a national. It is recognized that this would, to some extent, weaken the security screening in that regard but it would be difficult not to allow for some concession in respect of such bona fide refugees. ${ }^{98}$

\footnotetext{
${ }^{94}$ RG 76 Vol 935, Binder \#10. Instructions for the Guidance of Immigration and Visa Officers, Volume II. Section 7.37. Often times, the application had not been 'passed' by the scheduled interview/exam date, so further waiting ensued-much to the irritation of applicants. RG76 Vol 801 547-5-551 pt. 1 Chief, Karlsruhe to Chief Operations Division, Ottawa. February 2, 1955.

${ }^{95}$ RG76 Vol $801547-5-551$ pt. 1 Chief, Karlsruhe to Chief Operations Division, Ottawa. February 2, 1955. Changes were made to the process shortly thereafter, see RG76 Vol 801 547-5-551 pt.1 T.R. Burns to Chief Operations. June 23, 1955.

${ }_{96}$ Margolian, pp.104-5.

${ }^{97}$ It is important to note that those still residing in East Germany were under no circumstances to be presented to the Canadian Immigration team. RG76 Vol 801 547-5-551 pt.1 Acting Chief Admissions Director to Eastern District Superintendent, May 4, 1953.; RG76 Vol 800 547-1 pt.2 London (no names given) Mach 26, 1953.

${ }^{88}$ RG76 Vol 800 547-1 pt.2 Director to Deputy Minister, March 281952.
} 
However, Canadian Immigration records reveal that such a decision was an issue of contention between the RCMP, Department of Citizenship and Immigration, and the Department of External Affairs. ${ }^{99}$

The dispute regarding the security clearance of the German refugees is logical considering the departments' mandates. External Affairs' interests lay in promoting the image of a humanitarian Canada that was a major international player; furthermore, its officials were often on the 'ground' and therefore could see the plight of the refugees as well as the refugees' potential as 'good quality' immigrants. ${ }^{100}$ It is thus fitting that External Affairs endorsed the most liberal policy. In contrast, the Department of Immigration's concerns were domestic and revolved around Canadian public opinion and the immigrants' ability to integrate successfully. ${ }^{101}$ Apart from its long history of exclusionary practices, the Immigration Department was also relatively inexperienced, understaffed, and had jurisdictional concerns, evoking attempts to keep a tight hold on policy. ${ }^{102}$ Lastly, the RCMP was responsible for the nation's security. Therefore, it was understandably in the agency's best interest to take a cautious approach to the East German refugees; it performed the latter with its insistence on following strict security measures. ${ }^{103}$

\footnotetext{
${ }^{99}$ For example, see RG26 Vol 127 File 3-33-13 correspondence between Laval and L.H. Nicholson (RCMP Commissioner), March 10, 1953 and March 11, 1953.

${ }^{100}$ Dirks, pp. 125, 139, 149.

${ }^{101}$ Dirks, p.148.

${ }^{102}$ Such attempts at maintaining control were in part responsible for much inter-departmental squabbling in the postwar years. Dirks, p. 149 .

${ }^{103}$ The 'two year rule' was the source of considerable debate within the Canadian Government. There was confusion as to whose instructions the RCMP was following, and disputes concerning the existing format's rationale. In the eyes of External Affairs, the RCMP were either misinformed and thought that the two year residency rule applied to German refugees, or, they were simply too stringent in their selection, thinking it too great a risk. ${ }^{103}$ RCMP agents often ignored the policy exception and by consequence, Canada would lose "by far the best crop of such [immigration] candidates seen in a long time." 103 The Department of Immigration generally supported the RCMP's extreme caution, and was also reluctant to change procedure
} 
The first meeting with the Canadians was momentous for both Helma and her husband, though the experience began before the actual interview. They were both "excited, tense, you name it" in the days leading up to the meeting, knowing fully well what was at stake. ${ }^{104}$ In a letter to her parents-in-law, Helma recounts that while there, she sat under a Canadian map when an employee came to look at it with another individual. Helma moved to make room for them, for which the official thanked her. She responded in kind with "you're welcome." It was her "first word to a Canadian," and she went bright red. ${ }^{105}$ She laughs at the memory, but in a letter to her husband's parents, recognizes that this is an "important happening," though one which her "children in later years...won't understand." ${ }^{\prime 06}$ This comment is significant for it indicates that at the time, Helma recognized that the meeting at the Canadian Consulate was the first step towards her family's new life; it was a story that she could recount in later years, a meaningful moment in the family's history. ${ }^{107}$

Within the interview process itself, Helma's immediate role was minimal. The Canadian authorities were primarily interested in Reinhard; not only was he the partner with direct ties to the Communist Government, but he was also the male breadwinner who presumably would be the primary wage earner in Canada. Thus, he alone was interviewed in Berlin. Sociologist Monica Boyd has demonstrated that married immigrant

\footnotetext{
or policy. ${ }^{103}$ However, the often lengthy delay provoked complaints from Canadian officials and immigrants alike, and efforts were made to 'speed things up.' In a meeting between the two departments, the RCMP, and the Privy Council, a compromise was reached: officers would attempt to be more lenient in their rejections of refugees (perhaps through more experience); but they would also take refugees who had been in West Germany for a longer period, even if not the much disputed two years. See correspondence dated between February 2, 1953 to February 15, 1953 in RG26 Vol 127 File 3-33-13; RG76 Vol 800 547-1 pt.2; RG76 Vol 801 547-5-551 pt.1.

${ }^{104}$ Helma Kroll to Richard and Elfriede Kroll. September 28, 1953. Book 1, p.23.

${ }^{105}$ Interview with Helma Kroll, June 20, 2005. p.5.

${ }^{106}$ Helma Kroll to Richard and Elfriede Kroll. September 28, 1953. Book 1, p.24.

${ }^{107}$ See Alistair Thomson's discussion of the role of immigration stories within a family. Thomson, "Moving Stories: Oral History and Migration Studies," Oral History (Spring 1999) 31-2, 35.
} 
women were most often judged as dependent upon their husbands, and were thus disregarded by immigration officials as potential sources of labour. ${ }^{108}$ As Helma's story ironically reveals, even though she would become a crucial wage-earner in the family economy she was dismissed from the interview process. Because Helma had only a supporting role during the interview process, her value as a 'witness' hinges upon the testimony she can provide about the preparation and the aftermath, rather than the line of questioning used by the Canadian officials. She was an equal and supportive partner in enduring the long struggle to be accepted. In a telling passage to his parents, Reinhard says of himself and Helma that "with us it goes alternately, always one has to encourage the other." 109 There is a deep sense of cooperation and interdependence within the marriage, suggesting that Reinhard needed Helma for moral support, if not for practical matters. Helma later refers to Reinhard's need for her encouragement, and also consistently uses the first person plural when describing relevant events at the Consulate-indicating that she was implicated in the process, even if indirectly. ${ }^{110}$ In the hallways of the consulate, both Helma and Reinhard were surprised by the numbers of other Germans who wanted to go to Canada, and listened to those around them discuss their experiences with the Canadian authorities. ${ }^{11}$ Helma waited with Reinhard in the various lines, and perhaps helped him prepare for the interview with the information that she overheard; when Reinhard went into the interview room, Helma "waited in nervousness," outside in the corridor. Reinhard returned with a stamp on his application which neither of them understood; when he translated it as "deferred" they "were both

\footnotetext{
${ }^{108}$ Monica Boyd, "The Status of Immigrant Women in Canada," Canadian Review of Sociology and Anthropology 12 (1975): 407.

${ }^{109}$ Reinhard Kroll to Richard and Elfriede Kroll. [September] 20, 1953. Book 1, p.23.

${ }^{110}$ Helma Kroll to Eleonore Scholz. July 1, 1954. Book 1, p.50.

${ }^{111}$ Helma Kroll to Richard and Elfriede Kroll. September 28, 1953. Book 1, p.23.
} 
very upset," and Helma "started to cry." "112 However, Reinhard was soon thereafter called in for a second interview, which was successful and started the visa application.

Thereafter, Helma joined Reinhard in active involvement with the screening and preparation process: $\mathrm{x}$-rays, passports, medical exams and the like had to be completed quickly. While Reinhard seems to have played a greater role in the bureaucratic channels - for example, he "went to the welfare office trying to get [them] the $\mathrm{x}$-rays without charge"- -Helma 'took charge' of the realm of the household; for example, she seems to have taken on the responsibility for packing the family's goods, as she personally expresses great anxiety about getting them together (for they were in various locations) before their departure. ${ }^{113}$

The Krolls hoped to be out of Germany at the end of October 1953. However, for unspecified reasons - perhaps a deferred Stage B screening, paperwork delays, or an absence of room on the boat - they did not make the last ship. Instead, they were flown to a refugee camp in Wentorf, where unbeknownst to them, they would reside for the next year. It should be noted that the bureaucratic details of the immigration process are not conveyed by Helma, either in letters or oral testimony, because she was not directly involved. By contrast, her account of the camps, both through letters and oral testimony is vivid. This is logical given the length of the Krolls' stay, in combination with some very challenging conditions. ${ }^{114}$

The Krolls flew to Hamburg on October 19, 1953. Their departure, journey, and arrival at the new refugee camp suggest that as refugees, their mindset was imbued with a

\footnotetext{
${ }^{112}$ Helma Kroll to Richard and Elfriede Kroll. September 28, 1953. Book 1, p.24.

${ }^{113}$ Helma Kroll to Richard and Elfriede Kroll. September 28, 1953. Book 1, p.24.

${ }^{114}$ Barber states that we are more likely to remember emotionally-charged periods of conflict, hardship, or contentment. Marilyn Barber. "Hearing Women's Voices: Female Migration to Canada in the Early

Twentieth Century," Oral History, 3, no.1 (Spring 2005): 70.
} 
sense of being second-class citizens. It is interesting to note that this theme does not arise in Berlin until they leave. In preparation for departure, the Krolls were subject to a series of medical exams, which Helma describes as "soul destroying." They included a thorough-_everywhere, and I say everywhere"-inspection for lice three times: twice before leaving Berlin, and once upon their arrival at Wentorf. Though Helma recognizes that "it is right that they are doing it" she states that "it did not help our mental condition very much." 115 The vulnerability produced by such checks was very difficult for people with no permanent roots except to each other. ${ }^{116}$ It certainly would have been a step away from the dignity with which Helma and her husband had once been accustomed to being treated. The flight to the camp provides an excellent foil to both the medical exams and the conditions which the Krolls were to encounter; that it is a central theme in both Reinhard's and Helma's writing is revealing, for they both stress how they "felt like ordinary 'persons,' and were very well treated." 117 The fact that Reinhard uses quotations around the word 'persons,' indicates that the treatment he went through as a refugee had a dehumanizing effect. Similarly, Helma refers to the flight as "one and a half hour[s] between heaven and earth in a fairytale land" where they "were treated like paying passengers." Here, she also implies that as a refugee, she is accorded different treatment. Her last experience of "civilization" before reaching the camp was "in the form of a wonderful washroom;" recognizing that this might be humorous to her parents-in-law,

\footnotetext{
${ }^{115}$ Helma Kroll to Richard and Elfriede Kroll. October 20, 1953. Book 1, p.25.

${ }^{116}$ This has been confirmed in accounts of previous DPs who underwent such medical examinations and processes, such as lice checks and DDT spraying. Women in particular objected to the indignity of being sprayed with DDT under their skirts. However, such medical measures were overwhelmingly successful. Mark Wyman, DP Europe's Displaced Persons, 1945-51 (Toronto: Associated University Press, 1989), p.50.

${ }^{17}$ Reinhard Kroll to Richard and Elfriede Kroll. October 19, 1953. Book 1, p.25.
} 
Helma begs them not to laugh, but these new conditions-including a new appreciation for what used to be the 'ordinary'-have become her reality. ${ }^{118}$

In the letters to their parents, both Helma's and Reinhard's tones seem to be relatively optimistic; however, conditions at the camp were very challenging and took a toll on their morale. Their letters reflect this, as does Helma's oral testimony. The Krolls were five of ten thousand refugees in Weldorf, at a camp referred to as "a small town living very tightly together." It was a former army barracks, composed of twenty, threestory houses, each of which housed 500 refugees. The camp had three large kitchens (including one for special diets and one to make baby food) two drop-in centres, three kindergartens, one hospital, and one quarantine centre, and, in Helma's estimation, employed about 300 staff, and more than 600 volunteers. ${ }^{119}$ The camp met individuals' basic physical needs, providing food (in abundance), shelter, warmth, healthcare, and even education for young children. However, it did not provide an environment conducive to maintaining mental health and emotional well-being.

Such crowded living conditions violated the notion of a private living space, providing some solace from the outside world. Though the Krolls had an enclosed sphere of sorts in which they ate, slept, and socialized, it was cramped and in such close proximity to others that the external world invaded the sanctity of the domestic realm. The Krolls had shared space with others before, but at the refugee camp they encountered a new extreme: space was tight, and their period of residence was indefinite. The overcrowding of the camps is a major theme in both the letters and Helma's oral testimony. In a study of Japanese intern-camp survivors during World War Two, Mona

\footnotetext{
${ }^{118}$ Helma Kroll to Richard and Elfriede Kroll. October 20, 1953. Book 1, p. 25.

${ }^{119}$ Helma Kroll to Eleonore Scholz. November 29, 1953. Book 1, p.30.
} 
Oikawa demonstrates that memories are greatly influenced by "the spatial details." Space makes social relations visible, and likewise, produces new ones, to which inhabitants must adhere. ${ }^{120}$ Particularly for women, restricted space was linked to the family and motherhood. The illness of children and the pressures of being with family in such confinement are remembered as particular hardships. ${ }^{121}$ As a larger family, the Krolls were 'lucky' to share a room with 'only' one other family: a grandmother, mother and two "terribly noisy" children. ${ }^{122}$ Though attempts at privacy were made with a "wall' of blankets, the division could not drown out the noise or the smell of 'such close living quarters. ${ }^{123}$ The tight living space created problems in its own right, and amplified those which already existed. Overcrowding produced what might be called both 'physical' and 'emotional' stress. Yet, these imposed categories do not fit so easily when one probes deeper; although physical proximity produced 'concrete' challenges, corporeal trials became internal as well.

For Helma, the two most difficult things about the refugee camp were "the lack of privacy" and the sense of 'uprootedness.' I would argue that the former amplified the latter to a large degree. Even within one's own space, privacy was unattainable, for in reality little was one's own. Personal peace was hard to attain given the lack of solitude denoted by cohabitation. The Krolls' residence was filled with the constant noise which the three children produced, causing the home to resemble "Central Station," especially on rainy days. ${ }^{124}$ Moreover, the lack of personal space would conceivably have put stress

\footnotetext{
${ }^{120}$ Mona Oikawa. "Cartographies of Violence: Women, Memory, and the Subject(s) of the 'Internment,", in Race, Space and the Law: Unmapping a White Settler Society. Edited by, Sherene H. Razack (Toronto: Between the Lines, 2002), pp.74-6.

${ }_{121}$ Oikawa, Race, Space and the Law: Unmapping a White Settler Society, p.94.

${ }^{122}$ Helma Kroll to Richard and Elfriede Kroll. October 20, 1953. Book 1, p.25.

${ }^{123}$ Helma Kroll, memoir, March 8, 2001. Book 1, p.28.

${ }^{124}$ Helma Kroll to Elfriede Kroll. February 2, 1954. Book 1, p.35.
} 
on personal relationships. Even at night - a brief period which typically offers parents a few hours reprieve- the Krolls were within eyesight of their children. A common practical concern related to sex: Helma laughs as she recounts Gerd's unofficial 'sex education,' and even Reinhard refers to such activity in the context of his neighbours' 'necking., ${ }^{125}$ Even though Helma and Reinhard were ignorant of their own voyeur at the time, one must still wonder what the ramifications of such immediacy and lack of 'quiet time' had on a marriage. From such a personal experience as sex to emotional bonding, the couple was never free from the prying eyes of neighbours or children.

Even in such a place of transition, "life [still] happened." 126 People had affairs and arguments just as they would have on the 'outside,' the difference being that in such tight quarters, one was never isolated from the event in question. Not only did the Krolls lack privacy within their immediate family, but they were also within their neighbours' line of hearing. For Reinhard, this was illustrated by his regular irritation at their neighbours' loud radio. Moreover, intimate human dramas invaded others' personal space, providing both entertainment and disruption. For example, on Christmas morning the Krolls' new neighbours—a family composed of a recent common-law couple—were interrupted by the man's former fiancé, who called herself his wife. Understandably, drama ensued and because of their physical proximity, the Krolls spent the day as an unwitting audience to their neighbours' unscripted "family entertainment." 127 Though Helma recalls this event with some amusement, at the time, this was conceivably just one more reminder that their home was not their own. Within the letters and testimony, the

\footnotetext{
${ }^{125}$ Interview with Helma Kroll, June 20, 2005. p.9.

${ }^{126}$ Interview with Beate Myhill, June 20, 2005. p. 10.

${ }^{127}$ Reinhard and Helma Kroll to Eleonore Scholz and Richard and Elfriede Kroll. December 27, 1953. Book 1, p.33.
} 
absence of social activity with one's neighbours is telling; perhaps this imposed intimacy beget a conscious effort to keep distance from others as much as possible, apart from the occasional gossip in the laundry room.

Aspects of everyday life were under a microscope in such a concentrated microcosm, and the Krolls yearned for distance. Though the Krolls recount some of these events with humour, their letters express the emotional stress and frustration such a lack of personal space caused them. The crowded conditions produced poor morale, particularly in an environment where all the residents were in a state of limbo. A Canadian official noted that

The conditions in Fluechtlingslaegern or camps is worse than it was during the hectic days of DP camps. Even he, who is in large barracks, succeeds in separating a few square yards with old towels in pieces of card board, lives continuously with his family in a noisy atmosphere of collectivity which gives no pity.... ${ }^{128}$

Throughout their letters, one has the sense that Helma and Reinhard are just trying cope.

The overcrowding could "shatter the strongest person" and it took memories of the past, and hope for the future, to sustain oneself. ${ }^{129}$ As Reinhard wrote,

Say 'Yes' to the past, and 'Yes' to the future, because if we wouldn't have them, we couldn't cope with the present. When we have a bad time and think it is too much, only the thought and trust in our future keeps us going. ${ }^{130}$

Though the letters provided a sense of connectedness with both the Krolls' family and their past, in hindsight, Helma says the one thing which she missed the most was their future. ${ }^{131}$ As one East German refugee recalls, You have nothing-you are nothing. This whole idea of loss-loss of home, of

\footnotetext{
${ }^{128}$ RG26 Vol 127 File 3-33-13J.A. Sharrer in Karslruhe, December 4, 1950. Sharrer is an employment officer with the National Employment Service; presumably, he works for the Department of Labour. ${ }^{129}$ Helma Kroll to Eleonore Scholz. November 29, 1953. Book 1, p.30.

${ }^{130}$ Reinhard Kroll to Eleonore Scholz and Richard and Elfriede Kroll. December 17, 1953. Book 1, p.31.

${ }^{131}$ Interview with Helma Kroll, June 20, 2005. p.12.
} 
livelihood-this unsettled state of being, of being displaced, creates a deep sense of insecurity in people. At least it did in me. Insecurity about the future. You never know what is going to happen, even if things got better. You don't know if this is going to last. ${ }^{132}$

There were simply too many people at the camp, each in a similar place of uncertainty.

One aspect of the insecurity occurred at an emotional level but was linked with physical safety as well; some had still not made the adjustment to 'being safe,' and lived in fear about the future and the past. This was particularly true of children, for whom the threat of the ominous 'Russian' was still real and haunted them in their dreams, even in the Western Zone. ${ }^{133}$ Beate recounts a regular nightmare:

I was on the bottom bunk. I could see out that glass window in the door, to the light bulb in the hallway, and I would wake up at night, terrified that the Russian soldiers were coming to get us- that it was a flashlight shining in to get us. ${ }^{134}$

Her alarm echoes another child's testimony:

I had a dream of being in an empty room on the second floor, and the Russian showed up outside the window, getting ready to come and get me. He didn't have a face. It was only this figure, this threatening body in a uniform. . . .I had another nightmare where the Russian was sitting by the side of the road in uniform, twirling a knife on his index finger, looking at me as I was coming with my bike. $^{135}$

One can only imagine the emotional climate which pervaded the camp. With so many people enclosed in such a small area, with varying motives and paths, but all uncertain of what lay ahead, life was difficult. In many respects, the camp seems to be a quasi-purgatory where individuals were suspended between the past and the future, in a reality which was far removed from many people's previous standard of living. ${ }^{136}$ Refugees did the necessary footwork, and then had to wait upon the bureaucracy before

\footnotetext{
${ }^{132}$ Marika in Ursula Hegi, Tearing the Silence (New York: Simon and Schuster, 1996), p.201.

${ }^{133}$ Also see Marika in Hegi, p.200. Note, the italics are directly transcribed from Hegi's text.

${ }^{134}$ Interview with Beate Myhill, June 8, 2005, p.15.

${ }^{135}$ Marika in Hegi, p.200.

${ }^{136}$ Danys, p.41.
} 
action was taken; the future was not directly in their hands, but rather, largely in the hands of others. Furthermore, refugees were not just held hostage by circumstances but by the administrative regulations of the camp as well. Due to the sheer volume of people and limited space, rules were essential to establish and maintain order: what to eat, where to live, what to do, etc; however, in a rather ironic twist for those fleeing the Communist State, such regimentation challenged the degree of real 'liberty' that refugees felt they 'enjoyed.' "Rules and regulations were made very clear" to the Krolls upon their arrival; restrictions governed details as 'minute' as a child's time on the slide. ${ }^{137}$ According to Beate:

There was a parade square in the middle, which of course was just a piece of muddy grass at this time, and for all of these children - there were five or six thousand - there was one metal slide. Each apartment house had a certain hour of the day where the children from that building could go and slide down the slide, so the children would line up in this big, long line.... That was what children had to do outside of school hours. ${ }^{138}$

This passage also illustrates that although the camp had various infrastructures to provide for tenants' physical well-being, it was incomplete. Idleness was harmful to both the physical and mental well-being of the refugee; and although the camp provided such activities as a slide, and the cinema, camp life was meant to be temporary, and its fabric reflected this. ${ }^{139}$ Refugees' mental morale was also tried by their lack of movement. People were unemployed, which for individuals like Reinhard-accustomed to regular

\footnotetext{
${ }^{137}$ Helma Kroll to Richard and Elfriede Kroll. October 20, 1953. Book 1, p.25.

${ }^{138}$ Interview with Beate Myhill, June 20, 2005. p.11.

${ }^{139}$ This is in specific reference to postwar DP's. E.H. Wheatman, UNRRA field Supervisor, North Rhine region report, undated 1946, UNRRA Archives, Germany Mission, British Zone (Lemgo), Central Registry, Repatriation. As cited by Wyman, p.74; Richard Lehm. "Settling The East Zone Refugee The Task Of A West German Reception Camp," The Times, Thursday, Aug 20, 1953; pg. 7; Issue 52705; col F. Previous DP camps organized camp newspapers, sports teams, dances and the like (Wyman, p.118); this is not mentioned in any accounts of later refugee camps.
} 
and challenging work - would have taken a considerable toll on their personal esteem. ${ }^{140}$ This sense of boredom, combined with the lack of control one had over the 'big things' is exemplified by the amount of energy which some put into others' personal affairs. ${ }^{141}$ Perhaps in an effort to attain a degree of personal empowerment, or to simply occupy themselves, some refugees reported on others' 'breaking of the rules.' Beate recounts an incident in which she and her brothers were reported for taking a suspected Red Cross blanket outside. Though the blanket was actually the Krolls' and not one assigned by the Camp, the onus was on to Reinhard to prove so. Though this is a minor incident, it is disturbingly resonant with the life which the refugees had left behind in which informers were an expected presence. ${ }^{142}$

Physically and emotionally, the Krolls' lack of material goods was also difficult. Like other refugees, the Krolls had left the East with few personal belongings, namely the clothing on their back and whatever fit into one small bag. Although they had sent some items over previously, these were limited-the majority of their worldly goods had remained behind. ${ }^{143}$ The Kroll's "financial situation [was] tight;" besides occasional loans or gifts from family and friends, their primary source of funding came from Reinhard's unemployment insurance, to which he was entitled as a bona fide political refugee in the West. ${ }^{144}$ The camp met their most basic physical needs, but it did not provide the personal property necessary to obtain an individual's sense of dignity nor the feeling of

\footnotetext{
${ }^{140}$ Wyman, pp.106, 113.

${ }^{141}$ Interview with Beate Myhill, June 20, 2005. p.11; in the DP camps, there was also a widespread occurrence of homemade stilleries for alcohol; it is not clear whether this occurred in later refugee camps. Alcohol use was widespread, another way to 'escape.' Wyman, pp.108-9.

${ }^{142}$ I refer here to both the GDR's Volkspolizei and prior to that, the Third Reich's Gestapo.

143 They were given to Ema, the Krolls' foster daughter.

${ }^{144}$ Helma Kroll to Eleonore Scholz. November 29, 1953. Book 1, p.30; It is interesting to note that in her interview, Helma accentuates that " $\mathrm{He}$ (Reinhard) got unemployment." Interview with Helma Kroll, June 20, 2005. p. 10 .
} 
'home.' The Krolls had little by way of household merchandise, and Helma's letters were forthright in expressing need for certain items: a wash bowl, a piece of window glass (to function as a mirror), and other such practical goods. In this respect, the Krolls' letters also fulfilled a material need; they not only provided an emotional connection, but they were a tool with which to garner material goods. ${ }^{145}$ Helma writes to her parents-in-law to "please forgive our begging, but at the moment we are in a position where we can't be shy." ${ }^{146}$ Necessity removes any pretense of pride for those close to her, as she recognizes. Friends and family were very generous in their provisions, and sent new goods amongst used, which Helma used to imbue their small space with a sense of 'home.' However, when visitors witnessed first-hand the conditions in which the Krolls lived, a sense of shame is revealed. When a former colleague came to visit, Helma recalls "We were embarrassed....how [the children] acted" but also by his "full experience, the smell in the room, the arguing neighbours, children crying" - all typical features of their new environment. ${ }^{147}$ Interactions with the 'outside' had a similar effect on the Krolls. When Helma and Reinhard went shopping in the nearby town, their sense of identity was threatened by their relative poverty. Helma recalls that

After the first three stores we felt, we were being treated like second-class citizens, and had enough of it. We looked at each other, yes we looked like refugees $-I$ with a scarf as [a] headdress - it just was not right. ${ }^{148}$

For women in particular, clothing and appearance are often intimately connected to one's sense of self and personal worth, and depict one's social class and status. ${ }^{149}$ For Helma,

\footnotetext{
${ }^{145}$ Gerber, David A. "The Immigrant Letter between Positivism and Populism: The Uses of Immigrant Personal Correspondence in Twentieth-Century American Scholarship," The Journal of American Ethnic History 16, no.4 (Summer 1997): 3.

${ }^{146}$ Helma Kroll to Richard and Elfriede Kroll. October 20, 1953. Book 1, p.26.

${ }^{147}$ Helma Kroll to Elfriede Kroll. October 28, 1953. Book 1, p.28.

${ }^{148}$ Reinhard and Helma Kroll to Eleonore Scholz and Richard and Elfriede Kroll. December 27, 1953. Book 1, p.32.
} 
the disparity between her physical appearance and that of those around her seems to have illustrated such loss. Although the Krolls had largely become accustomed to their circumstances, they were the most conscious of their reality when in contact with those from the 'outside,' likely because at the camp they were surrounded by those whose appearance reflected their own, and thus they ordinarily gave it little thought. However, when confronted with such a reality on the 'outside,' the Krolls took an active step in response to their 'realization.' They asserted that this was not their station in life, and with money left to them by a relative, in addition to a refugee bonus, they went shopping. They 'justifiably' purchased a hat and dress for Helma and a briefcase for Reinhard; the latter, according to Helma, had the effect of swiftly increasing Reinhard's selfconfidence. This passage confirms both the connection between material possessions and self-identity; it also provides insight into the Krolls' sense of personal dignity.

A strong current of personal agency runs throughout the Krolls' narrative. The active role they took to boost their self-confidence through the purchase of clothing is only a small display of a determined effort to improve their given circumstances while at the camp. The notion of agency is particularly relevant to the Krolls' experience, and is also tied to their unflagging optimistic spirit. In spite of difficult conditions, the Krolls persevered. They made an effort to both appreciate what they did have and tried to ameliorate their conditions - both physical and emotional — as best they could.

Though the camp was a temporary residence, the Krolls created an important sense of 'home' in their limited space. In part, this was due to the mere appreciation of being together as one family unit, which Helma refers to as 'a beautiful togetherness.

\footnotetext{
${ }^{149}$ For example, see Eva Hoffman, Lost in Translation_(New York: Penguin, 1989), pp. 103, 109.

${ }^{150}$ Interview with Helma Kroll, June 8, 2005, p.15.
} 
Beate testifies "I had my family, I was safe;" ${ }^{151}$ from the perspective of a five year old, though crowdedness may have been unpleasant and provoked stress in her parents, her most important needs were met. For Helma though, the conditions were obviously challenging. Nonetheless, Helma found that the situation at the camp was better given that the family could now live together again (they were no longer segregated according to gender). Despite the challenges of a cramped space (which resulted in Gerd's inadvertent 'sex education), 'togetherness' was valued. ${ }^{152}$ Even when a forester friend in the West offered to take the children, the Krolls refused. Helma wrote: "we don't have the courage and believe a separation would not be too good for the children." Despite its inconveniences, Helma's favourite aspect of the camp was "the family life": walks, picking flowers - activities which were not special except that they were done in a safe place with the entire family.

Even if the future was uncertain, the family unit was a given. Moreover, the Krolls "made a home out of this little place" through their physical environment. ${ }^{153}$ Though Helma initially uses the pronoun 'we' to describe this process of home décor, it seems probable that Helma was at the centre of such activity, especially since it is typical for women to use the first person plural, negate their own role, and give credit to others, within their oral testimony. ${ }^{154}$ On occasion, Helma does use the first person singular:

I hung the curtains I had made out of the material we had bought from the premium in Schweinitz... we put the antlers, and two more pictures grandparents Kroll sent us in one of their many parcels on the wall... [making the room] look so much more like home. ${ }^{155}$

\footnotetext{
${ }^{151}$ Interview with Beate Myhill June 8, 2005, p. 15.

${ }^{152}$ Helma Kroll to Richard and Elfriede Kroll. October 20, 1953. Book 1, p.25.

${ }^{153}$ Interview with Helma Kroll, June 20, 2005. p.9.

${ }^{154}$ Isabelle Bertaux-Wiame as cited by Thompson,, p. 155; Gwen Etter-Lewis as cited by Sangster, Rethinking Canada: The Promise of Women's History, p.223.

${ }^{155}$ Reinhard and Helma Kroll to Eleonore Scholz and Richard and Elfriede Kroll. December 27, 1953. Book 1, p.32.
} 
In her recollection of the gifts sent, small tokens included, Helma surmises that it is "those little things which make a home." ${ }^{" 156}$ Evidently, despite a lack of furniture, and lack of room, the Krolls came to find some roots, even if shallow, in this small space. Inexpensive gifts with connections to the family, tokens of the previous life, and small possessions which were at least their own, grounded the Krolls to their physical location, their past, and even their hope for the future. Likely, such mementos-even those of little value - strengthened the Krolls' personal identity in a time where everything else around them was in flux. Mail parcels which included art work, practical goods, and even food, tied the Krolls to their sense of self and personal history. It is ironic that food-the one item that was truly abundant at the camp—elicited such a noteworthy response. Helma and Reinhard make numerous references to it. Though one might conclude that such mention was simply to please their parents and enforce the notion that the parents were (and could) do something positive to help their adult children, I would suggest that such gratitude was not merely to placate, but that it also demonstrated a genuine appreciation for an item which brought the Krolls joy. Historians such as Epp, Langfield and Maclean have demonstrated that food is a powerful tool which has the ability to tie one to a temporal space and time. ${ }^{157}$ Particularly within migration narratives, food gains prominence, often providing a sharp contrast with preceding periods of austerity. ${ }^{158}$ The Krolls were very well fed at the refugee camp, but they were in a strange environment apart from their friends and family. For them, Epp's assertion that food "functions as a

\footnotetext{
${ }^{156}$ Interview with Helma Kroll, June 20, 2005. p. 10.

${ }^{157}$ Langfield and Maclean, Speaking to Immigrants; Epp, Sisters or Strangers.

${ }^{158}$ Epp, Sisters or Strangers: Immigrant, Ethnic and Racialized Women in Canadian History, p.328.
} 
means of recall" holds true. ${ }^{159}$ As an object of both 'practicality' and 'pleasure,' it provided a great deal of emotional comfort. Mailed cake and coffee "tasted very good like home," and likely reconnected them to both family and memories of a more secure and emotionally content period, perhaps transcending the uncertainty which surrounded them. ${ }^{160}$ Food and other physical objects sent by the Krolls' family were imbued with familiarity and meaning; these things once again made home a 'safe' place, and to an extent, forged a peaceful respite from camp life — or the 'outside.'

The Krolls also continued to honour holidays, providing their children with both a highlight in the present and a sense of continuity with the past. As Mark Wyman has documented in his study of postwar Europe, the recognition of holidays provided displaced people with a "link to tradition" and therefore their own history. ${ }^{161}$ The children's birthdays were celebrated with gifts, and although Helma and Reinhard dreaded Christmas at the camp — and counted on the "many wonderful memories of other years...to get [them] through this one" - they were pleasantly surprised. ${ }^{162}$ In a tradition which stemmed back to the DP camps, the children received care packages from overseas American donations in a camp-orchestrated event. ${ }^{163}$ In light of this, and "because of all the wonderful help [they got] from relatives and friends" Helma could write that "we are not that poor;" they were able to go Christmas shopping with money donated by the government and family, and truly enjoy their Christmas. ${ }^{164}$ They were overwhelmed by those who cared: visits by friends, packages and letters from those near and far-the family "got far more gifts than any time in Schweinitz." Their children's enthusiasm was

\footnotetext{
${ }^{159}$ Epp, Sisters or Strangers: Immigrant, Ethnic and Racialized Women in Canadian History, p.316..

${ }^{160}$ Helma Kroll to Eleonore Scholz and her mother, Helene Schmitt March 3, 1954. Book 1, p.38.

${ }^{161}$ Wyman, p.112.

${ }^{162}$ Helma Kroll to Eleonore Scholz and Richard and Elfriede Kroll. December 17, 1953. Book 1, p.30.

${ }^{163}$ Wyman, p. 112 .

${ }^{164}$ Helma Kroll to Eleonore Scholz and Richard and Elfriede Kroll. December 17, 1953. Book 1, p.31.
} 
contagious, and amidst all the bustle of the holidays, and the many reminders that they were not so far away in their families' hearts, Helma and Reinhard "did not have time for a sad moment.",165

A bright camp highlight for both Helma and Beate occurred in the spring when Beate won a prize which included a free shopping trip. In some respects, this event seems like a miniature fairy tale in the memory of both women, whereas in the letters, it comes across as slightly more mundane. A nation-wide contest had been held between a publishing house and travel agency, and "now they were looking for a nice little refugee to pick the winner." Beate, the kindergarten's "teacher's pet" was chosen by an employee. ${ }^{166}$ Though the original intention had been for only one child, 'the proud parents" approval depended upon the inclusion of Hartmuth as well. The company agreed; thus, the well-dressed children were picked up and drew more than one hundred prizes, while their mother anxiously worried about their behaviour. ${ }^{167}$ The next day, Helma accompanied the children on their shopping trip, "to give some guidance" as to what was needed. They started out at a very expensive children's boutique until Helma told them that this was not their "style and as refugees [they] needed some more practical stuff." Evidently, Helma intended to use this prize to a practical good, for the family could not afford to let such an opportunity fall upon frivolous purchases. The company's agenda differed from Helma's, for the children were to be used as subjects for a magazine article; nevertheless, it acquiesced to her concerns. The children were asked to choose and they picked out a full outfit each; but, when Hartmuth and Helma disagreed on shoes-

\footnotetext{
${ }^{165}$ Helma and Reinhard Kroll to Eleonore Scholz and Richard and Elfriede Kroll. December 27, 1953. Book 1.p.33.

${ }^{166}$ Interview with Helma Kroll, June 20, 2005. p.9.

${ }^{167}$ Helma and Reinhard Kroll to Eleonore Scholz and Richard and Elfriede Kroll. April 17, 1954. Book 1, p.42.
} 
Hartmuth insisted on white versus a practical brown - the man accompanying them 'quietly' bought both. ${ }^{168}$ Pictures were taken of the children at the zoo, and their pictures and the article appeared one month later in The Constance. ${ }^{169}$ For the children, this meant much individual attention and a voice in clothes shopping - certainly a first time experience within the refugee camp, at the very least. ${ }^{170}$ For Helma and Reinhard, it was an unexpected windfall in which their children received practical merchandise, and they were given the opportunity to be proud parents of well dressed children before the West German public.

Throughout the Krolls' twelve months in West Germany, they received visits from numerous friends, family members, and former colleagues. Although guests could create feelings of self-consciousness, they brought useful and welcomed goods. More importantly, given that the present was a difficult place in which to exist, they offered a break from the 'now' and connected the Krolls' to their past. Nevertheless, when conditions at the camp became too taxing on their sense of well-being and when emotional escape would not suffice, the Krolls were able to leave physically as well. Visits to friends in the West, work or volunteer leaves, and quick 'outings' to the local town were sometimes necessary breaks, often taken individually because of the children. They offered a reprieve from the stifling atmosphere of the camp, when even a recreated home (of sorts) could not alleviate the stressful existence in the camp bubble.

\footnotetext{
${ }^{168}$ Helma and Reinhard Kroll to Eleonore Scholz and Richard and Elfriede Kroll. April 17, 1954. Book 1, p. 42. Note that Helma seems to be the speaker, which suggests that she was the author of this letter, not just the secretary.

${ }_{169}$ Beate states that this "was the German version of Life magazine." Interview with Helma Kroll, June 20, 2005. p.11.

${ }^{170}$ Gerd, who felt left out, was rewarded by a shopping trip of his own, though this one funded by his parents. Interview with Helma Kroll, June 20, 2006, p.11.
} 
The Krolls' immigration was delayed until September 1954; this postponement occurred in increments and thus the Krolls' hopes fluctuated. Throughout the winter, the shipping of Canadian immigrants ceased, and the initial couple of months in the New Year were reserved for 'family reunions. ${ }^{, 171}$ After these official setbacks, the Krolls faced more incidental ones. They wrote to immigration officials to have their papers sent from Berlin to Hamburg (near Wentorf), but instead, the papers were delivered to Hannover. By mid-March the correct papers were in Hamburg, and Reinhard had the first interview with the Canadians there. It is unclear in the letters as to how this interview relates to previous ones in Berlin — perhaps this interview was with a visa officer, or perhaps Reinhard's previous Stage B security check had been deferred. What is significant is that the Canadian authorities could not "believe that Reinhard, as government employee for seven years, was not in the communist party." Helma recognized that this would not be a problem to prove, given that they "ha[d] enough people with 'contacts' who [could] give references..." but nonetheless, once this question was resolved, it entailed another four weeks wait. To this, Helma was resigned, for they had already "learned the waiting game." 172

In midst of such delays, everyday life had to find some degree of normality. For all of the camp's weaknesses, it offered the children routine. Hartmouth and Beate were enrolled in a Kindergarten, while Gerd went to a public school outside the camp's borders. School provided the children with an additional sense of stability, as well as activity to keep them busy, with such enterprises as a school play. For their parents, it offered some relatively quiet time, but also gave the Krolls the opportunity to "work on

\footnotetext{
${ }^{171}$ Helma Kroll to Eleonore Scholz. November 29, 1953, Book 1, p.30.

${ }^{172}$ Helma Kroll to Eleonore Scholz. March 12, 1954. Book 1, p.39.
} 
[their] future" and pursue other endeavours. ${ }^{173}$ Helma was an active agent in changing the family's circumstances through her work outside the home. In what was a conscious effort to upgrade her family's accommodations, she took on a volunteer position with the Red Cross, who helped run the camp. The amicable relationships Helma developed with officials through such a position offers an explanation as to why the Krolls might not have felt like "just another number," which was typical of so many people grouped together in a camp setting. ${ }^{174}$ Helma's position also afforded the Krolls "another room, a little bit bigger... and a little more civilized," "with only one family with three persons." 175 Though Helma was initially unpaid, her work clearly had its perks. One can imagine that Helma's work instilled in her a sense of purpose but also personal power in lieu of the many circumstances which were beyond her. Her job soon advanced beyond clerical activities, and she came to interview parents' for vacations and helped a children's holiday transport (to Switzerland). Her volunteer duties also paved the way for opportunities to perform paid work, with which she was involved by the spring. Through her experience, Helma was able to secure jobs for the future if immigration was further delayed or if the 'Canada plan' did not work out. However, the latter remained a priority, particularly due to Reinhard's employment difficulties.

In some respects, while the Krolls were at the camp, a near reversal of gender norms seems to occur. Though such an inversion may be misleading, it is a subject worthy of exploration. While Helma worked as a volunteer, Reinhard's spirit seemed quite low, in large part because of his inactivity. At one point, she observed that "he liked

\footnotetext{
${ }^{173}$ Reinhard Kroll to Eleonore Scholz. December 27, 1953. Book 1, p.34.

174 One Slovenian DP recalled "You ceased to be a person, and became a number." Anonymous interview, Wyman, p.108.

${ }^{175}$ Interview with Helma Kroll, June 20, 2005. Book 1, p.9; Helma Kroll, memoir, March 8, 2001. Book 1, p.29.
} 
the change" of going to the camp kitchen to peel potatoes and carrots. ${ }^{176}$ At the camp, Reinhard pinned his hopes on future work in Canada and spent time in preparation by reading forestry literature. While in West Germany, he worked little. Though he did manage to obtain work at the Hamburger Free Port through a "contact's" 'contact,' such employment had its drawbacks: the couple would "have to do some very serious arithmetic" before he proceeded, for only " $20 \%$ of his wages would go into [the Krolls'] pocket- the rest [they] would share $50-50$ with the labour office." ${ }^{177}$ Not only could Reinhard not locate work in his field, but this type of manual labour was much below the station of a man so well-educated and previously employed in skilled work. Plus, he would not even receive full wages. Understandably, Reinhard's lack of suitable employment detrimentally affected his morale, especially because he was accustomed to the role of sole breadwinner. Helma writes of an annual meeting with other Foresters to which Reinhard has been invited, and that she hopes it "will give him a bit of a life."

Reinhard's time as a dock worker was brief because of his responsibilities at home. While Helma worked at the Red Cross, her husband looked after the children outside of school hours. There are also numerous instances in which Helma left Reinhard with the children for overnight visits to her friends outside the camp, so that she could get away. The Krolls' correspondence, particularly as it relates to the children, offers an excellent opportunity to explore the nature of the Kroll marriage. For the most part, their letters reflect a spirit of cooperation, in which one partner alternated with the other in providing a mainstay of support in times of difficulty. Yet, where gender roles are

\footnotetext{
${ }^{176}$ Helma Kroll to Elfriede Kroll. October 23, 1953. Book 1, p.27.

${ }^{177}$ Excerpt from letter "sent to relatives." (dated between November 2, 1953 and November 29, 1953), Book 1, p.29.

${ }^{178}$ Excerpt from letter "sent to relatives." (dated between November 2, 1953 and November 29, 1953), Book 1, p.29.
} 
concerned, one wonders how Reinhard felt about his wife's external position, particularly when he himself did not have consistent work. There is a curious double entendre in certain instances when he refers to Helma's work: he states that she "took on more than she should have in her volunteer work at the Red Cross. She has the ghastly habit like young horses, to attack mountains a gallop and runs out of steam in the middle of them." When Helma starts knitting more, Reinhard says "that would mean to cut back on the work at the Red Cross. I am all for it!” Although this might seem somewhat patronizing, it could also be read as a sign of concern, particularly because it comes after several months of Helma's volunteer position, during which time Reinhard is very supportive of his wife's escapes. With regards to these visits, Reinhard states that Helma "needed a break," which suggests an honest appreciation of her work, and perhaps even recognition of the taxing demands that 'double duty' entailed. ${ }^{179}$

In spite of the contradictory evidence, I would still maintain that the marriage appears to be a strong partnership endowed with mutual respect and belief in one common goal: Helma writes of their relationship "we are lucky, we understand each other and are pulling together on one rope. We agree on how to handle our children. Otherwise, we would have to throw in the towel. ${ }^{180}$ For the most part, the Krolls' marriage seems 'progressive,' particularly in light of contemporary gender norms: not only does Reinhard 'okay' Helma's application for work, but he also performed childcare duties. ${ }^{181}$ In a sweet display, Helma even came home to find her "good Reinhard was just braiding Beate's hair." Nevertheless, given Helma's relative surprise at Reinhard's hairstyling skills, there is an implication that this was not his regular role within the household.

\footnotetext{
${ }^{179}$ Reinhard Kroll to Richard and Elfriede Kroll. March 1, 1954. Book 1, p.37.

${ }^{180}$ Helma Kroll to Elfriede Kroll. October 23, 1953. Book 1, p.27.

${ }^{181}$ Helma Kroll to Eleonore Scholz. April 29, 1954. Book 1, p.43.
} 
Helma performed the traditional household tasks such as meal preparation, the mending of clothing, and the provision of laundered clothing to her "poor husband... in need of a clean shirt." ${ }^{\prime 182}$ She was also the regular secretary of letters to their family, which in part explains the detailed description of living arrangements and household activities, and the lack of specific discussion of other spheres. ${ }^{183}$ This division of duties suggests that although Reinhard now functioned outside his usual position, he still worked within some sort of gendered borders.

Yet, ultimately, camp life upset the traditional gender roles to which the Krolls had previously adhered in the past. Helma's testimony confirms this when she refers to the period in which she was hospitalized. Upon her return from a Red Cross trip with refugee girls, Helma became very ill, with what was diagnosed as hepatitis. The sheer logistics of the camp produced the rapid spread of illness. Helma's and Reinhard's letters abound with accounts of sickness in all of the Krolls - the flu, whooping cough, measles, mumps, and later for Helma, hepatitis - challenging the family in living space, time, and spirit. So frequent was illness that in one letter, Helma makes a point to note that "in the moment none [in] the family are sick. I wish it could stay like it for a while." ${ }^{\prime 184}$ Illness created major disruption in such a confined space, which was exacerbated by the threat of camp quarantine in the case of such infectious diseases as the mumps (though the Krolls avoided this due to an understanding worker). ${ }^{185}$ However, Helma's illness upset daily life to a new degree; she was hospitalized for nearly two months, which "shattered all [the

\footnotetext{
${ }^{182}$ Helma Kroll to Eleonore Scholz and her mother, Helene Schmitt. March 3, 1954. Book 1, p.38.

${ }^{183}$ No Place Like Home: Diaries and Letters of Nova Scotia Women 1771-1938 Margaret Conrad, Toni Laidlaw, and Donna Smyth, eds. (Halifax: Formac Publishing Company Limited, 1988), p.4.

${ }_{184}$ Helma Kroll to Elfriede Kroll. February 2, 1954. Book 1, p.35.

${ }^{185}$ Helma Kroll to Eleonore Scholz. November 29, 1953. Book 1, p.29.
} 
Krolls'] plans and prospects" by further delaying their immigration. ${ }^{186}$ With regards to their family life, Helma's illness necessitated that Reinhard cross the 'boundaries' of his previous role, and take on the full-time burden of Helma's domestic duties in her absence.

Helma was hospitalized "with tears in her eyes" at the beginning of June. ${ }^{187}$ Reinhard did not want to be the sole caretaker of their two small children and so he immediately tried to "get the two little ones into a day care, to get a bit more space for [himself]. ${ }^{.188}$ However, such daycare did not become available, though throughout Reinhard's letters he maintains his hope for such an opening. In the meantime, he states "I think it is healthy for me to be a 'straw-widower' for a time and have the whole bunch on my neck." This is a suggestive image which ostensibly compares the children to a burden not unlike a yoke. ${ }^{189}$ It is during Helma's illness that Reinhard, as an author, truly emerges. In Helma's absence it is up to him to report to their parents, and one can see a discernable difference in both the length and detail of his correspondence as compared to the previous letters penned by his wife. ${ }^{190}$ Though this discrepancy might be explained by his additional responsibilities as a 'single' parent, in context of the few other letters Reinhard wrote within the collection, it appears that for the most part, letters from him were short. During Helma's time in the hospital, Reinhard writes brief notes to his parents and mother-in law, mentioning tidbits such as watching Gerd swim at the pool, his wife's slow recuperation, and the status of their job applications ("not much success"). ${ }^{191} \mathrm{He}$ also includes incidents at home, such as one in which the children were playing while he

\footnotetext{
${ }^{186}$ Reinhard Kroll to Eleonore Scholz. June 1, 1954. Book 1, p.45.

${ }^{187}$ Reinhard Kroll to Eleonore Scholz. June 1, 1954. Book 1, p.45.

188 One could optimistically attribute his reluctance to his painful tooth abscess, or a simple disinclination to be both mother and father to his three children.

${ }^{189}$ Reinhard Kroll to Eleonore Scholz and her mother, Helene Schmitt. June 8, 1954. Book 1, p.46.

${ }^{190}$ See the collection of letters dated between June 1, 1954 and July 1, 1954.

191 Reinhard Kroll to Eleonore Scholz. June 3, 1954. Book 1, p.45.
} 
was at the hospital, and Hartmut struck his head on a bed. This "good scare" suggests that Reinhard may not have appreciated how much trouble his children could find when left to their own devices. ${ }^{192}$ Helma certainly realized the load which full-time parenthood entailed. Upon hospitalization, she minimizes her own situation and writes that "it is much worse for my Reinhard, who has to look after the children." 193 In a revealing letter to her mother-in law, Helma writes

My poor husband really has too many things to worry about in the moment. First I went for ten days to lead this girls camp (which brought us DM 50). then I came home with the flu, and now I am in the hospital with jaundice. He must be depressed. Besides, he is nursing a painful abscess on a tooth, and is not very patient. Sometimes it is really too much at once. But Mutti, as you said, the hardest time is behind us. Most of our job applications we got back with friendly 'sorry' letters. If you want mail, write job applications. ${ }^{194}$

Here, several undercurrents need to be recognized. First, Helma's concern primarily lies with her husband; she attributes much of his suffering to the stress both her job and her illness have caused. Again, she virtually ignores her illness, and instead focuses on her husband's hardship. The former may be an effort to minimize her mother-in law's potential worry, or it may simply illustrate that Helma's concerns revolve around others. The latter clearly demonstrates that she considers full-time childcare above and beyond Reinhard's duties. She also tries to maintain a degree of optimism, which could be further interpreted to relieve her mother-in-law of any stress, or, it could also be a personal coping mechanism for Helma in which she herself finds solace. In addition, Helma acknowledges the search for employment, which both she and her husband had pursued.

\footnotetext{
${ }^{192}$ Reinhard Kroll to Richard and Elfriede Kroll. June 13, 1954. Book 1, p.48; On an interesting note, Reinhard's letter to Helma's mother and grandmother was relatively dismissive of this episode, while his letter to his parents is much more descriptive.

${ }_{193}$ Helma Kroll to Eleonore Scholz. June 1, 1954. Book 1, p.45.

${ }^{194}$ Helma Kroll to Elfriede Kroll. June 4, 1954. Book 1, p.46.
} 
It is interesting to note that by the end of June, Helma has actually been offered a five month position in the West, while Reinhard is still unable to find work in his field.

While Helma was ill, Reinhard regularly visited her, both with and without the children, and got "from Helma instructions for the children" in exchange for gifts sent through the mail, and news from home. ${ }^{195}$ Helma's household tasks did not cease while in the hospital: after four weeks of bed rest, she had completed "all the mending for the family" and knit two sweaters. ${ }^{196}$ Reinhard took up the slack however. In essence, he now performed a genuine double duty, with 'supervision' from a distance by his wife. He carried on his old role: he continued his job search, the immigration proceedings, and secured for Gerd both funding and a place in the public high school, should their immigration be postponed past the fall; in addition, Reinhard also took on a new role within the home. ${ }^{197}$ Reinhard's letters are sparse and he does not elucidate his daily tasks at home; however, one presumes that as the primary caregiver, he lived up to his responsibility and tended to both the children's physical and emotional requirementsincluding their washing, dressing, needs for affection and discipline, in addition to other 'regular' household chores. Helma's 'regular job' offered Reinhard a challenge: for his children who were "eating like caterpillars" he cooked "rhubarb with cinnamon and lots of sugar. Tasted good - but somehow it didn't...." ${ }^{\prime 98}$ Here, he is likely referring to other events which were impinging upon the family's enjoyment such a treat: Hartmouth's

\footnotetext{
${ }^{195}$ Reinhard Kroll to Eleonore Scholz. June 13, 1954. Book 1, p.47.

${ }^{196}$ Helma Kroll to Richard and Elfriede Kroll. June 28, 1954. Book 1, p.49.

${ }^{197}$ Reinhard eventually managed to find a mother to look after the children should he be "on the tour." He does not explain this term but I would suggest relates to the working at the docks or in the midst of immigration proceedings.

${ }^{198}$ In the English collection, this latter phrase reads "but somebody was missing." Reinhard Kroll to Richard and Elfriede Kroll. June 13, 1954. Book 1, p.48. This translation was verified by Bob Harris in January 2006 . He concluded that "but somebody was missing" was incorrect, and that it actually reads "... with cinnamon and lots of sugar. It tasted good and somehow it didn't." He and Inge Harris agree that the implication here is that the food would have tasted better if there were no other events to spoil it.
} 
injury and Helma's absence. These household tasks were ones which Reinhard was not accustomed to performing; moreover, he missed sharing the load with his customary partner and companion.

Throughout the Krolls' stay in Wentorf, they kept their sights upon the ultimate goal: immigration to Canada. They practiced their limited English. Reinhard had received English training in school, and although not fluent, was much better than Helma. He taught (a reluctant) Gerd in the evenings, and also played the board game "Sorry" with the younger children, counting the squares in English. Gifts for their room at the refugee camp were received with consideration of their permanent place in a future Canadian home, and similarly, merchandise was purchased keeping in mind the practical use Canadian life. The Krolls accumulated goods which they imagined would be helpful to them in Canada: dishes, pots, pails, kitchenware, sheets, and blankets - “anything we can take will help us over there"-according to Helma. ${ }^{199}$ Two of their major purchases were made with borrowed money from family and friends: the first was a knitting machine, which the Krolls considered "a good investment for Canada" because Helma "could start to pay back the costs" of their voyage before they even left, and once in Canada, she could "do [her] part of making money by knitting for the Canadians." 200 Their second large purchase was a motorcycle — "an older machine with a sidecar;" it would "transport [Reinhard] and [his] luggage and might be easier to handle on ice," and in addition, would hopefully help Reinhard attain and maintain employment in Canada (as advised by

\footnotetext{
${ }^{199}$ Helma Kroll to Elfriede Kroll. February 2, 1954. Book 1, p.35.

${ }^{200}$ Helma and Reinhard Kroll to Eleonore Scholz and Richard and Elfriede Kroll. April 17, 1954. Book 1, p.42. Note that Helma seems to be the speaker, which suggests that she was the author of this letter, not just the secretary.
} 
their friend Hubert Hundreiser). ${ }^{201}$ For the most part, the goods they accrued were practical. However, one notable exception was pictures and paintings by family members: pieces of family history which would link them to their past and loved ones, in a new land.

The Krolls' preparation had began early in their camp life, but accelerated throughout their stay. Hubert Hundreiser, their friend who had previously immigrated to Canada, played a significant role in the Krolls' optimism, preparation, and ultimate immigration. His energetic letters "lifted [the Krolls'] spirits a lot;" as he filled out paperwork on the Canadian side, they consistently rallied the Krolls' hopes for the future. ${ }^{202}$ I would suggest that Hundreiser's enthusiasm contributed to the Krolls' optimism, as he was persistent with both his efforts and letters of support. It was through his sponsorship that the Krolls were able to immigrate (or it at least it played a tremendous role in the process); he took full responsibility for their welfare and accommodation once in Canada, and also provided the Krolls' with a source of confidence and encouragement.

This encouragement was much needed, for as has been previously outlined, the Krolls faced many delays. After Reinhard's interview with the Canadian authorities in March, the immigration proceedings are not mentioned except in relation to Helma's unexpected illness. At the end of April, Helma and Reinhard were still looking for work within the FRG, "but only for a limited time, Canada still [was] the main destination."203 They maintained their optimism. However, in June Reinhard expressed deep dismay at Helma's untimely illness, which would upset their immigration plans. Nonetheless, they

\footnotetext{
${ }^{201}$ Reinhard Kroll to Richard and Elfriede Kroll. April 16, 1954. Book 1, p.41.

${ }^{202}$ Helma Kroll to Elfriede Kroll. June 23, 1954. Book 1, pp.48-9.

${ }^{203}$ Helma Kroll to Eleonore Scholz. April 29, 1954. Book 1, p.43.
} 
had no other choice but to recover emotionally from this impediment, and await Helma's physical recovery. At the beginning of July, after receiving Hundresier's letter, Helma writes "if we can make it, we will...start in the fall. Why delay it any further." 204 Upon Helma's release from the hospital, Reinhard fills his parents in on the recent progress, which occurred that very day. The family underwent a 'superficial' check-up; there was one 'hiccup' due to a previous case of pleurisy Helma had had, but the Canadian doctor decided that yearly check-ups in Canada would suffice. Following this, Reinhard writes "we had to sign two forms, which were attached to our papers. [The doctor] kept our passport, we got an English grammar book and left on an "up-beat." They subsequently had to wait for their papers to return from Berlin, but in the meantime, they went to "the church organization" which Reinhard writes "will pay our trip and maybe help with some job hunting. ${ }^{, 205}$ It is telling that the name of the church organization is not mentioned in the letters and vaguely referred to in Helma's oral testimony. In response to a direct question, she states "I think it was the United Church, I don't know." 206 The processing of applications for passage cost could take up to four weeks for processing; Yet, once it was underway, the Krolls were "optimistic and thinking that everything [would] work out."207 A few days later, they received "a call from the Canadians" that their landed immigrant visa had gone through. Now, all that remained was for their application to be sent to the officials in Canada, who would get in contact with Hundreiser, in order to ensure his sponsorship. From here on, there was another four to six weeks wait to receive the paper work, and then another week until a placement on a ship.

\footnotetext{
${ }^{204}$ Helma Kroll to Eleonore Scholz. July 1, 1954. Book 1, p.49.

${ }^{205}$ Reinhard Kroll to Richard and Elfriede Kroll. July 28, 1954. Book 1, pp. 50-1. The money was actually a loan.

${ }^{206}$ Interview with Helma Kroll, June 20, 2005. p.15.

${ }^{207}$ Reinhard Kroll to Richard and Elfriede Kroll. July 28, 1954. Book 1, p.51.
} 
The Krolls began the final preparations for their departure. Materially, they partook in some last minute shopping - aided by a separation gift of 1000DM from the government and a small loan from Reinhard's parents. In preparation for the emotional separation, Helma and Reinhard went on the road with Reinhard's motorbike to say goodbye to family and close friends. Of the latter, one was also a former forester from the East, who waited up to fifteen years for the same position in the FRG. ${ }^{208}$ Likely, this would have reaffirmed any existing doubts the Krolls may have had; their friends too hoped to come to Canada. Both Helma's mother and Reinhard's parents visited them before their departure. ${ }^{209}$ They said their final farewells, and the women spent hours packing in preparation for the big move.

Within the time leading up to the Krolls' departure there is a sense of urgency and business, which is reflected in their letters. Helma and Reinhard are on the go, trying to tie up loose ends before they leave Germany. There is a marked change in the tone of their correspondence; it is less frequent, more eventful, conveys a new optimism, and an impression of being actively occupied towards their final goal, which is about to be realized.

A week after the senior Krolls' visit, Helma wrote to her mother "We made it! The ship will leave at $1 \mathrm{pm} . " 210$ Reinhard inserted his brief note "I am wishing you both all the best and 'thank you'!" On this final note, their ship left. ${ }^{211}$

\footnotetext{
${ }^{208}$ Reinhard Kroll to Richard and Elfriede Kroll. August 20, 1954. Book 1, p.54.

209 As pensioners, the senior Krolls could visit the West and return without risk.

${ }^{210}$ Helma Kroll to Eleonore Scholz and her mother, Helene Schmitt. September 17, 1954. Book 1, p.57.

${ }^{211}$ Reinhard Kroll to Eleonore Scholz and her mother, Helene Schmitt. September 17, 1954. Book 1, p.57.
} 


\section{Chapter Four: A House and Home}

"With some trepidation we think of the future and look forward to a day when we will not just be part of an assembly line. We leave our old homeland behind with scarcely a backward glance."

The Krolls came to Canada with the desire to begin again. They left Germany behind and put all their hopes into a new future, in a country about which they knew very little. With few alternatives, the Krolls moved forward with the willingness to work from scratch and start anew--like 'pioneers. ${ }^{2}$ However, just as the refugee experience had offered the Krolls new challenges on a daily basis, so too, did their immigration experience; it transformed their mode of living and challenged their resourcefulness to an extreme. In Canada, the Krolls encountered a material culture which enforced their inferior status in a consumer-driven order. They faced economic challenges which altered their gendered roles within the family, and called into question their self-identity as it pertained to class, status, and work. As immigrants outside of the 'receiving society,' they also grappled with questions of ethnicity. The Krolls' self-identity evolved during their first few years on Canadian soil; while they retained expressions of their German roots, they also incorporated aspects of 'being Canadian.'

It is without doubt that the Krolls, like numerous other immigrants, faced an array of challenges and years of hard work upon immigration. However, despite hardships, the Krolls preserved that which they valued the most: their family. In Canada, Reinhard and Helma not only found 'freedom,' but they had the opportunity to give their children a better future. Their family unit maintained its integrity throughout immigration, and was the source of motivation for hard work and perseverance during periods of struggle.

\footnotetext{
${ }^{1}$ Reinhard Kroll to Eleonore Scholz and Richard and Elfriede Kroll September 27, 1954. Book 1 p.59.

${ }^{2}$ This term is employed by other postwar immigrants as well. For example, Jean Bruce, "No Room for Two Women," After the War, (Ontario: Fitzhenry and Whiteside, 1982), p.166.
} 
Furthermore, although the Krolls lost physical access to their parents through immigration, this connection remained intact - it was just altered. Helma's oral testimony emphasizes the family, but above all, it is the Kroll letters which speak to its prioritization in the Krolls' life. Not only do the letters stress the importance of the children to Helma and Reinhard, but the very existence of the collection indicates that the relationship continued to be a vital part of the Krolls' lives. This chapter will examine the Krolls' experience as 'New Canadians.' It will address the economic and material challenges they encountered, which influenced their sense of self and roles within the household, and, it will explore issues of ethnicity, language and culture. Finally, it will look at the Krolls' resourcefulness and optimism in making a new life for themselves, as a family, in Canada. Such an analysis is grounded primarily in Helma's oral testimony and the collection of letters which she and her husband wrote throughout their first years as immigrants. Thus, this chapter will concurrently interrogate the nature of these sources. With regards to oral testimony, it will ask how the past is constructed by Helma's memory; with regards to the letters, it will query how their writing varied according to author-Helma or Reinhard — and how their content was shaped by the relationship with the recipients - their parents.

The Krolls were five of 850 immigrants who set sail to Canada on September 17, 1954. ${ }^{3}$ Upon seeing "the land of [their] future," they were enthralled. ${ }^{4}$ The family was received in Quebec City by a German-speaking representative of the church, who whisked them through customs, into a taxi, and onto the train that would bring them to Ottawa. Helma wrote that once aboard the train,

\footnotetext{
${ }^{3}$ Reinhard to Eleonore Scholz and Richard and Elfriede Kroll. September 25, 1954. Book 1 p.57.

${ }^{4}$ Reinhard to Eleonore Scholz and Richard and Elfriede Kroll. September 27, 1954. Book 1 p.59.
} 
a steward came, Reinhard tried out his English, our children got their first Coca Cola and the parents tea. We tried out the 'wonderful' washroom, it was an experience we did not expect, even ice water free with small paper cups, and a garbage can right beside it. Everything was so clean, I will never forget it. $^{5}$

Here, just as in Beate's oral testimony, the importance of food and material goods is illustrated in Helma's contemporary retelling of her experience. It must be borne in mind that the Krolls had only just emerged from the refugee camp. During this year, they had "learned a lot. Tolerating many things, including standing in line, waiting, being a number only, bunk beds etc., and we did not expect much." ${ }^{.6}$ The 'luxurious' conditions on the train provided a great contrast to those which the Krolls had recently experienced. Yet, in many respects, these difficult conditions would serve them well in Canada: as new immigrants they were able to afford little, and the challenges that they encountered in their next few years would be trying. ${ }^{7}$ Despite hardships and stress, the Krolls persevered with relative optimism. Though this optimism was at times staged for the benefit of their parents, the Krolls gained from it as well. In addition to their recent experience in austere conditions, they felt "there was no choice" but to proceed given that they "really didn't have a home in Germany." 8 Moreover, by writing with a positive attitude when conditions were difficult, the Krolls likely transformed this sentiment into a reality. ${ }^{9}$

\footnotetext{
${ }^{5}$ Helma Kroll to Eleonore Scholz and Richard and Elfriede Kroll. October 4, 1954. Book 1 p. 61. ${ }^{6}$ Helma Kroll to Eleonore Scholz and Richard and Elfriede Kroll. October 4, 1954. Book 1 p. 60.

${ }^{7}$ Milda Danys' DP Lithuanian Immigration to Canada After the Second World War (Toronto: Multicultural History Society of Ontario, 1986.) echoes this notion with regards to Lithuanian DPs. Danys, p.244.

${ }^{8}$ Interview with Helma Kroll, August 9, 2005 pp. 17, 11.

${ }^{9}$ Dehaan, Kathleen A. "Wooden Shoes and Mantle Clocks': Letter Writing as a Rhetorical Forum for the Transforming Immigrant Identity," Alternative Rhetorics: Challenges to the Rhetorical Tradition. Laura Gray-Rosendale, Sibylle Gruber, eds. (Albany: State University of New York Press, 2001), p.55; Jerome Bruner as cited by David A. Gerber, "Epistolary Masquerades: Acts of Deceiving and Withholding in Immigrant Letters," Letters Across Borders: The Epistolary Practices of International Migrants. Bruce S. Elliot, David A. Gerber and Suzanne Sinke, eds. [New York: Palgrave, 2006 (forthcoming)], p.6. (with reference to untruths; both helpful to writer and recipient.)
} 
In Canada, the Krolls once again inhabited crowded accommodations-though this time, with friends. They were met at the train station by Annelotte Hundrieser, in whose home they would spend their first eight weeks in Canada. It was with the Hundreisers that the Krolls first experienced Canada, learned the 'ropes' as far as the Hundreisers' experience would allow, and took their first steps. The Hundreiser's 'tiny, tiny cottage," was "un-insulated, without a heating system or anything;" it was very crowded for eleven people, but the families had "a good understanding with each other." ${ }^{10}$ Similar to the experience of many Italian immigrants, Helma and Annelotte cooked with each other, and the families shared household responsibilities. ${ }^{11}$ The Hundreisers were an important key to the Krolls' immigration: not only did they sponsor Helma and Reinhard, but more importantly, they carried out their responsibilities to aid in the family's initial settlement, acting as friends as well as sponsors.

The continuing friendship with the Hundreisers both supported the Krolls as a family unit and maintained links with a familiar German culture. Co-incidentally, during the Atlantic crossing, the Krolls had befriended a Mrs. Brettschneider, who was meeting her husband in Canada. Mr. Brettschneider had also stayed with the Hundreisers in order to get established in Canada before his wife and children arrived. This split migration had been an option for the Krolls, yet, while Helma admits that "It would maybe have been much, much easier if [her] husband had come first and [she] stayed... [she] didn't want to be separated from [her] husband." 12 That the Krolls chose to stay together as a family unit

\footnotetext{
${ }^{10}$ Interview with Beate Myhill, June 20, 2005.p. 15; Helma Kroll to Eleonore Scholz and Richard and Elfriede Kroll. October 4, 1954. Book 1 p. 59.

${ }^{11}$ Franca Iacovetta, Such Hardworking People: Italian immigrants in postwar (Toronto. Montreal: McGillQueen's University Press, 1992), p..89; Helma Kroll to Eleonore Scholz and Richard and Elfriede Kroll. October 16, 1954. Book 2 p.5.

${ }^{12}$ Interview with Helma Kroll, August 9, 2005 p. 17. Gertrud Jaron Lewis' article "The German Woman Immigrant in Northeastern Ontario." (Annals: German-Canadian Studies 5 (1983): 143-166) offers an
} 
(and sacrifice Reinhard's career opportunities in the process) testifies to their overriding commitment to the family, which reappears throughout their story. Nevertheless, social contact beyond the family was also important; the Hundreisers filled this role too, providing companionship, support and understanding for both Helma and Reinhard.

The Krolls' initial contact with Canadians was positive. As has been previously stressed, Canada's decision to open its gates to Germans in 1950 was fueled primarily by political and economic motives. The rapid decline in public hostility to Germans in the Cold War climate facilitated the admissions of new immigrants from Germany. ${ }^{13}$ Nevertheless, Canadian prejudice was also influential, and worked in their favour as compared to other immigrant groups. As early as 1946, a Gallop poll reported that $60 \%$ of Canadians opposed immigration of the Japanese, $49 \%$ Jews, 34\% Germans, $31 \%$ Russians, 31\% 'Negroes', 25\% Italians, and 24\% Chinese. ${ }^{14}$ Significantly, Jews, who were generally regarded as the targeted victims of the war, were ranked less desirable by Canadians for entry than the Germans, who had so recently been sworn enemies. ${ }^{15}$ As with Italian and Japanese immigrants, racial prejudice played a large role in anti-Semitic discrimination. In a poll one year later, when asked how they felt about Germans, $41 \%$ of Canadians felt friendly towards them and $25 \%$ felt indifferent. By 1952 , these numbers

excellent account of the life that Helma could have encountered, if Reinhard had traveled ahead, and taken work in a Northern mining or forestry town. Seemingly, Helma felt she needed Reinhard for support, and as was discussed in Chapter 3, this feeling was mutual. Witnessing the German woman with three children, who came to meet her husband, there is a sense of gratitude when Helma writes "I have my Reinhard." (Book 1 p.58.)

${ }^{13}$ Gerhard P. Bassler, "German-Canadian Identity in Historical Perspective," A Chorus of Different Voices. Angelika E. Sauer and Matthias Zimmer, eds. (New York: Peter Lang, 1998), 92.

${ }^{14}$ Schmalz, p.46; Jean Bruce, After the War., p. 14.

${ }^{15}$ For a thorough account of the Jewish experience through Canadian immigration, see Irving Abella, and Harold Troper, None is Too Many: Canada and the Jews of Europe 1933-1948. (Toronto: Lester \& Orpen Dennys, 1982), 
had increased to $52 \%$ and $26 \%$ respectively. ${ }^{16}$ In October 1949 , an official from the Immigration branch wrote that "there is no doubt that Germans have made good citizens;" he went on to declare that "the subject of German immigration... [is] one on which there is a divergence of opinion. Frankly, the bulk of opinion expressed to me by veterans has been that there should now be a relaxation in the regulations so as to permit German immigration - particularly of close relatives." $"$ This suggests that even for combatants, memories from the recent war were fading quickly with respect to Germans. With the establishment of the Cold War, the Russians were Canada's new enemies, and those who opposed (or were victimized by) the 'Reds' were allies, regardless of their history. In fact, by the late $40 \mathrm{~s}$, the Canadian press capitalized upon such stories as the Krolls', and regularly featured tales of dramatic escape from the Iron Curtain. Such narratives described a life of danger and oppression in the East, and culminated with the Europeans' discovery of refuge, safety, and freedom on Canadian soil. Thus, they served to both affirm the horrors of Communism and confirm the decency of democracy in the process, and they manufactured a feeling of good will towards these new arrivals. ${ }^{18}$

In her oral testimony, Helma is reluctant to discuss episodes of discrimination. She seems anxious to portray a positive and grateful attitude towards Canada; similarly, negative experiences caused by her Germanness are also absent from both her and

\footnotetext{
16 “Gallop Poll: Bitterness Against Germans Waning Among Canadians" Montreal Star, Saturday, November 151952.

${ }^{17}$ Letter to D. Anderson, General Secretary Canadian Legion from Colin Gibson. RG26 Vol 115 3-24-18 "Canadian Legion and Other Veterans Associations Correspondence with On Immigration"

${ }^{18}$ Franca Iacovetta, "Making Model Citizens: Gender; Corrupted Democracy, and Immigrant and Refugee Reception Work in Cold War Canada," Whose National Security? Canadian State Surveillance and the Creation of Enemies. Gary Kinsman, Dieter K. Buse, Mercedes Steedman, eds. (Toronto: Between the Lines, 2000. 154-167.) pp.157-9; Also see Franco Iacovetta, Gatekeepers: Reshaping Immigrant and Refugee Lives in Cold War Canada. (Between the Lines, forthcoming). Chapter 1.
} 
Reinhard's written correspondence. ${ }^{19}$ Because Germans were recruited by the Canadian

government as workers, it is entirely plausible that the Krolls gave potential

discrimination very little thought. Nevertheless, though rare, it did arise, particularly in

the lives of the Kroll children. Beate recalls incidents of playground taunting in which she

and her siblings were associated with Nazis; perhaps even more striking, she also

recounts an experience in which Hartmuth was specifically targeted by a teacher who ridiculed him in relation to his Germanness. ${ }^{20}$ That notwithstanding, on the whole, the Krolls' testimony concurs with that of other German immigrants: they were taken aback by the friendly manner with which their Canadian neighbours treated them. ${ }^{21}$

Of the 154,227 immigrants who came to Canada in 1954, the Krolls were 5 of 28,360 German nationals. ${ }^{22}$ Between 1946 and 1960, 12.5\% of Canada's immigrants were defined as German in terms of ethnicity. ${ }^{23}$ The 'German boom' occurred between 1951

\footnotetext{
${ }^{19}$ In Helma's testimony, there is an apparent reluctance to discuss the negative encounters with discrimination, or negative experiences on the whole. One cannot help but wonder how she constructs her memories, and what she chooses (consciously or unconsciously) to leave out. Perhaps this is an effort to maintain a face of gratitude In Barry Broadfoot's The Immigrant Years: From Europe to Canada 1945-67 (Vancouver: Douglas \& McIntyre, 1986) one immigrant attempts to censor herself when describing the very difficult conditions which she met in Canada. She states "Oh, I shouldn't say this," although it is obvious that her situation was very difficult, she attempts to put a positive spin on her experience. There is an apparent struggle between her memory and the image she wants to convey-seemingly one of gratitude and loyalty. She goes on to tell her story, starting with "The rest was not too bad, although it was still pretty awful." Broadfoot, pp.180-1.

${ }^{20}$ Beate recounts Harmouth's experience. "My brother walked on the wrong side of the hall. Actually, he was walking on the right side of the hall but he didn't do a right turn to go into the classroom, he cut the corner and did a 45 degree turn to go into the classroom. And the science teacher caught him doing it. So the science teacher took him into the science room and made him crouch under the flower shelf by the window in the crouching position, an $\mathrm{d}$ made him stay there all day, and ridiculed him with every class that came in....It was Little German immigrant, we're going to teach you to follow the rules..." Interview with Beate Myhill, June 20, 2005. p. 21.

${ }^{21}$ See Petra's story amongst others, in Gisela Forchner, "Growing Up Canadian: Twelve Case Studies of German Immigrant Families in Alberta." PhD thesis. (University of Alberta, 1983), p.68.

${ }^{22}$ German nationals were defined as individuals who had FRG citizenship. The FRG included both West German and East German citizens as its residents; even those East Germans who immigrated to Canada needed to come through the West, as there were no Canadian Immigration Missions behind the Iron Curtain. 1954-55 Annual Report Department of Citizenship and Immigration Ottawa: Queen's Printer and Controller of Stationary, 1955. pp.28-9.

${ }^{23}$ The Migration of Professional Workers Into and Out of Canada 1946-1960. Economics and Research Branch, Department of Labour. (Bulletin No.11, p. 13, Table 3. October 1961.) Until 1953, this number
} 
and 1957, a period in which German national immigrants were outnumbered only by the British. ${ }^{24}$ Overall, postwar German immigrants were fairly young, often with families, and they had more education than those of other ethnic groups. ${ }^{25}$ Germans generally came through immigration labour schemes, in an effort to supply the Canadian economy with badly needed domestic servants, miners, and agriculturists. ${ }^{26}$ They were regarded as reliable workers, and were often specifically requested by Canadian businesses and employers. $^{27}$

Unlike many postwar immigrants, the Krolls did not migrate to one of Canada's large urban centres. Instead, through their friends the Hundreisers, they came to Manotick, a small community outside of Ottawa with a mere 500 residents. $^{28}$ The Krolls' destination point undoubtedly influenced their immigration experience. In comparison to a large city, Manotick's small size contributed to its warm, friendly, and helpful atmosphere; nonetheless, its population was overwhelmingly of Anglo-Saxon descent. Had the Krolls moved to Kitchener-Waterloo, a well-established German-Canadian centre, or even Ottawa, which had a more (albeit, limited and somewhat dispersed) German-Canadian community, their subsequent Canadian acculturation would likely have been very different. However, because of this ethnic absence, and the complications of reaching larger city centres (the Krolls did not own a car and public transportation was

also included Austrians. West Germans, East Germans, and some Swiss were also included in this statistic. Anthony H. Richmond cites this percentage as 12\% between 1945 and 1965. Anthony H. Richmond, Postwar Immigrants in Canada .(Toronto: University of Toronto, 1967.) Table 1.1, p.5.

${ }^{24}$ Ronald E. Schmalz, "Former Enemies Come to Canada: Ottawa and the Postwar German Immigration Boom, 1951-1957." Dissertation.(Ottawa: University of Ottawa, 2000), p.2.

${ }^{25}$ K.M. McLaughlin, The Germans in Canada. (Ottawa: Canadian Historical Association, 1985), p.17.

${ }^{26}$ For specific accounts of these immigrants' experiences, Alexander Freund, "Immigrants' Identities: The Narratives of a German-Canadian Migration" in A Chorus of Different Voices: German-Canadian Identities. Eds. Angelika E. Sauer and Matthias Zimmer. (New York: Peter Lang, 1998): 187-208; and Lewis, Annals: German-Canadian Studies.

${ }^{27}$ Schmalz, pp. 19, 29.

${ }^{28}$ Helma Kroll to Eleonore Scholz and Richard and Elfriede Kroll. October 16, 1954. Book 2 p.3. 
rather infrequent), the Krolls were physically distant from most of their compatriots, thus, they had to depend upon alternative sources of support, specifically ones 'Canadian.'

Of course, the critical role played by written correspondence must not be neglected in an assessment of the Krolls' immigration experience. Particularly in the initial stages of immigration, contact with loved ones was vital in maintaining a sense of continuity when the world around the immigrant was in flux. ${ }^{29}$ Though the Krolls used the church and the Hundriesers for support, the connection with their parents provided an ongoing source of stability. Pauline Grossenbacher Boss contends that "immigration is a systematic interactional phenomenon that never really ends. The family consists not only of the system left behind but, also, it includes, at least in their minds, the émigré who has gone to a new land." ${ }^{30}$ It was Reinhard's mother who was the most insistent about correspondence, and admonished the family when mail was infrequent. Nevertheless, Helma acknowledges that the family connection was critical for both her and her husband as well; it gave them much-needed contact with loved ones, and provided a sort of emotional sustenance. ${ }^{31}$ Transatlantic migration was an ambiguous loss, for neither the immigrant, nor those left behind knew when, or if, they would meet again. ${ }^{32}$ Letters provided a concrete link; they reaffirmed Helma and Reinhard's place in their respective families, providing a sense of familiarity. They also supplied emotional support through difficult periods, for which the Krolls' initial five years in Canada would undoubtedly

\footnotetext{
${ }^{29}$ Kathleen A. Dehaan,"'Wooden Shoes and Mantle Clocks': Letter Writing as a Rhetorical Forum for the Transforming Immigrant Identity," in Alternative Rhetorics: Challenges to the Rhetorical Tradition. Laura Gray-Rosendale, Sibylle Gruber, eds. (Albany: State University of New York Press, 2001), 67.

${ }^{30}$ Pauline Grossenbacher Boss, "The Experience of Immigration for the Mother Left Behind: The Use of Qualitative Feminist Strategies to Analyze Letters from My Swiss Grandmother to My Father," in Marriage and Family Review, 19, (1993): 368.

${ }^{31}$ Interview with Helma Kroll, August 9, 2005 pp.13-14.

${ }^{32}$ Boss, Marriage and Family Review, 19(1993):;368.
} 
qualify. ${ }^{33}$ They were markers of progress, support in times of difficulty, and reminders

that Helma and Reinhard were remembered and not alone, in an environment, which

although not hostile was still foreign, at least in the beginning.

Like many other German immigrants, the Krolls knew "not much" about the country which they would soon call their own. ${ }^{34}$ Their limited information had come from the Hundreisers, who advised them on what to bring and had told them about the "amazing clotheslines, where you just stood at the window with the pulley system, and you could hang your laundry up without walking along the line outside." 35 The Krolls' first impressions of Canada were of course in contrast to Germany. Materially, socially, and culturally, the countries were different; however, it would be misleading to suggest that the Krolls found such differences overwhelming. ${ }^{36}$ On the contrary, though practices diverged, the Krolls stressed (particularly in oral testimony) that the two countries were not fundamentally different. Correspondence seems to support the present perception that the Krolls felt relatively at ease in their new homeland. Apart from a few alien practices, they were not alarmed by their new material environment, thus supporting the general

\footnotetext{
${ }^{33}$ Beate states "We always said to people 'the first five years are the hardest. If you can last it out through the first five years, it gets better." Interview with Beate Myhill, August 9, 2005 p.12.

${ }^{34}$ Interview with Helma Kroll, June 20, 2005. p.15; Alexander Freund, "Immigrants' Identities: The Narratives of a German-Canadian Migration," A Chorus of Different Voices: German-Canadian Identities. Eds. Angelika E. Sauer and Matthias Zimmer. (New York: Peter Lang, 1998),195. Many German immigrants thought "Canada is just like America." It is interesting to note that in a poll of Germans emigrants, $47 \%$ wanted to go to USA, $20 \%$ to Canada, and $10 \%$ to Australia. Wolfgang G. Friedmann, German Immigration into Canada. Contemporary Affairs-No.23. (Toronto: The Ryerson Press, 1951), p. 20.

${ }^{35}$ Interview with Beate Myhill, June 20, 2005. p.15.

${ }^{36}$ Differences of this sort are often the focus of such historical accounts. I approached the Krolls' story expecting to hear traumatic tales of culture shock, discrimination, and a rocky acculturation, but was disappointed; though these aspects were certainly addressed by the Krolls, they were not the primary focus, nor the dominant experience. One can speculate as to the reasons: a high rate of German assimilation, or the Krolls' own personal experiences which had gave them an especially optimistic vantage point, or the Krolls' particular ability to socialize with others, persevere and work hard, or, perhaps a combination of all three.
} 
observation that postwar German-immigrants integrated rapidly into Canadian life and society. $^{37}$

Nevertheless, as other immigrants have testified, it is often the performance of regular activities in "the average expectable environment" which reminds one of their foreigner status. ${ }^{38}$ For the Krolls, it was the 'little things' that comprised their "culture shock. ${ }^{, 39}$ Canada's post war economic boom had coincided with the explosion of consumerism; as European immigrants, the Krolls had left a land of austerity, and arrived in one of prosperity. ${ }^{40}$ Immigrant shoppers, particularly women, attest to the tremendous abundance and choice that they found in supermarkets and department stores, sometimes finding it overwhelming: they had "never seen so much all together!"41 Helma wrote home that "Shopping is quite an experience on its own. You can get everything in a big supermarket. ${ }^{, 42}$ Often accustomed to systems in which rations, status, and chance determined one's purchases, new immigrants were delighted by the easy access to goods in Canada-one only needed cash or credit! At the same time, they were shocked by the squandering of resources which were held dear in their homeland: "the waste on

\footnotetext{
${ }^{37}$ See Ralph Allen, "The Untroublesome Canadians," MacLean's 1964, 77, no.5 (1964), 19-21, 50, 52-3.

${ }^{38}$ H. Hartmann. Essays on Ego Psychology. New york: International Universities Press, 1964. as cited by Oliva M. Espin, "Roots Uprooted: The Psychological Impact of Historical/Political Dislocation," Refugee Women and Their Mental Health: Shattered Societies, Shattered Lives. Ellen Cole, Oliva M. Espin, Esther D. Rothblum, eds. (New York: Haworth, 1992), 13. This refers to the 'everyday' differences which in some respects, come to define 'uprootedness.' For example: food, smells, and other little things which can have a large psychological effect.

${ }^{39}$ Interview with Helma Kroll, June 20, 2005. p.15.

${ }^{40}$ Franca Iacovetta and Valerie J. Korinek, "Jello-O Salads, One-Stop Shopping, and Maria the Homemaker: The Gender Politics of Food," Sisters or Strangers: Immigrant, Ethnic and Racialized Women in Canadian History. Marlene Epp, Franca Iacovetta, Frances Swyripa, eds. (Toronto: University of Toronto Press, 2003), p.192.

${ }^{41}$ Both Hoffman [Eva Hoffman, Lost in Translation. (New York: Penguin, 1989), p.135] and Grossman comment on being overwhelmed by variety in the supermarket. "...the large repositories of consumerism...confronted with ten varieties of soap or toothpaste, I stand paralyzed, my capillaries tightening into a panicky headache." Grossman, p.86. Also, See Iacovetta and Valerie J. Korinek "Jell-O Salads," in Sisters or Strangers? : Immigrant, Ethnic and Racialized Women in Canadian History. Edited by Marlene Epp, Franca Iacovetta, Frances Swyripa. (Toronto: University of Toronto Press, 2003), 211; "Discovering the supermarket," Bruce, p.152.

${ }^{42}$ Helma Kroll to Eleonore Scholz and Richard and Elfriede Kroll. October 4, 1954. Book 1 p. 62.
} 
wrapping paper in the stores, in the grocery stores," string, and plastic bags, made a big impression. ${ }^{43}$ These 'small' things, which Canadians took for granted, were saved and reused repeatedly in Germany - even the brown paper with which meat was wrapped. ${ }^{44}$ Similarly, the frequency with which Canadians employed their vehicles also came as a big surprise; the Krolls found that they were the only ones on foot in contrast to Canadians who drove everywhere, even for short distances such as to the post office. ${ }^{45}$ Although it was written with regards to the clothesline, Helma's observation that "Not one step more than necessary, that is the principle" seems to apply to her general impression of Canadian life. ${ }^{46}$ Convenience seemed to be the expected standard whether in transportation or clothing. With respect to the latter, Helma commented that instead of buttons, "everything [was] held up and together with a belt or zipper," and in place of home-sewn clothes, store-bought blue jeans were the norm. ${ }^{47}$ On a social level, Canadians' mode of living was also less formal. Though the Krolls found Canadians "overwhelmingly friendly and welcoming," they were too 'generous' with their children, and did not work as hard as their immigrant counterparts. ${ }^{48}$

Social distinctions were not as marked as they were in Germany, particularly for the Krolls (especially Reinhard), who had been members of the upper class. Canadian society was more informal, the lines between those in authority and their 'common' fellows being much less discernible. At the local United Church, Helma noted that All 'church-life' is more down to earth. The minister's sermon is not as seriously presented as in our churches and when the priest takes off his robes, he is a person

\footnotetext{
${ }^{43}$ Interview with Helma Kroll, June 20, 2005. p.17.

${ }^{44}$ Interview with Beate Myhill, June 20, 2005. p.15.

${ }^{45}$ Interview with Helma Kroll, June 20, 2005. p.15.

${ }^{46}$ Helma Kroll to Eleonore Scholz and Richard and Elfriede Kroll. October 16, 1954. Book 2 p.4.

${ }^{47}$ Helma Kroll to Eleonore Scholz and Richard and Elfriede Kroll. October 16, 1954. Book 2 p.4.

${ }^{48}$ Interview with Helma Kroll, June 20, 2005. p.17; Reinhard Kroll to Richard and Elfriede Kroll.

December 18, 1954. Book 2 p.11
} 
like everyone else. He will wash his car, or go shopping for his wife in a self-serve store. $^{49}$

For some immigrants, the lack of social rigidity was very positive, for it provided the opportunity to become a 'self-made man' when in Europe a lack of bloodlines would have hindered them. ${ }^{50}$ Nevertheless, some newcomers found that Canadians did possess biases along social lines. As one Hungarian immigrant stated,

Canadians felt superior to us, because of the way we talked, the way we dressed, the things we ate. And we felt superior to them. We thought our education, our outlook so much broader, so much more sophisticated. Perhaps it was a mistake on both sides. They were very provincial and narrow-minded, and we were more limited than we realized. We knew European life and literature, but we didn't know much about North America. ${ }^{51}$

Helma and Reinhard would likely have been able to relate to the above testimony. Though European immigrants encountered prejudices, they too possessed them. As Helma states, "Certainly as a German, we knew a lot of things. 'We know and do better." 52 To many Europeans, Canada was perceived as 'the provinces,' lacking the level of sophistication to which many were accustomed. ${ }^{53}$ Such simpleminded-ness included both social organization and culture. Helma does not use the same harsh language as some other immigrants, who felt that Canada was a "cultural wasteland;" nonetheless, she concluded shortly after her arrival that "Ottawa, Canada's capital city" was "very rural." 54

It has not much character besides a lot of big cars. Here the teenager's dream for his future is a big car. We miss having any specialty stores. We only saw some big stores, that have everything for the daily shopping and some department stores.

\footnotetext{
${ }^{49}$ Helma Kroll to Richard and Elfriede Kroll. October 25, 1954. Book 2 p.6

50 “The Self-made Man," Bruce, p.165; also see "The Freedom to Get Ahead" in Broadfoot, pp.30-1.

51 "Unspoken Friction," Bruce, p.169.

52 Interview with Helma Kroll, June 20, 2005. p. 20.

${ }^{53}$ Interview with Beate Myhill, June 20, 2005. p.20; In Forcher's interviews with immigrant parents, this is a reoccurring theme. For example, see Birgit's story, p.87, Eric's story, p.120, Susanne's story, p.174.

54، Toronto's Cultural Life, Ah Me!" Broadfoot, pp.84-5; Helma's observations echo Grossman's observations of her new city: "In our eyes Winnipeg looked like a big village." Grossman, p. 86.
} 
No theatre, or museum, one or two movie theatres. In our opinion the Canadians are, aside from the TV, space heater or furnace, and washing machine, 50 years behind. For their entertainment they rely on the TV. ${ }^{55}$

In hindsight, Helma recognizes the European bias which she and her husband brought to Canada. In a letter home, she admitted that even had cultural exhibits existed, the family could not have afforded them, which likely reinforced their status as immigrants. Still, it was the "little things" such as "no table cloths in the restaurants," that left a big impression and called for a period of adjustment before they could accept Canadian culture-or lack thereof. $^{56}$

The excessive materialism that the Krolls found in Ottawa conflicted with their own very basic standard of living. Canadian immigrants entered a "place where people talked about money all the time." ${ }^{.57} 1950$ 's North America saw consumerism reach an all time high; though this world was exciting, it also made adaptation difficult for those who had arrived with virtually nothing. Nevertheless, the majority of postwar immigrants persevered, and made do. As new immigrants, the Hundreisers could not afford many of the "nice features" such as a furnace, contained in other Canadian homes; their house was "simple," and based upon the precept that "comfort [would] come later. ${ }^{58}$ The Hundreisers possessed a 'postwar pioneer spirit' commonly found in German immigrants, who as a group, could boast of an above average rate of entrepreneurism. ${ }^{59}$ Hubert Hundreiser worked full time outside the home and in his 'spare' time, he and his wife

\footnotetext{
${ }^{55}$ Helma Kroll to Richard and Elfriede Kroll. October 25, 1954. Book 2 p.5.

${ }^{56}$ Interview with Helma Kroll, June 20, 2005. p.20

57 "Money to be Made," Bruce, p.158.

${ }^{58}$ Helma Kroll to Eleonore Scholz and Richard and Elfriede Kroll. October 16, 1954. Book 2 p.3.

${ }^{59}$ Dr. Gottlieb Leibbrandt, Little Paradise: The Saga of German Canadians of Waterloo County, Ontario 1800-1975 (Kitchener: Allprint, 1980), p.301; Between 1950 and 1966, though Germans comprised 13\% of Canada's immigrants, they composed 19\% of newcomer entrepreneurs. Gerhard Bassler. "Germans," Encyclopedia of Canada's Peoples. Paul Robert Magocsi, editor. (Toronto: Published for the Multicultural History Society of Ontario by the University of Toronto Press, 1999), 600.
} 
raised and sold canaries, chickens and turkeys, a business which they hoped would soon become the family's mainstay. Helma and Reinhard were in a fortunate position given that they had shelter and therefore did not have to panic in the search for stable employment. Nonetheless, the Krolls desired independence, and they also aspired to start some type of business. ${ }^{60}$ Both ambitions required their own home; therefore, the Krolls would have to amass capital before either hope could be realized.

The lot of postwar immigrants with regards to employment was not an easy one, particularly in the early fifties. Though the Canadian economy had an abundance of work, opportunities for immigrants were generally limited to unskilled jobs. Discrimination, limited English ability, and exclusion from professional associations combined to put immigrants at a severe disadvantage compared to Canadian workers. ${ }^{61}$ They were seldom able to apply their professional training; in a crowd of Canadian immigrants, a DP translator recognized that

There were men who had been doctors, lawyers, accountants, engineers, men of quality any country would have been happy to have. Men who had a purpose in life, a sense of achievement, a large measure of pride and would have contributed a great deal to Canada, but they were being shut out [from their profession]. ${ }^{62}$

Many immigrants had been told that (skilled) work was bountiful in Canada. ${ }^{63}$ Reinhard had similarly been given the impression that "it would be easy for him to get work in forestry." However, after a few months in Canada, he realized that "all [his] hopes to get a job in [his] line of work [were] zero before [he became] a Canadian citizen;" the only private positions available were up north, and "for a man with a wife and three children

\footnotetext{
${ }^{60}$ Reinhard Kroll to Richard and Elfriede Kroll. December 18, 1954. Book 2 p.12.

${ }^{61}$ Danys, pp. 252-255.

62 "Canada Wanted Labourers, Not Professionals" in Broadfoot, pp.176-7.

${ }^{63}$ For example, see "We Had our Pride... But we had nothing" Broadfoot, pp.179-180.
} 
that wasn't very practical." ${ }^{\prime 64}$ In the Ottawa area, he found that at the few interviews he was granted, the ultimate response was 'no'. "It [was] either 'not a Canadian citizen'; first the Canadians considered, or 'How long will you stay with your background?"65

Just as Reinhard had to adjust to low employment expectations, Helma also had to deviate from her traditional role in East Germany. Helma had pursued 'outside' work at the refugee camp, but with Reinhard's employment expectations for Canada, it is likely that the couple did not foresee the need for Helma to join the workforce. Canada, like Germany, in the postwar period emphasized a return to the traditional, nuclear family. ${ }^{66}$ However, despite Canadian society's postwar push to return to the 'traditional life' with set and defined gender roles, this ideal was unattainable for most working class (and immigrant) families. ${ }^{67}$ The Canadian press viewed a wife's work as an attempt to purchase 'luxuries'; rarely did it acknowledge the fact that many families could not function without a wife's working wage. ${ }^{68}$ This was particularly true for the immigrant family, especially when the husband's search for stable and reliable employment was often made in vain. ${ }^{69}$ There would be times when Helma became the primary breadwinner of the family, making the Canadian government's assumption during the

\footnotetext{
${ }^{64}$ Reinhard Helma Kroll to Richard and Elfriede Kroll. December 18, 1954. Book 2 p. 12; Interview with Beate Myhill, August 9, 2005 p. 1.

${ }^{65}$ Helma Kroll to Eleonore Scholz and Richard and Elfriede Kroll. May 1, 1955. Book 2 p. 27.

${ }^{66}$ See Elizabeth D. Heineman. What Difference Does a Husband Make? Women and Marital Status in Nazi and Postwar Germany. (Berkeley: University of California Press, 1999). and Ute Frevert. Women in German History From Bourgeois Emancipation to Sexual Liberation. Translated by Stuart McKinnonEvans in association with Terry Bond and Barbara Norden. (New York: St. Martin's Press, 1986), p. 175

${ }^{67}$ Veronica Strong-Boag, "Home Dreams: Women and the Suburban Experiment in Canada, 1945-60," Canadian Historical Review 72, no.4 (1991): 471-504; and Veronica Strong-Boag, "Canada's Wageearning Wives and the Construction of the Middle Class, 1945-1960," Journal of Canadian Studies 29, no.3 (1994): 5-25; Franca Iacovetta. "Remaking Their Lives Women Immigrants, Survivors and Refugees," $A$ Diversity of Women: Ontario, 1945-1980. ed. Joy Parr. (Toronto: University of Toronto, 1995), 135-167. $25 \%$ of Canadian women were working in 1951. Alison Prentice, Paula Bourne, Gail Cuthbert Brandt, Beth Light, Wendy Mitchinson, and Naomi Black, Canadian Women: A History (Toronto 1988) table A.14, 422 as cited by Doug Owram, Born at the Right Time: A History of the Baby-Boom Generation. (Toronto:

University of Toronto Press, 1996.), p.29.

${ }^{68}$ Strong-Boag, Journal of Canadian Studies, 9-10.

${ }^{69}$ Iacovetta, Such hardworking people, pp. 90, 92, 102.
} 
immigration process - that she was unlikely to be a substantial contributor to the Canadian economy - all the more ironic. ${ }^{70}$ Participation in the formal economy may have placed additional burdens upon immigrant women, but it also seems to have entitled them to a greater say in family finances, household furnishings, food, leisure activities, and the like. ${ }^{71}$ While it is difficult to come to conclusive findings regarding changing gender roles through immigration, the spirit of financial cooperation brought about by necessity, seems to have altered to a degree the manner in which a 'traditional' European marriage such as the Krolls' operated. ${ }^{72}$

Reinhard and Helma took whatever work they could, knowing that 'every bit' would help them meet their goals. ${ }^{73}$ Nevertheless, unskilled employment such as domestic service, agricultural labour, lumber and mining could be demeaning work to immigrants who had been well qualified professionals at 'home,' or whose previous status had never required them to perform paid work. ${ }^{74}$ It was a type of psychological shock, in which they experienced both loss of status and often, a loss of identity. ${ }^{75}$ Some male immigrants found the change hard to take; one immigrant, who worked as a waitress, recounted her husband's aversion to taking such 'low' work:

\footnotetext{
${ }^{70}$ Monica Boyd, "The Status of Immigrant Women in Canada," Canadian Review of Sociology and Anthropology. 12 (1975): 407.

${ }^{71}$ In particular, Iacovetta cites a 1970 survey of sixty immigrant Polish families in Toronto. Iacovetta, $A$ Diversity of Women: Ontario,.151. She refers to Radecki with Heydenkorn, (Henri Radecki with Benedykt Heydenkorn. A Member of a Distinguished Family: The Polish Group in Canada.(Toronto: McClelland and Stewart; Ottawa: Multiculturalism Program, Dept. of the Secretary of State of Canada, Publishing Centre, Supply and Services Canada, 1976), pp. 133-7; and Iacovetta, Such Hardworking People, chapter 4, to support her conclusions. lacovetta, A Diversity of Women,151.

${ }^{72}$ Iacovetta, A Diversity of Women, 151.

${ }^{73}$ Helma Kroll to Eleonore Scholz and Richard and Elfriede Kroll. January 13, 1955. Book 2 p. 17.

${ }^{74}$ Freund, Alexander and Laura Quilici "Exploring Myths in Women's Narratives: Italian and German Immigration Women in Vancouver, 1947-1961,'BC Studies, nos. 105-6 (Spring/Summer 1995): 165-6.

${ }^{75}$ Danys, pp. 136,145; Henri Redecki with Benedykt Heydenkorn, A Member of a Distinguished Family: The Polish Group in Canada. (Toronto: McClelland and Stewart; Ottawa: Multiculturalism Program, Dept. of the Secretary of State of Canada, Publishing Centre, Supply and Services Canada, 1976), 53.
} 
There was a job as dishwasher came up at the café, and I suggested he take it. Oh no, oh no. God, God no! He was in the engineering trade, as he called it...I said he could do some engineering on the dishes but he said he was waiting for letters to come back from his applications. ${ }^{76}$

His solution was to return to the 'Old country.' However, like many other immigrantsGermans included - the Krolls were willing to settle for what employment they could find. ${ }^{77}$ For Reinhard, this meant work much below that of his former academic and professional station. ${ }^{78}$ Within his first two months in Canada, Reinhard had done different 'odd jobs' for varying terms: construction, beekeeping and the like. Even when ill, Reinhard did not take time 'off,' instead "he looked after all drafty corners, repaired what was within his limits and collected wood for the oven;" though such work did not pay, it at least was a contribution to the Hundreisers' home. ${ }^{79}$ This lack of stable (even if low paid) work made for a very precarious financial position; the presence of even a brief illness such as a cold, could spell financial ruin. Hence, at no point was Helma's employment even a question; it was a necessity.

Helma had brought her knitting machine from Germany with the hopes of bringing in a solid income in Canada; however, though she completed knitting orders for friends and neighbours, the earnings were far from adequate. Essentially, with regards to social status, Helma experienced "a role reversal. In East Germany, she had women who helped her in the household, and then when she came [to Canada] she became the

\footnotetext{
76 "Slinging Hash and Having Fun!" Broadfoot, pp. 152-3.

${ }^{77}$ See "We Cried Ourselves to sleep," Broadfoot, pp.180-1; and "On the Flimsiest Promise," Bruce, p.138.

78 This was typical of German immigrants. Ruth Gumpp, "Ethnicity and Assimilation. German Postwar Immigrants in Vancouver, 1945-1970." PhD thesis. (Vancouver: University of British Columbia, 1989), p.73. Richmond and Kalbach (Anthony H. Richmond and Warren E. Kalbach assisted by Ravi B.P. Verma. Factors in the Adjustment of Immigrants and their Descendants. (Ottawa: Minister of Supply and Services, under the authority of the President of the Treasury Board, Stastics Canada, 1980), p.52 as cited by Gumpp, p.81. [p.53 Richmond and Kalbach do not cite Germans in particular, they speak in general terms, but specifically those "most recently arrived immigrants."]; also see Allen, pp.20-21.

${ }^{79}$ Helma Kroll to Eleonore Scholz and her mother, Helene Schmitt. December 13, 1954. Book 2 p.10.
} 
helper." ${ }^{, 80}$ In Canada, Helma would follow the lead of many other German women, and work as a 'domestic.' The church was a helpful instrument for Helma, and assisted her to make contacts with those who required housecleaners. Another female German immigrant, in a similar situation to Helma, wrote,

In Germany, we'd had a comfortable life, and my friends wrote to me, 'How can you work as a maid, and live in a cellar, when you're a doctor's wife?' But it was all I could do, with such a limited command of the language. ${ }^{81}$

This 'downward' transition would undoubtedly have been a difficult experience for these women. However, for Helma-who had worked before meeting Reinhard and had experienced life in the refugee camp-such work was a necessity. Seemingly, any pretence otherwise had been lost throughout the refugee process. It is possible that Helma accepted her work more readily than her husband, given their difference in class background. ${ }^{82}$ Nevertheless, as an immigrant (particularly non-English speaking), Helma was vulnerable, and it is likely that she was knowingly taken advantage of. Given her family's financial insecurity, she depended upon housecleaning work; hence, despite not receiving a promised raise, she remained silent, writing that "it is steady work, so I had better keep my mouth shut." ${ }^{83}$ In retrospect, she states simply: "I was a cleaning lady, and yes, you do it. This was money that came in. Fifty cents an hour, but it was money which came in." ${ }^{84}$ Here, Alexander Freund's study regarding the memory of German domestics provides some insight. 25,000 of the over 100,000 German women who immigrated to

\footnotetext{
${ }^{80}$ Interview with Beate Myhill, August 9, 2005 p. 7.

81 "On the Flimsiest Promise," Bruce, p. 143.

${ }^{82}$ Helma is known to say that had it not been for the war, she and Reinhard would never have been allowed to marry. Email from Beata Myhill, March 24, 2006.

${ }^{83}$ Helma Kroll to Eleonore Scholz and Richard and Elfriede Kroll. December 27, 1954. Book 2 p. 14.

${ }^{84}$ Interview with Helma Kroll, August 9, 2005 p. 2.
} 
Canada during the $1950 \mathrm{~s}$, came under the auspice of domestic service. ${ }^{85}$ In light of their many trials, Freund found that in order to maintain a consistency between one's "selfconcepts and the almost diametrically opposed conditions of their lived experiences," many of these women "strained to insert domestic service into their image of successful immigrants without abandoning this image." she received as a domestic, she chooses to focus on the positives of this experience, using it as "a 'stepping stone; on [her and her family's] path to successful immigration." Helma's work was a necessity for the family, particularly when Reinhard was ill, had trouble with the motorbike, or was unable to find stable work. By the end of November 1955, Helma had three regular cleaning jobs, and continued to complete knitting orders and perform regular household duties.

During times when Reinhard did not have paid employment, he wrote "with her steady cleaning jobs Helma is for the moment, our money-maker. She is keeping us, together with some casual labour from my side, above water., ${ }^{, 88}$ For many men, this role reversal would have indicated a loss of prestige and caused some embarrassment, or a blow to their pride. ${ }^{89}$ This was the case for both Canadian and immigrant men alike. Contemporary psychologists and the press agreed that in order for men to maintain their critical sense of masculine identity, they had to be the wage earner-competition with his wife, as a worker, was detrimental to his sense of self, and therefore, the health of the

\footnotetext{
${ }^{85}$ Department of Citizenship and Immigration, Immigration Statistics 1950-1961 (Ottawa, 1951-1962) as cited by Alexander Freund, "Immigrants' Identities: The Narratives of a German-Canadian Migration," $A$ Chorus of Different Voices: German-Canadian Identities. Angelika E. Sauer and Matthias Zimmer, eds. (New York: Peter Lang, 1998), 189.

${ }^{86}$ Also see the brief account "No Protection for Domestics," Bruce, p. 134; Freund, A Chorus of Different Voices: German-Canadian Identities, 201.

${ }^{87}$ Freund, A Chorus of Different Voices: German-Canadian Identities, 201.

${ }^{88}$ Reinhard Kroll to Eleonore Scholz and Richard and Elfriede Kroll. December 27, 1954. Book 2 p.13.

${ }^{89}$ See Iacovetta, Gender Conflicts: New Essays in Women's History, .294; Such Hardworking People, p.74. Iacovetta points out however that most men accepted women's work as a necessity towards survival.
} 
family. ${ }^{90}$ In relation to Italian immigrants, Franca Iacovetta states that "Many men defined themselves first and foremost in familial terms... ${ }^{91}$ Once in [Canada], the capacity to bring home the 'real' wages - the family's highest and most secure wagescontinued to be a source of male pride. ${ }^{.92}$ Men had to reconcile the fact that their wives worked; for Italians, this was often accomplished by comparing North American work to the unofficial (farm) labour that their wives had traditionally performed in Italy. Male immigrants recognized that their wives' wages were crucial to the family economy; however, what was often a further blow to their pride was the type of work which their wives performed. As one Italian immigrant recalled "I didn't come to this country so my wife could be the maid and make pennies to pick up the dirty clothes for some family. I didn't want that." ${ }^{, 93}$ Reinhard does not express such a sentiment - with regards to either his own inability to support the family, or the 'demeaning' type of work which Helma performed; however, even if Helma's work was a blow to his pride, it is unlikely that this would be articulated in his letters-which his wife often wrote (or at least reviewed) and his family read. As will be discussed further, it is likely that the career expectations of Reinhard's family put pressure on their son, compounding any feelings of inadequacies which he might have had. Even when Reinhard found full-time work and after Helma had a baby in Canada, Helma continued to perform 'double duty,' working mainly through the informal economy while carrying out her standard 'motherly duties.' Again, this experience is consistent with that of Italian immigrant women: Helma's traditional place

\footnotetext{
${ }^{90}$ Strong-Boag, Journal of Canadian Studies, 12.

${ }^{91}$ lacovetta, Such Hardworking People, p.69.

${ }_{92}$ Iacovetta, Such Hardworking People, pp. 73-4.

${ }^{93}$ Personal interview, as cited in Iacovetta, Such Hardworking People, p. 74.
} 
in the home as primary caregiver, housekeeper, cook, and housekeeper, was preserved; nonetheless, her financial contribution was also relied upon. ${ }^{94}$

Like the Hundriesers, Helma and Reinhard sacrificed the present in exchange for their hopes of the future. Their letters abound with dreams of coming stability, when things would be 'better' for both themselves and their children. They diligently performed menial work, but as in the refugee camps, their hope propelled them forward. Eight weeks after their arrival, the Krolls found a house to rent, and "despite [their] very insecure financial situation" decided to leave the Hundreisers. ${ }^{95}$

The meaning of home is complex. According to Macgregor Wise, it

can be a collection of objects, furniture, and so on that one carries with one from move to move. Home is the feeling that comes when the final objects are unpacked and arranged and the space seems complete (or even when one stares at unpacked boxes imagining). The markers of home, however, are not simply inanimate objects (a place with stuff), but the presence, habits, and effects of spouses, children, parents, and companions. ${ }^{96}$

Despite the varied definition, it is Wise's statement that "Homes, we feel, are ours," which best fits the Krolls' relationship to their place in Manotick. ${ }^{97}$ For the first time in many years, they had their own home, together. For $\$ 35$ each month, they rented what Reinhard called "a very small house," but what in hindsight Helma labels "a garage."98 Beate remembers

Where the living room was, there were the double shed doors, garage doors, and the snow came underneath in the winter. There was no running water. My mother went up to the house of the neighbour's and brought pails of water to cook and clean. ${ }^{99}$

\footnotetext{
94 Iacovetta, Such Hardworking People, p.74.

${ }^{95}$ Reinhard Kroll to Eleonore Scholz and Richard and Elfriede Kroll December 27, 1954. Book 2 p. 12.

${ }^{96}$ J. Macgregor Wise, "Home: Territory and Identity," Cultural Studies 14, no.2 (2000):299.

97 J. Macgregor Wise, Cultural Studies, 299.

98 Interview with Helma Kroll, June 20, 2005. p. 16.

${ }^{99}$ Interview with Beate Myhill, June 20, 2005. p.16.
} 
Despite its primitive nature - the home had an outhouse, and the kitchen sink was water buckets and a bench — the Krolls celebrated their new found independence. ${ }^{100}$ Helma initially remembers it as "the biggest event... this was togetherness...the first time after two years, alone. It was wonderful." "101 Similarly, Reinhard wrote "We are happy now to build our own beginning."102 The Krolls covered the house's flaws "with a blanket of love" and plans for the future: they furnished their 'garage' with furniture borrowed from their landlords — described by Helma as 'big' and 'ugly'--supplemented by Reinhard's self-built furnishings made of donated wood. ${ }^{103}$ Moreover, they displayed art and decorations which they had brought with them from overseas, a collection which would amass as packages from Reinhard's artistic family continued to arrive. In relation to North American immigrants in the 1920s, Elizabeth Ewen has noted that such strategic adornment was common in immigrant homes:

Decorations transformed ugly walls into ornamental collages, with calendars depicting natural scenes, pictures of fruit, fish, and forests, all a way of keeping in touch with a remembered past: immigrant families created their parlors as shrines to a family culture. ${ }^{104}$

With photos, basic necessities from overseas, and reminiscences of their 'past' lives, the Krolls finally had their own home. For the first time in years, they could live in peace and solitude as "a family again," with some sense of certainty of where they were, and where they were going. ${ }^{105}$

\footnotetext{
${ }^{100}$ Reinhard Kroll to Eleonore Scholz and Richard and Elfriede Kroll Book 2 p.13.

${ }^{101}$ Interview with Helma Kroll, June 20, 2005. p. 16.

${ }^{102}$ Reinhard Kroll to Eleonore Scholz and Richard and Elfriede Kroll. December 27, 1954. Book 2 p. 13.

${ }^{103}$ Reinhard Kroll to Eleonore Scholz and Richard and Elfriede Kroll. January 5, 1955. Book 2 p.15; Interview with Helma Kroll, August 9, 2005 p. 9.

${ }^{104}$ Elizabeth Ewen. Immigrant Women in the Land of Dollars: Life and Culture on the Lower East Side, 1890-1920. (New York: Monthly Review Press, 1985), p. 158.

${ }^{105}$ Interview with Helma Kroll, August 9, 2005 pp. 9-10.
} 
The Krolls' new house was in Manotick. Though they had thought "of moving to Ottawa, to be closer to daycare and because hunting for a job might be easier," the Krolls wrote that they "would miss the Hundriesers and the village is better for our children and very good to all of us. We are just starting to feel at home here. Probably Ottawa would be better in some things, but we are staying here right now." 106 The Hundreisers were an important lifeline to the Krolls, and they wished to stay close to them. The Krolls' social circle also included several other German families (one in Manotick, the others within the National Capital District) with whom they visited, drank coffee, played cards, and most importantly, exchanged words of support, encouragement, and experience. ${ }^{107}$ Such informal networks were vital to the Krolls, particularly because they generally did not associate with the German-Canadian community at large. Postwar German-Canadians rarely settled in clusters, and accordingly, the German-Canadian community in Ottawa was widely dispersed. ${ }^{108}$ Between 1951 and 1961 , the German-Canadian composition of the Ottawa City population rose from 1.9 to $3.5 \% .{ }^{109}$ Though a 'community' of sorts existed, it was divided along national and religious lines, and was compounded by the fact that many did not want to be labeled 'German." ${ }^{110}$ Moreover, Ottawa's German-Canadian

\footnotetext{
${ }^{106}$ Reinhard Kroll to Richard and Elfriede Kroll Book 2 p.11.

${ }^{107}$ Reinhard was a keen card player, and with one German family, the Granz's, Reinhard found a pair with whom he could play 'Skat,' "an old traditional card game most played by men." Helma Kroll to Eleonore Scholz and Richard and Elfriede Kroll. March 10, 1958. Book 2 p.100; Interview with Helma Kroll, June 20, 2005. p. 19.

${ }^{108}$ Gumpp, p.47. Gumpp compares the lack of German clustering to heavily concentrated Asian and Jewish neighbourhoods found in Vancouver; Walsh, p.34.

${ }^{109}$ Census of Canada, 1941-1981 as cited by Walsh, p.19. Here, 'German' refers to ethnicity.

${ }^{110}$ Walsh, p.23. See scholarship on Ukrainian-Canadian communities and their internal divisions. For example, Lubomyr Y. Luciuk, “'This Should Never Be Spoken or Quoted Publicly': Canada's Ukrainians and Their Encounter with the DPs" in Canada's Ukrainians: Negotiating an Identity. Edited by Stella Hryniuk \& Lubomyr Luciuk (Toronto: University of Toronto Press, 1991), 102-122; Ihor Stebelsky, "The Resettlement of Ukrainian Refugees in Canada After the Second World War" in Canada's Ukrainians: Negotiating an Identity. Edited by Stella Hryniuk \& Lubomyr Luciuk (Toronto: University of Toronto Press, 1991 pp.123-155.
} 
community was historically insignificant. ${ }^{111}$ Thus, when the Krolls arrived, no framework or 'ethnic enclave' existed in which German newcomers could socialize. ${ }^{112}$ The Krolls were aware of the existing German-Canadian associations (one of which came into existence the year following their immigration), but like many of their compatriots, were not active participants. ${ }^{113}$ Ruth Gumpp suggests that such low participation indicates that postwar German immigrants "often regarded ethnic structures as of little relevance for their successful settlement," especially because they assimilated quickly without them. ${ }^{114}$ Gumpp argues that due to the little discrimination German-Canadians encountered from the host society, they did not need ethnic organizations in the same way as other, more 'alien' ethnic groups. ${ }^{115}$ By contrast, using the records of the German Benevolent Society—created in 1955-John Walsh concludes that for new German immigrants, the importance of the German community and culture was overridden by more immediate needs such as employment, housing and the like, at least for the first few years. ${ }^{116}$ His argument seems best fitted to the Krolls' experience. They rationalized their distance from 'their community' in practical terms: they "never had the time. [They] would have had to go to Ottawa," and both Reinhard and Helma, even after the purchase of a passenger vehicle, were not particularly "car friendly." There was a German Lutheran church in downtown Ottawa, in which the Krolls wished to have their children confirmed

\footnotetext{
"11 Walsh, p.35.

112 Walsh, p.23.

${ }^{113}$ Here I am referring to the German Benevolent Society in Ottawa. A more longstanding organization was the Trans-Canada Alliance of German Canadians, founded in 1947, an umbrella group that aided the settlement of many post-war Germans, both Volksdeutsche and Reichsdeutche; Gumpp, p.160. Forchner's testimonies suggest that although German-Canadian association participation was generally low, participation in an ethnic church was common, Forchner, p.220. Churches offered a shared set of values, faith, and a common heritage. Wolfgang's story also offers a logical explanation for the lack of German club participation, similar to the Krolls, p.197. His parents were too occupied by their farm duties to attend club meetings regularly; however, they enjoyed celebrating Mardi Gras with a German club annually.

114 Gumpp, p. 160 .

115 Gumpp, p.162.

${ }^{116}$ Walsh, pp. 66, 70.
} 
for "a little bit [of] tradition" and "a link to the German community" (notably, not for 'religious reasons'), but, because this would have required the Krolls to drive the children into Ottawa on a weekly basis (which they could not do), the minister refused to confirm them. ${ }^{117}$ The Krolls' tie to the German community thus remained on an informal basis through several groups of friends. Its absence in the Krolls' daily lives concurs with Iacovetta's observation that most Canadian newcomers benefited from the presence of relatives, compatriots, and co-religionists who could help them or with whom they could share their problems...;" though ethnic organizations could be a source of support, informal networks were a more frequently used outlet. ${ }^{118}$

The Krolls' relationship with the Hundriesers remained paramount, and is illustrated by their frequent mention in written correspondence. Over the next few years, the Krolls socialized with them on a frequent basis; they shared meals, slept over in each others' homes, provided moral support in times of hardship, and even 'exchanged' their younger children for several weeks during the summer to allow each set of parents a brief 'holiday.' The Hundriesers offered a connection with the homeland, but could also relate first-hand to the Krolls' struggles to adapt to Canadian society.

However, the Krolls also found a great deal of support from their Canadian neighbours. Again, their experience reflects that of many others with respect to the lack of government intrusion; though government officials showed 'good will' towards them, they gave postwar immigrants very little aid in their settlement and subsequent

\footnotetext{
${ }^{117}$ Helma Kroll to Eleonore Scholz and Richard and Elfriede Kroll. July 23, 1957. Book 2 p.89; Interview with Helma Kroll, August 9, 2005 p. 8.

${ }^{118}$ Iacovetta, Gatekeepers. Chapter 2. In her study of Italian-Canadians, Iacovetta concludes that community groups were more important in the lives of newcomers later on, but for those who came during the early postwar period, informal contact was by far the most common. lacovetta, Such Hardworking People, pp.151-2.
} 
adjustment-either physical or emotional. ${ }^{119}$ For the most part, this task fell upon churches, voluntary agencies, ethnic organizations, and of course fellow immigrants. In Ottawa, churches were particularly important in the postwar decade, given the lack of reception agencies; however, because of the difficulty reaching Ottawa, the Krolls could not depend upon the (German) Lutheran church located there. ${ }^{120}$ Instead, the Krolls found an important source of initial support in Manotick's United Church.

An Immigration Branch film strip stated that

The church is the centre of a rich social life for the congregation: boys' and girls' groups, clubs for teenagers, women's auxiliaries, societies for business and professional people... all these make church life a family affair. The church provides a friendly meeting place, as well as a place of family worship. After the service comes time for small talk, and perhaps an invitation to Sunday dinner, or a drive in the country. ${ }^{121}$

Particularly for new immigrants such as the Krolls, the church was far from a mere place of worship. As one immigrant contended, "The United Church was a club, really, as much as a religious place. My parents were told, 'That's where you'll make your contacts, and get your business." ${ }^{\prime 122}$ The Krolls' letters suggest that they attended the church on a semiregular basis, particularly in the beginning. They found it odd that "the whole social life... [was] circled around the church;" nevertheless, they participated to a minimum degree, and found the people kind and helpful. ${ }^{123}$ References to God in several of the Krolls' letters indicate that although not devoted attendees, faith played a role in their

\footnotetext{
${ }^{119}$ Fritz Wieden, The Trans-Canada Alliance of German Canadians: A Study in Culture. (Windsor: Tolle Lege Enterprises, 1985), p.18. Ottawa in particular, did not have immediate-postwar, formal relief agencies. John C. Walsh, "Re-thinking Ethnic Boundaries: The Negotiation of German-Canadian Ethnic Identities in Ottawa, 1945-75." MA thesis. (Ottawa: University of Ottawa, 1996), p.16.

${ }^{120}$ The German Benevolent Society, which aided new German (ethnic or national), was not created until 1955. Walsh, pp. 36, 62.

${ }^{121}$ Immigration Branch film strip [which was part of an "active advertising campaign" started in Britain and northwest Europe, beginning in 1951 (Bruce p.63)] as cited by Bruce, p.79.

122 "Church was a club...," in Bruce, p.155.

${ }^{123}$ Helma Kroll to Richard and Elfriede Kroll. October 4, 1954. Book 2, p.6.
} 
lives—or at least they wanted their parents to believe so. The letters and oral testimony suggest that the church's value to the Krolls was not in relation to their spiritual health; rather, it welcomed them to their community, provided an opportunity to mix with Canadians, and assisted their search for employment.

Because the German-Canadian community was somewhat inaccessible to the Krolls, they were inadvertently forced to depend upon Canadians. In comparison to other ethnic groups, German-Canadians had an extremely high rate of 'acculturation,' and the Krolls socialized with "dyed in the wool, absolute Canadians." 124 In the eyes of many, German immigrants were "untroublesome Canadians;" they looked like native-born citizens, were quiet, unassuming hard workers, quickly integrated into the economy, and shared dominant Canadian values, including staunch anti-Communism. ${ }^{125}$ During the postwar years, Canadian citizens were encouraged by reception workers and those who worked with immigrants, to "take every opportunity to interact and engage with the New Canadians" in order to aid their social integration. ${ }^{126}$ In her oral testimony, Helma stresses that the Krolls were made to feel very welcome by Canadians. Contrary to the experience of many immigrants, she found that even in respect to class they "were absolutely accepted, as a person, not as a cleaner." ${ }^{\prime 27}$ In some respects, such a perspective may filter out negative aspects of past experience. Helma has a vested interest in portraying a strictly positive experience, for she is friends with many Canadians and she chose to remain here; if discrimination were experienced, she would have to reconcile it with her present-day Canadian identity. As Janis Wilton discovered in her study of Australian

\footnotetext{
${ }^{124}$ Interview with Beate Myhill, June 20, 2005. p.19.

${ }^{125}$ See Allen and Iacovetta, Gatekeepers, Chapter 1.

${ }^{126}$ Iacovetta, Gatekeepers, Chapter 2.

${ }^{127}$ Interview with Helma Kroll, June 20, 2005. p.19. Nonetheless, when the Krolls moved to Richmond, Helma wrote that it was "by far not as prosperous as Manotick; we are fitting in here better." Helma Kroll to Eleonore Scholz and Richard and Elfriede Kroll. July 5, 1958. Book 2 p.107.
} 
Chinese immigrants, elderly immigrants are often very reluctant to share their past experiences of racism, because of a cultural aversion to speaking badly of the past. ${ }^{128}$ In addition, Alistair Thomson points out that it is also befitting to reflect how the recognition of such a painful 'citizenship' process might affect one's current conception of self in relation to their adopted home. ${ }^{129}$ Nonetheless, the Krolls certainly experienced Canadian hospitality. Shortly after their first Canadian move-which coincided with the holiday season - the Krolls were surprised by neighbours, coworkers, and acquaintances who dropped by "with gifts and good wishes." less 'lean' than the one the Krolls had anticipated

Helma's lack of English was an initial setback in fitting into Canadian society. While Reinhard could speak "without difficulties with everyone," Helma could not, and when spoken to, would "give a friendly smile instead." 131 However, just as with her outside work, in this respect Helma felt like she had little choice; the implication being that in order to function in Canada - as a resident, but more importantly as a worker-she needed to speak English. In a letter to her mother, she writes "Mutti, you ask how I can do it? Well, you have to, if they can't change to your mother-tongue. It is surprising how many words you find - and just suddenly it works, not always satisfactory, but it works." ${ }^{132}$ Helma's attitude towards her lack of English is not self-deprecating, but optimistic and rather stoic. She considers herself lucky as compared to Mrs.

\footnotetext{
${ }^{128}$ Janis Wilton, "Chinese Whispers from South Wales," in History Today 47, no.11(1997): 45-51; as cited by Alistair Thomson "Moving Stories: Oral History and Migration Studies" Oral History 27, no.1 (Spring 1999), p.33.

${ }^{129}$ Judith Winternitz, "Telling the Migrant Experience; The Oral History Project of the Ethnic Affairs Commission of N.S.W.," Oral History Association of Australia Journal, no.4 (1984): 45 as cited by Thomson, p.33.

${ }^{130}$ Reinhard Kroll to Eleonore Scholz and Richard and Elfriede Kroll. December 27, 1954. Book 2 p.13.

${ }^{131}$ Helma Kroll to Richard and Elfriede Kroll. October 25, 1954. Book 2 p.6.

${ }^{132}$ Helma Kroll to Eleonore Scholz and her mother, Helene Schmitt. November 10, 1954. Book 2 p.8.
} 
Brettschneider, who did "not speak any English;" though Helma herself understood little initially, her sympathy lay with the other woman, for whom she states "it [was] difficult." ${ }^{\prime 33}$ It is telling that neither Helma's oral testimony nor her written correspondence relays the difficulty of operating in a foreign tongue; though fluent English was not a necessity for her daily work, it would have undoubtedly increased the stress of everyday activity, and exacerbated any sense of 'foreignness' she had from those around her.

The lack of a strong German community undoubtedly sharpened Helma's learning curve, for socializing with native Canadians was an effective teaching method. The youngest Kroll children rapidly learned English through their Canadian neighbourhood playmates, while Gerd quickly acquired language skills at school. Helma does not elucidate how she learned English; rather, it is a process which she seems to take for granted. Though it is probable that her children helped her learn English (as is the case with many immigrant women), she frames her English education in terms of her positive interactions with Canadians. ${ }^{134}$ This conforms to the testimony of another German immigrant, who found that "even if there were some mistakes, some misspellings, some mispronunciations, nobody minded. Not at all. They praised you for trying. They liked you more for it. They treated you better..."135 In some respects, the German refugees were a novelty in the small town of Manotick, and native Canadians were eager for contact, wanting to hear of Helma's experiences. ${ }^{136}$ In her oral testimony, Helma is very reluctant to paint a bad picture of Canadians with whom she had contact-even those

\footnotetext{
${ }^{133}$ Helma Kroll to Eleonore Scholz and Richard and Elfriede Kroll. October 4, 1954. Book 1 p.62.

${ }^{134}$ Forchner, p. 210 .

135 “Don't Speak German in This House," Broadfoot, pp.112-113.

${ }^{136}$ Interview with Helma Kroll and Beate Myhill, Jume 20, 2005. p.16.
} 
nosy ones, who she euphemistically refers to as "too helpful sometimes." 137 Despite the occasional 'intrusion,' Canadians' interest led to work opportunities for Helma, and her improved English skills allowed her to develop genuine friendships with Canadians. She and Reinhard were friendly with their Canadian neighbours and the parents of their children's playmates, and would exchange short visits. ${ }^{138}$ They received house calls from Reinhard's English colleagues and their families, which Helma found "pleasant."139 Nonetheless, a more thorough social integration was fleeting: it was a full two years until Helma mentioned attendance a Canadian party - an event which provided her the opportunity to dress up and wear "high heeled shoes for the first time in Canada."140

Reinhard recognized that the attainment of Canadian employment was in large part based upon nepotism; it was with the help of a friendly neighbour that he ultimately found his first stable job: a night cleaner in a department store. ${ }^{141}$ As Beate later recalled

It was a significant thing for my father who came from a very well-educated family and well-to-do family, very cultured, with a Master's Degree, to take a job cleaning toilets in a department store. But you do what you need to do, and I think that was the attitude. I think it was very demeaning for him. ${ }^{142}$

Reinhard's work was a struggle, in terms of both practicality and his pride. Between his sleeping schedule, Helma's work and transportation problems, the family was challenged. Annelotte Hundrieser helped look after the children, and between public transportation and hitchhiking, both Reinhard and Helma (Helma did not participate in the latter method) found their way to and from work. However, Reinhard's correspondence with his parents conveyed his discontent with his current employment. He maintained that he

${ }^{137}$ Interview with Helma Kroll, June 20, 2005 p.16.

${ }^{138}$ Interview with Helma Kroll, June 20, 2005. p.19.

${ }^{139}$ Helma Kroll to Eleonore Scholz. November 22, 1955 . Book 2 p.46.

${ }^{140}$ Helma Kroll to Eleonore Scholz and Richard and Elfriede Kroll. November 1, 1956.Book 2 p. 75.

${ }^{141}$ Reinhard Kroll to Richard and Elfriede Kroll. Decemer 18, 1954. Book 2 p.11.

${ }^{142}$ Interview with Beate Myhill, August 9, 2005 p. 5. 
would continue to look for work more suited to his skills, but rationalized why he engaged in work below his station, writing "with this money we should get through the winter." 143 Consistently, Helma and Reinhard kept an optimistic face throughout their correspondence. Even in times of hardship, when "Really everything [was] going wrong," they spun the truth and wrote "but maybe it has to be like this, so that later on we know how well we have it. --- It is good to have an answer for every mishap." ${ }^{\text {"44 }}$ Nevertheless, at times it is not clear whether the Krolls' optimism was inherent to their natural disposition, or if such an attitude was assumed to appease their parents or decrease their worry. ${ }^{145}$ The dynamic between Reinhard and his father in particular is important to identify, for there is a clear indication that Helma and Reinhard felt pressure to 'do better' in their new homeland. Mr. Kroll Sr. had high expectations of his son. Reinhard had clearly deviated from his career path; furthermore, not only did Reinhard hold a menial position, but he was also unable to support the family as the sole breadwinner-which probably clashed with the Kroll forester background. Even several years later when Reinhard and Helma had started their own side business and Reinhard had moved into a daytime job with more security, the pressure from Mr. Kroll Sr. was still apparent. Reinhard wrote "from Father's letter I have the feeling that he regrets that we did not make more out of our life yet. Father, we have to make one step after the other - we believe that we will give our children and ourselves a better life." ${ }^{\prime 16}$ The presence of $\mathrm{Mr}$. Kroll Sr. in his son's life supports Boss's notion that immigrant letters allowed parents to

\footnotetext{
${ }^{143}$ Reinhard Kroll to Eleonore Scholz and Richard and Elfriede Kroll. January 12, 1955. Book 2 p.16.

${ }^{144}$ Helma Kroll to Eleonore Scholz and Richard and Elfriede Kroll. April 3, 1957. Book 2 p.84.

${ }^{145}$ Hoerder, Dirk. Creating Societies: Immigrant Lives in Canada. (Montreal: McGill-Queen's Univerrsity Press, 1999), p. 18; Irish Immigrants in the Land of Canaan: Letters and Memoirs from Colonial and Revolutionary. America, 1675-1815. Kerby A Miller, Arnold Schrier, Bruce D Boling, David N Doyle, eds. + writers. (Oxford: Oxford University Press, 2003), p.9.

${ }^{146}$ Reinhard Kroll to Eleonore Scholz and Richard and Elfriede Kroll. October 20, 1957. Book 2 p.94.
} 
continue a form of parenting from overseas. ${ }^{147}$ In this context, the confidence displayed in the Krolls' letters can be read in two respects: to reassure the Krolls' parents of 'suitable' job prospects, or allay any fears or worries they might have had about their children. Again, hope for the future was also a tool which the Krolls used to deal with present disappointment: Reinhard and Helma repeatedly discuss a time in which it would be financially viable for their parents to come and stay for an extended visit; their letters flourish with such statements as "You see, we are trying hard and we are sure that next year will be much better," and "it can get only better." 148

The next few years were challenging for the Krolls, as they strove to make the transition from "onlooker" to active participant in their new homeland. ${ }^{149}$ Reinhard struggled to write applications while working full-time, and Helma toiled to type them out amidst her housecleaning work, knitting orders, and 'regular' household duties. Using an informal, extended German network, Reinhard, through a German friend, made contact with another German who hired him as a maintenance worker at the British American Banknote Company. Although Reinhard stressed to his parents that he had "no plans to stay there until retirement," he maintained that it was "another step in the right direction" with more money, plus eventually health insurance and a pension. ${ }^{150}$ As Reinhard wrote, "[It is] wonderful that we can depend on this steady income and we could settle here for our lifetime, but we want more, for us and our children."151 The Krolls had greater dreams, and wished to follow the path of the Hundriesers and many of their compatriots,

\footnotetext{
${ }^{147}$ Boss, Marriage and Family Review, 376.

${ }^{148}$ Helma Kroll to Eleonore Scholz and Richard and Elfriede Kroll. January 12, 1955. Book 2 p.17.

${ }^{149}$ Reinhard Kroll to Eleonore Scholz and Richard and Elfriede Kroll. November 28, 1954. Book 2 p.9.

${ }^{150}$ Helma Kroll to Eleonore Scholz and Richard and Elfriede Kroll. May 1, 1955. Book 2 p. 27.

${ }^{151}$ Reinhard Kroll to Eleonore Scholz and Richard and Elfriede Kroll. May 15, 1955. Book 2 p.31.
} 
as entrepreneurs. ${ }^{152}$ Reinhard's new job coincided with the Krolls' decision to both grow trees and sell seedlings, which they would import from overseas nurseries. Their plans became a central theme of their letters; not only because they consumed their time and financial resources, but probably in addition, they brought hopes of gaining approval from Reinhard's father. Evidently, the Krolls' relationship with their parents determined the content of the letters. In this case, the nursery project had economic possibility, and working with trees was also something that Reinhard and his father had in common, making it a comfortable subject about which to write. The business was intended to be on the sideline for some time, and both Reinhard and Helma would work for it in addition to their other duties. It was a financial risk given their lack of capital, but the Krolls survived, often barely, in large part due to the meager savings which Helma carefully managed. The spring and summer of 1955 saw the family spend a great deal of time in the fields frantically working: they destoned and plowed the fields, planted, and packed off orders of seedlings for hours on end. For Helma and even more so for Reinhard, this meant a working day that extended long after their 'outside' work was complete.

The Krolls' letters repeatedly reveal monetary stress. Finances are a traditional theme of immigrant letters, particularly when the immigrant is seeking financial support or deferring requests for aid. ${ }^{153}$ The Krolls frequently received gifts from their parents, but rarely were they in the form of money; though clothing was expensive (and therefore appreciated on several levels by the Krolls), much of the goods sent over had a more

\footnotetext{
152 Of postwar immigrants, German-Canadians were the most likely to seek self-employment. Gumpp, p.88.

153 Letter writers also bring up poor finances in order to dissuade would-be immigrants. From the letters, this seems quite contrary to their intention, as soon into their correspondence they encourage the grandmothers to visit. David Fitzpatrick, "'Oceans of Consolation' Letters and Irish Immigration to Australasia." In Visible Immigrants. Edited by Eric Richards, Richard Reid, David Fitzpatrick. (Canberra: Department of History and the Centre for Immigration and Multicultural Studies, Research School of Social Sciences, Australian National University), 74-5.
} 
sentimental value: food, art, pictures, newspapers and the like from Germany. Time and again, Helma stresses that it is the emotional connection which motivated correspondence on both sides. Money likely became a focus for the letters because it was a concrete subject to which both parties could relate. As a central source of anxiety in the Krolls' lives, it was a logical focus for their periodic 'updates' for the Krolls' parents; discussion of finances would likely be thought to interest the parents due to the security associated with material wealth, and the concern they held for their children and grandchildren.

In a poignant statement, Helma wrote to the grandparents "In Germany they told us, in America - Canada the dollars are lying on the street - - nobody told us how many times we would have to bend down for each one." 154 Evidently, the Krolls' expectations exceeded their financial reality. They scrimped and saved in an effort to move up the economic ladder; though they ensured "a special treat" such as cake, coffee, and a cigar on Sundays, "every expense [was] endlessly discussed." 155 The planting business was not only time consuming, but all their immediate profits for the year went to "custom, freight and tools." ${ }^{156}$ It was also strenuous, both physically and mentally; it required a great deal of physical labour, and was surrounded by uncertainty: nurseries unable to meet their requests, customer orders which could not be filled, seedlings which arrived dead or did not meet Canadian custom's standards, and of course, the farmer's arch nemesisunpredictable weather. The Krolls' initial financial struggles were aggravated not only by the planting business, but also by their desire to purchase a car with which Reinhard could

\footnotetext{
${ }^{154}$ Helma Kroll to Eleonore Scholz and Richard and Elfriede Kroll. Aug 11956 Book 2 p. 71.

${ }^{155}$ Reinhard Kroll to Eleonore Scholz and Richard and Elfriede Kroll. March 20, 1955. Book 2 p.22.

${ }^{156}$ Helma Kroll to Eleonore Scholz and Richard and Elfriede Kroll. No date (located between May 23, 1955 and June 23, 1955) Book 2 p.32.
} 
commute, and their wish for a larger property. These latter three goals were realized with care; it was an unexpected pregnancy which proved to be their greatest expense.

At the beginning of July, Helma wrote to the grandparents of her impending pregnancy—their "first "Canadian":

Now it is said---We were at first as shocked as you are reading it. Read it more often. You will get used to it....We parents might have it easier without this little one, but on the other hand it is high time, so that the age difference to the other children is not too big. ${ }^{157}$

This passage strongly hints at the added stress experienced by the Krolls, but again, Helma put a positive spin on the pregnancy. Although her letters one year later are more revealing as she recalls "how worried" she and Reinhard were about the new baby, that is the extent to which the Krolls' anxiety was disclosed. ${ }^{158}$ Even five decades later, Helma is reluctant to address the couples' anguish over the pregnancy (although this indeed might be any mother's typical response to a 'surprise' child, who nevertheless became an integral part of the family). ${ }^{159}$ However, Beate recognizes the discrepancy between both memory and letters, and the reaction which she witnessed as a child. She states "when my mother wrote about [the pregnancy] it sounded like 'Oh, this is such a happy event,"' in an effort to shield her grandparents from their worries; however, she recalls that there were "eight months of tears, crying every day." 160 It is significant that Helma does not volunteer this aspect of their experience; however, she does permit it to go on record, explaining that "it was too short after arrival. We had no foundation..."161 Ursula, born November 1955, was the Krolls' "most expensive 'purchase" up until that point, costing

\footnotetext{
${ }^{157}$ Helma Kroll to Eleonore Scholz and Richard and Elfriede Kroll. June 29, 1955. Book 2 p.35.

${ }^{158}$ Helma Kroll to Eleonore Scholz and Richard and Elfriede Kroll. February 8, 1956. Book 2 p.58.

${ }^{159}$ Interview with Helma Kroll, August 9, 2005 p. 13.

${ }^{160}$ Interview with Beate Myhill, August 9, 2005 p. 13.

${ }^{161}$ Interview with Helma Kroll, August 9, 2005 p. 14.
} 
them $\$ 67$ in hospital bills and $\$ 75$ for the doctor, more than "the other 'inventory' in [their] whole house." ${ }^{162}$ Because Reinhard had not been with the bank note company long enough, this bill came directly out of the Krolls' very limited cash flow. Though Helma recalls it was their "most valuable purchase," the expense was unexpected and aggravated the Krolls' economic strain. ${ }^{163}$

Helma's pregnancy overlapped with other important milestones in the Krolls' lives. Though their second year in Canada contained financial hardship and worry, it also saw the Krolls develop a more secure footing as new Canadians. Their farm business provided many challenges and pitfalls, but it also gave them a new sense of identity within the larger community. The tree farm became a topic of conversation with neighbours, who would pull the Krolls aside to ask how it was doing. ${ }^{164}$ The Krolls also developed more Canadian routines. In the fall of 1955, both Hartmuth and Beate began school, and the Krolls moved to a larger house on more property within Manotick. The birth of Ursula provided an additional opportunity for the Krolls to feel more 'a part of'; both a new neighbour and an undisclosed women's group introduced Helma to the "nice custom—a "shower," at which Helma received enough clothing to "nearly outfit triplets." ${ }^{165}$ Here, Helma once again confronted Canadian materialism, except in this case, she benefited. Shortly after their move Reinhard wrote, "Everything is slowly getting on the right track and with God's and the kind neighbours help we will make it." ${ }^{\prime 166}$ One can infer that Reinhard had indeed felt discouraged in the past, but perhaps at this point, has genuine confidence in the future. He too seemed to have found his footing; he enjoyed

\footnotetext{
${ }^{162}$ Helma Kroll to Eleonore Scholz and Richard and Elfriede Kroll. February 8, 1956. Book 2 p.58.

${ }^{163}$ Interview with Helma Kroll, August 9, 2005 p. 14.

${ }^{164}$ Helma Kroll to Eleonore Scholz and Richard and Elfriede Kroll. June 29, 1955. Book 2 p.35.

${ }^{165}$ Helma Kroll to Elfriede Kroll. September 15, 1955. Book 2 p.43; Helma Kroll to Richard and Elfriede Kroll. December 8, 1955. Book 2 p.48.

${ }^{166}$ Reinhard Kroll to Eleonore Scholz and her mother, Helene Schmitt. December 4, 1955. Book 2 p.48.
} 
his new work, was on good terms with his fellow workers (though he admittedly expressed some disapproval of the union's practices and the inefficiency it caused), and carpooled part-way to work with a coworker. ${ }^{167}$ The Krolls' life, at least from a bystander's perspective, looked increasingly 'Canadian.'

The family continued to operate on both a strict budget and time line. Ursula's birth caused Helma to give up her outside housekeeping jobs for a short time, placing an additional strain on the family's small income. Nevertheless, Helma remained busy at home. Writing shortly after Ursula's birth, she remarked upon her quick recovery: "I am recuperating much faster from this little lady than from all the other children, or is there a little 'you have to?"'168 On the surface, Helma's full-time return to home conformed to Canadian standards of being a 'good mother;' however, upon closer inspection, one can see that like many immigrant women, she continued to work. ${ }^{169}$ At home, Helma took part in the 'informal economy:' she provided childcare in her home for another child besides Ursula, continued to knit, worked in the field during the day (and often the evening), all in addition to her standard 'motherly duties.' ${ }^{170}$ Time was precious. As Helma wrote,

The mountain of ironing must wait, and the bag with clothes which needed some mending, gave up hope a long time ago that they will get some attention. Something will be always neglected, if we are more interested in earning some dollars. $^{171}$

A 'lazy day' caused by rain might be enjoyed by other family members, but for Helma it meant the rare opportunity to catch up with tasks and mend clothes. Besides this, she was

\footnotetext{
${ }^{167}$ Reinhard Kroll to Eleonore Scholz and Richard and Elfriede Kroll. May 15, 1955. Book 2 p. 30.

${ }^{168}$ Helma Kroll to Eleonore Scholz and her mother, Helene Schmitt. December 4, 1955.Book 2 p.47.

${ }^{169}$ Strong-Boag, Journal of Canadian Studies, 14.

${ }^{170}$ Iacovetta, A Diversity of Women: Ontario, 1945-1980, 155.

${ }^{171}$ Helma Kroll to Eleonore Scholz and Richard and Elfriede Kroll. May 11, 1955. Book 2 p. 28.
} 
the family typist, for both job applications and seedling orders, and like many immigrant women, functioned as the family's money manager or 'finance minister. ${ }^{172}$ These roles were performed at home; Helma did not have access to a vehicle, and even when the Krolls bought a car, it was years before she learned to drive. At home with the children, there is a sense that Helma felt isolated. Like other female immigrants, she socialized with women in the neighborhood-immigrant and otherwise. ${ }^{173}$ However, in a revealing quote, Helma refers to a visit by Hundrieser's sister: "I wish she would come more often, somebody from "outside." 174 Whereas Reinhard worked with other men and had access to a vehicle, Helma was located on a property in a small village, and was thus distant from much activity, thus fitting with Veronica Strong-Boag's comment that "modern suburban wives were tethered to their communities in ways that few husbands could match." ${ }^{175}$ Moreover, Helma's situation was exacerbated by the fact that she was isolated by language; her feelings appear to correspond with the testimony of German women (interviewed by Lewis) in Northern Forestry towns: their language skills and physical distance from others provoked a yearning for the company of female compatriots. ${ }^{176}$

Nonetheless, Reinhard also had little spare time with which to socialize. He too performed a 'double duty,' going from his official job, to the fields at home, where he worked during the evening and on weekends. He even babysat for neighbours and mowed

\footnotetext{
${ }^{172}$ Iacovetta A Diversity of Women: Ontario, 1945-1980, 90,150.Reinhard to "everyone we can think of and want to wish a Merry Christmas to," December 12, 1956. Book 2, p.78. Note, that this letter is directed for a wider readership; it is a sort of brief summary or snapshot of the Krolls' life at this point, specifically in relation to the holidays. It contains general good wishes to all who read the letter or will have it read to them. It is reminiscent of previous migrant letters from the $19^{\text {th }}$ century which were intended for a broad audience.

${ }^{173}$ Iacovetta, Such Hardworking People, p.91.

${ }^{174}$ Helma Kroll to Eleonore Scholz and Richard and Elfriede Kroll. August 28, 1956. Book 2 p. 72.

${ }^{175}$ Strong-Boag, Canadian Historical Review, 489.

${ }^{176}$ Lewis, Annals: German-Canadian Studies, 154-5.
} 
lawns, in an effort to accumulate more money. ${ }^{177}$ Although the children and the household duties fell primarily to Helma, Reinhard occasionally entered this domain. After Ursula was born, Reinhard could be found looking after their daughter when his wife was otherwise occupied. Helma wrote "He likes to do it and does it well;" he also occasionally cooked (his 'specialty' was "fried liver and potato salad"). ${ }^{178}$ However, for the most part, Reinhards's household duties were relegated to repairs on the home. Indeed, the Krolls seemed to adhere to the message conveyed by a government-sponsored immigration film: although it recognized that women took jobs, it further declared that "...today as ever, the home is still the most important part of a women's life."179 The type of gender roles which existed within the Kroll household are perhaps best illustrated by the shock they felt upon meeting the minister of the local church: "we were surprised what he could all do. He helped his wife in the kitchen, to bring the dishes out. Things like this were nearly impossible. He washed the car and he went shopping for his wife." ${ }^{180}$ Helma concedes that "this was not how [my] family worked."181 A description of her children's imitation-through-play supports this statement. Helma describes their second Christmas in a letter to the grandparents:

the two boys played with the train, driving Beate's dolls around, pretending they were the fathers. In the meantime under my supervision, Beate, with a flushed face, was very busy cooking lunch on her little oven, with lots of dishes, mine and hers. She boiled potatoes (on my stove) made fried potatoes, warmed vegetables, and later on made tea and cacao. The boys were satisfied and Beate noticed for the first time how voracious[sic] her relatives are. Later on she had to wash the dishes and I heard my little housewife moaning. Many figures of speech I heard from her which were

\footnotetext{
${ }^{177}$ Reinhard Kroll to Eleonore Scholz and Richard and Elfriede Kroll. May 15, 1955. Book 2 p. 30.

${ }^{178}$ Helma Kroll to Eleonore Scholz. January 17, 1956. Book 2 55; Helma Kroll to Eleonore Scholz and Richard and Elfriede Kroll. December 27, 1955. Book 2 p.52.

179 "Women at Home." Filmstrip produced by the National Film Board for the Department of Citizenship and Immigration, 1952 as cited by Bruce,p. 75 .

${ }^{180}$ Interview with Helma Kroll, June 20, 2005. p. 22.

${ }^{181}$ Interview with Helma Kroll, June 20, 2005. (in response to my question) p. 22.
} 
very 'familiar' to me, as she told Hartmuth to dry the dishes, which he did, he got praised and corrected from her. Oh, children are of their parents, same words, same intonation. - - Gerd excused himself, he had something to do in his room? ${ }^{182}$

Clearly, the 'woman' in this household—Beate as her mother-was in charge of the cooking and cleaning, though interestingly enough, she enlisted the help of her younger brother. However, at a 'convenient' time her older brother left the scene. Helma seems to question the validity of his disappearance: if it was an effort to escape household chores, or if he had a genuine matter to take care of. That this passage immediately follows Helma's comments regarding parents and children, her observation of Gerd indicates that perhaps this too is an observed behaviour within the Kroll household by the oldest male. ${ }^{183}$ Within the German culture, "The men didn't do things that the house wife could do. We were so surprised that the men took up the baby and changed the baby. This would have been impossible in Germany, at least in the family circle which I got married in." ${ }^{\prime 84}$ Despite the fact that Reinhard did look after the children in the refugee camp, it was a "disconnect from real life;" though perhaps 'softened' due to circumstances, Reinhard's role as a husband and father was likely more similar to that of the traditional German male than that of the 'housebroken' Canadian husband. ${ }^{185}$ However, the possibility also arises that the minister's behaviour was an aberration, for Canadian social norms during the 1950s were such that traditional gender roles were akin to those of Germany. ${ }^{186}$ Nonetheless, it is important that one judges the family operations according

\footnotetext{
${ }^{182}$ Helma Kroll to Eleonore Scholz and Richard and Elfriede Kroll. January 8, 1956. Book 2 pp.54-5.

${ }^{183}$ However, Helma also refers to an instance in which Gerd made lunch. Helma Kroll to Eleonore Scholz. March 10, 1957. Book 2 p.82.

${ }^{184}$ Interview with Helma Kroll, June 20, 2005. p. 22.

${ }^{185}$ Interview with Beate Myhill, June 20, 2005. p. 22.

${ }^{186}$ Several of Forchner's case studies exemplify these traditional gender norms. For example, see Petra's story p.49, Claudia's story, p.103, Eric's story, p.123.
} 
to the contemporary period. ${ }^{187}$ At no time in her correspondence or oral testimony does Helma express any dissatisfaction with her marriage; quite the opposite, she consistently conveys a strong sense of appreciation for her partner. Helma refers to her marriage as a "wonderful arrangement...if one is down, you can be sure the other partner is pulling him or her out of the misery." 188 Though household duties were bound to a degree by gender norms, this was an arrangement which appears to have caused no resentment from either Helma or Reinhard. Theirs was a marriage of cooperation; both partners were busy working at full tilt, in an effort to ameliorate their present circumstances.

An interesting aspect of the Krolls' household was the manner in which the family operated as a cohesive unit. The children contributed as best they could; at times, they even donated part of their meager allowance to one of the family's saving jars. ${ }^{189}$ Gerd also earned money independently through a paper route with which he could buy some of his clothing and more 'frivolous' purchases, such as a used radio which brought "all happiness." ${ }^{190}$ In addition, he also helped support the family unit; on several occasions when his parents lacked capital, he lent them his "hard earned money" to advertise the family tree business. ${ }^{191}$ Physically, labour was shared as well. At eight, Beate looked after Ursula while her mother was in the fields. ${ }^{192}$ Moreover, the children partook in the physical labour, particularly as they got older. One of Beate's most vivid memories is working for the family business:

\footnotetext{
${ }^{187}$ See for example Gail Grant, whose study regarding the life histories of elderly women concludes that women of previous generations had different expectations of happiness and marriage than 'modern' women. Gail Grant. "That Was a Woman's Satisfaction: The Significance of Life History for WomanCentred Research," Canadian Oral History Association, 11 (1991): 36.

${ }^{188}$ Helma Kroll to Eleonore Scholz and Richard and Elfriede Kroll. August, 1956. Book 2 p.71.

${ }^{189}$ Interview with Helma Kroll, June 20, 2005. p.18.

${ }^{190}$ Reinhard Kroll to Eleonore Scholz and Richard and Elfriede Kroll. July 7, 1955. Book 2 p.36; Reinhard Kroll to Eleonore Scholz and Richard and Elfriede Kroll. February 14, 1956. Book 2 p.59.

${ }_{191}$ Helma Kroll to "both families and friends." December 27, 1955. Book 2 p.51.

${ }^{192}$ Interview with Beate Myhill, August 9, 2005 p. 3.
} 
... [it] was thanksgiving weekend one year. It was raining, it was cold, it was miserable, and we had a contract for 50,000 seedlings - two year old Scotch Pine seedlings for CMCC that had to be dug up and counted and bundled because that would provide money for the municipal taxes that year.. It had to be done, and we worked there in the cold and the rain all weekend. My older brother and my father digging, and my mother and my younger brother and I, counting and bundling the seedlings, packing them. And pine, evergreens, if you get them, they poke your skin .... [and it] will get red. It will cause swelling, a rash. We were all of course, from all this handling in the cold, in the mud, in the wet, we did all that work; it was pretty damn miserable. But it was for me a tremendous sense of accomplishment, and feeling like a necessary part of the family unit, it was empowering...the point was that we were needed in the family unit, for the family to survive...It's very difficult for me to convince my kids when they were growing up 'if you don't empty the dishwasher, the family will fall apart.' And that's what we gained out of that. I think that was a part of [how] our parents empowered us. All of the family decisions were made as a family. I mean, at least we felt that we were part of the decision-making process. Even though the decision was made, but we felt like we were included in the decision. ${ }^{193}$

This weekend likely occurred several years later, but nonetheless, it successfully illustrates how the Kroll family operated. This cooperative effort corresponds to the experience of other first generation immigrant families, who toiled together for the collective good. Beate's testimony is explicit in her recognition that it was with a sense of pride and ownership that as an older child, she contributed to her family's success, and felt like a useful and much-needed member of the family unit. Though like all children, the Krolls likely displayed periods of reluctance towards their chores and household duties, the overwhelming indication throughout the correspondence and oral testimony is that they were willing workers. As Helma noted, "I have the feeling all four children understand, each according to their own age, their parents' struggle and try to help in their way." 194 Seemingly, the children felt that they belonged to a greater whole, and as such, had a responsibility, and a vested interest to help facilitate their family's success.

\footnotetext{
${ }^{193}$ Interview with Beate Myhill, August 9, 2005 p. 4.

${ }^{194}$ Helma Kroll to Eleonore Scholz. May 16, 1956. Book 2 p. 67.
} 
Unfailingly, the Krolls maintained that their hard work and sacrifice was well worthwhile, in order to provide their children with a better future. This is consistent with other immigrants, who, even when dissatisfied with their own lot, took pride and satisfaction that their children flourished on Canadian soil. ${ }^{195}$ The children quickly performed well in school, and their progress became a central theme in the Krolls' letters. German culture traditionally attached a great deal of importance to education, thus its emphasis in the Kroll correspondence is logical. ${ }^{196}$ It must also be remembered that the lack of educational opportunity for the Kroll children had been an important factor in the Krolls' decision to leave the GDR. ${ }^{197}$ Furthermore, as foresters, Reinhard's family was particularly well-educated; report cards were therefore a straightforward barometer to show the children's progress in a context which their grandparents would understand and value. Gerd was thrown into public school immediately without significant language skills, but he soon caught up. At the end of his first year, Helma reported he had "all ' $A$ ' and 'B's'; he is fitting into his class." ${ }^{198}$ By the winter of his second year, "he won the school spelling-bee of the $6^{\text {th }}$ to $8^{\text {th }}$ school-year, which," Reinhard noted, "after one and a half years in Canada, without any English before arriving here, is very good. Now he has to represent his school in a match with the Ottawa schools. We are all very proud of his work." ${ }^{199}$ Beate and Hartmuth started school in their second Canadian fall. The Krolls' letters express general satisfaction with the education system. They evaluated teachers, approving of those who held their students to a high standard and enforced their expectations, and they chastised those who did not keep a close eye on their children or

\footnotetext{
${ }^{195}$ Of the German-Canadian women Lewis interviewed, 2/3 said that that their greatest personal gain was that their children grew up in Canada. Lewis, Annals: German-Canadian Studies, 156.

${ }^{196}$ Forchner, pp. 226-7.

${ }^{197}$ Interview with Helma Kroll, August 9, 2005 p. 18.

${ }^{198}$ Helma Kroll to Eleonore Scholz and Richard and Elfriede Kroll. May 1, 1955. Book 2 p.28.

${ }^{199}$ Reinhard Kroll to Eleonore Scholz and Richard and Elfriede Kroll. February 14, 1956. Book 2 p.59.
} 
keep the parents well-informed. ${ }^{200}$ Their remarks suggest a respect for authority figures, order and traditional boundaries, noted characteristics of German-Canadians, by North American observers. ${ }^{201}$ The Krolls expected all of their children to ultimately attend university, and their letters illustrate the esteem they placed upon formal schoolingwhich likely reaffirmed their own cultural values and those of their parents, providing a sense of continuity with the past, and reassurance for those who raised them. ${ }^{202}$

In all likelihood, the Krolls' integration into Canadian society and the 'Canadian way of life' was accelerated by their children. The need for neighbourhood playmates brought the Krolls into contact with Canadians, and their children's attendance at a Canadian public school put pressure upon the Krolls to conform. Gisela Forchner's study of postwar German-Canadian immigrant families suggests that assimilation occurs on a spectrum: on one end, it is spurred on by immigrant parents, on the other, parents reluctantly trail behind their children. ${ }^{203}$ Much of the Krolls' cultural change appears to have occurred through the initiative of Helma and Reinhard; nevertheless, in some respects the Kroll children also taught their parents how to be Canadian, a notion reinforced by the occasional incident of cultural conflict. ${ }^{204}$

Of postwar ethnic immigrant groups, German-Canadians had the fastest rate of language assimilation, and similarly, were known for their rapid integration into Canadian society and swift loss of 'German' culture. ${ }^{205}$ Such adjustment fit into the postwar

\footnotetext{
${ }^{200}$ See letter from Helma Kroll to Eleonore Scholz. December 10, 1955. Book 2 p.49.See letter from Helma Kroll to Eleonore Scholz and Richard and Elfriede Kroll. November 19, 1957. Book 2. pp.95-6.

${ }^{201}$ Forchner, p.12.

${ }^{202}$ Interview with Helma Kroll and Beate Myhill, August 9, 2005 (this portion was not recorded) p.6.

${ }^{203}$ Forchner, p. 208.

${ }^{204}$ Lewis, Annals: German-Canadian Studies, 155; Forchner, pp.209-210.

${ }^{205}$ By the 1960s, of all Canadian immigrants, German-Canadians had the highest proportion of English speakers. McLuaghlin, p.17. Beatrice Stadler has argued that language assimilation directly corresponds to cultural integration. Language Maintenance and Assimilation The Case of Selected German-Speaking
} 
Canadian ideal, for as Korineck has observed, "in an era in which immigrants were called new Canadians and multiculturalism was unheard of, the decision to emigrate to Canada meant integration."206 Linguistically, the Krolls picked up English quickly, particularly the young ones. Even Ursula, though Helma and Reinhard "talk[ed] to her in German.... answer[ed] in English, -fully bilingual." 207 In December 1955 (after only one year in Canada), Helma wrote to the grandparents that "the children recited their English Christmas poem and sang 'Stille Nacht' in German-but only partly-we slip into English very easily."208 The older children's regular utilization of English would have undoubtedly improved their parents' English as well. As one Russian immigrant attested, his father knew only formal English, and thus "he just loved all [his sons'] new little slang expressions" which they picked up on the playground and in school. ${ }^{209}$ Beate recalls that English was initially 'tolerated' in the home because both Helma and Reinhard wanted the children to assimilate into their classes at school; evidently this strategy worked, for after two years in Canada, English was the dominant language of the siblings. Nevertheless, German was still Helma's and Reinhard's: they understood it best and they wanted their children to retain it. The children were forced to write in German to their grandparents in order to maintain that relationship and retain their mother tongue. Moreover, the Krolls continued to speak German in the home; and, on a nightly basis,

\footnotetext{
Immigrants in Vancouver, Canada. (Vancouver: CAUTG, 1983), p. 2; Hartmut Froeschle "The History and Heritage of German Immigration to Canada," Canadiana Germanica-A Journal for German-Canadian Studies and News Bulletin of the German-Canadian Historical Association and the Historical Society of Mecklenburg Upper Canada Inc. Occasional Papers Beihefte. No. 3 (1982):12; also see Allen; Bassler, Encyclopedia of Canada's Peoples, p.610.

${ }^{206}$ Valerie J. Korinek, Roughing it in the Suburbs: Reading Chatelaine Magazine in the Fifties and Sixties. (Toronto: University of Toronto, 2000), pp. 285-286.

${ }^{207}$ Helma Kroll to Eleonore Scholz and Richard and Elfriede Kroll. September 7, 1957. Book 2 p.92.

${ }^{208}$ Helma Kroll to "both families and friends." December 27, 1955. Book 2 p. 52.

209 "Three Cheers for Miss Hudson," Broadfoot, pp.105-6.
} 
Reinhard read to the children from translated books, his favourite: Grey Wolf, in German. $^{210}$

Beate recalls that the "children losing their cultural background, becoming assimilated...was something that [her parents] were worried about."211 As Ewen has observed, this fear is not atypical: "Immigrant mothers feared the pull of the new life"particularly in relation to the effect that North American patterns of work and recreation would have on their children. ${ }^{212}$ Helma concurs that besides "having food for the next day... keeping her family together in a certain standard" was a central concern. ${ }^{213}$ Even so, though some German immigrant children noted that their families were stricter than their peers, it is interesting to note that Beate does not remember any large disparities between how she was raised in comparison to other Canadian children. ${ }^{214}$ The only differences Beate recalls are seemingly more 'minor,' those which relate to manner and etiquette. "There were higher expectations in what Canadian children were expected to do in terms of table manners and shaking hands and even the curtsey thing.... Boys were expected to bow their heads and girls were expected to curtsey and shake hands when you met somebody" and "look them in the eye.", "Right from the beginning, [the children] were taught to eat with a knife and fork."216 Other German immigrants have commented that Canadians were "too generous" with their children, and thus Canadian children were

\footnotetext{
${ }^{210}$ Email from Beate Myhill, March 4, 2006.

${ }^{211}$ Interview with Beate Myhill, August 9, 2005 p. 17.

${ }^{212}$ Ewen, p.208.

${ }^{213}$ Interview with Helma Kroll, August 9, 2005 p. 17.

${ }^{214}$ This is a very prevalent theme within the interviews. 10 of the 12 (adult) interviewees perceived their parents as strict. Forchner, p.206; Interview with Beate Myhill, August 9, 2005 p. 6.

${ }^{215}$ Interview with Helma Kroll and Beate Myhill, August 9, 2005 p. 6.

${ }^{216}$ Interview with Beate Myhill, August 9, 2005 p. 6.
} 
'out of line' by German standards. ${ }^{217}$ While Helma suggests that she and her husband might have been "a little bit tougher in the beginning," this evidently did not leave a marked impression upon her eldest daughter. ${ }^{218}$ Probably Helma and Reinhard also conformed more closely to Canadian standards of childrearing over time, a notion further supported by Beate's observation that in terms of who was the "most Canadianized," it would be her youngest sibling, Ursula, the 'first Canadian.' 219

Conflict did occur between the generations, especially regarding clothes. Clothes are an important indicator of identity and hence are often a controversial issue in immigrant families. As Ewen asserts, in the early twentieth century, "Clothing was a major arena of contention between mother and daughter. Immigrant mothers came from cultures where [dress] connoted class, status, and religious affiliation. ${ }^{220}$ Dress was a marker of difference; an early twentieth century text cautioned new American immigrants: "in the United States dress serves to conceal one's origins and relationships....Follow the Old World practice, and show who you are and where you come from and the result is that your children will not stay with you 'outside the gates. " 221 New immigrants, especially female adolescents, were particularly sensitive to dressing differently from their peers, and would often go great lengths to conform. ${ }^{222}$ As one postwar German immigrant testified, "When I was a teenager, a friend of the family

\footnotetext{
${ }^{217}$ Forchner. Though this is explicitly stated only once (see Petra's story, pp.74-5) it is implied throughout the interviews, particularly regarding the strictness of the German-Canadian parents.

${ }^{218}$ Interview with Helma Kroll, August 9, 2005 p. 6.

${ }^{219}$ Interview with Beate Myhill, August 9, 2005 p. 6.

${ }^{220}$ Ewen, p. 197.

${ }^{221}$ Sophinisba Breckenridge, New Homes for Old (New York, 1921), p.137 as cited by Ewen, p.197.

222 This is illustrated early in the $20^{\text {th }}$ century as well, particularly young women. Ewen, p.69; Michele Langfield and Pam Maclean, "But Pineapple I'm Still a Bit Wary of': Sensory Memories of Jewish Women Who Migrated to Australia As Children, 1938-9," Speaking to Immigrants: Oral Testimony and the History of Australian Migration. A. James Hammerton and Eric Richards, eds. (Canberra: History Program and Centre for Immigration and Multicultural Studies, Research School of Social Sciences, The Australian National University, 2002), 103.
} 
gave me this beautiful embroidered peasant blouse, and I refused to wear it. No one else at school wore things like that, and it made me feel German when I wanted so badly to be Canadian." ${ }^{223}$ Arguably, dress was even more important during the postwar era, when consumerism had reached a new high. Not surprisingly, clothing was an issue of contention in the Kroll home.

Apart from Helma's knitting business, references to clothing are fairly scarce in the Krolls' letters, particularly regarding this intergenerational battle. In part, this might be because of the time frame: such disagreements likely would have increased over time - beyond the scope of the letter collection - as the children became older and more self-conscious. Particularly in the early years of immigration, fashion would have presumably been a low priority for both Helma and Reinhard, the authors of the letters. Furthermore, their readers - practical-minded grandparents-was unlikely to find clothing a topic of pressing concern. Presumably, they wanted news of their grandchildren and their children's financial well-being; nonetheless, dress could also conceivably indicate the state of the family's finances. In addition, clothing was a straightforward way to highlight 'cultural' difference to the grandparents - especially the grandmothers. Helma initially remarked upon particular features of Canadian clothing: it was not (home)sewn like Germans,' and 'everyone male or female, youngsters to grandmothers," wore "heavy blue pants 'Blue Jeans.",224 In her letters, it is interesting to note that rarely does Helma criticize Canadian styles; in fact, she appreciated some of their features, for example, zippers and mending clothes with iron on patches. Nevertheless, we know from Beate's oral testimony that there were certain clothing styles

\footnotetext{
223 "Self-conscious about Identity," Bruce, p.159.

${ }^{224}$ Helma Kroll to Eleonore Scholz and Richard and Elfriede Kroll. October 16, 1954. Book 2 p.4.
} 
to which her parents objected; furthermore, in some passages, Helma's belief in the superiority of the 'German way' is explicit; for example, she asks Reinhard's mother to send socks, for the Canadian ones were "very thin." 225

Helma valued good quality clothing, especially because she was a clothing 'supplier,' taking knitting orders. Dress for Helma was a source of pride. She wrote "Right now my family looks still well dressed, even beside some rich Canadian." Helma compares her family's appearance to 'Canadians,' her point of reference. More importantly however, this excerpt shows that for Helma, clothing represented economic status. Particularly in the first few years, new clothing was a luxury; when needed, the family purchased used clothing for the children, including snow-suits which Helma repaired. ${ }^{227}$ Hartmuth wore hand-me-downs from Gerd, and Gerd even paid for his own winter boots with newspaper money. As the Krolls' finances improved, they were able to afford more. Two years after their arrival, Helma makes references to buying clothing through a catalogue. Yet, she frames her shopping habits in the context of money management: "I am not a good shopper in stores and we can't afford to buy more than is really necessary."228

Clothing was often written about under the guise of finances, or gifts for the children. Because of its expense, it often constituted a portion of birthday and Christmas gifts, events about which the Krolls wrote extensively. Through holiday letters and birthday synopses, new shirts, pants, and more 'frivolous' items such as 'a 'crinoline'-it

\footnotetext{
${ }^{225}$ Helma Kroll to Eleonore Scholz. August 31, 1956. Book 2, p.73.

${ }^{226}$ Helma Kroll to Eleonore Scholz and Richard and Elfriede Kroll. May 11, 1955. Book 2, p.28.

${ }^{227}$ Helma Kroll to Richard and Elfriede Kroll. December 14, 1955. Book 2 p.50.

${ }^{228}$ Helma Kroll to Richard and Elfriede Kroll. October 20, 1956. Book 2, p.75.
} 
was THE dream for [Beate]," found their way into the Krolls' correspondence. ${ }^{229}$ Moreover, clothing also demonstrated the passage of the time, and thus would be mentioned as the seasons changed, and Helma brought out the previous year's dress. In this respect, clothing also marked the children's growth; for instance, at the end of their third Canadian spring, Helma wrote "Beate and Hartmuth have grown a lot; we tried on the summer clothes. With Gerd it is even worse, he is now slipping into the more expensive teen sizes." ${ }^{230}$ Initially, much of the children's clothing was homemade, or it was used and underwent alterations. However, as time passed, the Krolls could afford to buy more. Until their third Christmas, they had "never had the chance to put aside money for special occasions;" but that year, Helma wrote

We were able to buy the children the needed pants, shoes for Hartmuth and Beate; she also got the skating skirt she was dreaming of and wool for a pullover... [Reinhard and I] both got wool socks, which were needed to stop the endless mending of the old ones. I got a paper cutout of a blouse, skirt and dress so that I can choose what I want and buy it for myself. Yes, we parents have to look a bit after our appearance - all our things are still from a long time ago in Germany. Our father has in the moment a hat with a hole in the front... and this with the good car he is driving! ${ }^{231}$

With increased access to money, the Krolls were able to participate more and more in a consumer society which identified dress and style as important. Nevertheless, the couple was resistant to some 'Canadian' ways. Beate recalls that as a child, Helma and Reinhard objected to blue jeans, shorts for men, and high-top running shoes in favour of lederhosen and "good leather footwear." 232 These latter items were commonplace in Germany; however, in Canada, they were markers of difference. To a self-conscious child or

\footnotetext{
${ }^{229}$ Helma and Reinhard Kroll to Eleonore Scholz and Richard and Elfriede Kroll. December 25, 1956. Book 2 p.79.

${ }^{230}$ Helma Kroll to Eleonore Scholz and Richard and Elfriede Kroll. April 11, 1957. Book 2 p.86.

${ }^{231}$ Helma Kroll to Eleonore Scholz and Richard and Elfriede Kroll. December 26, 1957. Book 2 p.97.

${ }^{232}$ Interview with Beate Myhill, June 20, 2005. p.17.
} 
teenager, they were likely to exacerbate any existing 'immigrant' insecurities; hence, for some time, the Krolls' adherence to German fashion was a source of contention in the family. Nevertheless, Beate concludes that her parents' attitude was a "typical immigrant mindset...if you come to a country and they do things differently, then at first that way can't be as good as the way it was done before. ${ }^{, 233}$ Clothing was one aspect of becoming Canadian, whether or not it was acknowledged as such. Towards Canadians' manners, habits, and mode of dress, though Reinhard and Helma "definitely had those kinds of cultural expectations, where it took a while" to conform, the implication is that their objections to many 'Canadian ways' diminished over time-a process which was undoubtedly aided by their children. ${ }^{234}$ Helma and Reinhard partook in Canadian activities, and they socialized with Canadian friends, suggesting that their disapproval of Canadian habits had limited impact upon their social activities.

Given their stringent budget, little of the Krolls' funds were directed towards leisure. However, those activities in which the Kroll children participated emphasize their Canadianization, and suggest that Helma and Reinhard's accepted and encouraged their children's participation in 'the Canadian culture.' During their first summer in Ottawa, the Krolls went to the Exhibition, an annual fair held in Ottawa. Though the venture cost Helma and Reinhard $\$ 10$, they concluded "it was one of those things which had to be done to keep peace in the house....The children [had been] talking about it for weeks and it would have been a disaster if we could not have gone." ${ }^{235}$ Likely, the Kroll children had heard about the fair from their Canadian friends, and they too wanted to join in.

\footnotetext{
${ }^{233}$ Interview with Helma Kroll, August 9, 2005. p.17.

${ }^{234}$ Interview with Helma Kroll, August 9, 2005. p.6.

${ }^{235}$ Reinhard Kroll (presumably, not signed) to Eleonore Scholz and Richard and Elfriede Kroll. August 23, 1955. Book 2 p.40.
} 
Helma and Reinhard acquiesced to their children's wish to partake in such an authentic 'Ottawa-ian' activity. Most of the Krolls' leisure activities did not cost money, but all had a genuine ring of 'Canadian' to them. Little time or money was set aside for leisure as a family unit particularly in the first few years; however, the children swam in the local river, went ice skating, biking, and even skiing (initially with borrowed equipment), often with local children from the neighbourhood. Hartmuth even joined the Cubs, a very North American organization (although admittedly reminiscent of Fascist children's organizations as well). Another important activity which emphasized the Kroll children's integration was their annual birthday parties, to which Canadian playmates were invited. Curiously, despite their prevalence in Canadian society, Helma views the children's birthday parties as one German tradition which the Krolls retained. ${ }^{236}$

Two important aspects of ethnicity which immigrants often maintain are holiday celebrations and food; this held true for many German-Canadians, including the Krolls. ${ }^{237}$ For German-Canadians, the celebration of Christmas was a particularly important cultural holiday. ${ }^{238}$ In place of electric lights, the Krolls' tree had wax candles; and even more discernibly, instead of gift-giving Christmas morning, they opened their gifts on Christmas Eve night-a practice not always appreciated by their Canadian neighbours, who, on the Krolls' first Canadian Christmas Eve, dropped by. ${ }^{239}$ The kind-hearted couple had brought a box of preserves, but the children were not impressed: unfamiliar with German customs, the couple stayed on to chat and enjoy a bottle of wine, while "the

\footnotetext{
${ }^{236}$ Interview with Helma Kroll, August 9, 2005 p. 10.

${ }^{237}$ Forchner, p. 231 . Also see Birgit's story, p.94, Eric's story, p.126.

${ }^{238}$ Walsh, p. 100.

${ }^{239}$ Interview with Beate Myhill, June 20, 2005. p.23.
} 
children were tired and they wanted their gifts!" ${ }^{240}$ The celebration of Christmas was a perceptible aspect of "Germanness" which tied Helma and Reinhard to their heritage, and kept their children in contact with their "cultural background;" nonetheless, the children were "very happy" when the family adopted a Canadian custom, and got two strings of electric Christmas lights with which to adorn their tree. ${ }^{241}$

Food has been identified as an important tool which new immigrants use to maintain a sense of self. ${ }^{242}$ The preparation and consumption of meals bestow immigrants with a sense of control in an environment where they have little. Moreover, food provides a link with family, culture, and heritage; thus, it can be used to recreate the feeling of 'home. ${ }^{243}$ In specific reference to German-Canadians, Gisela Forchner writes that in the ritual behaviour of eating ethnic food, "a multitude of the values and beliefs they grew up with, and which are now part of their identity, are expressed. In eating this way they maintain essential aspects of themselves, rehearsing them everyday;" it is one of "those everyday traditions at home which are not interfered with by society, in order to keep some constancy in one's self-understanding." 244 Forchner points out that this is generally an unconscious choice, about which a family might simply say "German food just tastes better."

\footnotetext{
${ }^{240}$ Interview with Helma Kroll, June 20, 2005. p. 23.

${ }^{241}$ Interview with Helma Kroll, August 9, 2005 p. 17; Helma book 2 52; Interview with Helma Kroll, June 20,2005 . p. 22 .

${ }^{242}$ Forchner 234; also see Donna Gabbaccia, Franca Iacovetta, Iacovetta and Korinek (p.19) and Marlene Epp, below.

${ }^{243}$ Donna R. Gabaccia. We Are What We Eat: Ethnic Food and the Making of Americans. (Cambridge: Harvard University Press, 1998), pp. 45-51; Howard Palmer. "Reluctant Hosts: Anglo-Canadian Views of Multiculturalism in the Twentieth Century," Immigration in Canada. Gerald Tulchinsky, ed. (Toronto: Copp Clark Longman, 1995), p.315; Langfield and Maclean, Speaking to Immigrants: Oral Testimony and the History of Australian Migration, 103

${ }^{244}$ Forchner, pp. 233-4.
} 
The Krolls' apparent adherence to their traditional food suggests that for both practical know-how and emotional reasons, traditional food practices were largely maintained. Helma was the primary cook in her home, and although food is not a central topic in her correspondence, references to food suggest that for the most part, Helma resisted conforming to the much-heralded 'convenience food' which 1950s North American culture had adopted. ${ }^{245}$ Like many other postwar immigrants, Helma was not won over by tinned food. ${ }^{246}$ Shortly after her arrival, she observed the lack of vegetable gardens, which consequently affected the Canadian diet. "There are not many fresh vegetables. Most often the cook opens a tin with prepared vegetables for the meal. We are not too fond of it; we feel they are overcooked and have no taste. ${ }^{, 247}$ Helma seems to have remained faithful to home-grown or market-bought vegetables, free-range eggs, fresh meat (which they often butchered) and fish; in fact, when looking at properties, the potential for a vegetable garden consistently arose. Helma seems to have also stayed loyal to traditional recipes. In Canada, she had access to "everything [they] were missing in 1947 ," but, recognizing that she was not much of a cook, asked her mother-in-law to send a "good cooking book" for her birthday. ${ }^{248}$ German print was likely part of this equation; however, by specifically ordering a cookbook from Germany, Helma also displayed her desire to adhere to traditional German recipes - food she knew. As an East European

\footnotetext{
${ }^{245}$ Joshua Gitelson. "Populox: The Suburban Cuisine of the 1950s,"Journal of American Culture 15, no. 3 (1992): 73-78. Gabaccia, p.62, Korinek points out that American and Canadian foods were essentially the same during this period. Roughing it in the Suburbs. (Toronto: University of Toronto Press, 2000), p.191. It is interesting to note however, that only $47 \%$ of Chatelaine's recipes involved processed foods (usually Campbell's soup or tinned vegetables). Chatelaine recipes focused on providing thrifty family menus. Korinek, p.187.

${ }^{246}$ Iacovetta and Korineck, Sisters or Strangers: Immigrant, Ethnic and Racialized Women in Canadian History, 200-1.

${ }^{247}$ Helma Kroll to Eleonore Scholz and Richard and Elfriede Kroll. October 16, 1954. Book 2 p.5.

${ }^{248}$ Helma Kroll to Eleonore Scholz and Richard and Elfriede Kroll. January 13, 1955. Book 2 p.17.
} 
immigrant attested: "Food is so important, a part of your culture." ${ }^{249}$ Whether consciously or not, Helma chose to retain this aspect of her roots. Dinners were traditional German meals, and never included North American 'novelty' dishes like rice or pasta. ${ }^{250}$ Helma continued to prepare homemade delicacies such as "German 'Streusel'- crumble-cake" and served them to Canadian guests; she and Reinhard also relished cookies — which tasted 'homey' - that arrived through the post from their parents, a practice that had persisted since the refugee camps. ${ }^{251}$

Yet, as Marlene Epp contends, for immigrant women the "preparat[ion], serving, and eating [of] meals is often the site at which the old and new worlds meet." ${ }^{, 252}$ Like many postwar immigrant families, the Krolls' grocery list reflected that of a 'hybrid diet. $^{, 253}$ Although Helma generally adhered to German recipes and cooking methods, the same did not necessarily apply to the children's diet. Helma and Reinhard ate 'German food' for their three meals, but the children had 'Canadian' breakfasts and lunches: "Cheerios, Shredded Wheat...Campbell's tomato soup and Kraft Dinner or canned spaghetti -- just like every other kid [they] knew." ${ }^{254}$ Helma's motives in this respect are not clear, but likely such a Canadianization was motivated by a combination of her children's pressure, the food's ease of preparation, and its low cost. ${ }^{255}$ In a revealing passage, Helma wrote following Ursula's birth that she was "surprised and thankful at how easy it is to feed little ones. All baby-food, fruits, main courses, chicken, vegetables etc. well prepared in jars, two for nineteen [sic] cents, I could not make any meal for this

\footnotetext{
249 "Part of Your Culture," Bruce, p.152.

${ }^{250}$ Email from Beate Myhill, March 4, 2006.

${ }^{251}$ Helma Kroll to Eleonore Scholz and Richard and Elfriede Kroll. January 8, 1956.Book 2 p.55; Helma

Kroll to Eleonore Scholz and Richard and Elfriede Kroll. January 2, 1958. Book 2 p.98.

${ }^{252}$ Epp Sisters or Strangers, 315.

${ }^{253}$ Iacovetta and Korinek, Sisters or Strangers, 211.

${ }^{254}$ Email from Beate Myhill, March 4, 2006.

${ }^{255}$ Iacovetta, Canadian Woman Studies, 20.
} 
price. By the way, Ursula is a Canadian. ${ }^{256}$ Evidently, there were economical advantages to prepackaged foods, and Helma was fully prepared to take advantage of them. In this respect, she fell in line with North American women (immigrants and native-born), who, although wooed by food companies, bought new innovations in frozen, dehydrated, and canned food only when it served their immediate interests; with few exceptions, they remained true to their tried, tested and true practices. ${ }^{257}$ In addition, Helma appears to recognize the relationship between nationality and food, linking Ursula's Canadian diet to her Canadian citizenship.

Tellingly, food gains a place in Helma's letters, however, in both Helma's and Beate's oral testimony, it receives scarce attention. Perhaps Helma simply does not view it as significant, which would make sense given the postwar era acceptance of ethnic food-perhaps the only aspect of ethnic identity that the greater Canadian culture accepted and even celebrated. Though some agencies and social workers attempted to 'transform' new immigrants' dietary customs according to the Canadian norm, the presence of articles featuring 'ethnic cuisine' in magazines such as Chatelaine indicate a tolerance and a degree of appreciation for such diversity, even if limited. ${ }^{258}$ Arguably, Canada's acceptance of difference was often on a rather superficial level; however, in theory, many Canadians liked to emphasize Canada's 'cultural pluralism' in juxtaposition to the United States' 'melting pot' dogma. ${ }^{259}$ Though in reality, the assumption that new immigrants would adhere to the dominant norms often prevailed, 'less threatening' forms

\footnotetext{
${ }^{256}$ Helma Kroll to Eleonore Scholz and Richard and Elfriede Kroll. August 1, 1956. Book 2 p.71.

${ }^{257}$ Laura Shapiro, "Something from the Oven," Something from the Oven: Reinventing Dinner in 1950s America. (Toronto: Penguin, 2004),.43-84.

${ }^{258}$ Iacovetta and Korinek, Sisters or Strangers. Of course, such 'difference' was appreciated so long as it remained within a standard of relative Canadian norms. Also, see Iacovetta, Canadian Woman Studies, 15.

${ }^{259}$ Iacovetta, Gatekeepers, Chapter 2.
} 
of diversity, such as food, dance and music, were considered acceptable. ${ }^{260}$ In accordance with the testimony of other German-Canadian immigrants, the Krolls experienced an acceptance of "cultural diversity" in Canada which they perceived to be missing in the United States; even if not always understood, their unique 'German' practices, such as diet and their celebration of Christmas, were accepted and even appreciated. ${ }^{261}$

The Krolls' adoption of 'Canadian' ways became more apparent as time passed and their finances stabilized. Given their shortage of capital, the Krolls were initially unable to partake in the market economy; other priorities took precedence over consumer goods. As immigrants, the Krolls had decreased access to benefits, such as medical and dental; thus, much of their 'surplus' earnings went towards such services. Ursula's birth was very expensive for the Krolls; she was born soon after Reinhard acquired fulltime work, and therefore, was not covered by the company's medical plan. With regards to dental care, the Krolls could not afford to visit a dentist for their first couple of years. However, this too became a priority after a visit to the dentist revealed that Beate had a cavity. After this,

even if there was no money, there was no money to buy snow suits or anything, [the Kroll children] always went to the dentists every six months....Dental care, or health care or anything like that, that was an essential. [The Krolls] could make do and [Helma] would save, [the family] could do without other things. ${ }^{262}$

The Krolls adopted North American spending habits quickly, despite their frugalness. A postwar immigration filmstrip advertised that "Many Canadian families buy expensive things, like furniture and appliances, on the installment or 'hire-purchase' plan. After a

\footnotetext{
${ }^{260}$ Iacovetta, Gatekeepers. Chapter 2.

${ }^{261}$ Interview with Beate Myhill, August 9, 2005 p. 18; also see various testimonies in Forchner, a strong theme is one of acceptance. For example, Petra's story, p.70.

${ }^{262}$ Interview with Beate Myhill, June 20, 2005. p.p. 18-19.
} 
small down payment, they pay off the balance in monthly installments. Meanwhile, of course, they have had the use of the article while they pay for it." ${ }^{263}$ The Krolls' first purchase on credit occurred quickly (within six months of their arrival) on an item they deemed essential: a used vehicle for Reinhard, which offered the family independence, but more importantly, regular transportation to work. They justified their plans to their parents, and wrote that particularly in the winter, "Here a car is not a luxury, it is a necessity." 264 Reinhard had been advised by his friendly coworkers that it was advisable to get some bank credit "No matter if you need some money or not... so that [they could] get a credit rating." 265 They acquired a bank credit of $\$ 250$, which meant monthly payments of $\$ 21$, which at the time, was "not so easily done." ${ }^{266}$ As the Krolls found their footing, however, the 'essentials' were joined by additional purchases. Within three years, a vacuum cleaner, washing machine, freezer, and even a used television were joined by a newer car, and initiated the Krolls' entrance into consumer society. Though generally speaking, Helma “order[ed] everything by mail-order [since she was] not a good shopper in stores and [they couldn't] afford to buy more than [was] really necessary," the Krolls also engaged in Canadian shopping habits. ${ }^{267}$ Every Christmas, their children were indulged with presents, both those of a practical nature, and those strictly for fun. Helma and Reinhard braved the Department stores to go shopping during their second Canadian Christmas; however, with limited cash on hand, they wrote that "with some hesitation

\footnotetext{
${ }^{263}$ Immigration Branch filmstrip as cited by Bruce, p. 84 .

${ }^{264}$ Helma Kroll to Eleonore Scholz and Richard and Elfriede Kroll. No date. (located between May 23, 1955 and June 23, 1955) Book 2 p.33. It is amazing to note the similarity between Helma's comment and Ibolya Grossman's. With regards to buying a car, though it was a symbolic purchase, Grossman wrote "This would have been a luxury in Hungary but in Canada it was a necessity" because of the distance from work. Grossman, p. 102.

${ }^{265}$ Interview with Helma Kroll, August 9, 2005 p. 5.

${ }^{266}$ Helma Kroll to Eleonore Scholz February 8, 1956. Book 2 p.58.

${ }^{267}$ Helma Kroll to Richard and Elfriede Kroll. October 20, 1956. Book 2 p.75.
} 
"we have gotten a 'Credit Card'- - now we are real Canadians!"268 Three years after the Krolls' arrival, Helma wrote:

Today, three years, ago with many uncertainties and a churning stomach, we had our last supper on the boat and were waiting to see what will happen next. - Those were very long years, which went really fast...how much we've accomplished! ${ }^{269}$

Poignantly, she expresses guilt for how well they have done. In reference to upgrading their car, she wrote "if we tell someone about the car, we have a bad conscience, (like if you tell your mother you have a tear in your new dress) - we should not have it yet.",270 Seemingly, the Krolls' financial conditions had ameliorated substantially (which again conforms to the German-Canadian model). ${ }^{271}$ Plausibly, because they were on stable ground for the first time in many years, this security came with mixed feelings. Though they were admittedly not satisfied with Reinhard's professional development (particularly in letters to his parents), the Krolls were grateful for the lengths they had come.

Undoubtedly, the Krolls' most significant material acquisition was the purchase of their first home. For Canadian immigrants, home-buying was a crucial step in developing a sense of security and permanence. ${ }^{272}$ For German-Canadians in particular, home ownership was a priority and an occasion which usually came within the first few years of

\footnotetext{
${ }^{268}$ Reinard Kroll to "everyone we can think of and want to wish a Merry Christmas to." December 12 , 1956. Book 2 p.78.

${ }^{269}$ Helma Kroll to Eleonore Scholz and Richard and Elfriede Kroll. Setpember 27, 1957. p.93.

${ }^{270}$ Helma Kroll to Eleonore Scholz and Richard and Elfriede Kroll. Setpember 27, 1957. p.93.

${ }^{271}$ McLaughlin, p. 17.

${ }^{272}$ Dreisziger et al. note that homes became viewed as an investment-a piece of property and real estaterather than an item to be passed down to the next generation. Dreisziger, NF with ML Kovacs, Paul Body, and Bennet Kovrig. Struggle and Hope: the Hungarian-Canadian Experience. (Toronto: McClelland and Stewart with the Mutliculturalism Directorate, Dept. of the Secretary of State, and the Canadian Government Publishing Centre, Supply and Services Canada, 1982), p.186; Iacovetta, Such Hardworking People, pp.70-71.
} 
immigration. ${ }^{273}$ German friends and acquaintances of the Krolls' quickly purchased homes; three years following their first immigration, the Krolls' dreams were in "high speed" as they started to search for a house of their own. ${ }^{274}$ It was a challenge; they needed an affordable home within the realms of 'civilization,' on a property where they could have a vegetable garden and grow trees for their developing business. On the whole, land was the most important buying feature, for it would provide a "life line" with a future nursery. ${ }^{275}$ They finally found their home in Richmond. For the Kroll parents and children, the sense of ownership was significant; Helma considers it likely the couple's proudest moment. ${ }^{276}$ This sentiment flowed throughout the family, even down to young Ursula, who on moving day, "ran happily from one room to the next, 'Mine.",277 For Beate, pride not only stemmed from the purchase, but also from the home's features: it had two stories, two bathrooms, and a "real kitchen" with a "real kitchen counter," which made dishwashing a desirable chore. ${ }^{278}$ Despite a garden that needed "a lot of work," Helma wrote "it is what we were dreaming of.",279 Though the move would require a subsequent adjustment for the children, the young Krolls soon found that there was a variety of new playmates from whom they could choose. Though Helma and Reinhard had not met their new neighbours, the socioeconomic level of Richmond made them feel that neighborhood would be a better fit. Nevertheless, socialization would continue with

\footnotetext{
${ }^{273}$ Gumpp, Chapter 2; Forchner, see Wolfgang's story, p.196; Writing in 1964, Allen states that in comparison to the national average, German immigrants will "buy fewer telephones but far more houses." Allen, p.52.

${ }^{274}$ Helma Kroll to Richard and Elfriede Kroll. January 2, 1958. Book 2 p.98.

${ }^{275}$ Interview with Helma Kroll, August 9, 2005 p. 10.

${ }^{276}$ Interview with Helma Kroll, August 9, 2005 p. 16.

${ }^{277}$ Helma Kroll to Eleonore Scholz and Richard and Elfriede Kroll. July 5, 1958. Book 2 p.107.

${ }^{278}$ Interview with Beate Myhill, August 9, 2005 p. 10.

${ }^{279}$ Helma Kroll to Eleonore Scholz and Richard and Elfriede Kroll. May 19, 1958. Book 2 p.105.
} 
their old friends as well. Financially, though annual payments might be tight, the Krolls looked to the future with optimism and more certainty. They now had permanent roots.

The Krolls' second booklet of letters does not extend to their formal acceptance as Canadian citizens; however, the steps they took during their first $3 \frac{1}{2}$ years demonstrate that they had begun the process of 'becoming Canadian.' Unlike the experience of some immigrants, Helma and Reinhard's citizenship 'ceremony' in 1959 was an anticlimax; nevertheless, it was an event clearly remembered by Helma. Forty-six years later, there is no ambiguity as to her national identity. Helma identifies herself as "a Canadian with a German background." She states "Canada gave us a home at a time we needed it. We and our family needed it. We had to work hard here, but certainly we were helped, we were welcomed.... And our children had a future here. We didn't do it for our future, we did it for our children's future."280 Subsequent visits back to Germany further confirmed where she belonged; despite a pleasant trip back, she looked to returning 'home' to Canada. ${ }^{281}$

\footnotetext{
${ }^{280}$ Interview with Helma Kroll, August 9, 2005 p. 11.

${ }^{281}$ Interview with Helma Kroll, August 9, 2005. p.11. This is further confirmed by the experience of another German immigrant: Lothar Bode, in Trudy Duivenvoorden Mitic ed. People in Transition: Reflections on Becoming Canadian. (Markham: Fitzhenry \& Whiteside, 2001), p.58.
} 


\section{Conclusion:}

Initially, this thesis was intended to be a study of the Krolls' immigration to Canada, with a specific focus on adaptation to a new land and culture. Furthermore, because Mrs. Kroll was central to both the letter writing and interview process, the original intention was to concentrate especially on the female migration experience. However, in the course of researching and writing the thesis, this ethnic and gender analysis acquired further dimensions. An understanding of Canadian adaptation required knowledge of the formative European years and traumatic refugee camp experience. Moreover, the gender analysis could not concentrate on Helma Kroll separate from the family that shaped her identity and her life. Hence, home and family, in both Europe and Canada, became central themes in this case study of a migrant experience.

When the project was completed, the Krolls' 'pre-Canada' life formed two thirds of the study while only one third dealt with life in Canada. This apparent 'disparity' between intention and end result could be attributed to the amount of interest which this pre-immigration period evoked; however, a more judicious explanation is found in a statement by Marlene Epp:

...for all Canadian refugee women, the homeland is much more than a starting point or background, but represents a crucial aspect of identity for individuals who have a sense of "being simultaneously "home away from home" or "here and there." 1

In a thesis which focuses on the experience of Canadian newcomers, one must remember that life did not begin in Canada; rather, it was shaped by prior experiences which had

\footnotetext{
'Steven Vertovec and Robin Cohen, 'Introduction,' in Vertovec and Cohen, eds, Migration, Diasporas and Transnationalism (Cheltenham, UK: E.Elgar, 1999), xviii as cited by Marlene Epp, "The Semiotics of Zwieback: Feast and Famine in the Narratives of Mennonite Refugee Women," Marlene Epp, Franca Iacovetta and Frances Swyripa, eds, Sisters or Strangers: Immigrant, Ethnic and Racialized Women in Canadian History, (Toronto: University of Toronto Press, 2003), 318
} 
occurred in Europe. Particularly given my work with Mrs. Kroll, I came to see that the present is not isolated from the past. The Krolls' experience as new Canadians was determined in large part by the events which preceded their immigration. Conditions in postwar Germany, the Soviet occupation, and time spent in refugee camps greatly influenced how the Krolls would adapt to life in a new land. Likewise, conditions of the past as well as the conditions of the present determine how such experience is recalled.

Five decades after immigration, Helma states:

Canada gave us a home at a time we needed it. We and our family needed it. We had to work hard here, but certainly we were helped, and we were welcomed. And I think that's it. Our children had a future here; we didn't do it for our future, we did it for our children's future. ${ }^{2}$

As a result of Helma Kroll's testimony, family became a central theme of this thesis. The Krolls' migration to Canada resulted in financial strain, homesickness, cultural shock and professional displacement; however, within Helma's testimony, such trials are minimized by the fact that Canada offered the Kroll children future opportunity. Throughout her letters, memoirs, and oral testimony, Helma consistently frames her migration experience around the family: how the outside world pervaded the domestic realm, how the family coped with changing circumstances, and how they worked towards a future in which the family unit was prioritized.

Before I had direct contact with Mrs. Kroll (particularly through interviews with her) I did not appreciate the significance of the family unit to the Krolls' story. For me, focusing on the family as central to the analysis was the most significant alteration of course which occurred during the thesis-writing process. Throughout the Kroll letters, Helma's memoir, and Helma's testimony, the family prerogative is continually

\footnotetext{
${ }^{2}$ Interview with Helma Kroll, August 9, 2005. p.11
} 
reaffirmed. Mrs. Kroll thought about the family as a unit, she used 'we' when discussing family decisions and activities and often did not differentiate between her role and that of her husband. There is little discussion of Helma as a woman; rather, the focus, if on Helma at all, is as a member of the family unit. Mrs. Krolls' narrated script and her responses to my questions revealed that her understanding of her story was quite different from mine. Nevertheless, though this discrepancy illustrates how academics (like myself) are prone to impose particular understandings or categories upon a given experience which the subject does not share, a gendered perspective allowed me to bring a new level of understanding to the 'family experience.' Consequently, while my thesis emphasizes the family, it considers how gender affected the relationships among Helma, Reinhard and their children, and thus problematizes the family as a unit.

Migration entailed sacrifice, risk, and years of struggle; yet for Helma, such trials were worthwhile due to a just cause: Gerd, Beate, Hartmuth, and subsequently, Ursula. Yet even for such a worthy sacrifice, migration was painful-if for no other reason than the physical distance which separated Reinhard and Helma from their respective families. From Helma and Reinhard's focus on their own small family, one can infer that their personal values were family-oriented. Significantly, the importance of family to the Krolls both produced the letters and made them available for us to read. The Krolls' correspondence was compiled into a collection in order for Helma's descendants to learn about their heritage. The Kroll letters were born from the need to maintain contact with family throughout the migration process.

When I first heard the Krolls' story, I was very intrigued. Admittedly however, when I first read the letters I found them not as 'exciting' as I had hoped. This, however, was part of the learning curve in working with immigrant letters as a primary source. The 
less I thought of the letters as a content-based source, and the more I analyzed them in terms of their significance as communication, the more social history I found within them. Through such a change in perspective, the letters can be perceived as conversations in which Helma and Reinhard kept touch with their families, similar to ones I might have with my parents on the West Coast.

Written correspondence met a number of functions: it was used to acquire material goods, it helped to stabilize the family during their move(s) and subsequent settlement, and it reaffirmed their cultural heritage. Above all else, however, the Krolls' primary purpose in letter writing was to ensure that trans-Atlantic migration would not sever ties; for both senders and recipients, the Kroll letters provided a physical space in which familial relationships could continue. The regularity and length of time over which correspondence occurred illustrates its importance to all parties: to Helma and Reinhard, letters were a link to their homeland and families; to their respective parents, they nurtured central relationships and alleviated parental anxiety and concern.

Whereas letters were a coping mechanism for the Krolls, they are also a fruitful source of historical evidence for the contemporary reader. Nonetheless, though the letters offer valuable insight into the Krolls' experience, they are not the sole source of 'truth.' Rather, the story that they conveyed is just one version of the Krolls' experience, and it is joined by other accounts: a corresponding memoir and Helma's oral testimony. Through such additions, new questions are raised, particularly those relating to memory. Memory is often held suspect by 'traditionalists' within the historical field; however, the construction of the past produces significant insight into both past events and present values. Just as the letters were constructed for Helma's and Reinhard's respective parents, Helma's oral testimony is constructed for a modern academic audience. 
The construction of such experience is pertinent to a gendered and family-oriented analysis of the Krolls' migration. Helma orally recounts her family's story as an elderly female; just as within the memoir, this oral narrative is framed around the family. The persistence of this theme suggests that family is still a dominant concern in her life. Moreover, gender interests implicitly have shaped the picture of the family. Had the same experience been retold by a different individual, particularly male, it is likely that Helma's scripted themes would have been absent or underrepresented. For example, had Reinhard narrated the same experience, he might have focused on work, the fiscal value of their home, and the type of economic improvements they made. Though such themes occasionally arise within Helma's oral testimony and in some of the letters, they are not dominant. Helma's letters, memoir and oral testimony highlight the children, the household, furnishings, food, and daily chores - all of which tie the family to the domestic realm. Who 'wrote' the script of the Krolls' experience is thus crucial in understanding it, as it 'happened.'

From Helma's perspective, we have been introduced to a difficult, yet satisfying story of postwar immigration. The Krolls left East Germany during the post war era as political refugees, due to political pressures which would severely impact their life and the futures of their children. In West German refugee camps, the family found itself in a place of limbo in which material goods, employment, and a future destination were somewhat precarious. After finally reaching Canada, the Krolls continued to be challenged financially; instead of finding the 'land of milk and honey,' they encountered years of hard work fuelled by determination. Nevertheless, throughout accounts of work, daily struggle, and material possessions, the Kroll family remained as one. They 
consciously chose their path in order to remain together, placing family before other more immediately 'rewarding' alternatives.

Space, home, and family are highlighted in my thesis. The notion of 'home' and what constitutes this space consistently arose throughout the Kroll migration, from East Germany to Canada. I discovered that home is related to material goods, but moreover, it corresponds to concerns for the future, particularly the uncertainty that lies within it. My understanding of what constitutes home was changed by the letters; the importance of one's own space, above and beyond being with the family unit, was a crucial insight into understanding the Krolls' migration, and is often missing in such an explicit form in historical accounts. It is the lack of focused studies which prevents a serious discussion of such 'minute' details of space and home, and the family which is housed within.

This thesis also contributes to an understanding of the refugee camp experience. I dealt with this subject differently than my predecessors: to begin with, I look at different refugee camps. Milda Danys and others have studied the Displaced Persons (DP) camp experience; however, the West German refugee camps in which the Krolls were housed were not the same - they came several years after the post war DP crisis, in an international environment which had changed substantially. Moreover, I examined camplife from a gendered perspective, with a heavy emphasis on the family. In this respect, my approach is similar to Mona Oikawa's examination of Japanese Internment camps in Canada. Nonetheless, my study is more in-depth; it addresses the 'every day' experience which constructed refugee camp life; in addition to a focus on space (like Oikawa), I examine material goods, work and family.

Franca Iacovetta's work has had the greatest theoretical influence upon my thesis. Her early text Such Hardworking People probes many issues which I also examine, such 
as work, gender, and the family; much of her subsequent work looks at material culture, with regard to gender. While my thesis is not groundbreaking in this respect, I do feel that it brings new evidence to the forefront, and thus provides a new understanding of immigrant dynamics, in so much as gender, work, and the family are concerned. What emerged in both the Krolls' letters and the oral testimony was that the family unit was of the utmost importance; work was performed in and outside the home with the interests of the group kept in mind. Sacrifice, perseverance, and hope for the future provided the fuel that kept the Krolls going.

The Krolls' immigration story is one of success. Though this thesis does not continue beyond the family's first three years in Canada, Helma's willingness to share her experience, plus the fact that she remained here, suggests that she regards it as positive. Though Helma and Reinhard never became 'rich' by the standards of some, they built a life here. They bought a home, were each employed by the Canadian government, and more importantly raised four children. Unsurprisingly, it is the latter which Helma claims to be her most significant accomplishment. ${ }^{3}$

Postwar immigrant testimony often asserts that citizenship and national (self) identity are two very different affairs. After spending the majority of their life in Canada, some immigrants maintain that Canada is where they live and hold citizenship, but not the place they call home. ${ }^{4}$ Helma Kroll adheres to a very different immigrant model. Five decades after migration, she identifies herself as "a Canadian with German background;"

\footnotetext{
${ }^{3}$ Interview with Helma Kroll, August 9, 2005. p.17

${ }^{4}$ See for example Milda Danys, DP Lithuanian Immigration to Canada After the Second World War (Toronto: Multicultural History Society of Ontario, 1986), pp .307-312. Also see Barry Broadfoot, The Immigrant Years: From Europe to Canada 1945-67 (Vancouver: Douglas \& McIntyre, 1986). While his chapter on "Becoming Canadians" is reminiscent of the Krolls, testimony in the previous chapter, "We Never Had It So Good" suggests a more permanent Canadian-immigrant divide. Pp. 178-179, 204-207; or "Our Life is Here," Bruce, Jean. After the War. (Ontario: Fitzhenry and Whiteside, 1982), p.170
} 
furthermore, she insists that this shift was swift. At first, the Krolls had to accept that Canada was their new home: circumstances were such that the family felt that they had nowhere else to go. However, such an acceptance of necessity quickly changed. Within five years, the Krolls stopped comparing Canada to Germany, and accepted their new country for what it was. They came to enjoy their adopted homeland; on subsequent visits to Germany, they looked forward to returning 'home'-to their house, family, and life, in Ottawa. $^{5}$

For a contemporary reader, the Krolls' immigration story is fraught with a series of extraordinary events and experiences. Yet, for Helma and her daughter Beate, what the letters document is not an extraordinary experience, but the common experience of a twentieth century immigrant - the way Susanna Moodie documented an immigrant experience of the 1800's...It's not that there were any extraordinary crisis other than daily life, and that's what the letters document for the twentieth century. ${ }^{6}$

As narrator, Helma Kroll shares her migration story as she remembers it, and as it was recorded through letters for the benefit of her family. She argues that this experience was not exceptional in the postwar context, and perhaps she is right. However, the Krolls' story is far from ordinary. Apart from the 'events' which took place, the themes which emerge within its narrative testify to an individual experience. Framed by a specific set of values, 'daily life' is given new meaning. The Krolls' migration to Canada is not 'typical' of the postwar immigrant experience, but it is one example thereof. It is not the story of the German-Canadian, or the Iron Curtain refugee, or even the postwar 'New Canadian'; rather, it provides a way in which to think of post war migration, along lines of gender, family, and ethnicity. Above all however, this is the story of the Krolls; through their

\footnotetext{
${ }^{5}$ Interview with Helma Kroll, August 9, 2005. p.15

${ }^{6}$ Interview with Beate Myhill, August 9, 2005. p.18
} 
letters, and Helma Kroll's oral testimony, we are granted the rare privilege of a private window to the past.

This thesis challenged my own perseverance to a great degree; nonetheless, it is an experience which I regard as wholly valuable and worthwhile, both personally and academically. I can, however, envision more being done with both the Kroll letter collection, and my own research. Particularly in terms of analysis, different approaches could be taken; I chose to take a gendered perspective, and thus highlighted certain relevant themes, but a different researcher might be struck by others. Immigrant acculturation could especially be further developed, both in terms of the letters, but also in the testimony of the Kroll children - specifically Beata Myhill, who had to confront the Nazi stigma as a child during the fifties and sixties, as well as Germany's checkered past. More generally, the Kroll story could also serve as a basis from which the GermanCanadian experience could be further explored. With respect to the letters, there are several more volumes of a later date which have yet to be translated. For an ambitious German-literate historian, these could serve as a fresh source to study German-Canadian acculturation. Moreover, the letter collection could be examined from a literary perspective. While the English translation is a legitimate collection, a study of its translation might prove interesting in itself; in addition, a focus on the original German version could be very fruitful. 


\section{Appendix: Lost in Translation}

As explained in Chapter 1, the Kroll collection was originally written in German and has only been translated into English within the past decade. The English collection (on which I based my analysis) represents the knowledge that Helma was transmitting to her children and grandchildren. However, it differs in some respects from the German collection as it was originally composed. Helma translated her and her husband's German correspondence into English, placing the translations into several volumes for family and close friends to read. By its nature, translating is a form of editing. Furthermore, apart from language, discrepancies exist between the two collections. No matter how true Helma may have attempted to remain to her correspondence, she has an unconscious, vested interest in having a specific voice amplified, as has been illustrated within oral life recollections. ${ }^{1}$ Helma's role as editor is both interesting and troublesome because she is without the training to recognize her inherent bias. Moreover, within that framework, Helma chose to remove certain letters and excerpts. Chapter One provided some general discussion of the letter editing process, and how it parallels oral testimony. This appendix offers a discussion comparing the two collections in terms of content; as such, it will ask critical questions regarding the editing process: what did Helma choose to leave out, what did she choose to leave in, and most importantly, what were her motivations in doing so? Before we examine Helma's reason and method in the editing process, it is helpful to briefly address how letters are generally presented by a professional historian; this will aid in demonstrating the limitations and special circumstances of the Kroll collection.

\footnotetext{
'Graham Dawson, Soldier Heroes, British Adventure, Empire and the Imagining of Masculinities (London: Routledge, 1994), pp.22-23 as cited by Penny Summerfield, Reconstructing Women's Wartime Lives: Discourses and Subjectivity in Oral Histories of the Second World War (Manchester: Manchester University Press, 1998), p.17
} 
How an editor chooses to select letters and the letters' content directly influences how a readership receives and understands the given material. ${ }^{2}$ When working with collections such as the Kroll letters, there is a dual challenge: editing and translation. Though historians' utilization of letter sources has varied, two challenges remain consistent: how to maintain the authors' voice and translate accurately, while staying true to the letters' 'integrity. ${ }^{3}$ Undoubtedly, this latter challenge is aggravated when translation is required in addition to editing. Published letter collections generally have a defined purpose: to educate their audience and illuminate a certain facet of history, often addressing a particular set of concerns. The historian edits out 'irrelevant' material according to his or her goal in using the letters. It is crucial to note that this term is highly subjective, for its meaning depends upon the form of analysis with which the letters are approached, in addition to the historian's focus of research. Generally speaking, in a published collection of letters, the preface will inform the readers how the collection has been edited. For example, an author of such a work might state that they have omitted references to health, previous correspondence, other immigrants (ie: those not immediately involved in the story), the crossing of the Atlantic, prices of food, and the like-all done in an effort to make the collection coherent and comprehensive. ${ }^{4}$ As Gerber crucially points out, however, there is a significant difference in how one presents letters for publication versus their analysis. ${ }^{5}$ Primarily, Helma edited the letters to make a

\footnotetext{
2 David A. Gerber, "The Immigrant Letter between Positivism and Populism: The Uses of Immigrant Personal Correspondence in Twentieth-Century American Scholarship," The Journal of American Ethnic History 16, no.4 (Summer 1997): 20.

${ }^{3}$ Gerber, The Journal of American Ethnic History, 19.

${ }^{4}$ Gerber, The Joumal of American Ethnic History, 19.

${ }^{5}$ Gerber, The Journal of American Ethnic History, 19.
} 
readable account of her family's history for family and friends; it is noteworthy that such an account would also have to accord to an image she felt comfortable presenting.

The letters themselves have been transcribed twice; I have not had access to the transcription of the letters from handwritten German to typed German. ${ }^{6}$ However, based upon the very few differences between the English letters and the transcribed German letters (those which I have had translated), I have made the presumption that little or no editing occurred during this initial process. Admittedly, this is a assumption on my part; however, given that I have not seen the original letters in their handwritten form and that editing clearly did occur in the second step, this is the basis from which I am working. Consequently, 'original' will henceforth refer to the German letters as I encountered them. My central challenge in working with this original collection was based upon a language deficiency; due to my lack of German, I employed Bob and Inge Harris to translate a mean selection of the German letters as they were initially transcribed. ${ }^{7}$ Unfortunately, time limits imposed restrictions upon the number of letters which could be interpreted. In an arbitrary decision, I chose to work primarily with correspondence in Volume One, which extended from the collection introduction until the Krolls' arrival in Canada (excluding the pre-1953 letters between Helma, her grandmother and mother). Eighteen letters, absent from the English volume, were translated and in addition, eight

\footnotetext{
${ }^{6}$ The initial transcription occurred because the Kroll children had difficulty reading cursory German.

${ }^{7}$ Bob and Inge Harris are my aunt and uncle. Their background offers an interesting foray into the Krolls' story. Inge was born and raised in Germany, and immigrated to Canada in the 1960s after she met Bob, who was stationed there with the Air Force. In the early 1990s, both Bob and Inge moved back to Germany, where Bob was employed as an industrial manager for over ten years. Both Inge and Bob are fluent in English and German; their translation was particularly insightful as their mother tongues are different, and therefore, each brought slightly different understandings to the English and German written word. What was extremely telling for me was that during the translation process, Inge could relate to much of what Helma had written, leading me to believe that there is much more to be written about this subject, particularly the Canadian/German divide of culture.
} 
letters, existing in each language, were compared in terms of content. ${ }^{8}$ While this modest sample inevitably leaves room for error, it still provides a base from which the accuracy of Helma's translation may be evaluated; more importantly, it also facilitates the discussion of what was included and excluded in the letter collection with which I worked: that which was deemed insignificant by Helma, and that which was judged undesirable to include.

In reference to the accuracy of the letters' translation, my translators concluded that Helma had 'interpreted' the German documents well. ${ }^{9}$ Thus, save for my inability to read German — which necessitated that I work through a third party — from the viewpoint of this thesis, the translation of these letters is straightforward. The editing of the letters, however, is another matter altogether and thus requires the most attention.

When asked about how she edited the collection, Helma replied that she took out the "repetition. The letters are repetition." Helma approached the letters as a means "to preserve the family history." ${ }^{10}$ In a conversation with her mother, Beate gave a more thorough account of the editing process, which Helma affirmed:

The stuff that was edited out was just the sort of 'hi, how are you;' the stuff that is repetitious where you talk about the greetings, the non-events. Anything that was an event that happened was put in the letters, even at first I think you weren't going to include the stuff about what happened at the end of the war, right, and that got written later on, and was going to be just for me and Ursula....But time passes. There was nothing edited out in terms of bad things that happened, or conflict or anything like that because so much history, so much time has past,

\footnotetext{
${ }^{8}$ In some cases, letters were translated by 'accident': Helma had already translated them but had transcribed the wrong date. I do not quantify this as 'editing out,' and have subsequently corrected' her oversight. In some respects, it worked in my favour, as I had a greater basis from which to compare the accuracy of Helma's translations than I had originally anticipated. However, as I discuss further, this is also problematic for it suggests a lack of precision in the transcription process.

${ }^{9}$ It is interesting to note here that both 'translators' made a distinction between translation and interpretation and in fact objected to the former term; because idioms are difficult to translate directly, they referred to their role as interpreting, and cited this as the critical undertaking. Interview with Bob and Inge Harris, January 3, 2006.

${ }^{10}$ Interview with Beate Myhill, August 9, 2005 p.14.
} 
there's no reason to keep anything like that out. The only thing that would be left out is stuff that would be boring. ${ }^{11}$

Here, Beate likely refers to Helma's rape; as she points out, with the passing of time this experience is easier to share, which accords with the experience of oral historians as well. ${ }^{12}$ That Helma chooses to leave in the rape is revealing; rape is an experience which is often bypassed in oral testimony, hence Helma's conscious decision to include it supports her assertion that events were not excluded during the editing process. ${ }^{13}$ If any experience were going to be left out, this would be a logical one. Within the translated collection it appears that indeed, no important occasions were skipped, and furthermore, no references were made to events which do not appear in the English collection. Given that the letters were written to the Krolls' parents in the first place, one would consequently expect their content to be fairly tame with little to conceal from other family members. Therefore, it seems logical that the translated letters would hide little, for if something were to be deemed too risqué for the English collection, there is a good possibility that it would never have been written in the first place. Nevertheless, there is information, sentences, paragraphs, and whole letters, which Helma chose not to include in the English translation.

According to her testimony, Helma removed that which she found repetitive or boring. In some respects, she proceeded along the same lines as the historian who does similar work. She often edits out greetings and references to people in Germany who do not play a large role in the Krolls' life, and, in a few cases, prices of goods as well. She

\footnotetext{
${ }^{11}$ Interview with Beate Myhill, August 9, 2005. p.14.

${ }^{12}$ Alistair Thomson, "Moving Storeis: Oral History and Migration Studies," in Oral History, 27, no.1 (Spring 1999): 35.

${ }^{13}$ Epp, Marlene. "The Memory of Violence: Soviet and East European Mennonite Refugees and Rape in the Second World War" in Journal Of Women's History 9, no. 1(1997): 63-65.
} 
also extracts much discussion of goods, parcels, requests and thank-you's for the latter, small talk, details of the children's illness, and, in general, descriptions of her environment. Likely, when Helma edited these letters, she herself found these references mundane, or felt that these themes had already been adequately addressed in the balance of the correspondence. Perhaps she envisioned that a character-type focus which would create a more 'enthralling narrative,' rather than one based upon 'miniscule details.' However, while Helma's supposition might hold true for her target audience, an academic readership examines these letters from a different perspective; thus, what Helma might deem unimportant could be quite significant to an historical study. For instance, in the original letter written aboard the ship to the grandparents, Helma recorded a long menu of what the ship served, but in the English translation, she edited this out. ${ }^{14}$ For the purposes of our particular study, the menu itself is not important, however, the fact that she listed it in such detail is significant. Though Helma might have felt this account to be excessive, for an historian such detail points to a postwar preoccupation with food -a notion that is further reinforced by Helma's subsequent observation in that same letter, that "Reinhard eats everything and collects [the family's] leftovers." The same is true for the repetitive discussions of goods, parcels, and packages. Though Helma's intended audience (her family) might find such information redundant, the repetition denotes the priority which the Krolls gave to such exchanges; by reducing their occurrence, analysis may be skewed.

In some instances, what Helma deems as repetitive is actually an important link in understanding the Krolls' story. She removes certain passages not in an effort to hide them, but seemingly because they were already 'mentioned' in other letters. However,

\footnotetext{
${ }^{14}$ Helma and Kroll to Eleonore Scholz and Richard and Elfriede Kroll. October 4, 1954. German Edition, pp.103-108; English Edition, Book 1 pp.59-62.
} 
some of these passages are important in understanding references contained in subsequent letters: removing such text increases the probability of confusion and misconceptions. For instance, Helma is ill in Berlin while the Krolls await their second interview; in the translated version, Helma briefly summarizes (in a narrator's commentary) that she "got a terrible flu" and thus "An interview with the Canadians had to be cancelled. They sent the message, I should hurry up to get well, which I did."15 Though this may seem adequate, the original letter was much more comprehensive and fully expressed the disappointment and gravity of missing such a date. What is very clear in this case is that the length of a given letter often reflects the gravity of a given topic or circumstance: Helma's discussion of the bad timing is more extensive in the German transcription, which gives the audience a much better sense of the seriousness of such a delay. In addition, the original letter explains that the children accompanied their parents to the second interview; this is completely absent from the English version. Helma very well might have deemed this unimportant; however, for a historian studying the immigration process, it is pertinent information.

Similar cases arise throughout Volume One. In particular, passages relating to Reinhard's work are often excluded. Though the English volume explores his professional (and coinciding political) challenges, this information is generally provided through Helma's written memoir/commentary, rather than through the letters; thus, it is a theme explored through a retrospective as opposed to a contemporary scope. Moreover, it is from Helma's perspective, and not her husband's. For Helma, perhaps the purpose of the letters is more weighted towards the immigration to Canada, rather than the emigration. Nevertheless, the 'push' is an important feature of any immigration story, and

\footnotetext{
${ }^{15}$ Helma, commentary 2001, English Edition, Book 1 p. 22.
} 
particularly because the Krolls came as 'political refugees,' such recognition is vital. The German letters provide a thorough account of Reinhard's work, his frustrations with his position, and the inherent job insecurity he faced under the Communist Party. Despite Helma's summary which gives her audience an overview of Reinhard's professional situation, it is only through reading the original letters that the reader is able to fully grasp Reinhard's reality. The contemporary (edited out) account clearly depicts the nature of his work: the extensive training it required, the level of professionalism it demanded, and Reinhard's accomplishments within it. Furthermore, the rapid disintegration of the profession under the Communist system is also alluded to. Reinhard writes "Direction and leadership are missing in many areas. I often arrived too late to prevent such stupid action." ${ }^{16}$ The letters draw a picture of how politics had begun to interfere with forestry 'productivity.' Helma does not edit out material which relates directly to Reinhard's persecution, but the letters which are 'missing' in the English translation express Reinhard's personal frustration with his inability to practice his profession due to the ineffectual governance which meant that ideological practices hampered the profession's previously high standards. The letters' direct reference to politics and defection to the West, in addition to Reinhard's own personal frustrations, provide additional information in explaining why the Krolls left. Conceivably, Helma might have omitted these letters in an effort to concentrate on the family's experience, not merely one member's.

Nevertheless, these omitted passages not only make the Krolls' story more 'real,' but they also make it easier to place in a historical context. This non-family related intelligence is in accordance with outside secondary sources; thus, not only would the inclusion of such

\footnotetext{
${ }^{16}$ Helma and Reinhard Kroll to Elfriede Kroll. May 3, 1953, German Edition, Book 1 pp.24-25.
} 
information bolster our understanding of the Krolls' personal experience, but it would also further validate the collection as a trustworthy source.

The same is true for the original documents' discussion of consumer goods. Throughout Volume One, Helma seems to remove many references to material items. For instance, within the letters written in the GDR, discussions regarding the shortages of gloves and jackets at the HO (a state run store in the GDR) are edited out. Again, this is unfortunate, for as a significant aspect to life in the GDR, the shortage of such consumer merchandise helps to historicize the Krolls' experience. Perhaps in retrospect for Helma, this component of her GDR experience holds little gravity; however, for her readers, perhaps even family members, this might be the sort of qualitative example to which they can relate - an ordinary item placed in a very foreign context - in order to comprehend that alien setting. In another instance, Helma excludes a different passage regarding material items; yet, more significantly, the omission is part of an omitted paragraph, rather than a complete letter; this suggests a very deliberate decision to disengage such material from discussion. ${ }^{17}$ The letter is written from the refugee camp, and the aforementioned passage refers to a broken alarm clock. The Krolls are dismayed by its malfunction; however, because it costs too much to repair, Reinhard will not "do anything with it" while at the camp. Evidently, the alarm is something special to have, for although Reinhard is mechanically inclined, and cites previous success with a "kitchen clock" and "hairdryer," "as far as the travel alarm is concerned, he [does not] dare to touch it." Reinhard's reluctance to tamper with the item does not just illustrate the Krolls' tight finances, but it also reflects the value of such merchandise, due to its shortage in post war

\footnotetext{
${ }^{17}$ Reinhard Kroll to Richard and Elfriede Kroll. March 1, 1954 German Edition, Book 1 pp.67-69; English Edition, Book 1, p.37.
} 
Germany. The Krolls' relative 'poverty' is addressed throughout the letters; however, the letters fail to incorporate such historicizing references. Again for an historical audience, these 'minute' facts help place the Krolls in Germany during the postwar era; they also add to a social history that extends beyond the Krolls alone.

It is precarious to leave out detail. To the author (someone who has lived through the experience), such 'trivial' information might seem like overkill; yet, for an audience it is often these 'minor points' which sharpen the senses and bring the history in letters to life. The aforementioned passages which concern Reinhard's job fall under this category; his expressed pride in his work transform the letters from a simple tool in historicization to something more: his detailed description of his work and his listed accomplishments affect how the audience receives him as a character, as a live human being who simply exists in another time. Though we learn from other letters that Reinhard is moderately successful within his profession, the personal significance his work holds for him is undermined by other correspondence which focuses more upon his role as a father and provider. Clearly, the audience's reception of the letters is altered by editing, as it relates to detail and the lived experience As a further example, in the English translations, though both Helma and Reinhard are quite vocal in their distaste for conditions at the refugee camp, Helma edited out letters which were more explicit and descriptive. In a letter dated October 24, 1953, Reinhard states that their camp neighbours "are half idiots[,] the kids are without shame and the mother and grandmother are incapable of doing the smallest thing." 18 This degree of angst is missing in the English translations. Though Helma's motives might have been geared towards portraying her husband in a more 'neighbourly' light, I would argue that more likely she felt that the subject matter had been adequately

${ }^{18}$ Reinhard and Helma to Elfriede Kroll October 24, 1953, German Edition, Book 1 pp.41-42. 
addressed. Along these lines, Helma removes several letters which describe the lack of cleanliness and tidiness in the family's living quarters. She performs "incessant cleaning" and has difficulty doing the laundry; as a result, she sends her family's washing to her mother. ${ }^{19}$ Similarly, Helma describes the disorder of living in transit. As parcels arrive, although she is relieved at their appearance, their physical volume creates havoc. She wonders

where [she] will put all the things. The last spaces in the cupboards and under the beds have been filled. Now I am hoping for the wood box and then again organizing. Packing! Tidiness hurrah! Where did I unpack it? Is it [lying] around? Can't find it...swearing, settle down...it requires a little humour. ${ }^{20}$

Should the above passages have been included, it would have made an excellent visual image to further illustrate the reality of the camp conditions. 'Practical matters,' such as laundry and shelf space, are 'ordinary,' visceral experiences to which a lay person is able to relate. For many Canadians, the Krolls' life at camp-particularly as it relates to space - would be an abstract and ungraspable existence; 'negligible' or 'repetitive' details provide concrete examples of what a modern audience can understand, and thus facilitate a more comprehensive and deeply-rooted understanding of just how dismal the Krolls' conditions were. Though the English translations certainly portray difficulty in the camps, they deprive their readers of the 'full experience.' Perhaps Helma remembers these instances well enough, but for her audience who has not been there, without such thorough descriptions, it is difficult to imagine 'what it was really like.' Again, this begets the question as to what message Helma intended to communicate in her presentation of the letters. Repetition or lack thereof highlights specific themes; seemingly, Helma felt

\footnotetext{
${ }^{19}$ Helma Kroll to Eleonore Scholz. Oct. 29 1953, German Edition, Book 1 p.45.

${ }^{20}$ Helma Kroll to Eleonore Scholz. November 15, 1953, German Edition, Book 1 pp.48-49.
} 
that the audience had been adequately exposed to camp conditions, and in addition, felt that Reinhard's technical work was perhaps not directly relevant to the 'plot line.'

It is important to differentiate between the two types of editing which Helma performed: the removal of complete letters, as opposed to the excision of certain passages. When specific excerpts are edited out, this indicates a deliberate choice in their exclusion, thus, explanations of what Helma deemed 'unimportant' or 'undesirable' to include are much easier to explore. On the opposite end of the spectrum, Helma takes out letters in their entirety. In this circumstance, albeit there are 'repetitive' segments, 'new' ideas are also lost in the process. Even if not an 'event' per se, some of the thoughts and themes presented are significant. Plausibly, this loss is incidental, as there is other evidence to suggest that Helma's transcription may occasionally have fallen victim to human carelessness. For example, some of the letters were transcribed with the wrong date: there were five letters which I had believed to be missing from the English collection only to discover that, once translated, they were in the English volume, misdated. There can be no conceivable motive for this alteration other than a simple mistake. It had little effect upon my reading because the dates were skewed by only several days; nonetheless, it produces the doubt that such lapses may have materialized elsewhere. It is altogether plausible that certain passages faced a similar fate in the editing process, thus evoking the question that if not edited out with intent, what other exclusions have occurred due to human error as opposed to purposeful omission?

Helma chose to completely remove the letter in which Reinhard complains about their neighbours. This subject prominently figures in the correspondence, and admittedly, due to its reoccurring appearance throughout the English translations, could understandably be deemed 'repetitive.' However, even if one were to prescribe to such a 
theory in which 'repetitive' material was eliminated (obviously, I would argue that no matter how repetitive, for purposes of analysis, all passages hold value and hence should be retained), in the process of extracting such 'redundant' material, an extremely significant piece is also lost. In a direct and unequivocal declaration of the family's priorities and actions, Reinhard writes:

The family must in no event be separated. Gerd would especially suffer since there is a very nice development which would be broken. That is our standpoint that under all circumstances, even personal suffering, must be considered. ${ }^{21}$

While such a sentiment might seem obvious to Helma, although it is alluded to in the English translation, this sort of direct statement is missing. Once read in this form, it fits like a missing puzzle piece. It makes the Krolls' subsequent decisions logical, particularly in light of the Canadian employment options (listed in outside sources): Reinhard could have pursued work on his own, and brought his family to Canada later. With regards to Reinhard working alone in Northern Canada, Helma orally states that: "We were afraid of any separation from the children or the husband. It would maybe have been much, much easier if my husband had come first and I stayed, the same like Hundreisers did it, but I didn't want to be separated from my husband. ${ }^{, 22}$ Although we hear this statement from Helma, it is much different from seeing it in her husband's contemporary writing. Perhaps from Helma's perspective, the role and opinions of individual personalities were not as important as the decisions made by the family unit, thus it would not be vital to stress what particular members (Reinhard) of the entity were thinking, for the representative thought or action is assumed to embody the mindset of the whole. However, for a

\footnotetext{
${ }^{21}$ Reinhard and Helma to Elfriede Kroll, October 24, 1953, German Edition, Book 1 pp.41-42.

${ }^{22}$ Interview with Helma Kroll, August 20, 2005, p.17
} 
gendered analysis in particular, who felt what and held which attitude, is particularly telling for such evidence can point one to different conclusions.

We know from the English translation that the Krolls chose to stay together as a family. What is not clear from the edited collection, however, is that there was any discussion of other alternatives. The latter omission seems to fit into Helma's editing pattern: she appears to deliberately strike out references to the 'uneventualities' -or events which were never realized. A strong case for such an observation comes from several instances in which the Krolls were considering their 'options' while in the transit camp. Helma removed four consecutive letters written during this period which explored alternatives to Canadian immigration. In the English translation, Helma's 2001 commentary only briefly mentions that at one point, the Krolls thought about remaining in West Germany. She states,

All this time we were toying with the idea of getting refuge at the forestry in Winnifeld...Omi Kroll's relatives were living there. During their visit in [Winnifeld] they asked and were pleading for us to have a chance to live there until we could go to Canada. It was a very nice thought, but it had some difficult realities... ${ }^{23}$

Though Helma explains what 'happened,' this overview does not adequately represent the conflict which this idea appears to have produced. It is the subject of several original letters between the Krolls and Reinhard's parents; Helma and Reinhard had originally asked his parents to look into the possibility, but for various reasons, they changed their minds. Subsequently, there are several passages of profuse apologies and explanations for the younger Krolls' final decision. ${ }^{24} \mathrm{~A}$ brief summary does not capture the interactions between the two parties, nor does it illustrate Helma and Reinhard's decision making-

\footnotetext{
${ }^{23}$ Helma's Commentary 2001, English Edition, Book 1 p. 26.

${ }^{24}$ See for example, letters dated September 12, 1953 German Edition, Book 1 pp.32-33; October 24, 1953 German Edition, Book 1 pp.41-43; October 25, 1953 German Edition, Book 1 p.43.
} 
process (or even the fact that there was a decision to be had). In addition, the translation's sparse account of this episode causes the reader to be slightly disoriented when coming across brief references to Winnifeld in the rest of the English translation; upon reading the passages in the original letters, the formerly obscure references make sense.

During the same period, the Krolls also toyed with other alternatives. At one point, they considered a temporary move to Canada, "with the thought of returning [to West Germany] when there [was] room. ${ }^{, 25}$ In reality, this is what many of their compatriots were also thinking, for many went to Canada with the intention of return; evidently, a permanent move Canada was not the sole recourse. ${ }^{26}$ Similarly, the original letters present the possibility of emigration to the United States, or at least the willingness to seek out this latter option, which again conforms historically to the overall choice of most postwar immigrants. ${ }^{27}$ Even though these events never transpired and were not explored to a great extent in the original collection, it is important that they are acknowledged. As the letters are presented in English, one is under the false impression that permanent settlement in Canada was the Krolls' only aspiration. Though it arguably was the most viable possibility, the Krolls would undoubtedly have gone elsewhere if the

\footnotetext{
${ }^{25}$ Reinhard and Helma to Elfriede Kroll, 28 October 1953, German Edition, Book 1 pp.44-45.

${ }^{26}$ Gerald Bassler states that nearly $60 \%$ of Canada's ethnic German immigrants in the 1950 s came 'on condition;' $1 / 3$ intended for their settlement to be permanent. Nonetheless, Ronald Schmalz contends that those who left Canada after immigration were few. Between 1951 and 1957, they numbered 7.6\%; smaller than the number leaving the United States or Australia. Needless to say, however, in 1957 when the German economy picked up and the Canadian economy suffered, this number increased. Gerhard Bassler, "Germans," Encyclopedia of Canada's Peoples Paul Robert Magocsi, editor. (Toronto: Published for the Multicultural History Society of Ontario by the University of Toronto Press, 1999), 597. Ronald E. Schmalz, "Former Enemies Come to Canada: Ottawa and the Postwar German Immigration Boom, 19511957." Dissertation (Ottawa: University of Ottawa, 2000), p.173.

${ }^{27} 47 \%$ of German emigrants wanted to go the United States, compared to $20 \%$ to Canada and $10 \%$ to Australia. Wolfgang Friedmann, German Immigration into Canada. Contemporary Affairs-No.23. (Toronto: The Ryerson Press, 1951), p.20. Many Germans thought that Canada was the equivalent to America. Alexander Freund, "Immigrants' Identities: The Narratives of a German-Canadian Migration," $A$ Chorus of Different Voices: German-Canadian Identities. Angelika E. Sauer and Matthias Zimmer, eds. (New York: Peter Lang, 1998), 195.
} 
opportunity had presented itself. Even in the oral testimony, alternatives to Canada probably would have been glossed over had Beate not mentioned that the Krolls' visa applications were denied by the United States beforehand. ${ }^{28}$ In the oral testimony, but more particularly the letter collection, there appears to be an attempt to 'stream line' the narrative. In our examination of why Helma edited out these passages, we can speculate that perhaps she did not see such information as pertinent to her family's immigration. She may not have seen the significance of the decision process - the options which the Krolls chose to pass up-which notably speak to their agency. For her, the end result of their story appears to take precedence. Like much of mainstream society, Helma might view history in terms of what transpired, as opposed to 'non-events.' She might perceive these retrospective 'possibilities' as asides which ultimately led nowhere and therefore are not appropriate for inclusion. Alternatively, perhaps Helma feels that this would skew the image of the family's migration; if the Krolls contemplated options other than permanent settlement to Canada, does this mar their immigration story? Does it suggest that they think less of Canada? What version of the Krolls' story is Helma comfortable with?

Based on the limited number of juxtaposed letters, Helma's translations appear to be accurate. That being said, there are a few noteworthy deletions which warrant discussion. Thus far, Helma's editing has been discussed in context of repetition, detail, 'insignificance' and non-realized events; the last 'category' of editing out which this appendix intends to address was alluded to in the previous paragraph: that which might compromise the author's self-identity or the image of their experience which they wish to portray. Evidence suggests that on the whole, Helma was very 'honest' with her

\footnotetext{
${ }^{28}$ Interview with Helma Kroll and Beate Myhill, June 9, 2005. p.14
} 
translation. She leaves in events which she herself would likely prefer to forget (for example, the rape) and she includes incidents which she acknowledges are unacceptable by today's standards. For instance, in one letter, Helma admits to having left the couple's infant in the car throughout the day. In her commentary she writes: "As I am translating this-how could we!-For sure today it would be unthinkable-but what could we have done?"29 Helma knows that this excerpt will likely produce a degree of negative judgment from her audience, yet she includes it. In cases such as this, Helma seems to hide little and tell the story 'as it was.' Nonetheless, a letter dated October 4, 1954, suggests that just like memory, the editing process is also selective. In this lengthy letter, it is evident that censorship extended beyond that information which could be perceivably deemed repetitive or insignificant. When the Krolls first arrive in Canada and are on the train, Helma neglects to transcribe: "A mulatto woman, very correct, smiled at the children. Now the ice was broken. $" 30$ Though the evidence does not indicate that this was intended as a derogatory comment, it is entirely possible that Helma worried about how such a comment might be received amid modern society's notion of political correctness and its heightened sense of discrimination. ${ }^{31}$ Likewise Helma appears to have downplayed the fact that alternatives to permanent Canadian immigration were considered. The result is a smoother narrative which portrays the Krolls as entirely Canada-bound.

Nonetheless, for the most part the translations suggest that during the editing process few purposeful omissions were motivated by self-interest. Rather, on the whole, the evidence points to an editing method which was 'innocent.' Given that eight letters

\footnotetext{
${ }^{29}$ Helma Kroll to to Eleonore Scholz and Richard and Elfriede Kroll. April 29, 1956. Book 2, p.65

${ }^{30}$ Helma and Kroll to Eleonore Scholz and Richard and Elfriede Kroll. October 4, 1954. German Edition Book 1, pp.103-108; English Edition, Book 1 pp.59-62.

${ }^{31}$ When Inge Harris translated, she compared this sentence to her own experience: she remembered how surprised she was to see her first black person.
} 
were translated directly, one would expect that if a concentrated effort were to be made to direct the Krolls' experience in a specific light, it would have been done in a much more thorough (and apparent) manner. Stemming from this conclusion-that omissions on the whole were not performed with a hidden agenda - we are ultimately brought back to the central issue concerning this collection: Helma's perception of what was 'important.'

Here, a worn cliché seems to perfectly make my point: just as 'beauty is in the eye of the beholder,' so is the notion of significance. It never occurred to Helma when she wrote the memoirs, transcribed, or translated the letters that they would one day be analyzed by an academic audience; rather, the collection was solely meant to preserve her family's history for her children and grandchildren. Though one may criticize how Helma chose to present the letters in their English edition, her rationale must be placed in this context. She included what she would find interesting and worthy of attention. Repetition and the presence of non-events would be unnecessary.

Although there are certainly discrepancies between the German and English Kroll letters, on the whole, the evidence points to a relatively forthright transcription and translation. True to Helma's testimony, it seems as though no major 'events' were left out, and that the integrity of the original letters - their sentiment, voice, and characterwas preserved. While there may be material that got 'lost in translation' and some nuances that were muted, the central story, aided (and reflected) by oral testimony, was transmitted. 


\section{Bibliography}

\section{Primary Sources:}

\section{Manuscripts}

The Kroll Letter Collection (English): Volume I and Volume II, translated 2001 by Helma Kroll. Centre for Canadian-Russian Relations, Carleton University.

The Kroll Letter Collection (German): Volume I and Volume II, transcribed 1991 by Helma Kroll. Centre for Canadian-Russian Relations, Carleton University.

\section{Interviews:}

Interview by Meaghan Harris with Helma Kroll and Beate Myhill, June 8, 2005.

Interview by Meaghan Harris with Helma Kroll and Beate Myhill, Aug 9, 2005.

Interview by Meaghan Harris with Helma Kroll and Beate Myhill, June 20, 2005.

\section{Government Archives (Held at LAC)}

RG 26 Vol .115 3-24-18

RG 26 Vol .115 3-24-19

RG 26 Vol .115 3-24-20

RG 26 Col. 115 3-24-18

RG 26 Vol. 127 3-33-13.

RG 76 Vol. $800547-1$ pt. 2

RG 76 Vol. $800547-1$ pt. 3

RG 76 Vol. 801 547-5-551 pt. 1.

RG 76 Vol. 821, File 552-1-551 pt. 1

RG 76 Vol. 868 556-1-551

RG 76 Vol. 876 560-2-551

RG 76 Vol. 932 Ch.1 Index

RG 76 Vol. 935 Binder \#10

RG 76 Vol. 935 Binder \#11

RG 76 Vol. 948 SF-C-1-1 pt.1

\section{Government Publications:}

Canada. Department of Citizenship and Immigration. Canadian Immigration: An Outline of Developments in the Post-War Period. Ottawa: Department of Citizenship and Immigration, 1957. 
Canada. Department of Citizenship and Immigration. 1954-55 Annual Report Department of Citizenship and Immigration. Ottawa: Queen's Printer and Controller of Stationary, 1955.

Canada: Department of Manpower and Immigration. The Immigration Program: A Report of the Canadian Immigration and Population Study. Ottawa: Department of Manpower and Immigration, 1974.

Canada. Economics and Research Branch, Department of Labour. The Migration of Professional Workers Into and Out of Canada 1946-1960. Bulletin No.11, October 1961

Parai, Louis. Immigration and Emigration of Professional and Skilled Manpower during the Post-war Period. Special Study No.1 Economic Council of Canada, June 1965. Ottawa: Queen's Printer, 1965.

Canada. Royal Commission on Bilingualism and Biculturalism. The Cultural Contributions of the Other Ethnic Groups. Ottawa: Queen's Printer, 1970.

Tremblay, Rene, Minister of Citizenship and Immigration. "The Contribution of Immigrants to the Canadian Economy" (A translation summary of an address by the Honourable Rene Tremblay, Minister of Citizenship and Immigration, the Richelieu Club, Hull, PQ, Tuesday, March 17, 1964\}, Studies and Documents on Immigration and Integration in Canada. Montreal: Jewish Immigrant Aid Service of Canada, 8 June 1964, 3-39.

\section{Published Primary Sources}

\section{Newspaper Articles}

Allen, Ralph. "The Untroublesome Canadians," MacLean's 77(1964), 19-21, 50, 52-3.

Felming, Joseph. European Edition of Stars and Stripes, Wednesday, March 4, 1953, 2

Green, O.M."Germany's Human Flood That Never Stops" The Globe and Mail, March 9, $1953,6$.

Lehm, Richard. "Settling The East Zone Refugee The Task Of A West German Reception Camp," The Times, Aug 20, 1953, F, 7.

Margolin, Nathan J. "Refugees Flood Berlin as Reds Tighten Grip." Stars and Stripes. (No date visible, but sent to Ottawa March 23, 1953) (RG 76 Vol 801 547-5-551 pt.1.)

Sullivan, Walter. "Drifters Among East Zone Refugees Pose Security Problem for Berlin; Some Are Known Communist Agents and Others Fled in Panic -- Political Fugitives Are Being Flown to West Germany," The New York Times. Jan 30, 1953, 5.

Author uncited. "Curtain Flood Overflows 85 Berlin Camps" in European Edition of The Stars and Strips. March 4, 1953, 1, 16. 
Author uncited. "Eastern Refugees Pour Into Berlin; Western Officials Report Total Has Now Reached 200,000 -- Soviet Zone Curbs Travel" Special to Tram, The New York Times. Jul 30, 1952, F, 1,4.

Author uncited. "German Refugees Set New Record; 2,600 Registered in Berlin in One Day, With Many More Awaiting Final Approval ."Special to The New York Times. Feb 3, 1953,6 .

Author uncited. AFRF News Bulletin, New York. "They Chose Freedom." Display Ad 5, New York Times. Aug 8, 1955, 6.

Author uncited. "Gallop Poll: Bitterness Against Germans Waning Among Canadians" Montreal Star. November 15 1952. (no page listed, found in RG 76 Vol. 821, File 552-1551 pt. 1.

Merritt, Anna and Richard Merritt._Public Opinion in Semisovereign Germany: The HICOG Surveys, 1945-49. Urbana: University of Illinois Press, 1980

Merritt, Anna J. and Richard L. Merritt., with a foreword by Frederick W.

Williams. Public Opinion in Occupied Germany: The OMGUS Surveys 1945-49. Urbana: University of Illinois Press, 1979.

\section{Memoirs/ First-hand Testimony}

Bruce, Jean. After the War. Ontario: Fitzhenry and Whiteside, 1982.

Broadfoot, Barry. The Immigrant Years: From Europe to Canada 1945-67. Vancouver: Douglas \& McIntyre, 1986

Cunliffe, Harry. "The Liberalization of Immigration Policy from 1945 to 1956: An Insider's View" In From Breaking Ground: The 1956 Hungarian Refugee Movement to Canada. Edited by Robert H. Keyserlingk, 13-23. North York: York Lanes Press, 1993.

Grossman, Ibolya. An Ordinary Woman in Extraordinary Times. Toronto: The Multicultural History Society of Ontario, 1990.

Hegi, Ursula. Tearing the Silence New York: Simon and Schuster, 1996.

Hoffman, Eva._Lost in Translation. New York: Penguin, 1989.

Klassen, Pamela. Going by the Moon and the Stars: Stories of two Russian Mennonite Women. Waterloo: Wilfrid Laurier University Press, 1994.

Ritter, Maria. Return to Dresden. Jackson: University of Mississippi, 2004. 


\section{Secondary Sources}

\section{A. Unpublished Sources}

Forchner, Gisela. "Growing Up Canadian: Twelve Case Studies of German Immigrant Families in Alberta." PhD thesis. University of Alberta, 1983

Freund, Alexander. "Identity in Immigration: Self-Conceptualization and Myth in the narratives of German Immigrant Women in Vancouver, BC, 1950-1960." MA paper, Simon Fraser University, 1994.

Gumpp, Ruth. "Ethnicity and Assimilation. German Postwar Immigrants in Vancouver, 1945-1970.” PhD thesis, University of British Columbia, 1989.

Imort, Michael. "Forestopia: The use of the forest landscape in naturalizing National Socialist ideologies of Volk, race, and Lebensraum, 1918-1945 (Germany)." PhD thesis, Queens University, 2000.

Nelson, Arvid Robert . "Acid rain and romanticism: East German forestry, 1945-1989" PhD thesis, Yale University, 1998.

Schmalz, Ronald E. "Former Enemies Come to Canada: Ottawa and the Postwar German Immigration Boom, 1951-1957." PhD thesis, University of Ottawa, 2000.

Walsh, John C. "Re-thinking Ethnic Boundaries: The Negotiation of German-Canadian Ethnic Identities in Ottawa, 1945-75." MA thesis, University of Ottawa, 1996.

\section{Articles:}

Anderson, Kathryn and Dana C. Jack. "Learning to Listen: Interview Techniques and Analyses." In Women's Words: The Feminist Practice of Oral History. Edited by Sherna Berger Gluck and Daphne Patai, 11-26. New York: Routledge, 1991.

Barber, Marilyn. "Hearing Women's Voices: Female Migration to Canada in the Early Twentieth Century." Oral History, 3, no.1 (Spring 2005):68-76.

Bassler, Gerhard P. "German-Canadian Identity in Historical Perspective." In A Chorus of Different Voices. Edited by Angelika E. Sauer and Matthias Zimmer, 86-98. New York: Peter Lang, 1998.

Basser, Gerhard. "Germans.” Encyclopedia of Canada's Peoples. Edited by Paul Robert Magocsi. Toronto: Published for the Multicultural History Society of Ontario by the University of Toronto Press, 1999.

Bassler, Gerhard. "Problems and Perspectives in German-Canadian Historiography." Annals: German-Canadian Studies. 5 (1985): 1-19. 
Bessel, Richard, "Police of a 'New Type'? Police and Society in East Germany after 1945." German History 10(1992): 290-301.

Boss, Pauline Grossenbacher. "The Experience of Immigration For the Mother Left Behind: The Use of Qualitative Feminist Strategies to Analyze Letters from My Swiss Grandmother to My Father." Marriage and Family Review, 19(1993): 365-78.

Boyd, Monica, "The Status of Immigrant Women in Canada," Canadian Review of Sociology and Anthropology 12 (1975), 406-416.

Conrad, Margaret. "Recording Angels: The Private Chronicles of Women from the Maritime Provinces of Canada, 1750-1950." Ottawa: CRIA/ICRAF, 1982.

Conrad, Margaret "Sundays Always Make Me Think of Home': Time and Place in Canadian Women's History." In Not Just Pin Money: Selected Essays On The History Of Women's Work in British Columbia. Edited by Barbara K. Latham and Robert J. Pazdro, 1-16. Victoria: Camosun College, 1984.

Cunliffe, Harry. "The Liberalization of Immigration Policy from 1945 to 1956: An Insider's View." Breaking Ground: The 1956 Hungarian Refugee Movement to Canada. Edited by Robert H. Keyserlingk, 12-23. North York: York Lanes Press, 1993.

Dehaan, Kathleen A. "“Wooden Shoes and Mantle Clocks': Letter Writing as a Rhetorical Forum for the Transforming Immigrant Identity." In Alternative Rhetorics: Challenges to the Rhetorical Tradition. Edited by Laura Gray-Rosendale, Sibylle Gruber, 53-76. Albany: State University of New York Press, 2001.

Dirks, Gerald E. "Canada and Immigration: International and Domestic Considerations in the Decade Preceding the 1956 Hungarian Exodus." In Breaking Ground: The 1956 Hungarian Refugee Movement to Canada. Edited by Robert H. Keyserlingk, 3-11. North York: York Lanes, 1993.

Draper, Paula J. "Surviving Their Survival: Women, Memory, and the Holocaust." In Sisters or strangers? Immigrant, Ethnic and Racialized Women in Canadian History. Edited by Marlene Epp, Franca Iacovetta, Frances Swyripa, 399-414. Toronto: University of Toronto Press, 2003.

Dreisziger, N.F. "The Refugee Experience in Canada and the Evolution of the HungarianCanadian Community" in Breaking Ground: The 1956 Hungarian Refugee Movement to Canada. Edited by R.H. Keyserlingk (North York: York Lane Press, York University, 1993), pp. 65-86.

Epp, Marlene. "The Memory of Violence: Soviet and East European Mennonite Refugees and Rape in the Second World War.' Journal of Women's History 9, no.1 (1997): 58-87. 
Epp, Marlene. "The Semiotics of Zwieback: Feasast and Famine in the Narratives of Mennonite Refugee Women," Sisters or strangers? Immigrant, Ethnic and Racialized Women in Canadian History. Edited by Marlene Epp, Franca Iacovetta and Frances Swyripa, 314-340. Toronto: University of Toronto Press, 2003.

Espin, Oliva M. "Roots Uprooted: The Psychological Impact of Historical/Political Dislocation." In Refugee Women and Their Mental Health: Shattered Societies, Shattered Lives. Edited by Ellen Cole, Oliva M. Espin, Esther D. Rothblum, 9-20. New York: Haworth, 1992.

Finkel, Alvin. "Canadian Immigration Policy and the Cold War: 1945-1980" Journal of Canadian Studies. 21 (1986): 53-69.

Fitzpatrick, David. "'Oceans of Consolation' Letters and Irish Immigration to Australasia." In Visible Immigrants. Edited by Eric Richards, Richard Reid, David Fitzpatrick, 47-87. Canberra: Department of History and the Centre for Immigration and Multicultural Studies, Research School of Social Sciences, Australian National University.

Freund, Alexander. "Immigrants' Identities: The Narratives of a German-Canadian Migration." In A Chorus of Different Voices: German-Canadian Identities. Edited by Angelika E. Sauer and Matthias Zimmer, 187-208. New York: Peter Lang, 1998.

Freund, Alexander and Laura Quilici “Exploring Myths in Women's Narratives: Italian and German Immigration Women in Vancouver, 1947-1961." BC Studies, 105-6 (Spring/Summer 1995):159-182.

Froeschle, Hartmut. "The History and Heritage of German Immigration to Canada." Canadiana Germanica-A Journal for German-Canadian Studies and News Bulletin of the German-Canadian Historical Association and the Historical Society of Mecklenburg Upper Canada Inc. Occasional Papers Beihefte. No. 3 (1982).

Fulbrook, Mary "Ossis and Wessis: the Creation of Two German Societies." In German History since 1800. Edited by Mary Fulbrook, assistant editor, John Breuilly, 411-431. London: Arnold, 1997.

Freund, Alexander. "Immigrants Identities: The Narratives of a German-Canadian Migration." In A Chorus of Different Voices: German-Canadian Identities. Edited by Angelika E. Sauer and Matthias Zimmer, 187-208. New York: Peter Lang, 1998.

Fry, Amelia R. "Suffragist Alice Paul's Memoirs: Pros and Cons of Oral History." Frontiers, 2 (1977): 82-86.

Gerber, David. "Epistolary Ethics: Personal Correspondence and the Culture of Emigration in the Nineteenth Century." Journal of American Ethnic History. 19, no.4 (Summer 2000): 3-23. 
Gerber, David A. "Epistolary Masquerades: Acts of Deceiving and Withholding in Immigrant Letters," in Letters Across Borders: The Epistolary Practices of International Migrants. Edited by Bruce S. Elliot, David A. Gerber and Suzanne Sinke. New York: Palgrave, 2006 (forthcoming).

Gerber, David A. "Ethnic Identification and the Project of Individual Identity: The Life of Mary Ann Wodrow Archbald (1768-1840) of Little Cumbrae Island, Scotland and Auriesville, New York." Immigrants and Minorities. 17(1998): 1-22.

Gerber, David A. "Forming a Transnational Narrative: New Perspectives on European Migrations to the United States." The History Teacher 35, no.1 (2001):61-78.

Gerber, David A. "The Immigrant Letter between Positivism and Populism: The Uses of Immigrant Personal Correspondence in Twentieth-Century American Scholarship," The Journal of American Ethnic History. 16, no.4 (Summer 1997): 3-31.

Gitelson, Joshua. "Populox: The Suburban Cuisine of the 1950s." Journal of American Culture 15(1992): 73-78.

Gluck, Sherna. "What's so Special About Women? Women's Oral History" Frontiers. 2 (1977): 3-13.

Gluck, Sherna Berger. "What's so special about women? Women's oral history," in Women's oral history: the Frontiers reader. Edited by Susan H. Armitage, Patricia Hart and Karen Weathermon, 3-26. Lincoln: University of Nebraska Press, 2002.

Grant, Gail. "That Was a Woman's Satisfaction: The Significance of Life History for Woman-Centred Research," Canadian Oral History Association, 11(1991): 29-38.

Grossman, Atina. "A Question of Silence: The Rape of German Women by Occupation Soldiers.” October, 72 (Spring, 1995): 42-63.

Helbich, Wolfgang and Walter D. Kamphoefner. "How Representative Are Emigrant Letters? An Exploration of the German Case." In Letters Across Borders: The Epistolary Practices of International Migrants. Bruce S. Elliot, David A. Gerber and Suzanne Sinke, eds. New York: Palgrave, 2006 (forthcoming).

Iacovetta, Franca and Valerie J. Korinek. "Jello-O Salads, One-Stop Shopping, and Maria the Homemaker: The Gender Politics of Food." In Sisters or strangers? Immigrant, Ethnic and Racialized Women in Canadian History. Edited by Marlene Epp, Franca Iacovetta, Frances Swyripa, 190-230. Toronto: University of Toronto Press, 2003.

Iacovetta, Franca. "Making Model Citizens: Gender; Corrupted Democracy, and Immigrant and Refugee Reception Work in Cold War Canada," In Whose National Security? Canadian State Surveillance and the Creation of Enemies. Edited by Gary Kinsman, Dieter K. Buse, Mercedes Steedman, eds. Toronto: Between the Lines, 2000. 
Iacovetta, Franca. "Making 'New Canadians': Social Workers, Women and the Reshaping of Immigrant Families." In Gender Conflicts: New Essays in Women's History. Edited by Franca Iacovetta and Mariana Valverde, 261-303. Toronto: University of Toronto Press, 1992.

Iacovetta, Franca. "Recipes for Democracy? Gender, Family and Making." Canadian Woman Studies, 20 (2000):12-21.

Iacovetta, Franca. "Remaking Their Lives Women Immigrants, Survivors and Refugees," In $A$ Diversity of Women: Ontario, 1945-1980. Edited by Joy Parr, 135-167. Toronto: University of Toronto, 1995.

Ingimundarson, Valur. "Cold War Misperceptions: The Communist and Western Responses to the East German Refugee Crisis in 1953." Journal of Contemporary History, 29(1994): 463-481.

Langfield, Michelle and Pam Maclean, "But Pineapple I'm Still A Bit Way of': Sensory Memories of Jewish Women who Migrated to Australia as Children, 1938-9," Speaking to Immigrants: Oral Testimony and the History of Australian Migration. Edited by A. James Hammerton and Eric Richards, Canberra: History Program and Centre for Immigration and Multicultural Studies, Rsearch School of Social Sciences, The Australian National University, 2002. 83-109.

Lewis, Gertrud Jaron."The German Woman Immigrant in Northeastern Ontario." Annals: German-Canadian Studies 5(1983): 143-166.

Lindenberge, Thomas. "Creating State Socialist Governance: The Case of the Deutsche Volkspolizei," in Dictatorship as Experience Towards a Socio-Cultural History of the GDR. Edited by Konrad H. Jarausch. 126-141. New York: Berghahn Books, 1999.

Lorenzkowski, Barbara. "Making Music - Building Bridges: German-Canadian Identities in the Nation's Capital, 1958-1999," in Construire une capitale Ottawa Making a Capital. Edited by Jeff Keshen and Nicole St.Onge. (Ottawa: University of Ottawa Press, 2001): 307-330.

Lucik, Lubomyr Y.““This Should Never Be Spoken or Quoted Publicly': Canada's Ukrainians and Their Encounter with the DPs" in Canada's Ukrainians: Negotiating an Identity. Edited by Stella Hryniuk \& Lubomyr Luciuk (Toronto: University of Toronto Press, 1991), 102-122.

McCarthy, Angela. "Personal Letters, Oral Testimony and Scottish Migration to New Zealand in the 1950s: The Case of Lorna Carter," Immigrants and Minorities, 23 (2005): 59-79. 
McCormack, Ross "Networks Among British Immigrants and Accommodation to Canadian Society: Winnipeg, 1900-1914," in Immigration in Canada: Historical Perspectives. Edited by Gerald Tulchinsky, 203-222. Toronto : Copp Clark Longman, 1994.

Minister, Kristina. "A Feminist Frame for the Oral History Review," In Women's Words: The Feminist Practice of Oral History. Edited by Sherna Berger Gluck and Daphne Patai, 27-41. New York: Routledge, 1991.

Oikawa, Mona. "Cartographies of Violence: Women, Memory, and the Subject(s) of the "Internment,"' In Race, Space and the Law: Unmapping a White Settler Society. Edited by Sherene H. Razack, 71-98. Toronto: Between the Lines, 2002.

Palmer, Howard. "Reluctant Hosts: Anglo-Canadian Views of Multiculturalism in the Twentieth Century," in Immigration in Canada. Edited by Gerald Tulchinsky, 297-333. Toronto: Copp Clark Longman, 1995.

Pence, Katherine. "The Myth of a Suspended Present: Prosperity's Painful Shadow in 1950s East Germany." In Pain and Prosperity: Reconsidering Twentieth Century German History. Edited by Paul Betts and Greg Eghigian, eds., 137-159. Stanford: Stanford University Press, 2003.

Rawlyk, G.A. “Canada's Immigration Policy, 1945-1962," Dalhousie Review, 42(1962): 287-300.

Roesler, Jörg "The Black Market in Post-war Berlin and the Methods Used to Counteract it." German History 7, no.1 (1989): 92-107.

Ross, Corey "Before the Wall: East Germans, Communist Authority, and the Mass Exodus to the West," The Historical Journal, 45 (2002): 459-480.

Sangster, Joan. "Telling Our Stories: Feminist Debates and the Use of Oral History," in Rethinking Canada: The Promise of Women's History. Edited by Veronica Strong-Boag, Mona Gleason, Adele Perry, $4^{\text {th }}$ ed., 220-334. Toronto: Oxford University Press, 2002.

Stilling, Niels Peter. "The Significance of the Private Letter in Immigration History." The Bridge: Journal of the Danish American Heritage Society. 15(1992): 35-50.

Strobel, Margaret. "Doing Oral History As an Outsider." Frontiers, 2(1977): 68-72.

Stebelsky, Ihor. "The Resettlement of Ukrainian Refugees in Canada After the Second World War" in Canada's Ukrainians: Negotiating an Identity. Edited by Stella Hryniuk \& Lubomyr Luciuk. Toronto: University of Toronto Press, 1991. pp.123-155.

Stuart, Mary. "You're a Big Girl Now; Subjectives, Feminism, and Oral History," Oral History, (Autumn 1994): 55-63. 
Sauer, Angelika E. "Christian Charity, Government Policy and German Immigration to Canada and Australia, 1947 to 1952," in Immigration and Ethnicity in Canada: selected proceedings of the 22nd Annual Conference of the Association for Canadian Studies held at the Université du Québec à Montréal, 7-9 June 1995. Edited by Anne Laperrière, Varpu Lindström, and Tamara Palmer Seiler, 159-180. Montréal: Association for Canadian Studies, 1996.

Sauer, Angelika E. "The 'Ideal German Canadian': Politics, Academics and the Historiographical Construction of German-Canadian Identity" in $A$ Chorus of Different Voices: German-Canadian Identities. Edited by Angelika E. Sauer and Matthias Zimmer, 227-244. New York: Peter Lang, 1998.

Sauer, Angelika E. "A Matter of Domestic Policy? Canadian Immigration Policy and the Admission of Germans, 1945-50," Canadian Historical Review. 74(1993): 226-263.

Thomson, Alistair. "Moving Stories: Oral History and Migration Studies." Oral History, 27, no.1 (Spring 1999): 24-37.

Tröger, Anne Marie. "Between Rape and Prostitution: Survival Strategies and Chances of Emancipation for Berlin Women After World War II," translated by Joan Reutershan, in Women in Culture and Politics: A Century for Change. Edited by Judith Friedlander et al., 97-117. Bloomington: Indiana University Press, 1986.

Werner, Hans. "'Kinder, Küche, kirche': Re-creating Identity in Postwar Canada," In $A$ Chorus of Different Voices: German-Canadian Identities. Edited by Angelika E. Sauer and Matthias Zimmer, 209-222. New York: Peter Lang, 1998.

Wierling, Dorothee. "The Hitler Youth Generation in the GDR, Insecurities, Ambitions and Dilemnmas" In Dictatorship as Experience Towards a Socio-Cultural History of the GDR. Edited by Konrad H. Jarausch, 308-324. New York: Berghahn Books, 1999.

Wrye, Harriet and Jacqueline Churilla, "Looking Inward, Looking BackwardReminiscence and the Life Review," In Women's Oral History: The Frontiers Reader. Edited by Susan H. Armitage, with Patricia Hart and Karen Weathermon, 145-157. Lincoln: University of Nebraska Press, 2002.

Yung, Judy. "Giving Voice to Chinese American Women," In Women 's Oral History: the Frontiers Reader. Edited by Susan H. Armitage, with Patricia Hart and Karen Weathermon, 87-111. Lincoln: University of Nebraska Press, 2002.

Zybala, Stan. "Canadian Germans and their Integration" Working paper given by Stan Zybala at the National Conference of the Canadian Citizenship Branch, October 1963. Ottawa: Department of Citizenship and Immigration, 1963. 


\section{Books:}

Abella, Irving and Troper, Harold. None is Too Many: Canada and the Jews of Europe 1933-1948. Toronto: Lester \& Orpen Dennys, 1982

Allen, Bruce. Germany East Dissent and Opposition. Montreal: Black Rose, 1991.

Avery, Donald H. Reluctant Host: Canada's Response to Immigrant Workers, 1896-1994. Toronto: McClelland \& Stewart, 1995.

Edited with Introduction by Samuel L. Baily and Franco Ramella. One Family, Two Worlds: An Italian Family's Correspondence Across the Atlantic, 1901-1922. Translated by John Lenaghan. New Brunswick: Rutgers University Pres, 1988.

Bodnar, John. The Transplanted: A History of Immigrants in Urban America. Bloomington: Indiana University Press, 1985.

Brinks, Herbert J. ed. Dutch American Voices: Letters from the United States: 1850-1930 Ithaca: Cornell University Press, 1995.

Bruce, Gary. Resistance with the People: Repression and Resistance in Eastern Germany, 1945-55. New York: Rowman \& Littlefield Publishers, 2003.

Burnet, Jean, ed. Looking into My Sister's Eyes: An Exploration in Women's History. Toronto: the Multicultural History Society of Ontario, 1986.

Childs, David. The GDR: Moscow's German Ally. London: University of Nottingham, 1983, edition 1988.

Conrad, Margaret, Toni Laidlaw, and Donna Smyth, eds. No Place Like Home: Diaries and Letters of Nova Scotia Women 177I-1938. Halifax: Formac Publishing Company Limited, 1988.

Danys, Milda. DP Lithuanian Immigration to Canada After the Second World War. Toronto: Multicultural History Society of Ontario, 1986.

Dennis, Mike. The Rise and Fall of the German Democratic Republic 1945-1990. New York: Longman, 2000.

Dirks, Gerald E. Canada's Refugee Policy: Indifference or Opportunism? Montreal: McGill-Queen's University Press, 1977.

Dornberg, John. The Other Germany._New York: Doubleday \& Co. 1968. 
Dreisziger, NF with ML Kovacs, Paul Body, and Bennet Kovrig. Struggle and Hope: the Hungarian-Canadian Experience. Toronto: McClelland and Stewart with the Mutliculturalism Directorate, Dept. of the Secretary of State, and the Canadian Government Publishing Centre, Supply and Services Canada, 1982

Dudden, Faye E. Serving Women: Household Service in Nineteenth-Century America. Middleton: Wesleyan University Press, 1983.

Ecksteins, Modris. Walking Since Daybreak: A Story of Eastern Europe, World War II, and the Heart of Our Century. Toronto: Key Porter Books, 1999.

Elliott, Bruce S. David A. Gerber and Suzanne Sinke, eds. Letters Across Borders: The Epistolary Practices of International Migrant. New York: Palgrave, 2006 (forthcoming).

Epp, Marlene Women Without Men: Mennonite Refugees of the Second World War. Toronto: University of Toronto Press, 2000.

Ets, Marie Hall. Rosa: The Life of An Italian Immigrant. Foreward by Rudolph J. Vecoli. Minneapolis: University of Minnesota Press, 1970.

Fender, Stephen. Sea Changes: British Emigration \& American Literature. Cambridge: University of Cambridge, 1992.

Frevert, Ute. Women in German History From Bourgeois Emancipation to Sexual Liberation. Translated by Stuart McKinnon-Evans in association with Terry Bond and Barbara Norden. New York: St. Martin's Press, 1986.

Fulbrook, Mary. Anatomy of a Dictatorship: Inside the GDR 1949-1989. New York: Oxford University Press, 1995.

Fulbrook Mary. The Divided Nation: A History Of Germany 1918-1990. New York: Oxford University Press, 1992.

Fulbrook, Mary. The Two Germanies, 1945-1990 Problems of Interpretation. London, MacMillan, 1992.

Friedmann, Wolfgang G. German Immigration into Canada. Contemporary AffairsNo.23. Toronto: The Ryerson Press, 1951.

Gabbaccia, Donna R. We Are What We Eat: Ethnic Food and the Making of Americans. Cambridge: Harvard University Press, 1998.

Hawkins, Freda. Canada and Immigration: Public Policy and Public Concern. Montreal: McGill-Queen's University Press, 1972.

Heineman, Elizabeth D. What Difference does a Husband Make? Women and Marital Status in Nazi and Postwar Germany. Berkeley: University of California Press, 1999. 
Helbich, Wolfgang, Walter D. Kamphoefner, Ulrike Sommer, eds. News From the Land of Freedom: German Immigrants Write Home. Susan Carter Vogel, trans. Ithaca: Cornell University Press, 1991.

Helling, Rudolph A., Jack Thiessen, Fritz Wieden, Elizabeth and Kurt Wangenheim, Karl Heeb. A Socio-economic History of German-Canadians: They, Too, Founded Canada, ed. Bernd Hamm. Wiesbaden: F. Steiner, 1984.

Hoerder, Dirk. Creating Societies: Immigrant Lives in Canada. Montreal: McGillQueen's University Press, 1999.

Iacovetta, Franca, Gatekeepers: Reshaping Immigrant and Refugee Lives in Cold War Canada. Toronto: Between the Lines, forthcoming.

Iacovetta, Franca. Such hardworking people: Italian immigrants in postwar Toronto. Montreal: McGill-Queen's University Press, 1992.

Iacovetta, Franca. The Writing of English Canadian Immigrant History. Canada's Ethnic Group Series, Booklet No.22. Ottawa: The Canadian Historical Association, 1997.

Kelley, Ninette and Michael Trebilcock. The Making of the Mosaic: A History of Canadian Immigration Policy. Toronto: University of Toronto, 1998.

Olga Kenyon. 800 Years of Women 's Letters. Boston: Faber and Faber Inc, 1992.

Olga Kenyon, in Women's Voices: Their Lives and Loves Through Two Thousand Years of Letters. London: Constable, 1995.

Knowles, Valerie. Strangers at Our Gates: Canadian Immigration and Immigration Policy, 1540-1990. Toronto: Dundurn Press, 1992.

Kopstein, Jeffrey. The Politics of Economic Decline in East Germany, 1945-1989. Chapel Hill: University of North Carolina Press, 1997.

Korinek, Valerie J. Roughing it in the Suburbs: Reading Chatelaine Magazine in the Fifties and Sixties. Toronto: University of Toronto, 2000.

Krisch, Henry. The German Democratic Republic. Boulder: Westview Press, 1985.

Leibbrandt, Dr. Gottlieb. Little Paradise: The Saga of German Canadians of Waterloo County, Ontario 1800-1975. Kitchener: Allprint, 1980.

Leonhard, William. Child of the Revolution. London: Collins, 1957.

Lindström, Varpu. Defiant Sisters: A Social History of Finnish Immigrant Women in Canada. Beaverton, ON: Aspasia Books, 1987,1992, reprint, 2003. 
Margolian, Howard. Unauthorized Entry: The Truth About Nazi War Criminals in Canada, 1946-1956. Toronto: University of Toronto Press, 2000.

Marrus, Michael. The Unwanted: European Refugees in the $20^{\text {th }}$ Century. New York: Oxford University Press, 1985.

Marques, Domingos and Manuela Marujo. With Hardened Hands: A Pictorial History of Portuguese Immigration to Canada in the 1950s. Etobicoke: New Leaf Publications, 1993.

McCauley, Martin. The German Democratic Republic Since 1945. New York: St. Martin's Press, 1983

McLaughlin, K.M. The Germans in Canada. Ottawa: Canadian Historical Association, 1985.

Kerby A. Miller, Arnold Schrier, Bruce D. Boling, David N. Doyle, eds. and writers. Irish Immigrants in the Land of Canaan: Letters and Memoirs from Colonial and Revolutionary America, 1675-1815. Oxford: Oxford University Press, 2003

Miller, Kerby A. Emigrants and Exiles: Ireland and the Irish Exodus to North America.. Oxford: Oxford University Press, 1985.

Mitic, Trudy Duivenvoorden ed. People in Transition: Reflections on Becoming Canadian. Markham: Fitzhenry \& Whiteside, 2001.

Naimark, Norman N. The Russians in Germany: A History of the Soviet Zone of Occupation, 1945-9. Cambridge: The Belknap Press of Harvard University Press, 1995.

Ostermann, Christian F, ed. with Malcolm Byrne. Uprising in East Germany 1953: the Cold War, the German Question, and the First Major Upheaval Behind the Iron Curtain. [produced in collaboration with The Cold War International History Project at the Woodrow Wilson International Center for Scholars]. New York: Central European University Press, 2001.

Owram, Doug. Born at the Right Time: A History of the Baby-Boom Generation. Toronto: University of Toronto Press, 1996.

Radecki, Henri with Benedykt Heydenkorn. A Member of a Distinguished Family: The Polish Group in Canada. Toronto: McClelland and Stewart; Ottawa: Multiculturalism Program, Dept. of the Secretary of State of Canada, Publishing Centre, Supply and Services Canada, 1976.

Richmond, Anthony H. Post-war Immigrants in Canada. Toronto: University of Toronto, 1967. 
Richmond, Anthony H. and Warren E Kalbach. Factors in the Adjustment of Immigrants and Their Descendants. Ottawa; Minister of Supply and Services Canada. Census Analytical Study, 1980.

Rose, Ramona Rose. Position and Treatment of Women in Nazi Germany: As Viewed from the Perspective of the English Language Press-1933-1945. Vancouver: Tantalus Research Ltd, 1984.

Ross, Corey. Constructing Socialism at the Grass-Roots: The Transformation of East Germany, 1945-65. New York: St. Martin's Press, 2000.

Scharf, C. Bradley. Politics and Change in East Germany: An Evaluation of Socialist Democracy. Westview Press: Boulder, Colorado, 1984.

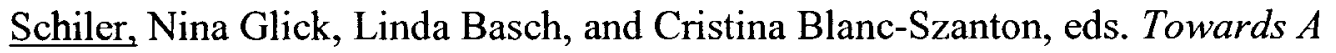
Transnational Perspective on Migration: Race, Class, Ethnicity and Nationalism Reconsidered. Vol 645. New York: New York Academy of Sciences, 1992.

Schoenberg, Hans W. Germans from the East: A Study of Their Migration, Resettlement, and Subsequent Group History Since 1945. The Hague: Nijhoff, 1970.

Shapiro, Laura. Something from the Oven: Reinventing Dinner in 1950 s America. Toronto: Penguin, 2004.

Stadler, Beatrice. Language Maintenance and Assimilation The Case of Selected GermanSpeaking Immigrants in Vancouver, Canada. Vancouver: CAUTG, 1983.

Christine Stansell, City of Women: Sex and Class in New York, 1789-1860. New York: Alfred A. Knopf, 1986.

Steele, Jonathan. Inside East Germany; the State that Came in from the Cold. New York: Urizen Books, 1977.

Stephenson, Jill. Women in Nazi Society. London: Croom Helm, 1975.

Sturhahn, William J.H. They Came From East and West: A History of Immigration to Canada. Winnipeg: North American Baptist Immigration and Colonization Society, 1976.

Summerfield, Penny. Reconstructing Women's Wartime Lives: Discourses and Subjectivity in Oral Histories of the Second World War. Manchester: Manchester University Press, 1998.

Swyripa, Frances. Wedded to the Cause: Ukrainian-Canadian Women and Ethnic Identity, 1891-1991. Toronto, University of Toronto Press, 1993.

Thomas, William I. and Florian Znaniecki. The Polish Peasant in Europe and America. New York: Dover Publications, 1958. 
Thompson, Paul. The Edwardians: The Remaking of British Society. London: Weidenfeld and Nicolson, 1975.

Thompson, Paul. The Voice of the Past: Oral History. Oxford: Oxford University Press, 1988.

Turner Jr., Henry Ashby. The Two Germanies Since 1945. New Haven: Yale University Press, 1987.

Urquhart, M.C. and K.A.H. Buckley, eds. Historical Statistics of Canada. Toronto: MacMillan, 1965, reprint 1971.

Whitaker, Reg. Double Standard: The Secret History of Canadian Immigration. Toronto: Lester \& Orpen Dennys, 1987.

White, Richard. Remembering Ahanagran. New York: Hill and Wang, 1998.

Wieden, Fritz. The Trans-Canada Alliance of German Canadians: A Study in Culture. Windsor: Tolle Lege Enterprises, 1985.

Mark Wyman, DP Europe's Displaced Persons, 1945-51. Toronto: Associated University Press, 1989.

Yow, Valerie Raleigh. Recording Oral History: A Practical Guide for Social Scientists. London: Sage Publications, 1994. 